Красинский Владислав Вячеславович

\title{
ОРГАНИЗОВАННАЯ ПРЕСТУПНОСТЬ НА ВЫБОРАХ И В РОССИЙСКИХ ОРГАНАХ ВЛАСТИ
}

\author{
Монография
}

МОСКВА 2014 
Красинский Владислав Вячеславович - аналитик, эксперт по проблемам криминологии, терроризма и национальной безопасности, ученый - юрист. Доктор юридических наук, полковник, член Общественного научнометодического консультативного Совета при ЦИК России

Рецезенты:

Дамаскин О.В., доктор юридических наук, профессор, Заслуженный юрист Российской Федерации

Керимов А.Д., доктор юридических наук, профессор

K 78 Красинский В.В. Организованная преступность на выборах и в российских органах власти: монография. М.: Юрлитинформ, 2014.

ISBN 978-5-4396-0589-7

В монографии рассматриваются актуальные проблемы участия представителей организованной преступности в формировании и функционировании органов власти и управления в Российской Федерации, предпринимаемые государством меры по противодействию криминализации органов публичной власти в Российской Федерации, предложения по совершенствованию антикриминальной и антикоррупционной политики. Книга предназначена для государственных служащих, сотрудников правоохранительных органов, преподавателей и аспирантов юридических вузов и факультетов, представителей политических партий, СМИ и правозащитных организаций.

@ В.В. Красинский

@ Издательство «Юрлитинформ» 


\section{СОДЕРЖАНИЕ}

ВВЕДЕНИЕ ............................................... 4

1 РОЛЬ И МЕСТО ПРЕСТУПНЫХ ОРГАНИЗАЦИЙ (СООБЩЕСТВ) В ПОЛИТИЧЕСКОЙ СИСТЕМЕ РОССИЙСКОГО 10 ОБЩЕСТВА.....................................................

2 ПАРТИЙНЫЕ СПИСКИ НА ВЫБОРАХ В ГОСУДАРСТВЕННУЮ ДУМУ ФЕДЕРАЛЬНОГО СОБРАНИЯ РОССИЙСКОЙ ФЕДЕРАЦИИ ШЕСТОГО СОЗЫВА: КАНДИДАТЫ С УГОЛОВНЫМ ПРОШЛЫМ И АНТИКРИМИНАЛЬНАЯ ПОЛИТИКА ГОСУДАРСТВА

3 МУНИЦИПАЛЬНЫЕ И РЕГИОНАЛЬНЫЕ ВЫБОРЫ В КОНТЕКСТЕ УСТРЕМЛЕНИЙ ПРЕСТУПНЫХ ОРГАНИЗАЦИЙ (СООБЩЕСТВ)

4 ОСНОВНЫЕ НАПРАВЛЕНИЯ ПРОТИВОДЕЙСТВИЯ КРИМИНАЛИЗАЦИИ ОРГАНОВ ПУБЛИЧНОЙ ВЛАСТИ В 65 РОССИЙСКОЙ ФЕДЕРАЦИИ.

5 МЕЖДУНАРОДНО-ПРАВОВЫЕ ОСНОВЫ И ЗАРУБЕЖНЫЙ ОПЫТ ПРОТИВОДЕЙСТВИЯ КРИМИНАЛИЗАЦИИ ОРГАНОВ ПУБЛИЧНОЙ ВЛАСТИ........................................

ПРЕДЛОЖЕНИЯ ПО СОВЕРШЕНСТВОВАНИЮ ОТДЕЛЬНЫХ ЗАКОНОДАТЕЛЬНЫХ АКТОВ РОССИЙСКОЙ ФЕДЕРАЦИИ В РАМКАХ ПРОТИВОДЕЙСТВИЯ КРИМИНАЛИЗАЦИИ ОРГАНОВ ПУБЛИЧНОЙ ВЛАСТИ.

ЗАКЛЮЧЕНИЕ............................................. 219

ЛИТЕРАТУРА ................................................. 236

ПРИЛОЖЕНИЯ ................................................ 247 


\section{Светлой памяти Артюшиной Ларисы Иосифовны посвящается}

\section{ВВЕДЕНИЕ}

Одну из главных угроз для безопасности России в настоящее время представляет сращивание криминальных структур с органами государственной и муниципальной власти в Российской Федерации, их притязания на участие в политике и получение доступа к управлению государством и регионами. Организованная преступность стремится расширять сферы своего влияния и для этого пытается активно использовать процесс организации и проведения выборов. Поэтому в ходе государственного контроля за соблюдением законности избирательного процесса, защиты политических прав граждан Российской Федерации, привлечения к юридической ответственности за нарушение конституционных прав участников выборов актуальной проблемой становится противодействие органов управления, избирательных комиссий и правоохранительных структур проникновению криминалитета в органы государственной власти и местного самоуправления.

Кандидаты, связанные с организованной преступностью, а также лица, ранее осужденные за тяжкие преступления, участвуют в выборах депутатов Государственной Думы Федерального Собрания Российской Федерации и законодательных органов государственной власти субъектов Российской Федерации. Такие факты отмечались в Кабардино-Балкарской Республике, Республике Тыва, Алтайском, Краснодарском, Приморском и Хабаровском краях, Архангельской, Камчатской, Магаданской, Московской, Мурманской, Новосибирской, Омской, Оренбургской, Пензенской, Пермской, Ростовской, 
Рязанской, Самарской, Саратовской, Свердловской, Тамбовской, Томской, Челябинской областях, городах Москве и Санкт-Петербурге и др ${ }^{1}$

По данным проведенного Фондом «Общественное мнение» Всероссийского опроса городского и сельского населения 44 субъектов Российской Федерации, 76 \% опрошенных граждан утверждают, что в органах власти региона, в котором они проживают, присутствуют представители криминального мира, лица, связанные с организованной преступностью. 63 \% респондентов заявляют, что таких примеров достаточно много ${ }^{2}$.

Многим кажется, что сегодня в региональных органах власти стало больше представителей криминалитета, чем в 90 -е годы (14\% считают, что доля криминала во власти осталась прежней, 10\% - что она уменьшилась).

70\% респондентов утверждают, что в их регионах представители криминального мира баллотируются на различные выборные посты в органы власти, причем 56\% полагают, что это происходит довольно часто 3 .

Яркими примерами личного участия известных представителей организованной преступности в федеральных и региональных выборах являются выдвижение кандидатуры лидера преступного сообщества «Уралмаш» А. Хабарова на выборах депутатов Государственной Думы Федерального Собрания Российской Федерации и избрание его в Законодательное Собрание Свердловской области, получение депутатского мандата Тульской областной Думы криминальным лидером Н. Новиковым, избрание депутатом Законодательного Собрания Красноярского края А.Быкова.

${ }^{1}$ Справка Генеральной прокуратуры Российской Федерации к координационному совещанию руководителей правоохранительных органов Российской Федерации от 28 июля 1999 года «О механизме информационного обеспечения режима законности в период предвыборных кампаний». С.2.

2 Фонд «Общественное мнение». Всероссийский опрос городского и сельского населения в 100 населенных пунктах 44 областей и республик всех экономикогеографических зон. Метод опроса - интервью по месту жительства. Статистическая погрешность не превышает 3,6\%. 24 июня 2004 г. 1500 респондентов. См. Петрова А. Криминал во власти - обычное явление? //bd.fom.ru/report/map/projects.

${ }^{3}$ Полунин А. «Братки» собрались во власть // Труд. 2004. 10 августа. 
В 1995 г. в борьбе за депутатские мандаты Государственной Думы Федерального Собрания Российской Федерации участвовали 87 ранее судимых или находящихся под следствием претендентов. В ходе федеральной избирательной кампании 1999 г. органами МВД, ФСБ и Центризбиркомом России были выявлены и раскрыты уже сотни таких случаев ${ }^{1}$. По материалам органов безопасности было отведено более 50 кандидатов в депутаты, имевших криминальное прошлое 2 .

Только в одной избирательной кампании по выборам депутатов Законодательного Собрания Новосибирской области в 1998 г. участвовали 10 ранее судимых граждан, в т.ч. известные лидеры преступных сообществ ${ }^{3}$.

Многочисленные факты выдвижения и регистрации кандидатов с уголовным прошлым были зафиксированы в ходе выборов в органы государственной власти субъектов Российской Федерации 8 сентября 2013 г.

Наибольшее количество зарегистрированных кандидатов, представляющих интересы криминальных структур, было отмечено на выборах депутатов Государственного Собрания - Курултая Республики Башкортостан - 13.

11 ранее судимых кандидатов баллотировалось на выборах депутатов Законодательного Собрания Забайкальского края и выборах депутатов Законодательного Собрания Владимирской области.

10 ранее судимых кандидатов участвовало в выборах народных депутатов Республики Саха, 8 - на выборах депутатов Народного Хурала Республики Бурятия, 7 - на выборах в Законодательное Собрание Ростовской области.

Исключительная ситуация сложилась в Республике Марий Эл после избрания в январе 1997 г. на пост Президента Республики В.А. Кислицына, в отношении которого органами внутренних дел возбуждалось свыше 5

1 Злотникова E.B. Влияние организованной преступности на политическую безопасность Российской Федерации. Автореф. ...канд. полит. наук. М., 2011.

${ }^{2}$ Мохов E.A. Организованная преступность и национальная безопасность России. М.: Вузовская книга, 2006. С. 46.

${ }^{3}$ Мохов Е.A. Там же. С. 29. 
уголовных дел по хозяйственным преступлениям, предусмотренным различными статьями УК РСФСР. В результате руководящие должности в администрации Президента и Правительстве Республики заняли неоднократно привлекавшиеся к уголовной ответственности: В.Н. Смирнов министр Правительства Республики и Р.И. Репин - первый заместитель Главы Правительства Республики ${ }^{1}$.

Наиболее привлекательным для представителей криминалитета остается муниципальный уровень выборов, где устремления преступных организаций (сообществ) направлены на замещение должностей глав местного самоуправления и получение депутатских мандатов в представительных органах муниципальных образований. Так, широкую огласку приобрело избрание на пост мэра г. Ленинска-Кузнецкого Кемеровской области трижды судимого Г.В. Коняхина, избрание мэром г. Нижний Новгород дважды судимого А.А. Климентьева.

На муниципальных выборах 8 сентября 2013 г. в списках кандидатов в Екатеринбургскую городскую Думу было зафиксировано 7 граждан, имеющих уголовное прошлое, в Волгоградскую городскую Думу баллотировалось 5 ранее судимых кандидатов.

В связи с резонансными уголовными делами на Кубани следуют упомянуть депутата по Раздольненскому избирательному округу С.Ю. Цеповяза и депутата Совета муниципального образования Кущевского района С. В. Цапка.

Формирование и функционирование органов власти, которые покровительствуют организованной преступности, наносят ущерб экономике, ущемляют конституционные права и свободы граждан, способствуют росту социальной напряженности, дискредитирует институты государственной власти и разочаровывает население в демократических ценностях.

${ }^{1}$ Кокоткин $A$. Кислый, Репа и другие официальные лица // Совершенно секретно. 1998. № 8. Цит. по Мохов E.A. ФСБ: борьба с организованной преступностью. М.: Вузовская книга, 2006. С. 37. 
Существующая криминогенная ситуация усугубляется проводимой в Российской Федерации уголовно-правовой политикой. Современное состояние уголовно-правового законотворчества характеризуется хаотичным и противоречивым подходом к попыткам противодействия преступности.

В законотворчестве доминируют тенденции: освобождения от уголовной ответственности лиц за совершение широкомасштабных экономических преступлений; отказа от реальной борьбы с незаконным обогащением путем конфискации; введения системы денежных штрафов, позволяющей пользоваться ею состоятельным гражданам, для освобождения от реального наказания в форме лишения свободы; имитации сокращения преступности путем декриминализации общественно опасных деяний и др. Это означает выстраивание дискриминационной социальной системы в уголовно-правовой сфере на основе неравенства материальных возможностей граждан ${ }^{1}$.

Проблема криминализации органов власти и осуществления антикриминальной политики государства приобретает особую значимость в связи с развитием деструктивных процессов в социально-экономической и общественно-политической сферах (монополизация политической власти, партийная коррупция, протестная активность населения, обострение межнациональных и межконфессиональных отношений, деградация и дискредитация властных институтов и др.), а также необходимостью выработки предложений по их нейтрализации.

С учетом этого в данной работе предпринята попытка выявить и раскрыть роль и место преступных организаций (сообществ) в политической системе российского общества, исследовать избирательные кампании по выборам депутатов Государственной Думы Федерального Собрания Российской Федерации, региональные и муниципальные выборы в контексте устремлений криминальных структур, обосновать основные направления

1 Дамаскин О.B. Криминологические аспекты формирования современной уголовно-правовой политики // Современное право. 2013. № 5. 
противодействия государственных и муниципальных органов криминализации публичной власти в Российской Федерации, сформулировать предложения по совершенствованию законодательных актов Российской Федерации в сфере противодействия криминализации органов публичной власти. 


\section{1. РОЛЬ И МЕСТО ПРЕСТУПНЫХ ОРГАНИЗАЦИЙ (СООБЩЕСТВ) В ПОЛИТИЧЕСКОЙ СИСТЕМЕ РОССИЙСКОГО ОБЩЕСТВА}

Криминализация российского общества справедливо рассматривается ведущими российскими юристами в качестве угрозы конституционному строю. По словам Председателя Конституционного Суда Российской Федерации В. Зорькина, «с каждым днем становится все очевиднее, что сращивание власти и криминала по модели, которую сейчас называют «кущевской», - не уникально. Что то же самое (или нечто сходное) происходило и в других местах - в Новосибирске, Энгельсе, ГусьХрустальном, Березовске и так далее... Криминал подрывает основы нашей хрупкой правовой системы, основы нашей социальной, политической и экономической жизни. Он посягает на все социальные скрепы. Он разлагает ткань нашего весьма незрелого гражданского общества. А порою и выступает в качестве соискателя на роль социального начала, подменяющего собой гражданское общество. Криминал подрывает основы общественного благополучия и стабильности. И, конечно же, он превращается в основное препятствие на пути общественного развития» ${ }^{1}$.

Рост активности организованных преступных организаций (сообществ), связанный с попытками избрания в органы государственной власти и органы местного самоуправления, обусловлен заинтересованностью преступных организаций в постоянном наращивании своих доходов, прямой зависимостью официальной и теневой экономической деятельности от политической конъюнктуры в Российской Федерации, желанием руководителей и участников криминальных структур обеспечить личную безопасность ${ }^{2}$.

\footnotetext{
${ }^{1}$ Зорькин В. Конституция против криминала // Рос. газ. 2010. 10 декабря.

2 Красинский В.В. Правовое обеспечение защиты конституционного строя России в избирательном процессе: Монография. М.: Новый индекс, 2010. С. 42.
} 
Для представителей криминалитета избрание на выборную должность и получение депутатского мандата представляются исключительно значимыми.

Во-первых, факт наделения бандитов властными полномочиями легализует их криминальное прошлое и ставит под сомнение связи с преступными сообществами (организациями).

Во-вторых, замещение выборных публичных должностей и принадлежность к органам народного представительства создают видимость реализации бандитами властных полномочий от имени и по поручению народа.

В-третьих, официальное задействование материальных, финансовых, информационных, юридических и иных ресурсов государства заметно расширяет сферы и силу воздействия преступных сообществ (организаций) на общественные процессы внутри страны и за ее пределами.

Социальной базой обновленных преступных организаций становится поколение конца 80-х годов XX века, мировоззрение которого формировалось на уголовной субкультуре, антиобщественных нормах и героизации представителей криминалитета в средствах массовой информации. В связи с расширением полномочий органов местного самоуправления по вопросам земельных отношений (проведение землеустроительных работ, переоформление прав на землю, утверждение правил землепользования и застройки, распоряжение земельными участками) наиболее привлекательным сегментом трудоустройства кандидатов, представляющих интересы криминалитета, являются выборные муниципальные должности и представительные органы местного самоуправления.

Для проникновения в органы власти криминальными элементами используется смена фамилий, удаление своих персональных данных из региональных баз правоохранительных органов, а также продвижение «незасвеченных» ставленников (нередко близких родственников), не 
имеющих судимостей и выявленных связей с организованной преступностью.

Изучение состава организованных преступных групп указывает на заметное участие в них бывших военнослужащих и сотрудников специальных служб, сращивание их с правоохранительными органами ${ }^{1}$.

В ряде субъектов Российской Федерации материалы оперативносправочных учетов информационных центров МВД, ГУВД, УВД субъектов Российской Федерации сознательно искажаются коррумпированными сотрудниками правоохранительных органов, в полиции и судебной системе проходят службу амнистированные участники незаконных вооруженных формирований и лица, в отношении которых уголовное преследование было прекращено за истечением срока давности и примирением сторон.

Анализ материалов избирательных кампаний свидетельствует, что все политические партии (и их региональные отделения) включали и продолжают включать в свои списки кандидатов из числа представителей криминалитета.

Потенциал организованных преступных групп активно используется на всех стадиях избирательного процесса.

На этапе выдвижения преступные организации на возмездной основе включают своих кандидатов в списки избирательных объединений и осуществляют угрозы в адрес кандидатов - конкурентов. В нападениях на активистов партий принимают участие ранее судимые за тяжкие преступления граждане. В ходе предвыборной агитации криминальные агитаторы осуществляют подкуп избирателей, распространяют подложные и анонимные агитационные материалы, допускают иные нарушения законодательства о выборах.

Так, 15 сентября 2010 г. ОМОН Республики Тыва «сорвал» встречу избирателей с представителями регионального отделения политической

1 Дамаскин О.B. Российская Армия в современном обществе: проблемы и перспективы. М.: Юрлитинформ, 2011. С. 207. 
партии «Справедливая Россия» в буддийском монастыре Устуу-Хурээ. 6 кандидатов в Верховный Хурал Тувы приехали по приглашению настоятеля для проведения обряда благоденствия, призванного обеспечить победу партии на выборах. После обряда была запланирована «встреча» с избирателями.

В 15.30 в дежурную часть ОВД по Дзун-Хемчикскому району поступил звонок от неизвестного о том, что на территории храма Устуу-Хурээ проводится сбор лиц, ранее привлекавшихся к уголовной ответственности. По итогам проверки в райотдел были доставлены 42 человека для установления личности. В отношении 5 из них составлен протокол об административном правонарушении по статье 20.1 КОАП за оказание сопротивления при задержании. У одного из граждан изъято вещество с характерным запахом дикорастущей конопли. После разбирательства все задержанные были отпущены. Откуда в храме оказалось 42 ранее судимых человека, в МВД Республики Тыва пояснить не смогли ${ }^{1}$.

Криминальные структуры осуществляют скрытое и легальное финансирование избирательных кампаний отдельных кандидатов и избирательных объединений, в результате чего выборы превращаются в процедуру «купли-продажи» власти².

Примером может служить уголовное дело в отношении депутата Государственной Думы Федерального Собрания Российской Федерации В.И. Головлева. В.И. Головлев, будучи заместителем главы администрации Челябинской области, незаконно провел приватизацию ряда государственных предприятий области в интересах конкретных хозяйствующих субъектов, за что в последующем, после выдвижения его кандидатом в депутаты Государственной Думы Федерального Собрания Российской Федерации руководителями этих хозяйствующих субъектов C. 102 .

${ }^{1}$ Выборы в России 10 октября 2010 года. Аналитический доклад. М.: Голос, 2010.

2 По оценкам специалистов, преступные сообщества тратят до 50 \% получаемой прибыли на продвижение своих ставленников в органы законодательной и исполнительной власти. 
были перечислены денежные средства в размере 97 миллионов рублей в его избирательный фонд ${ }^{1}$. Другим примером коррупции в избирательном процессе является уголовное дело в отношении 14 депутатов Тверской городской Думы во главе с ее бывшим председателем В. Почтаревым. Указанная группа «народных представителей» отрабатывала деньги финансовых спонсоров их избирательной кампании путем принятия противоправных нормативных актов ${ }^{2}$.

В 1995 г. организованное преступное сообщество «Уралмаш» оказало финансовую поддержку и иным образом активно содействовало избранию одного из претендентов на должность губернатора Свердловской области.

Между тем, информация о связях с криминалом может использоваться для дискредитации кандидатов-соперников или отказов в регистрации кандидатов. Например, в ходе выборов 13 марта 2011 г. кандидату в депутаты Совета народных депутатов г. Владимира двадцать шестого созыва по одномандатному избирательному округу № 10 г. Мартынову В.Н. (якобы «в криминальных кругах - Мартын»), были приписаны 6 статей УК РФ, хотя на сайте избирательной комиссии в сведения о наличии у кандидата неснятых и непогашенных судимостей не подтвердились.

В ходе избирательной кампании, назначенной на 10 октября 2010 г., в Самарской области было отказано в регистрации кандидату А. Деминой, на протяжении четырех созывов являвшейся депутатом Самарской губернской Думы, на основании того, что в подписных листах не были указаны сведения об отсутствии у нее судимости ${ }^{3}$.

1 Цит. по Кабанов П.А., Райков Г.И., Чирков Д.К. Политическая коррупция в условиях реформирования российской государственности на рубеже веков: Монография. М.: Дружба народов, 2008. С. 63. Данное уголовное дело было прекращено в связи с убийством В.И. Головлева неустановленными лицами.

${ }^{2}$ Андриянов О., Иванова T. Тверская застава // Рос. газ. 2007. 25 августа; Никитина M. Коррупционная дюжина // Рос. газ. 2007. 7 декабря.

В соответствии с пунктом 9 статьи 37 Федерального закона «Об основных гарантиях избирательных прав и права на участие в референдуме граждан Российской Федерации» сведения о судимости подлежат указанию в подписном листе исключительно в случае еe наличия у кандидата. Сведения об отсутствии судимости не подлежат указанию, поэтому отказ в регистрации на таком основании нельзя признать законным. См. Аналитический обзор по результатам мониторинга региональных и муниципальных 
Приведенные примеры свидетельствуют об актуальности проблемы криминализации политической системы российского общества и необходимости адекватного противодействия попыткам проникновения преступных организаций (сообществ) в органы государственной власти и местного самоуправления.

Как отмечают отечественные исследователи, «непосредственное воздействие преступных сообществ на политико-правовые процессы в российском обществе свидетельствует в пользу их признания в качестве самостоятельного компонента политической системы Российской Федерации» ${ }^{1}$.

По мнению В.М. Сырых, «в настоящее время организованная преступность в Российской Федерации является общеизвестным и бесспорно установленным фактом, с которым должны считаться как государство, так и юридическая наука. В соответствие с реалиями современной жизни надлежит привести и теоретические представления о политической системе Российской Федерации, дополнив ее таким специфическим, но действенным компонентом, как преступные сообщества»².

Другой позиции придерживается О.В. Мартышин: «Элементами политической системы являются именно легальные, не запрещенные законом организации, деятельность которых не направлена на разрушение господствующей системы. ... Нельзя считать элементом политической системы организации, стремящиеся свергнуть существующий строй, разрушить господствующую политическую систему и установить новую» ${ }^{3}$.

Аргументация О.В Мартышина представляется дискуссионной, поскольку подавляющее большинство преступных организаций (сообществ)

выборов 10 октября 2010 г. М.: Ассоциация некоммерческих организаций по защите избирательных прав «Гражданский контроль». С. 2.

1 Cырых B.M. Теория государства и права: Учебник. - М.: Юридический Дом «Юстицинформ», 2001. С.430.

2 Теория государства и права: Учебник / Под ред. В.К. Бабаева. М.: Юрист, 2007. С. 140.

${ }^{3}$ Теория государства и права: Учебник / Под ред. О.В. Мартышина. М.: Норма, 2007. C. 183 . 
не преследует экстремистских целей - насильственного свержения конституционного строя и разрушения господствующей политической системы. Криминальные структуры, напротив, стремятся использовать существующий государственный механизм и муниципальный аппарат в своих интересах, максимально оперативно и органично легализовать свой статус в политической системе.

Чтобы отделить преступные организации (сообщества) от иных социальных явлений и институтов политической системы, проведем терминологический анализ рассматриваемой предметной области.

В соответствии с частью 4 статьи 35 УК РФ преступное сообщество (преступная организация) может осуществлять свою преступную деятельность либо в форме структурированной организованной группы, либо в форме объединения организованных групп, действующих под единым руководством.

Под структурированной организованной группой следует понимать группу лиц, заранее объединившихся для совершения одного или нескольких тяжких либо особо тяжких преступлений, состоящую из подразделений (подгрупп, звеньев и т.п.), характеризующихся стабильностью состава и согласованностью своих действий. Структурированной организованной группе, кроме единого руководства, присущи взаимодействие различных ее подразделений в целях реализации общих преступных намерений, распределение между ними функций, наличие возможной специализации в выполнении конкретных действий при совершении преступления и другие формы обеспечения деятельности преступного сообщества (преступной организации $)^{1}$.

Объединение организованных групп предполагает наличие единого руководства и устойчивых связей между самостоятельно действующими

${ }^{1}$ Пункт 3 Постановления Пленума Верховного Суда Российской Федерации от 10 июня 2010 г. № 2 «О судебной практике рассмотрения уголовных дел об организации преступного сообщества (преступной организации) или участии в нем (ней)» // Рос. газ. 2010. 17 июня. 
организованными группами, совместное планирование и участие в совершении одного или нескольких тяжких или особо тяжких преступлений, совместное выполнение иных действий, связанных с функционированием такого объединения ${ }^{1}$.

Руководство преступным сообществом (организацией) может выражаться: в определении целей, в разработке общих планов деятельности преступного сообщества (преступной организации), в подготовке к совершению конкретных тяжких или особо тяжких преступлений, в распределении ролей между членами сообщества, в организации материально-технического обеспечения, в разработке способов совершения и сокрытия совершенных преступлений, в принятии мер безопасности в отношении членов преступного сообщества, в конспирации и в распределении средств, полученных от преступной деятельности.

Руководитель преступного сообщества разрешает все внутренние конфликты и следит за образом жизни членов группы, требуя от них соблюдения внешне законопослушного поведения в целях обеспечения конспирации и предотвращения разоблачения группы. Он обеспечивает целостность и стабильность состава группы ${ }^{2}$. В.А. Жбанков обращает внимание на существование системы региональных и межрегиональных связей, направленных на расширение организованной преступной деятельности ${ }^{3}$.

К функциям руководителя преступного сообщества (преступной организации) следует также относить принятие решений и дачу соответствующих указаний участникам преступного сообщества (преступной организации) по вопросам, связанным с распределением доходов,

1 Пункт 5 Постановления Пленума Верховного Суда Российской Федерации от 10 июня 2010 г. № 2.

2 Вольнский В.А., Тишутина И.В. Раскрытие и расследование бандитизма первоначальный этап. М.: МосУ МВД России, Книжный мир, 2005. С.6.

3 Жбанков В.А. К вопросу изучения личности руководителей организованных преступных формирований / Проблемы технико-криминалистического раскрытия и расследования преступлений: Мат. науч.-практ. конф. М.: МЮИ МВД России, 1997. С. 137-139. 
полученных от преступной деятельности, с легализацией (отмыванием) денежных средств, добытых преступным путем, с вербовкой новых участников, с внедрением членов преступного сообщества (преступной организации) в государственные, в том числе правоохранительные, органы ${ }^{1}$.

Анализ судебно-следственной практики показывает, что распределение ролей между членами преступного сообщества (организации) предполагает квалифицированное осуществление согласованной с руководством преступного сообщества профессиональной деятельности в рамках:

- планирования преступной деятельности и «наводки» (подбора объектов криминальной заинтересованности и добывания первичной информации о них);

- оперативного сопровождения функционирования и обеспечения собственной безопасности преступного сообщества (уголовная разведка и контрразведка);

- боевого сопровождения преступной деятельности (отдельных силовых акций);

- финансового и материально-технического обеспечения преступной деятельности (распределение преступных доходов и легализация денежных средств; обеспечение жильем, транспортом, оружием, средствами связи и др.);

- правового обеспечения подконтрольных криминальным структурам организаций и предприятий, юридической защиты членов преступного сообщества - фигурантов уголовных дел;

- административного, информационного и политического прикрытия организованной преступной деятельности.

По мнению В.М. Сырых, от легально действующих общественных объединений преступное сообщество отличается двумя признаками²:

${ }^{1}$ Там же. Пункт 10

2 Теория государства и права: Учебник / Под ред. В.К. Бабаева. М.: Юрист, 2007. С. 141. Необходимо сделать важную оговорку, связанную с тем, что в настоящее время преступные сообщества (организации) частично легализовались в политической системе 
1) оно действует нелегально (организация и деятельность прямо запрещены законом);

2) сообщество ставит своей целью совершение тяжких или особо тяжких преступлений типа захвата власти неконституционным путем, пропаганды национальной или религиозной розни, совершения хищений имущества в больших размерах, совершения заказных убийств и др.

В зависимости от сферы противоправных посягательств преступные сообщества подразделяются В.М. Сырых на уголовные и политические ${ }^{1}$.

Интересы уголовных преступных сообществ остаются преимущественно в экономической сфере. Такие сообщества, как правило, не поднимаются до уровня политической деятельности и не ставят своей непосредственной целью воспрепятствование деятельности государства, его органов, смену власти или политического режима. Политические преступные сообщества, наоборот, ставят своей непосредственной целью захват власти неконституционным вооруженным путем, организацию мятежей, а также совершение действий, препятствующих нормальной деятельности государства, его органов и должностных лиц.

Такая классификация преступных сообществ нуждается в корректировке. В настоящее время практически не осталось «чистых» уголовных или политических преступных сообществ. Любое преступное сообщество заинтересовано в стабильном финансировании, прочной экономической базе и надежном (легальном) административно-политическом прикрытии. Поэтому в деятельности подавляющего большинства преступных организаций (сообществ) проявляется политический аспект в виде стремления к завоеванию (удержанию, использованию) государственной власти, связанного с последующей переориентацией государственных и муниципальных политических институтов на постоянное обслуживание криминальных интересов.

российского общества и располагают разветвленной сетью открыто действующих управленческих структур, общественных организаций и хозяйствующих субъектов.

${ }^{1}$ Там же. С. 142. 
Анализ места и роли преступных организаций (сообществ) в политической системе общества следует проводить с учетом требований (критериев), предъявляемых ко всем институтам политической системы.

В соответствии с положениями теории государства институты политической системы общества должны отвечать двум основным критериям: организационному и политическому ${ }^{1}$.

Организационный критерий означает внутреннюю упорядоченность и оформленность элемента (наличие специфических задач, функций, иерархия, автономность), а политический критерий предполагает политический характер деятельности элемента, которая раскрывается в нескольких аспектах:

a) способность выражать политические интересы определенной социальной группы;

б) способность участвовать в политической жизни, т.е. иметь непосредственное или опосредованное отношение к завоеванию, удержанию или использованию государственной власти;

в) способность следовать в своей деятельности определенной политической программе и руководствоваться политическими нормами.

Современные преступные организации (сообщества), действующие на территории Российской Федерации, соответствуют названным критериям.

К числу специфических задач преступных организаций (сообществ) по участию в политической системе следует отнести:

- замещение выборных и назначаемых должностей с целью последующего использования должностных полномочий в интересах преступных организаций (сообществ);

- формирование в федеральных и региональных органах государственной власти депутатского корпуса, лоббирующего принятие

${ }^{1}$ Существуют различные точки зрения в отношении количества критериев отбора элементов институциональной подсистемы политической системы (политической организации) общества. Так, Ф.М. Бурлацкий и В.Е. Чиркин предлагают семь таких критериев, В.Н. Жуков, С.А. Комаров и М.Н. Марченко - три. Несмотря на многообразие мнений, все авторы признают наличие организационного и политического критериев. 
нормативных правовых актов, политических, административных и иных официальных решений в интересах преступных организаций (сообществ);

- приобретение иммунитетов выборных должностных лиц и депутатской неприкосновенности.

Названные политические задачи преступных организаций (сообществ), участвующих в политической системе, неразрывно связаны с экономическими:

- легальный передел рынков сырья, недвижимости, товаров и услуг в интересах организованных преступных групп;

- установление контроля над прибыльными бюджетообразующими предприятиям и высокорентабельными отраслями экономики (строительство, топливно-энергетический комплекс, добывающая промышленность, учреждения кредитно-финансовой сферы);

- неправомерное получение дополнительных льгот и преференций (экспортно-импортные операции, налоги, лицензионная деятельность, квотирование)

- неправомерное получение кредитов и управление бюджетными средствами в интересах преступных организаций (сообществ).

Решению преступными сообществами своих экономических задач способствует зависимость судебной системы от федеральных и региональных органов исполнительной власти, которая в сочетании с выборочным правоприменением позволяет криминальным лидерам осуществлять рейдерские захваты имущественных комплексов, проводить «недружественные поглощения» интересующих хозяйствующих субъектов, использовать процедуру банкротства конкретных предприятий в интересах преступных организаций.

По данным МВД России, в 2, 7 тыс. уголовных дел по экономическим составам, расследованных органами внутренних дел в январе-марте 2013 г., была установлена причастность организованных групп и преступных сообществ. 
Одной из наиболее криминализированных остается сфера финансовокредитных отношений, в которой выявлено более 19,5 тыс. квалифицированных преступлений ${ }^{1}$.

Преступные сообщества стремятся «сопровождать» даже реализацию приоритетных национальных проектов. Так, в 2012-2013 г. имели место крупные хищения средств государственных кампаний, предназначенных для инвестирования в развитие ЖКХ, промышленности, транспортной инфраструктуры. В ходе прокурорских проверок установлены факты хищений денежных средств, выделенных из Фонда содействия реформированию ЖКХ и предназначенных для проведения капитального ремонта многоквартирных домов. Выявляются случаи перечисления денежных средств на счета аффилированных коммерческих структур и привлечения к выполнению работ организаций-посредников, имеющих признаки фирм-однодневок. В деятельности управляющих компаний и коммунальных организаций распространены криминальные посягательства на денежные средства, уплаченные гражданами за жилищно-коммунальные услуги. В целом за 2010 г. органами прокуратуры в сфере ЖКХ выявлено более 130 тыс. нарушений законов. Правоохранительными органами по материалам, направленным прокурорами, возбуждено 200 уголовных дел 2 .

Надзорная практика Генеральной прокуратуры Российской Федерации показывает, что сферами повышенного коррупционного риска являются расходование бюджетных средств, осуществление государственных закупок и федеральных программ, размещение заказов на поставки товаров, выполнение работ и оказание услуг для государственных и муниципальных нужд³. Прокурорами выявляется значительное количество нарушений

1 Состояние преступности и основные результаты оперативно-служебной деятельности органов внутренних дел за январь-март 2013 г. / ОАД МВД России. С. 5.

${ }^{2}$ Субанова H.B. Прокурорский надзор как средство укрепления законности в сфере экономики // Журнал российского права. 2012. № 1.

3 Материалы заседания Коллегии Генеральной прокуратуры Российской Федерации об итогах деятельности органов прокуратуры по обеспечению законности и правопорядка в первом полугодии 2013 г. и определению задач по совершенствованию 
законов при исполнении доходных и расходных частей бюджетов, в том числе нецелевое использование бюджетных средств. Как отметил Президент Российской Федерации, нецелевые расходы, включая прямое воровство и «откаты», составляют не менее триллиона рублей ${ }^{1}$.

Наблюдается устойчивая тенденция к росту числа выявляемых нарушений на всех этапах закупочной деятельности (особенно при размещении заказа). Так, по результатам проверок, проведенных органами прокуратуры в 2008 г., выявлено более 14 тыс. коррупционных нарушений законов о размещении заказов на поставки товаров, выполнение работ, оказание услуг для государственных и муниципальных нужд; в 2009 г. почти 20 тыс.; в 2010 г. - более 32 тыс. Неправомерная деятельность недобросовестных представителей государственных заказчиков и предпринимателей создает реальную угрозу национальной безопасности, подрывает авторитет власти, препятствует конкуренции и сдерживает социально-экономическое развитие страны ${ }^{2}$.

Несмотря на предпринимаемые правоохранительными органами меры, криминогенная обстановка в Российской Федерации продолжает оставаться напряженной. Так, в 17 регионах России выросло число тяжких и особо тяжких преступлений. В январе-марте 2013 г. раскрыто почти 6 тыс. преступлений, совершенных организованными группами или преступными сообществами. Особую опасность для общества представляют организованные формы преступности, связанные с бандитизмом, терроризмом, экстремизмом, а также незаконным оборотом наркотиков и оружия. Пресечена деятельность 23 тыс. лидеров и активных участников организованных групп. Зарегистрировано 68 преступлений, связанных с организацией преступного сообщества или участием в нем.

Согласно статистическим данным в 2012 году зарегистрировано 49513

прокурорской практики во втором полугодии 2013 г. URL // http://genproc.gov.ru/smi/news/genproc/news-83866 (дата обращения: 19 августа 2013 г.).

1 Послание Президента Российской Федерации Федеральному Собранию Российской Федерации от 30 ноября 2010 г. // Рос. газ. 2010. 1 декабря.

${ }^{2}$ Субанова Н.В. Прокурорский надзор как средство укрепления законности в сфере экономики // Журнал российского права. 2012. № 1 . 
преступлений коррупционной направленности. Большинство из них $(90,1 \%)$, выявлено органами внутренних дел. Удельный вес преступлений коррупционной направленности в структуре преступности в Российской Федерации составляет 2,2\%. В то же время доля ущерба от коррупционных преступлений достигает 7,8\% (20 821800000 руб.) из суммы ущерба от всей выявленной в стране преступности. Из числа преступлений коррупционной направленности, дела и материалы о которых находились в производстве в отчетный период, 75,8\% (37 546) направлено в суд.

В 2012 году было выявлено 13565 лиц, совершивших преступления коррупционной направленности ${ }^{1}$.

Как свидетельствуют материалы уголовной статистики, на основе коррупционной составляющей организованная преступная деятельность осуществляется при участии должностных лиц правоохранительных органов, сотрудничающих с криминальными структурами ${ }^{2}$. При этом, если ранее наиболее высокодоходные сферы незаконной деятельности находились под негласным контролем криминальных авторитетов, то в настоящее время наметилась тенденция к реализации преступных (в том числе коррупционных) схем руководителями крупных коммерческих организаций и должностными лицами органов государственной власти и управления.

Анализ структуры коррупционной преступности показывает рост удельного веса мошенничеств, совершенных с использованием служебного положения (с 23\% в 2011 г. до 31\% в 2012 г.). Из лиц, привлеченных к ответственности за совершение преступлений коррупционной направленности, большинство работали в исполнительных органах

1 Статистические данные ГИАЦ МВД России - «Сводный отчет по России о состоянии преступности и результатах расследования преступлений» (форма 494); «Сводный отчет по России о результатах работы правоохранительных (правоприменительных) органов по борьбе с преступлениями, совершенными с использованием служебного положения должностными лицами, государственными служащими и служащими органов местного самоуправления, а также лицами, выполняющими управленческие функции в коммерческой или иной организации» (форма 590); статистические сведения управления правовой статистики Генеральной прокуратуры Российской Федерации - «Сведения о работе прокурора по надзору за исполнением законодательства о противодействии коррупции и о результатах расследования уголовных дел о преступлениях коррупционной направленности» (форма К) за 2012 г. и аналогичные формы за 2008-2011 гг.

2 Вызывает тревогу тот факт, что преступными группами иногда руководят лица начальствующего состава правоохранительных органов (Республика Ингушетия, Тульская область). 
государственной власти на уровне субъекта Федерации - 57\%; в органах местного самоуправления работали - 21,6\%, в органах государственной власти федерального уровня - 21,5\%. Среди работников правоохранительных органов, привлеченных к уголовной ответственности за коррупционные преступления, подавляющее большинство (63\%) являлись сотрудниками органов внутренних дел ${ }^{1}$.

Следует констатировать, что к ответственности за коррупционные преступления привлекаются в основном представители низовых звеньев государственного аппарата и органов местного самоуправления. Удельный вес представителей органов государственной власти и управления среди осужденных взяткополучателей составляет менее 1 \%. Доля фактов взяточничества в крупном размере в общем числе выявленных - лишь 7,6\% .

Как свидетельствует статистика МВД России, 47,4\% раскрытых за январь-март 2013 г. преступлений совершены лицами, ранее нарушавшими закон (152,6 тыс.), в т.ч. 108,5 тыс. - ранее судимыми. Свыше 25\% раскрытых преступлений относятся к категории тяжких и особо тяжких (38,5 тыс.) ${ }^{3}$.

Тревогу вызывает сфера учета преступлений, формирования уголовноправовой статистики и раскрываемость преступлений. Правоохранительные органы, в особенности полиция, ненадлежаще реагируют на поступившие сигналы о преступлениях. Не изжита практика сокрытия их от учета. При этом в первом полугодии 2013 г. более 425 тыс. преступлений, в т.ч. свыше 106 тыс. тяжких, остались нераскрытыми.

Продолжается сокращение количества зарегистрированных преступлений, совершенных участниками организованных преступных формирований. Происходит расширение и укрепление экономической базы,

\footnotetext{
${ }^{1}$ Состояние законности и правопорядка в Российской Федерации и работа органов прокуратуры. 2012 год: информационно-аналитическая записка / под общ. ред. ректора Академии Генеральной прокуратуры Российской Федерации д-ра юрид. наук, проф. О.С. Капинус. М., 2013. 343 с.

Дамаскин О.В. Коррупция: состояние, причины, противодействие. М.: Триумфальная арка, 2009. С. 32.

Состояние преступности и основные результаты оперативно-служебной деятельности органов внутренних дел за январь-март 2013 г. / ОАД МВД России. С. 5.
} 
усиление негативного влияния организованных преступных формирований как на территории нашей страны, так и за пределами России ${ }^{1}$.

Масштаб задач, стоящих перед преступными организациями (сообществами), определяет выбор представителями криминалитета соответствующих методов борьбы за государственную и муниципальную власть.

Роль преступных организаций (сообществ) в политической системе общества выражается в их функциях, к числу которых относятся:

а) представительство социально-политических интересов определенной части общества;

б) фактическое осуществление отдельных государственно-властных полномочий («теневая» юстиция, воспитание и трудоустройство подростков из неблагополучных семей и др.);

в) разработка и реализация политической стратегии и тактики борьбы за государственную власть в ходе выборов.

Функция представительства социально-политических интересов проявляется в том, что кандидаты преступных организаций (сообществ) выражают интересы ряда социальных групп и располагают определенной поддержкой в обществе.

Как справедливо отмечает О.В Дамаскин, «неразвитость партийнополитической системы в России, отсутствие полноценных политических партий, реально выражающих интересы конкретных социальных групп, привели к тому, что партии стали развиваться по двум направлениям: либо представлять интересы вертикали исполнительной власти, либо превращаться в своего рода бизнес-проекты по зарабатыванию средств путем получения поддержки от власти в обмен на голоса при рассмотрении того или иного вопроса в законодательном органе»².

1 Постановление Всероссийского координационного совещания руководителей правоохранительных органов Российской Федерации от 21.02.2011 № 1 «О неотложных мерах по противодействию преступности, усилению охраны общественного порядка, активизации профилактики противоправного поведения».

2 Дамаскин О.В. Коррупция: состояние, причины, противодействие. М.: Триумфальная арка, 2009. С. 54-55. 
В связи с данными обстоятельствами коррупционная составляющая политического процесса стала выражаться в лоббировании одних законопроектов и торможении других в интересах конкретных финансовопромышленных групп, которые финансируют партии и экономически стимулируют деятельность депутатов, способных оказать влияние на решения законодательных органов. А поскольку криминальные сообщества обладают немалым ресурсом влияния в сфере экономики, отдельные политики и партийные функционеры, по существу, начинают выражать не только экономические, но и криминальные групповые интересы.

Традиционной практикой во многих регионах Российской Федерации стало назначение на должности за деньги или коррупционную ренту. Отсутствие реального механизма формирования кадрового потенциала власти, неэффективность форм подготовки и переподготовки кадров для государственной и муниципальной службы, полное отсутствие системы ротации управленческих кадров высшего звена - все это привело к системному кризису управления, его профессиональной деградации ${ }^{1}$.

Неудивительно, что в этих условиях часть населения выступила в поддержку состоятельных, активных, деловитых и организованных представителей уголовного мира. Так, по данным проведенного Фондом «Общественное мнение» Всероссийского опроса городского и сельского населения 44 субъектов Российской Федерации, 4 \% опрошенных граждан полагают, что навести порядок в государстве могут только представители организованных преступных групп, потому что «криминал привык к дисциплине», «порядка больше в их среде». $2 \%$ респондентов считают представителей уголовной среды честными, справедливыми, умными людьми с большим жизненным опытом, умеющими держать данное слово («они жизнь лучше понимают», «они зачастую более порядочные, чем политики») $)^{2}$.

В общественном сознании населения некоторых субъектов Российской Федерации сформировались толерантность и симпатии среди населения в

1 Дамаскин О.В. Указ. соч. С. 25.

2 Петрова A. Криминал во власти - обычное явление? //bd.fom.ru/report/map/projects. См. также. Полунин А. «Братки» собрались во власть // Труд. 2004. 10 августа. № 148. 
отношении избранных в органы государственной власти и местного самоуправления представителей преступных организаций и связанных с уголовной средой кандидатов на выборные должности. В ряде субъектов Российской Федерации представители криминалитета пользуются уважением среди населения. Необходимо отметить, что представители организованных преступных групп активно поддерживают усиление криминального влияния в обществе, в том числе в молодежной среде. Известны случаи организации спортивных секций, клубов по интересам, развлекательных центров и дискотек, находящихся под влиянием представителей организованной преступности и финансирующихся из их источников.

Фактическое осуществление преступными организациями (сообществами) отдельных государственно-властных полномочий, обращение населения за помощью к криминалитету обусловлено наличием у криминальных структур выстроенной системы управления, в которой сочетаются постановка четких и реальных задач, минимизация бюрократической волокиты, распределение ролей, строгая подчиненность, контроль и взаимная ответственность исполнителей, а также аппарата принуждения.

Как уже отмечалось выше, преступные организации (сообщества) принимают активное участие в борьбе за государственную власть ${ }^{1}$ Экономическая состоятельность преступных организаций (сообществ) и подконтрольных им финансово-промышленных структур позволяет представителям криминалитета выступать основными спонсорами избирательных кампаний, контролировать деятельность судей, избирательных комиссий, правоохранительных органов и СМИ.

В период подготовки и проведения выборов кандидаты, представляющие интересы преступных сообществ, выступают как активные сторонники реализации партийных программ, демонстрируют готовность и умение решать социально-значимые вопросы: асфальтируют дороги,

1 Подробней см. Красинский В.В. Проблемы борьбы с криминалитетом в ходе избирательных кампаний // Юридический мир. 2003. № 9. С. 4-8; Красинский В.В. Участие организованных преступных групп в избирательных кампаниях // Политика и общество. 2008. № 4. C. 7-13. 
устанавливают памятные доски воинам-участникам Великой Отечественной Войны, строят детские площадки, стремятся участвовать в осуществлении культурно-воспитательных и патриотических мероприятий.

Несмотря на это, пронизанный криминальными элементами и находящимися у них на содержании коррумпированными чиновниками и сотрудниками правоохранительных органов, сформированный за счет преступных доходов, выражающий личные и узкокорпоративные интересы государственный механизм власти в глазах населения постепенно утрачивает свою социально-политическую ценность. Государственная власть, осуществляемая антигосударственными элементами и противопоставляющая себя государству, не может эффективно и долговременно управлять общественными делами. Такой аппарат управления стратегически всегда будет нацелен на воспроизводство и охрану своих криминальных звеньев.

Монополизация представителями криминалитета имущественных комплексов, финансовых потоков и правотворческих процедур муниципальных образований отдельных субъектов Российской Федерации позволяет им сохранять и трансформировать выгодные общественноэкономические и политические отношения с учетом динамики меняющейся обстановки. Наличие легальных прикрытий в федеральных и региональных органах власти, спецслужбах, правоохранительных, контрольно-надзорных и финансовых органах существенно затрудняет декриминализацию данного управленческого механизма.

Проведенный анализ места и роли преступных организаций (сообществ) в политической системе российского общества свидетельствует об институционализации и частичной легализации криминальных структур в политической системе и исключительной общественной опасности подобного явления. 


\section{2. ПАРТИЙНЫЕ СПИСКИ НА ВЫБОРАХ В ГОСУДАРСТВЕННУЮ ДУМУ ФЕДЕРАЛЬНОГО СОБРАНИЯ РОССИЙСКОЙ ФЕДЕРАЦИИ ШЕСТОГО СОЗЫВА: КАНДИДАТЫ С УГОЛОВНЫМ ПРОШЛЫМ И АНТИКРИМИНАЛЬНАЯ ПОЛИТИКА ГОСУДАРСТВА}

Одним из важнейших и крупномасштабных общественнополитических мероприятий в нашей стране являются выборы депутатов Государственной Думы Федерального Собрания Российской Федерации. В ходе данной избирательной кампании каждый из нас осуществляет выбор между политическими лидерами, их программами и выдвинутыми партиями кандидатами, претендующими на осуществление государственной власти и народного представительства. Принимая политические решения, мы основываем свои предпочтения на личных симпатиях и имеющихся на избирательных участках сведениях о партийных лидерах и наиболее известных региональных функционерах.

Помимо биографических данных кандидатов, сведений об их доходах и имуществе, неснятых и непогашенных судимостях, в контрольноревизионные службы при избирательных комиссиях поступает информация о привлечении выдвинутых кандидатов к уголовной ответственности, об избрании в отношении некоторых из них меры пресечения в виде заключения под стражу, основаниях прекращения уголовного преследования данных лиц, выявленных фактах сокрытия кандидатами сведений о неснятых (непогашенных) судимостях ${ }^{1}$.

К сожалению, избиратели имеют весьма поверхностное представление о криминологических характеристиках формируемого депутатского корпуса и юридической «чистоте» своих будущих представителей в Государственной Думе Федерального Собрания Российской Федерации.

1 Лицо, осужденное за совершение преступления, считается судимым со дня вступления обвинительного приговора суда в законную силу до момента погашения или снятия судимости. Имеющаяся у лица непогашенная или неснятая судимость порождает особые, складывающиеся на основе уголовно-правового регулирования, публичноправовые отношения его с государством. 
В соответствии с пунктом 2.1 статьи 33 Федерального закона от 12 июня 2002 г. № 67-Ф3 «Об основных гарантиях избирательных прав и права на участие в референдуме граждан Российской Федерации» кандидаты в депутаты и кандидаты на выборные должности обязаны указывать в заявлении о согласии баллотироваться о наличии у кандидата неснятой и непогашенной судимости. Указанная обязанность появилась в Федеральном законе «Об основных гарантиях избирательных прав и права на участие в референдуме граждан Российской Федерации» с 25 июля 2005 г.

В соответствии с пунктом 3.2 статьи 4 Федерального закона «Об основных гарантиях избирательных прав и права на участие в референдуме граждан Российской Федерации» в ред. от 5 декабря 2006 г., действовавшей до 1 июня 2012 г., было запрещено избираться гражданам, осужденным к лишению свободы за совершение тяжких и (или) особо тяжких преступлений и имеющих на день голосования на выборах неснятую и непогашенную судимость за указанные преступления.

В Государственной автоматизированной системе «Выборы», начиная с июля 2005 г., фиксировалось только наличие неснятой и непогашенной судимости. Указание иных сведений, например, наличия у кандидата в прошлом погашенной судимости, участия кандидата в качестве одной из сторон в уголовном процессе и т.п., не требовалось, а потому в базах данных ГАС «Выборы» не фиксировалось ${ }^{1}$. Для проверки достоверности сведений о наличии (отсутствии) неснятой и (или) непогашенной судимости избирательные комиссии направляли соответствующие представления в органы внутренних дел, которые предоставляли соответствующую информацию.

В рамках данного исследования автором проведен анализ соответствующих сведений о кандидатах, выдвинутых политическими

\footnotetext{
${ }^{1}$ Информационно-аналитические материалы Аппарата ЦИК России «Об участии в избирательных кампаниях 2008-2012 гг. в качестве кандидатов на выборные должности лиц с неснятой и (или) непогашенной судимостью». С.1.
} 
партиями, принимавшими участие в выборах депутатов Государственной Думы Федерального Собрания Российской Федерации шестого созыва, а также подготовлены предложения по совершенствованию отдельных законодательных актов по линии противодействия криминализации органов публичной власти ${ }^{1}$.

В выборах депутатов Государственной Думы Федерального Собрания Российской Федерации шестого созыва участвовали 7 политических партий: политическая партия СПРАВЕДЛИВАЯ РОССИЯ, Либеральнодемократическая партия России, ПАТРИОТЫ РОССИИ, Коммунистическая партия Российской Федерации, Российская объединенная демократическая партия «ЯБЛОКО», Всероссийская политическая партия «ЕДИНАЯ РОССИЯ» и Всероссийская политическая партия «ПРАВОЕ ДЕЛО»².

В федеральном списке кандидатов политической партии СПРАВЕДЛИВАЯ РОССИЯ было 576 кандидатов, общефедеральная часть списка включала 8 кандидатов и 73 региональные группы.

Список Либерально-демократической партии России состоял из 307 кандидатов, в том числе 10 кандидатов в общефедеральной части списка и 292 кандидата в составе 82 региональных групп.

В зарегистрированном ЦИК России федеральном списке кандидатов политической партии «ПАТРИОТЫ РОССИИ» было 298 фамилий, в том

1 Проблемы криминализации российской политической системы и механизмы противодействия попыткам продвижения преступными организациями (сообществами) своих кандидатов в органы власти исследовали В.Д. Зорькин, В.В. Красинский, А. Петрова, Н.В. Щедрин. См. Зорькин В.Д. Конституция против криминала // Рос. газ. 2010. 10 декабря; Красинский В.В. Проблемы борьбы с криминалитетом в ходе избирательных кампаний // Юр. Мир. 2003. № 9. С. 4-8; Красинский В.В. Участие организованных преступных групп в избирательных кампаниях // Политика и общество. 2008. № 4. С. 7-13; Красинский B.B. Преступные организации (сообщества) как элемент политической системы российского общества // Человеческий капитал. 2011. № 1. С. 95-99; Петрова A. Криминал во власти - обычное явление? // Труд. 2004. 10 августа; Щедрин Н.В. Криминальное прошлое как основание ограничения пассивного избирательного права // Сб. материалов международной научно-практической конференции памяти д.ю.н. профессора В.И. Горобцова.Ч.1. Красноярск, 2005. С. 300 - 303.

${ }^{2}$ Федеральные списки кандидатов в депутаты Государственной Думы Федерального Собрания Российской Федерации шестого созыва, выдвинутые политическими партиями и зарегистрированные Центральной избирательной комиссией Российской Федерации. Специальный информационный выпуск ЦИК РФ // Рос. газ. 2011. 4 декабря. 200 с. 
числе 10 - в общефедеральной части списка и 288 - в составе 83 региональных групп.

Список Коммунистической партии Российской Федерации включал 590 кандидатов, в том числе 10 кандидатов в общефедеральной части списка и 580 - в 73 региональных группах.

Федеральный список Российской объединенной демократической партии «Яблоко» состоял из 10 кандидатов в общефедеральной части списка и 350 кандидатов в 78 региональных группах.

Как и на предыдущих выборах, Всероссийская политическая партия «Единая Россия» зарегистрировала самый многочисленный федеральный список из 597 фамилий. В общефедеральную часть списка был включен 1 кандидат - Президент Российской Федерации Медведев Д.А. 596 кандидатов были включены в состав 80 региональных групп. Региональные группы «Единой России возглавлялись высшими должностными лицами субъектов Российской Федерации (главами республик, губернаторами, главами администраций), депутатами Государственной Думы Федерального Собрания Российской Федерации, депутатами законодательных органов государственной власти субъектов Российской Федерации, руководящими должностными лицами Правительства Российской Федерации или федеральными министрами ${ }^{1}$.

В федеральном списке кандидатов Всероссийской политической партии «ПРАВОЕ ДЕЛО» было 576 кандидатов, общефедеральная часть списка включала 10 кандидатов и 77 региональных групп.

Самым «грязным» в криминальном отношении был федеральный список кандидатов политической партии СПРАВЕДЛИВАЯ РОССИЯ. В указанном федеральном списке в численном отношении по сравнению со

${ }^{1}$ Во главе региональных групп зарегистрированного списка Единой России было 52 высших должностных лица субъектов Российской Федерации, 12 депутатов Государственной Думы Федерального Собрания Российской Федерации, 3 депутата законодательных органов государственной власти субъектов Российской Федерации, 6 руководящих должностных лиц Правительства Российской Федерации, 2 федеральных министра. 
списками других политических партий, участвовавших в федеральных выборах 2011 года, содержалось наибольшее количество кандидатов в депутаты, подвергавшихся уголовному преследованию и имеющих погашенные судимости ${ }^{1}$.

Из выдвинутого политической партией СПРАВЕДЛИВАЯ РОССИЯ федерального списка кандидатов в депутаты Государственной Думы Федерального Собрания Российской Федерации шестого созыва до регистрации было исключено трое кандидатов с криминальным прошлым.

В зарегистрированном списке партии СПРАВЕДЛИВАЯ РОССИЯ осталось 46 кандидатов, привлекавшихся к уголовной ответственности, в том числе 10 с погашенными и 1 с непогашенной судимостью2.

3 кандидата были осуждены за совершение преступлений против свободы, чести и достоинства личности («клевета»), 3 кандидата - за совершение преступлений против общественной безопасности (двое за хулиганство, один за незаконное ношение, хранение, приобретение, изготовление или сбыт оружия, боевых припасов или взрывчатых веществ), 3 - за преступления в сфере экономической деятельности («незаконное предпринимательство»), 2 - за преступления против порядка управления («оскорбление представителя власти» и «подделка, изготовление или сбыт поддельных документов, государственных наград, штампов, печатей, бланков»), 1 - за совершение преступления против конституционных прав и свобод человека и гражданина («нарушение изобретательских и патентных прав»).

${ }^{1}$ Необходимо сделать оговорку, что ряд представителей уголовной среды не имеет (никогда не имел) судимостей. Кроме того, для проникновения в федеральный и региональные органы законодательной власти криминальными элементами используется сознательное искажение установочных данных (отчество, дата рождения), удаление сведений о себе из региональных баз правоохранительных органов, а также продвижение «незасвеченных» ставленников (нередко близких родственников), не имеющих судимостей и выявленных связей с организованной преступностью. Это затрудняет проверки указанных граждан по учетам ФГБУ «ГИАЦ МВД России» и информационных центров территориальных органов МВД России и дает им возможность избираться в органы государственной власти.

${ }^{2}$ Неснятую судимость по ч.2 ст. 129 УК РФ указал один кандидат (региональная группа № 30). 
Из числа лиц, имеющих погашенные судимости, четверо - депутаты законодательных органов государственной власти субъектов Российской Федерации и представительных органов муниципальных образований, один является главой муниципального образования, трое - председатели советов местных отделений партии, один - председатель первичного отделения партии. 4 осужденных были освобождены от наказания постановлением Государственной Думы Федерального Собрания Российской Федерации об объявлении амнистии.

В отношении 6 кандидатов, подвергавшихся уголовному преследованию (среди них 4 депутата), уголовные дела были прекращены по п.3 ст. 24 УПК РФ в связи с истечением сроков давности уголовного преследования, причем один из кандидатов (депутат законодательного органа государственной власти субъекта Российской Федерации на непостоянной основе) в 2008 г. привлекался к уголовной ответственности по ч.1 ст.141 УК РФ («Воспрепятствование осуществлению избирательных прав или работе избирательных комиссий»).

В отношении 5 кандидатов (один из них депутат) уголовные дела были прекращены по ст. 25 УПК РФ в связи с примирением сторон или по ст. 9 УПК РСФСР в связи с примирением с потерпевшим. В отношении 5 кандидатов (из них двое - депутаты) уголовные дела были прекращены вследствие акта об амнистии (пп.3 п.1 ст. 27 УПК РФ и п.4 ст.5 УПК РСФСР), в отношении 5 (трое - депутаты) - в связи с деятельным раскаянием (ст. 28 УПК РФ). Один из кандидатов (депутат Государственной Думы Федерального Собрания Российской Федерации) находится в федеральном розыске (мера пресечения - арест), в отношении другого кандидата (депутат муниципального собрания на непостоянной основе) розыск был прекращен в январе 2010 года. По двум кандидатам велось следствие.

Из выдвинутого политической партией «Коммунистическая партия Российской Федерации» федерального списка кандидатов в депутаты Государственной Думы Федерального Собрания Российской Федерации 
шестого созыва до регистрации было исключено два кандидата с криминальным прошлым.

В зарегистрированном списке партии «Коммунистическая партия Российской Федерации» осталось 37 кандидатов, привлекавшихся к уголовной ответственности, в том числе 11 с погашенными судимостями.

Один кандидат имел две судимости.

1 кандидат был осужден за совершение преступления против свободы, чести и достоинства личности («незаконное лишение свободы»), 4 кандидата - за совершение преступлений против собственности (один за кражу, один за грабеж и двое за мошенничество), 2 - за преступления в сфере экономической деятельности («уклонение от уплаты налогов и (или) сборов с организации», «незаконное предпринимательство»), 2 - за преступления против безопасности движения и эксплуатации транспорта, 1 - за совершение преступления против государственной власти, интересов государственной службы и службы в органах местного самоуправления («халатность»), 1 - за преступление против правосудия (незаконные действия в отношении имущества, подвергнутого описи или аресту либо подлежащего конфискации»).

Из числа лиц, имеющих погашенную судимость, четверо - депутаты законодательных органов государственной власти субъектов Российской Федерации и представительных органов муниципальных образований, один является первым секретарем городского отделения, один - первым секретарем районного отделения партии. 4 осужденных были освобождены от наказания постановлением Государственной Думы Федерального Собрания Российской Федерации об объявлении амнистии.

В отношении 3 кандидатов (среди них 1 депутат) уголовные дела были прекращены по п.3 ст. 24 УПК РФ в связи с истечением сроков давности уголовного преследования. В отношении 6 кандидатов (4 из них депутаты) уголовные дела были прекращены по ст. 25 УПК РФ в связи с примирением сторон или по ст. 9 УПК РСФСР в связи с примирением с потерпевшим. В 
отношении 2 кандидатов (один из них - секретарь комитета регионального отделения, другой - член бюро областного комитета) уголовные дела были прекращены вследствие акта об амнистии (пп.3 п.1 ст. 27 УПК РФ и п.4 ст.5 УПК РСФСР), в отношении 2 (один - первый секретарь комитета республиканского отделения) - в связи с деятельным раскаянием (ст. 28 УПК РФ).

В отношении двух кандидатов проводилось предварительное следствие, в отношении одного из них была избрана мера пресечения в виде заключения под стражу (ст. 98 УПК РФ).

Из выдвинутого политической партией «ЯБЛОКО» федерального списка кандидатов в депутаты Государственной Думы Федерального Собрания Российской Федерации шестого созыва до регистрации было исключено семь кандидатов с криминальным прошлым.

В зарегистрированном списке партии «ЯБЛОКО» осталось 16 кандидатов, привлекавшихся к уголовной ответственности, в том числе 10 с погашенными судимостями и 1 с непогашенной судимостью1.

3 кандидата были осуждены за совершение преступлений против свободы, чести и достоинства личности («клевета», «оскорбление»), 2 кандидата - за совершение преступлений против собственности («причинение имущественного ущерба путем обмана или злоупотребления доверием» и «хищение общественного имущества, совершенное путем мошенничества»), 2 - за преступления в сфере экономической деятельности («обман потребителя», «незаконное предпринимательство»), 2 - за преступления против безопасности движения и эксплуатации транспорта, 2 за совершение преступлений против государственной власти, интересов государственной службы и службы в органах местного самоуправления («дача взятки», «получение взятки»), 1 - за преступление против общественной безопасности, общественного порядка и здоровья населения

${ }^{1}$ Непогашенную судимость по ч.3 ст. 129 УК РФ («клевета») указал один кандидат (региональная группа № 66). Судимость не погашена в связи с отказом осужденного выполнить решение суда. 
(«приобретение или сбыт имущества, заведомо добытого преступным путем»), 1 - за преступление против жизни и здоровья («побои») и 1 - за преступление против основ конституционного строя и безопасности государства («призывы к насильственному изменению конституционного строя») $)^{1}$.

Из числа лиц, имеющих судимость, один являлся депутатом представительного органа муниципального образования на непостоянной основе, два - председателями региональных отделений партии, один председателем местного отделения партии.

1 осужденный был освобожден от наказания постановлением Государственной Думы Федерального Собрания Российской Федерации об объявлении амнистии.

В отношении 1 кандидата, подвергавшегося уголовному преследованию (член Федерального Совета партии), уголовное дело было прекращено в связи с истечением сроков давности уголовного преследования. В отношении 1 кандидата (член Регионального Совета партии) уголовное дело было прекращено в связи с примирением сторон. В отношении 2 кандидатов уголовные дела были прекращены вследствие акта об амнистии (пп.3 п.1 ст. 27 УПК РФ и п.4 ст.5 УПК РСФСР), в отношении 2 (один - председатель регионального отделения партии) - в связи с деятельным раскаянием (ст. 28 УПК РФ).

Два кандидата находились под следствием, в отношении одного из них (депутат представительного органа муниципального образования на непостоянной основе) была избрана мера пресечения в виде заключения под стражу (ст. 98 УПК РФ).

Самыми «чистыми» в криминальном плане стали федеральные списки кандидатов, зарегистрированные политической партией «Либерально-

1 Некоторые кандидаты были осуждены по совокупности составов преступлений. 
демократическая партия России» и Всероссийской политической партией «ЕДИНАЯ РОССИЯ» 1.

Из выдвинутого политической партией «Либерально-демократическая партия России» федерального списка кандидатов в депутаты Государственной Думы Федерального Собрания Российской Федерации шестого созыва до регистрации было исключено два кандидата с криминальным прошлым.

В зарегистрированном списке партии «Либерально-демократическая партия России» осталось 9 кандидатов, привлекавшихся к уголовной ответственности (двое из них - депутаты Государственной Думы Федерального Собрания Российской Федерации), в том числе 3 с погашенными судимостями.

1 кандидат был осужден за совершение преступления против общественной безопасности («хулиганство»), 1 кандидат - за преступление против жизни, здоровья, свободы и достоинства личности («изнасилование»), 1 кандидат - за преступление против правосудия («побег из места лишения свободы, из-под ареста или из-под стражи»).

Из числа лиц, имеющих погашенную судимость, один кандидат являлся депутатом Государственной Думы Федерального Собрания Российской Федерации, членом комитета Государственной Думы по безопасности.

В отношении 2 кандидатов, подвергавшихся уголовному преследованию (депутат законодательного органа государственной власти субъекта Российской Федерации и депутат представительного органа муниципального образования), уголовные дела были прекращены по ст. 25 УПК РФ в связи с примирением сторон или по ст. 9 УПК РСФСР в связи с примирением с потерпевшим. В отношении 1 кандидата (депутат законодательного органа государственной власти субъекта Российской

1 Зарегистрированные федеральные списки указанных партий содержали наименьшее число лиц, привлекавшихся к уголовной ответственности и имеющих погашенные судимости. 
Федерации) уголовное дело было прекращено в связи с деятельным раскаянием (ст. 28 УПК РФ).

Из выдвинутого Всероссийской политической партией «ЕДИНАЯ РОССИЯ» федерального списка кандидатов в депутаты Государственной Думы Федерального Собрания Российской Федерации шестого созыва до регистрации был исключен один кандидат с криминальным прошлым.

В зарегистрированном федеральном списке кандидатов в депутаты Государственной Думы Федерального Собрания Российской Федерации шестого созыва партии «ЕДИНАЯ РОССИЯ» осталось 10 кандидатов, привлекавшихся к уголовной ответственности, в том числе 2 ранее судимых.

1 кандидат был осужден за совершение преступления против общественной безопасности («незаконное ношение, хранение, приобретение, изготовление или сбыт оружия, боевых припасов или взрывчатых веществ»), 1 - за совершение преступления против конституционных прав и свобод человека и гражданина («нарушение правил охраны труда»).

В отношении 1 кандидата уголовное дело было прекращено в связи с истечением сроков давности уголовного преследования, в отношении 1 кандидата (депутат законодательного органа государственной власти субъекта Российской Федерации на непостоянной основе) - в связи с примирением сторон.

Из выдвинутого политической партией «ПАТРИОТЫ РОССИИ» федерального списка кандидатов в депутаты Государственной Думы Федерального Собрания Российской Федерации шестого созыва до регистрации было исключено девять кандидатов с криминальным прошлым.

В зарегистрированном списке партии «ПАТРИОТЫ РОССИИ» осталось 14 кандидатов, привлекавшихся к уголовной ответственности, в том числе 4 с погашенными судимостями.

1 кандидат был осужден за совершение преступления против жизни, здоровья, свободы и достоинства личности («умышленное тяжкое телесное повреждение»), 1 кандидат - за совершение преступления против 
собственности («умышленное уничтожение или повреждение имущества»), 1 - за преступление против безопасности движения и эксплуатации транспорта («нарушение правил безопасности движения и эксплуатации транспорта»), 1 - за совершение преступления против государственной власти, интересов государственной службы и службы в органах местного самоуправления («превышение должностных полномочий»).

Один кандидат имел неоднократные судимости.

В отношении 4 кандидатов, подвергавшихся уголовному преследованию, уголовные дела были прекращены по ст. 25 УПК РФ в связи с примирением сторон или по ст. 9 УПК РСФСР в связи с примирением с потерпевшим.

В отношении одного кандидата (депутат представительного органа муниципального образования) уголовное дело находилось на стадии судебного разбирательства.

Из выдвинутого Всероссийской политической партией «ПРАВОЕ ДЕЛО» федерального списка кандидатов в депутаты Государственной Думы Федерального Собрания Российской Федерации шестого созыва до регистрации было исключено десять кандидатов с криминальным прошлым.

В зарегистрированном федеральном списке кандидатов в депутаты Государственной Думы Федерального Собрания Российской Федерации шестого созыва партии «ПРАВОЕ ДЕЛО» осталось 23 кандидата, привлекавшихся к уголовной ответственности, в том числе 6 имеющих погашенную судимость.

2 кандидата были осуждены за совершение преступлений против свободы, чести и достоинства личности («клевета»), 2 кандидата - за совершение преступлений против собственности («мошенничество» и «присвоение или растрата»), 1 - за преступление против здоровья населения и общественной нравственности («незаконные приобретение, хранение, перевозка, изготовление, переработка наркотических средств, психотропных веществ или их аналогов, а также незаконные приобретение, хранение, 
перевозка растений, содержащих наркотические средства или психотропные вещества, либо их частей, содержащих наркотические вещества или психотропные вещества»), 1 - за совершение преступления против государственной власти, интересов государственной службы и службы в органах местного самоуправления («превышение должностных полномочий»).

Из числа лиц, имеющих погашенную судимость, один кандидат являлся депутатом представительного органа муниципального образования на непостоянной основе, два - членами политического совета региональных отделений партии.

В отношении 1 кандидата (член политического совета регионального отделения партии), уголовное дело было прекращено в связи с истечением сроков давности уголовного преследования. В отношении 3 кандидатов (двое из них - председатели местных отделений партии) уголовные дела были прекращены в связи с примирением сторон. В отношении 3 кандидатов (один из них - член политического совета регионального отделения партии) уголовные дела были прекращены вследствие акта об амнистии (пп.3 п.1 ст. 27 УПК РФ и п.4 ст.5 УПК РСФСР), в отношении 1 (председатель регионального отделения партии) - в связи с деятельным раскаянием (ст. 28 УПК РФ).

В отношении 1 кандидата в депутаты Государственной Думы проводилось предварительное следствие, в отношении 1 кандидата уголовное дело было направлено в суд, в отношении 1 кандидата велось дополнительное расследование по уголовному делу.

По результатам проведенных выборов депутатские мандаты были распределены между 4 политическими партиями. Всероссийская политическая партия «ЕДИНАЯ РОССИЯ» получила 238 депутатских мест в парламенте, Политическая партия «Коммунистическая партия Российской 
Федерации» - 92, Политическая партия СПРАВЕДЛИВАЯ РОССИЯ - 64, Политическая партия «Либерально-демократическая партия России» $-56^{1}$.

В списке избранных депутатов Государственной Думы Федерального Собрания Российской Федерации шестого созыва 9 депутатов привлекались к уголовной ответственности, 2 - имеют погашенные судимости ${ }^{2}$.

Анализ результатов выборов депутатов Государственной Думы Федерального Собрания Российской Федерации шестого созыва ставит перед нами насущные вопросы. Могут ли лица, привлекавшиеся к уголовной ответственности, работать в комитете Государственной Думы Федерального Собрания Российской Федерации по гражданскому, уголовному, арбитражному и процессуальному законодательству? Могут ли лица, привлекавшиеся к уголовной ответственности за совершение преступлений против собственности, работать в комитете Государственной Думы по экономической политике и предпринимательству? Могут являться депутатами Государственной Думы, членами комитета Государственной Думы по безопасности граждане-фигуранты уголовных дел, в чьих квартирах правоохранительные органы в ходе оперативно-розыскной деятельности обнаруживали автоматы без номеров с глушителями, магазины, сотни патронов и гранаты РГД-5?

На взгляд автора, существующая ситуация, при которой возможно избрание в органы государственной власти и органы местного самоуправления лиц, находящихся в федеральном розыске, содержащихся под стражей, привлеченных в качестве обвиняемых по уголовным делам, неоднократно судимых, в том числе по тяжким составам преступлений, недопустима.

1 Постановление ЦИК России от 9 декабря 2011 года № 70/576-6 «О результатах выборов депутатов Государственной Думы Федерального Собрания Российской Федерации шестого созыва» // Рос. газ. 2011. 10 декабря.

${ }^{2}$ В списке избранных депутатов Государственной Думы Федерального Собрания Российской Федерации пятого созыва 8 депутатов привлекались к уголовной ответственности, 2 - имели погашенные судимости. 


\section{3. МУНИЦИПАЛЬНЫЕ И РЕГИОНАЛЬНЫЕ ВЫБОРЫ В КОНТЕКСТЕ УСТРЕМЛЕНИЙ ПРЕСТУПНЫХ ОРГАНИЗАЦИЙ (СООБЩЕСТВ)}

Широкое информационное освещение федеральных избирательных кампаний, существенные материальные затраты политических партий и кандидатов, более строгий контроль за соблюдением законности и прозрачности избирательного процесса со стороны федеральных контролирующих и надзорных органов приводят к тому, что в современных условиях наиболее массовым каналом криминализации российской политической системы выступает участие представителей преступных организаций (сообществ) в муниципальных и региональных выборах.

25 февраля 2009 г., выступая на расширенном заседании Коллегии Генеральной прокуратуры Российской Федерации, Президент Российской Федерации Д.А. Медведев отметил, что на муниципальном уровне наблюдается довольно высокое представительство криминалитета. «Криминальные элементы, авторитеты и авторитетики местного масштаба не должны находиться в местных органах власти, а их там достаточное количество», - заявил глава государства ${ }^{1}$.

Криминализация российской политической системы осуществляется в двух основных направлениях: путем участия представителей организованной преступности в выборах с последующим избранием в органы власти и путем назначения представителей криминалитета на ключевые должности коррумпированными чиновниками государственного и муниципального аппаратов.

Данные Аппарата ЦИК России показывают на постоянство участия в избирательных кампаниях доли лиц с неснятой и (или) непогашенной судимостью. Суммарные значения по выборам всех уровней ((выборы депутатов Государственной Думы Федерального Собрания Российской 
Федерации и выборы Президента Российской Федерации; выборы в законодательные (представительные) органы государственной власти субъекта Российской Федерации и выборы высших должностных лиц субъекта Российской Федерации в октябре 2012 г.; выборы депутатов законодательных (представительных) органов муниципальной власти административных центров (столиц) субъектов Российской Федерации и выборы глав административных центров (столиц) субъектов Российской Федерации; выборы представительных органов местного самоуправления муниципальных образований (городские округа и муниципальные районы) и глав таких муниципальных образований)) в период с июля 2008 г. по октябрь 2012 г. составляли: июль - декабрь 2008 г. - 7 человек; январь - июнь 2009 г. - 17 человек; июль - декабрь 2009 г. - 9 человек; январь - июнь 2010 г. - 15 человек; июль - декабрь 2010 г. - 19 человек; январь - июнь 2011 г. - 26 человек; июль - декабрь 2011 г. - 17 человек; январь - июнь 2012 г. - 19 человек; июль - октябрь 2012 г. - 10 человек.

Преступления, совершенные рассматриваемой категорией лиц, распределены в соответствии с Уголовным кодексом Российской Федерации по типам следующим образом: 35 судимостей за преступления против собственности; 23 судимости за преступления против государственной власти, интересов государственной службы и службы в органах местного самоуправления; 20 судимостей за преступления против жизни и здоровья; 17 судимостей за преступления в сфере экономической деятельности; 12 судимостей за преступления против порядка управления; 11 судимостей за преступления против правосудия; 9 судимостей за преступления против свободы, чести и достоинства личности; по 5 судимостей за преступления против общественной безопасности, преступления против основ конституционного строя и безопасности государства, экологические преступления; по 4 судимости за преступления против здоровья населения и общественной нравственности, преступления против безопасности движения и эксплуатации транспорта; по 3 судимости за преступления против конституционных прав и свобод человека и гражданина, преступления против 
интересов службы в коммерческих и иных организациях; 1 судимость за преступления против военной службы ${ }^{1}$.

Официальная статистика избирательных комиссий расходится с данными правоохранительных органов и спецслужб. Это объясняется тем, что избирательные комиссии анализируют участие лиц с криминальным прошлым в избирательных кампаниях только по параметру наличия судимости за совершение тяжких и (или) особо тяжких преступлений, в то время как по информационно-справочным учетам правоохранительных органов и спецслужб регистрируются данные о криминальных связях, участии граждан в деятельности преступных организаций (сообществ), о процессуальных и следственных действиях, проведенных в отношении граждан органами дознания и следствия, а также иная оперативно-значимая информация.

Практика региональных и муниципальных выборов, прошедших в 20062013 гг., свидетельствует о новых тенденциях участия организованных преступных групп в избирательных кампаниях ${ }^{2}$.

Bo-nepвblx, в настоящее время заметно снизилось число представителей организованных преступных групп, непосредственно баллотирующихся в депутаты или на выборные должности. Сейчас лидеры уголовной среды предлагают перспективным кандидатам свое участие в финансировании

${ }^{1}$ Информационно-аналитические материалы Аппарата ЦИК России «Об участии в избирательных кампаниях 2008-2012 гг. в качестве кандидатов на выборные должности лиц с неснятой и (или) непогашенной судимостью». С.5.

${ }^{2}$ См.: Красинский В.В. Участие организованных преступных групп в избирательных кампаниях // Политика и общество. 2008. № 4. С. 7-13. См. также Доклад Председателя ЦИК России В.Е. Чурова «Об изменениях избирательного законодательства в связи с реализацией положений Послания Президента Российской Федерации Федеральному Собранию Российской Федерации в 2008 году, задачах избирательных комиссий в связи с указанными изменениями и предложениях избирательных комиссий по совершенствованию законодательства Российской Федерации о выборах и референдумах» / Материалы совещания с председателями избирательных комиссий субъектов Российской Федерации, входящих в Центральный федеральный округ (г. Красногорск, 21 мая 2009 г.); Доклад Заместителя Председателя ЦИК России Л.Г. Ивлева «Об опыте работы избирательных комиссий и задачах избирательных комиссий Приволжского федерального округа по подготовке и проведению выборов» / Материалы совещания с председателями избирательных комиссий субъектов Российской Федерации, входящих в Приволжский федеральный округ (г. Казань, 5 июня 2009 г.); Выступление помощника полномочного представителя Президента Российской Федерации в Северо-Западном федеральном округе Е.И. Макарова / Материалы совещания с председателями избирательных комиссий субъектов Российской Федерации, входящих в Северо-Западный федеральный округ (г. Гатчина, 3 сентября 2009 г.). 
избирательной кампании либо самостоятельно заблаговременно готовят для внедрения в органы государственной власти и местного самоуправления своих «незасвеченных» ставленников (нередко близких родственников), не имеющих судимостей, не скомпрометировавших себя выявленными связями с организованными преступными группами.

Bo-вторых, несмотря на легализацию статуса и доходов, никто из депутатов или выборных должностных лиц, являющихся лидерами уголовной среды, не распустил свои боевые группировки («боевиков»). Как правило, эти структуры действуют под прикрытием частных охранных предприятий или служб безопасности. Таким образом, в ходе организации и проведения выборов у представителей организованных преступных групп сохраняется возможность использовать силовое воздействие на избирательный процесс для оказания влияния на принятие политических решений, дестабилизации обстановки и устрашения населения. Кроме того, лидеры этнических преступных групп, действующих на территории Российской Федерации, могут использовать свои боевые подразделения в ходе межнациональных столкновений, периодически возникающих в отдельных субъектах Российской Федерации.

$B$-третьих, с учетом повышения роли политических партий в избирательном процессе важнейшей задачей уголовной разведки и контрразведки стало установление контроля организованных преступных групп над ведущими политическими партиями (региональными отделениями политических партий) и продвижение своих представителей в органы государственной власти, местного самоуправления и избирательные комиссии с использованием партийных структур ${ }^{1}$. Руководство ряда политических партий (региональных отделений) вместо декларируемой кадровой политики

1 Так, в ходе выборов 11 октября 2009 г. в органы местного самоуправления Республики Ингушетия региональными отделениями политических партий «Единая Россия» и «Справедливая Россия» был выдвинут 51 кандидат, связанный с криминальной средой, из них 27 человек были избраны депутатами городских, районных и сельских советов Республики Ингушетия. По итогам выборов 11 октября 2009 г. в органы местного самоуправления Мурманской области депутатами Совета депутатов Кандалакшского района стали 2 представителя «Единой России», имеющие устойчивые связи с лидерами организованной преступной группы «Сороковуха» и причастные к незаконному обороту наркотических средств. 
противодействия криминалитету (проверки кандидатов в члены партии, выявления фактов партийной коррупции и передачи собранных материалов правоохранительным органам, проверки членов партии, баллотирующихся по партийным спискам, исключения из партии лиц, скомпрометировавших себя связями с экстремистскими организациями и организованными преступными группами) использует существующую систему списков кандидатов для включения на возмездной основе лиц, связанных с криминальной средой, в т.н. «закрытую» часть партийных списков. Отмечаются факты, когда по предложениям партий кандидатуры представителей криминальной среды вносятся для избрания в качестве высшего должностного лица субъекта Российской Федерации.

B-четвертых, представителями организованных преступных групп практически перестало осуществляться отмывание денежных средств в ходе выборов. Данное обстоятельство обусловлено наличием у организованных преступных групп многообразных законных источников финансирования избирательных кампаний и ужесточением юридической ответственности за нарушение порядка финансирования выборов.

Указанные тенденции участия организованных преступных групп в избирательных кампаниях затрудняют целенаправленную деятельность правоохранительных органов по недопущению представителей криминалитета в органы государственной власти и местного самоуправления в ходе выборов и усиливают общественную опасность подобных процессов.

Свои особенности имеет вмешательство криминальных структур в избирательный процесс на территории Северо-Кавказского региона. Наряду с общеуголовными преступными организациями, которые стремятся продвигать своих представителей в органы власти, на Северном Кавказе проявляют активность экстремистские группировки («джамааты»), которые прикрываются кораническими аятами и хадисами Пророка для осуществления своей преступной деятельности (убийств, похищения людей, разбоя, вымогательств, бандитизма, незаконного изготовления оружия и др.) 
Члены данных криминальных структур пропагандируют замену светских («безбожных», «кафирских») органов публичной власти властью шариатских институтов, отвергают ценность институтов народного представительства и конституционно-правовых процедур их формирования.

Призывы северо-кавказских бандгрупп к бойкоту выборов и общественно-политических мероприятий могут осуществляться под видом борьбы с коррумпированной государственной властью и преступностью.

Так, 7 марта 1999 года в Республике Дагестан прошли выборы в Народное Собрание Республики. Джамаат «кадарской зоны» блокировал их проведение в населенных пунктах Карамахи, Чабанмахи, Кадар, Чанкурбе и Ванашимахи.

«Там, «наверху», сами заявляют о том, что среди депутатов немало бывших уголовников. А нам вся эта грязь не нужна. Мы - мусульмане - за свои действия отвечаем перед Аллахом в Судный день. Для них важнее деньги и власть. Они забыли Ислам. Или же, где им надо, козыряют именем Ислама. Повторяю, такого лицемерия нам не надо. А если бы мы за них проголосовали, нам бы отвечать перед Аллахом». Так объяснил отказ от голосования военный «амир» карамахинского Джамаата Джарулла.

В ответ на обращение руководства Республики к населению указанных сел карамахинский джамаат направил в Махачкалу документ, в котором, в частности, говорилось: «В связи с тем, что республика не способна своей конституцией, многочисленными законами навести элементарный порядок, в Дагестане следует установить законы Аллаха. Только установив шариатские законы, можно навести порядок, как, например, в селах Карамахи и Чабанмахи» ${ }^{1}$.

Идеология отрицания участия в политической жизни и необходимости замены конституционных органов публичной власти шариатскими распространяется с помощью многочисленных обращений т.н. «амиров»

${ }^{1}$ Мантаев А.А. «Ваххабизм» и политическая ситуация в Дагестане. Дис. ... канд. полит. наук. М., 2002. С. 208. 
вилаятов «Имарата Кавказ» и фетв о вынесении такфира (обвинения в неверии) всем мусульманам, которые принимают участие в выборах.

Так, «амир» Гулям Мухаммад Дагестанский на экстремистском сайте «Имарата Кавказ» www.daavat.me об участии мусульман в политической жизни пишет: «Как хорошо, что первые мусульмане не слышали про волшебные слова «демократия», «толерантность», «права человека», «гуманизм». Как хорошо, что они не были по-европейски воспитаны, и не знали о том, что мусульмане могут принимать участие в выборах! Как хорошо, что они не знали о том, что куфр и Ислам имеют немало точек соприкосновения, общих целей и задач, общих друзей и врагов, общих принципов, обозначенных лукавой формулировкой «общечеловеческие ценности» ${ }^{1}$ !

«Амир» Абу Халид, обращаясь к мусульманам, взывает: «СубханАллах, мусульмане, очнитесь! Не поможет вам то, что вы участвуете в выборах, митингах, конференциях и прочих гнилых государственных проектах! $!^{2} \gg$.

В день выборов Президента Российской Федерации 4 марта 2012 г. на экстремистских сайтах VDagestan.com и Ummanews.com была опубликована фетва т.н. «Кадия Имарата Кавказ» шейха Али Абу Мухаммада, в которой он предостерег мусульман от участия в демократических выборах, которые являются «явным атрибутом куфра и ширка, завуалированного красивыми словами и выражениями».

По мнению Али Абу Мухаммада, «в понятие тагута (ложного поклонения помимо Аллаха) входят все, кто сделал себя законодателем вместо Аллаха, будь он правитель или подчиненный, или депутат законодательной власти, или тот, кто баллотировал ее из числа избирателей. Избегайте тагута! Не ходите на эти выборы! И не принимайте в них участие!

\footnotetext{
Гулям Мухаммад Дагестанский. Гарем чекиста // URL: http://www.davaat.me/?p=3665\#more-3665 (дата обращения: 11.05.2013).

2 Абу Халид. «..Их смелость равна ширине небес и земли, потому что они не боятся свого Создателя» // URL: http://www.islamdin.biz/2013/01/blog-post-2927.html (дата обращения: 11.05.2013).
} 
Мы заявляем следующее, как представители ахлю-Сунна-валь-Джамаа, как представители Имарата Кавказ: если кто-нибудь из мусульман, считающих себя мусульманином, пойдёт и примет участие в этих выборах и проголосует за какого-то президента или за какую-то партию, независимо - это президентские выборы, партийные или парламентские, разницы нет. Если он без принуждения примет участие в этих выборах, этим самым действием он ставит себя вне религии Ислам! То есть он выходит из Ислама! Его кровь, честь и имущество становятся дозволенными для всех мусульман. Ему ничего не поможет, не помогут ни Путин, ни Зюганов, ни какие-то партии, ни их приспешники, ни их рабы, никто не поможет!» ${ }^{1}$

В качестве инструмента постепенной замены конституционных «кафирских» органов власти на «шариатские» выступают непрекращающиеся посягательства на жизнь и теракты в отношении депутатов, должностных лиц и сотрудников органов власти и управления, сотрудников правоохранительных структур ${ }^{2}$.

Криминализация политической системы российского общества и попытки влияния преступных организаций на формирование и деятельность органов власти вызывают серьезную озабоченность не только у руководителей государственных органов разного уровня, но и у представителей структур гражданского общества.

Так, 16 ноября 2010 г. на заседании Координационного совета по защите избирательных прав граждан, проходившего в Общественной палате Российской Федерации, Председатель ЦИК России Чуров В.Е. сообщил, что в ходе выборов разного уровня заметно возросло число судимых кандидатов, баллотирующихся на выборные должности. Особенно это характерно для

${ }^{1}$ Кадий Имарата Кавказ Абу Мухаммад: «Тот, кто услышал наш довод, но все равно пошел на выборы и проголосовал, вышел из Ислама и стал муртадом» // URL: http://www.ummanews.com/opinions/5848-2012-03-04-04-54-10.html (дата обращения: 11.05.2013).

2 Расулов Я. Почему убивают милиционеров в Дагестане // Черновик. 2004. 16 апреля; Курбанов P. Расползание джихада: первичные факторы и масштабы радикализации ислама на Северном Кавказе // Центральная Азия и Кавказ. 2004. № 6 (36). C. 51-58. 
муниципальных выборов. Так, на выборах в Единый день голосования 10 октября 2010 г. представители криминалитета выдвигались в Московской области, Мурманской области (Кандалакша, Апатиты) и ряде других регионов (Республика Дагестан, Ростовская, Новгородская, Самарская области). Чуров В.Е. отметил, что при организации данных выборов были выявлены три кандидата с неснятыми судимостями за совершение особо тяжких преступлений.

В выборах 13 марта 2011 г. также участвовало значительное количество лиц с криминальным прошлым. В одной только Владимирской области в депутаты и на выборные должности баллотировалось 170 кандидатов, имеющих судимость. После информирования региональных отделений политических партий таких кандидатов стало 120 . В связи с наличием неснятых (непогашенных) судимостей за тяжкие и особо тяжкие преступления из списков были исключены 4 кандидата.

В ходе выборов 13 марта 2011 г. кандидатом в Калининградскую областную Думу был выдвинут депутат Полесского городского поселения 3., известный УВД по Калининградской области как организатор и активный участник «Полесской организованной преступной группы».

В феврале 2011 г. в избирательную комиссию Тамбовской области с заявлением о проведении проверки законности самовыдвижения кандидатом в депутаты Тамбовской областной Думы криминального авторитета П. обратилась группа членов регионального отделения КПРФ. Однако в ГИАЦ МВД России сведения о том, что П. («Поп») является лидером организованной преступной группы и имеет криминальные связи, не подтвердили. Позднее из опасений за свою жизнь и здоровье руководство комитета Тамбовского областного отделения партии заявило о том, что члены Тамбовского областного отделения КПРФ не имеют отношения к данному обращению ${ }^{1}$.

1 Сведения о поступивших в избирательные комиссии обращениях (жалобах и заявлениях) о заявленных нарушениях избирательного законодательства в ходе 
Многочисленные факты выдвижения и регистрации кандидатов с уголовным прошлым были зафиксированы в ходе выборов в органы государственной власти субъектов Российской Федерации и органы местного самоуправления административных центров субъектов Российской Федерации 8 сентября 2013 г.

Наибольшее количество зарегистрированных кандидатов, представляющих интересы криминальных структур, было отмечено на выборах депутатов Государственного Собрания - Курултая Республики Башкортостан - 13.

11 ранее судимых кандидатов баллотировалось на выборах депутатов Законодательного Собрания Забайкальского края и выборах депутатов Законодательного Собрания Владимирской области.

10 ранее судимых кандидатов участвовало в выборах народных депутатов Республики Саха, 8 - на выборах депутатов Народного Хурала Республики Бурятия, 7 - на выборах в Законодательное Собрание Ростовской области.

Менее заметное криминальное представительство было характерно для выдвижения и регистрации кандидатов в депутаты Народного Хурала Республики Калмыкия, Парламента Чеченской Республики и Архангельской областной Думы - по 3 кандидата соответственно. В Верховный Совет Республики Хакасия выдвигалось 2 гражданина с уголовным прошлым.

Максимальное количество представителей криминалитета на муниципальных выборах 8 сентября 2013 г. было зафиксировано в списках кандидатов в Екатеринбургскую городскую Думу - 7 человек - и Волгоградскую городскую Думу - 5 человек. В выборах в Архангельскую городскую Думу и Красноярский городской совет депутатов участвовало по 1 ранее судимому гражданину.

избирательных кампаний по выборам депутатов законодательных (представительных) органов государственной власти и органов местного самоуправления административных центров субъектов Российской Федерации в Единый день голосования 13 марта 2011 года. М.: ЦИК России, 2011. С. 394-396. 
Самая «чистая» в криминальном плане парламентская партия «ЕДИНАЯ РОССИЯ» выдвинула трех ранее судимых кандидатов, привлекавшихся к уголовной ответственности по ст. 206 УК РСФСР «злостное хулиганство», по ст. 158 УК РФ «кража» и ст. 286 УК РФ «превышение должностных полномочий» ${ }^{1}$.

В списках Коммунистической партии Российской Федерации было 6 ранее судимых граждан. Один из кандидатов был осужден по ст. 103 УК РСФСР за умышленное убийство, один - по ст. 158 УК РФ за кражу, один по ст. 315 УК РФ за неисполнение приговора суда, решения суда или иного судебного акта, один - по ст. 198 УК РФ за уклонение от уплаты налогов в особо крупном размере. Один из граждан, включенных в партийные списки, в прошлом занимавший государственную должность, был осужден по совокупности составов преступлений, предусмотренных ст.ст. 290 и 159 УК РФ, - за получение взятки и мошенничество. Данное лицо было освобождено из мест лишения свободы по амнистии.

Один кандидат в депутаты имел судимость по уголовному законодательству иностранного государства и также вышел на свободу по амнистии.

Политическая партия СПРАВЕДЛИВАЯ РОССИЯ выдвинула 16 кандидатов с уголовным прошлым. 8 кандидатов были осуждены за совершение преступлений против собственности («кража», «мошенничество», «разбой», «вымогательство»), 2 кандидата - за совершение преступлений против общественной безопасности («хулиганство»), 2 - за преступления в сфере экономической деятельности («уклонение от уплаты налогов»), 2 - за преступления против интересов государственной службы и службы в органах местного самоуправления («превышение должностных полномочий»), 2 - за преступления против безопасности движения и эксплуатации транспорта («нарушение правил дорожного движения и

\footnotetext{
1 Зарегистрированные списки указанной парламентской партии содержали наименьшее число лиц, привлекавшихся к уголовной ответственности и имеющих погашенные судимости.
} 
эксплуатации транспортных средств»), 1 - за преступление против порядка управления («применение насилия в отношении представителя власти»), 1 за совершение преступления против жизни и здоровья («побои»), 1 - за совершение преступления против семьи и несовершеннолетних («нарушение неисполнение обязанностей по воспитанию несовершеннолетних»).

От Либерально-демократической партии России баллотировались 13 ранее судимых граждан, в том числе 1 - неоднократно судимый, 1 - с неснятой (непогашенной) судимостью, 2 - осуждены по совокупности составов преступлений.

7 кандидатов привлекались к уголовной ответственности за совершение преступлений против собственности (1 - за присвоение или растрату, 1 - за мошенничество, 5 - за кражу). 2 кандидата подвергались уголовному преследованию за совершение преступлений против жизни и здоровья («побои», «умышленное причинение тяжкого вреда здоровью»). 2 кандидата были осуждены за совершение преступлений против порядка управления («подделка, изготовление или сбыт поддельных документов, государственных наград, штампов, печатей, бланков»). По одному кандидату имели судимость за преступления в сфере экономической деятельности («контрабанда»), преступления против здоровья населения и общественной нравственности («незаконное приобретение, хранение, перевозка, изготовление, переработка наркотических средств, психотропных веществ или их аналогов»), преступления против интересов службы в коммерческих и иных организациях («злоупотребление полномочиями», «коммерческий подкуп»).

В отношении 1 кандидата уголовное дело было прекращено вследствие акта об амнистии (пп.3 п.1 ст. 27 УПК РФ).

ПАТРИОТЫ РОССИИ выдвинули 7 кандидатов, имевших судимость. Все кандидаты привлекались к уголовной ответственности за совершение преступлений против собственности (3 - за кражу, 2 - за мошенничество, 1 - 
за присвоение или растрату, 1 - за вымогательство). 1 кандидат был осужден по совокупности составов.

В списках Российской объединенной демократической партии «ЯБЛОКО» присутствовали 5 кандидатов с уголовным прошлым. 4 кандидата были осуждены за совершение преступлений против собственности («кража», «мошенничество», «присвоение или растрата»), 1 кандидат - за совершение преступления против общественной безопасности («хулиганство»). 1 кандидат привлекался к уголовной ответственности по совокупности составов преступлений.

Необходимо отметить, что кампания по выборам в органы государственной власти субъектов Российской Федерации и органы местного самоуправления административных центров субъектов Российской Федерации 8 сентября 2013 г. проводилась в условиях значительного роста политической конкуренции. Согласно Федеральному закону от 11.07.2001 г. № 95-Ф3 (в редакции от 02.04.2012 г. № 28-Ф3) «О политических партиях» минимальная обязательная численность членов политической партии была снижена с 40 тысяч до 500 человек, что существенно упростило процедуру регистрации партий. В связи с этим заметно возросло количество субъектов выдвижения кандидатов на выборах в органы власти и местного самоуправления. Наряду с парламентскими партиями, допущенными к распределению депутатских мандатов в Государственной Думе Федерального Собрания Российской Федерации и законодательных органах власти субъектов Российской Федерации, в выборах приняли участие и недавно зарегистрированные политические партии.

Среди представителей 25 непарламентских партий распределение выдвинутых на выборах 8 сентября 2013 г. кандидатов с уголовным прошлым выглядит следующим образом: Гражданская Платформа - 7, Российская экологическая партия ЗЕЛЁНЫЕ - 5, Коммунисты России - 4, Коммунистическая партия социальной справедливости - 4, Российская партия пенсионеров за справедливость - 4, Родная Страна - 4, Родина - 4, 
Рожденные в Союзе Советских Социалистических Республик - 4, Аграрная партия России - 3, Трудовая партия России - 3, Альянс Зеленых - Народная партия - 3, Гражданская позиция - 2, Республиканская партия России Партия Народной Свободы - 2, Партия ЗА СПРАВЕДЛИВОСТЬ! - 2, Российский Общенародный Союз - 2, Партия Ветеранов России - 2. По одному ранее судимому кандидату выдвинули Партия Социальной солидарности, Российская политическая партия Мира и Единства, Объединенная аграрно-промышленная партия России, Города России, Социал-демократическая партия России, Демократическая партия России, Партия свободных граждан, Защитники Отечества и ЧЕСТНО / Человек. Справедливость. Ответственность.

B списках Гражданской Платформы было 3 осужденных за преступления против собственности («грабеж», «кража», «вымогательство»), 2 - за преступления против государственной власти, интересов государственной службы и службы в органах местного самоуправления («превышение должностных полномочий», «злоупотребление должностными полномочиями», «получение взятки»), по 1 кандидату - осужденному за преступление против общественной безопасности («хулиганство») и преступление против жизни и здоровья («умышленное причинение легкого вреда здоровью»).

Российская экологическая партия ЗЕЛЁНЫЕ выдвинула 5 ранее судимых кандидатов, 2 из которых были осуждены за преступления против государственной власти, интересов государственной службы и службы в органах местного самоуправления («получение взятки» и «превышение должностных полномочий»), 1 - за преступление в сфере экономической деятельности («незаконный оборот драгоценных металлов, природных драгоценных камней или жемчуга»), 1 - за преступление против здоровья и нравственности населения («незаконное приобретение, хранение, перевозка, изготовление, переработка наркотических средств, психотропных веществ 
или их аналогов»), 1 - за преступление против жизни и здоровья («побои»). 1 кандидат имел неоднократные судимости.

От партии Коммунисты России баллотировались 4 судимых кандидата, в том числе 1 - трижды судимый. 2 кандидата были осуждены за преступления против жизни и здоровья («побои»), 1 - за преступление против порядка управления («оскорбление представителя власти»), 1 - за преступление против военной службы («дезертирство»). Один из кандидатов имел судимости по совокупности совершенных преступлений («кража», «мошенничество» и «побои»).

В списках Коммунистической партии социальной справедливости присутствовали 4 кандидата с уголовным прошлым. 2 кандидата привлекались к уголовной ответственности за преступления против собственности («кража» и «разбой»), 1 - за преступление против здоровья и нравственности населения («незаконное приобретение, хранение, перевозка, изготовление, переработка наркотических средств, психотропных веществ или их аналогов»), 1 - за преступление против жизни и здоровья («умышленное причинение тяжкого вреда здоровью»). Один из претендентов на депутатский мандат имел судимости за хулиганство и незаконное приобретение, хранение, перевозку, изготовление, переработку наркотических средств, психотропных веществ или их аналогов.

Родная Страна выдвинула 4 ранее судимых кандидатов. 1 был осужден за преступление против государственной власти, интересов государственной службы и службы в органах местного самоуправления («получение взятки»), 1 - за преступление против собственности («кража»), 1 - за преступление против безопасности движения и эксплуатации транспорта («нарушение правил дорожного движения и эксплуатации транспортных средств»), 1 - за преступление против половой неприкосновенности и половой свободы личности («насильственные действия сексуального характера»).

Представители Родины привлекались к уголовной ответственности за совершение преступлений против государственной власти, интересов 
государственной службы и службы в органах местного самоуправления («получение взятки») - 1, против собственности («грабеж») - 1, против общественной безопасности («хулиганство») - 1, против порядка управления («уклонение от прохождения военной и альтернативной гражданской службы») - 1.

Рожденные в Союзе Советских Социалистических Республик выдвинули 3 кандидатов, имеющих судимость за совершение преступлений против собственности («кража», «мошенничество», «грабеж»). Один из кандидатов в депутаты законодательного органа государственной власти субъекта Российской Федерации был осужден по совокупности составов преступлений («подделка, изготовление или сбыт поддельных документов, государственных наград, штампов, печатей, бланков», «должностной подлог», «халатность», «злоупотребление властью или служебным положением» и «хищение государственного или общественного имущества путем мошенничества»).

От Аграрной партии России были выдвинуты 3 кандидата с уголовным прошлым. 1 кандидат был осужден за преступления против общественной безопасности («хулиганство», «незаконное ношение, хранение, приобретение, изготовление или сбыт оружия, боеприпасов или взрывчатых веществ»), 1 - за преступление против собственности («присвоение или растрата»), 1 - за преступление против порядка управления («подделка, изготовление или сбыт поддельных документов, государственных наград, штампов, печатей, бланков»). 1 из кандидатов был освобожден из мест лишения свободы по амнистии, 1 - освобожден от наказания в связи с истечением срока давности обвинительного приговора суда.

В списках Трудовой партии России находилось 3 гражданина, имеющих судимость (1 - за мошенничество, 1 - неоднократно судим за хулиганство, 1 - осужден по совокупности составов за кражу и незаконное ношение, хранение, приобретение, изготовление или сбыт оружия, боеприпасов или взрывчатых веществ). 
Альянс Зеленых - Народная партия выдвинул 3 ранее судимых кандидатов (1 - за кражу, 1 - за изнасилование, совершенное группой лиц, или изнасилование несовершеннолетней, 1 - находился в федеральном розыске за совершение преступления в сфере экономической деятельности).

Представители Гражданской позиции имели судимость за преступления против собственности («грабеж») и против конституционных прав и свобод человека и гражданина («нарушение авторских и смежных прав»).

В списках Республиканской партии России - Партии Народной Свободы баллотировалось 2 гражданина, осужденных за совершение преступлений против собственности («кража» и «грабеж»).

От Партии ЗА СПРАВЕДЛИВОСТЬ! выдвигались 2 гражданина, осужденных за дачу взятки и подделку, изготовление или сбыт поддельных документов, государственных наград, штампов, печатей, бланков, а также за превышение должностных полномочий.

Российский Общенародный Союз выдвинул кандидата, имевшего судимость за побои и умышленное уничтожение или повреждение имущества, а также кандидата, судимого за умышленное убийство.

1 представитель Партии Ветеранов России на выборах в законодательный орган государственной власти субъекта Российской Федерации привлекался к уголовной ответственности за захват заложника, 1 - имел несколько судимостей за присвоение или растрату с лишением права занимать должности в государственном органе.

За преступления в сфере экономической деятельности были осуждены кандидаты ЧЕСТНО / Человек. Справедливость. Ответственность и Объединенной аграрно-промышленной партии России («контрабанда» и «сокрытие денежных средств либо имущества организации или индивидуального предпринимателя, за счет которых должно производиться взыскание налогов и сборов»). Кандидаты Городов России и Демократической партии России привлекались к уголовной ответственности 
за совершение преступлений против жизни и здоровья («умышленное причинение легкого вреда здоровью» и «умышленное причинение тяжкого вреда здоровью»). При этом один из кандидатов имел на день выборов неснятую (непогашенную) судимость.

Неоднократно судимый представитель Российской политической партии Мира и Единства был в разное время осужден за хулиганство, истязание, умышленное тяжкое телесное повреждение, угрозу убийством, нанесением тяжких телесных повреждений или уничтожением имущества. Данный гражданин был освобожден из мест лишения свободы по амнистии.

Кандидат Партии свободных граждан подвергался уголовному преследованию за превышение должностных полномочий с лишением права заниматься деятельностью в качестве должностного лица.

Кандидат в депутаты законодательного органа государственной власти субъекта Российской Федерации от Защитников Отечества имел судимости за мошенничество и злоупотребление должностными полномочиями.

К уголовной ответственности за совершение преступлений против порядка управления привлекались кандидаты Партии Социальной солидарности и Социал-демократической партии России («самоуправство», «уклонение от прохождения военной и альтернативной гражданской службы» и «побои»).

В избирательной кампании по выборам в органы государственной власти субъектов Российской Федерации и органы местного самоуправления административных центров субъектов Российской Федерации 8 сентября 2013 г. приняло участие 6 ранее судимых кандидатов-самовыдвиженцев. 3 кандидата-самовыдвиженца были осуждены за совершение преступлений против собственности («кража», «разбой»), 2 - за совершение преступлений против конституционных прав и свобод человека и гражданина («необоснованный отказ в приеме на работу или необоснованное увольнение беременной женщины или женщины, имеющей детей в возрасте до 3 лет», «нарушение авторских и смежных прав»), 1 - за преступление против 
государственной власти, интересов государственной службы и службы в органах местного самоуправления («злоупотребление должностными полномочиями»), 1 - за преступление против общественной безопасности («незаконное ношение, хранение, приобретение, изготовление или сбыт оружия, боевых припасов или взрывчатых веществ») и 1 - за преступление против жизни и здоровья («умышленное причинение тяжкого вреда здоровью»). Два кандидата-самовыдвиженца привлекались к уголовной ответственности по совокупности составов преступлений.

Проведенный анализ списков зарегистрированных кандидатов на муниципальных и региональных выборах, состоявшихся 8 сентября 2013 г., свидетельствует о том, что среди ранее судимых кандидатов на выборах значительную долю составляют лица, осужденные за преступления против собственности. Данная категория граждан баллотировалась как в порядке самовыдвижения, так и в составе партийных списков.

В списках кандидатов от партий также наблюдается существенное криминальное представительство граждан, имеющих судимость за преступления против общественной безопасности, преступления против жизни и здоровья, преступления против государственной власти, интересов государственной службы и службы в органах местного самоуправления, преступления в сфере экономической деятельности и за преступления против порядка управления.

В зарегистрированных списках парламентских партий было включено 29 граждан, осужденных за совершение преступлений против собственности, 4 были осуждены за преступления против общественной безопасности, 4 - за преступления против жизни и здоровья, по 3 - за преступления против государственной власти, интересов государственной службы и службы в органах местного самоуправления, за преступления в сфере экономической деятельности и за преступления против порядка управления. По одному кандидату привлекались к уголовной ответственности за преступления против здоровья населения и общественной нравственности, за преступления 
против безопасности движения и эксплуатации транспорта, за преступления против семьи и несовершеннолетних, а также за преступления против интересов службы в коммерческих и иных организациях.

Распределение осужденных по составам преступлений в зарегистрированных списках непарламентских партий выглядит следующим образом: 20 граждан подвергались уголовному преследованию за совершение преступлений против собственности, 12 - за совершение преступлений против жизни и здоровья, 10 - за совершение преступлений против государственной власти, интересов государственной службы и службы в органах местного самоуправления. По 7 кандидатов имели судимость за преступления против порядка управления и против общественной безопасности. 4 кандидата привлекались к уголовной ответственности за преступления в сфере экономической деятельности, 3 - за преступления против здоровья населения и общественной нравственности, 2 - за преступления против половой неприкосновенности и половой свободы личности, по 1 кандидату - за преступления против военной службы, против безопасности дорожного движения и эксплуатации транспорта, против конституционных прав и свобод человека и гражданина ${ }^{1}$. Один из кандидатов находился в федеральном розыске.

В списках парламентских партий баллотировалось 43,8 \% от общего числа кандидатов, имеющих судимость. Доля судимых кандидатов, представляющих интересы недавно зарегистрированных партий, составила $56,1 \%$ от общего числа кандидатов, имеющих судимость. В составе зарегистрированных списков парламентских и непарламентских партий баллотировались граждане с неснятой (непогашенной) судимостью (по одному кандидату соответственно).

1 Необходимо учитывать два обстоятельства: 1) При подсчете составов неоднократность преступлений не принималась во внимание, состав преступления учитывался один раз; 2) Некоторые граждане были осуждены по совокупности составов преступлений. 
Для проникновения в органы государственной власти субъектов Российской Федерации и органы местного самоуправления представители криминалитета используют разнообразные ухищрения.

С целью получения депутатских мандатов в федеральном и региональных органах законодательной власти криминальные элементы сознательно искажают свои установочные данные (отчество, дату рождения), удаляют сведения о себе из региональных баз правоохранительных органов ${ }^{1}$, а также стремятся продвигать «незасвеченных» ставленников (нередко близких родственников), не имеющих судимостей и выявленных связей с организованной преступностью. Это затрудняет проверки указанных граждан по учетам ФГБУ «ГИАЦ МВД России» и информационных центров территориальных органов МВД России.

Некоторые ранее судимые кандидаты баллотируются на выборах в органы государственной власти и органы местного самоуправления субъектов Российской Федерации, в которых они постоянно не проживают.

Часть кандидатов оперативно меняет партийную принадлежность и баллотируется в списках другой партии.

Указание в качестве рода занятий «временно неработающий» иногда используется кандидатами, в отношении которых избрана мера пресечения в виде заключения под стражу (ст. 98 УПК РФ).

1 В ряде субъектов Российской Федерации отмечались факты, когда материалы оперативно-справочных учетов информационных центров МВД, ГУВД, УВД субъектов Российской Федерации искажались коррумпированными сотрудниками правоохранительных органов. 


\section{4. ОСНОВНЫЕ НАПРАВЛЕНИЯ ПРОТИВОДЕЙСТВИЯ КРИМИНАЛИЗАЦИИ ОРГАНОВ ПУБЛИЧНОЙ ВЛАСТИ В РОССИЙСКОЙ ФЕДЕРАЦИИ}

Сложившаяся в политической и социально-экономической системах криминогенная ситуация требует реагирования со стороны руководства государства, формирования и последовательной реализации более жесткой антикриминальной политики в Российской Федерации.

Правовые положения, направленные на противодействие криминализации органов власти, представлены в законодательных актах «О статусе члена Совета Федерации и статусе депутата Государственной Думы Федерального Собрания Российской Федерации», «О Правительстве Российской Федерации», «Об общих принципах организации законодательных (представительных) и исполнительных органов государственной власти субъектов Российской Федерации», «О государственной гражданской службе Российской Федерации», «О муниципальной службе в Российской Федерации», «О прокуратуре Российской Федерации», «О статусе судей в Российской Федерации», «О полиции», «О статусе военнослужащих», «О воинской обязанности и военной службе», «О противодействии коррупции», «О контроле за соответствием расходов лиц, замещающих государственные должности, и иных лиц их доходам», «О запрете отдельным категориям лиц открывать и иметь счета (вклады), хранить наличные денежные средства и ценности в иностранных банках, расположенных за пределами территории Российской Федерации, владеть и (или) пользоваться иностранными финансовыми инструментами» и др.

По направленности юридических предписаний правовую базу противодействия криминализации органов власти можно представить в виде системы антикоррупционных стандартов, нацеленных на выявление, предупреждение, пресечение, раскрытие и расследование коррупционных 
правонарушений, и антикриминальных правовых механизмов, ориентированных на противодействие проникновению представителей организованной преступности и лиц с уголовным прошлым в органы власти и управления, муниципальные институты.

По способам реализации применительно к тому или иному порядку формирования органов публичной власти следует различать антикриминальные правовые механизмы, связанные с назначением на должности и осуществлением определенной властной деятельности, а также антикриминальные механизмы, связанные с избранием на выборные должности и в представительные органы власти.

Как уже отмечалось, важнейшей составляющей противодействия сращивания организованной преступности с властными структурами выступает антикоррупционная деятельность государства и институтов гражданского общества.

Антикоррупционные стандарты можно рассматривать в нескольких аспектах:

- как элемент юридического состава, определяющего требования к назначению (избранию) на соответствующую должность, и требования к осуществлению определенной властной деятельности (исполнительнораспорядительной, депутатской, судопроизводству, гражданской, военной, муниципальной службе, службе в органах прокуратуры и полиции);

- как правопрекращающий юридический факт, выступающий основанием для досрочного прекращения полномочий члена Совета Федерации, депутата Государственной Думы Федерального Собрания Российской Федерации, высшего должностного лица субъекта Российской Федерации, депутатских полномочий, прекращения полномочий судьи, расторжения служебного контракта, трудового договора с муниципальным служащим, увольнения с гражданской и военной службы;

- как основание для привлечения к дисциплинарной ответственности за совершение коррупционных правонарушений; 
- как основание для временного отстранения от замещаемой должности (исполнения должностных обязанностей), приостановления полномочий и отставки судьи, перевода военнослужащего в распоряжение командира (начальника).

Антикоррупционные стандарты, определяющие требования к назначению (избранию) на соответствующую должность, и требования к осуществлению определенной властной деятельности (исполнительнораспорядительной, депутатской, судопроизводству, гражданской, военной, муниципальной службе, службе в органах прокуратуры и полиции, закреплены в статье 12.1 Федерального закона «О противодействии коррупции.

В соответствии с указанной статьей лица, замещающие государственные должности Российской Федерации, государственные должности субъектов Российской Федерации, муниципальные должности не вправе:

- заниматься предпринимательской или другой оплачиваемой деятельностью, кроме преподавательской, научной и иной творческой деятельности ${ }^{1}$;

- состоять членом органа управления хозяйственного общества или иной коммерческой организации;

- входить в состав органов управления, попечительских или наблюдательных советов, иных органов иностранных некоммерческих неправительственных организаций и действующих на территории Российской Федерации их структурных подразделений, если иное не предусмотрено международным договором Российской Федерации или законодательством Российской Федерации;

${ }^{1}$ При этом преподавательская, научная и иная творческая деятельность не может финансироваться исключительно за счет средств иностранных государств, международных и иностранных организаций, иностранных граждан и лиц без гражданства, если иное не предусмотрено международным договором или законодательством Российской Федерации. 
- получать в связи с осуществлением соответствующих полномочий не предусмотренные законодательством Российской Федерации вознаграждения (ссуды, денежное и иное вознаграждение, услуги, оплату развлечений, отдыха, транспортных расходов) от физических и юридических лиц;

- выезжать в связи с осуществлением соответствующих полномочий за пределы территории Российской Федерации за счет средств физических и юридических лиц, за исключением служебных командировок, осуществляемых в соответствии с законодательством Российской Федерации, международными договорами Российской Федерации или договоренностями на взаимной основе федеральных органов государственной власти, органов государственной власти субъектов Российской Федерации с государственными органами иностранных государств, международными и иностранными организациями;

- использовать в целях, не связанных с осуществлением соответствующих полномочий, средства материально-технического, финансового и информационного обеспечения, предназначенные для служебной деятельности;

- разглашать или использовать в целях, не связанных с осуществлением соответствующих полномочий, сведения, отнесенные в соответствии с федеральным законом к информации ограниченного доступа, или служебную информацию, ставшие ему известными в связи с осуществлением соответствующих полномочий;

- открывать и иметь счета (вклады), хранить наличные денежные средства и ценности в иностранных банках, расположенных за пределами территории Российской Федерации, владеть и (или) пользоваться иностранными финансовыми инструментами.

В случае возможного конфликта интересов в результате владения доходными ценными бумагами, акциями (долями участия в уставных капиталах организаций) должностное лицо-владелец обязано передать 
принадлежащие ему указанные ценные бумаги, акции (доли участия в уставных капиталах организаций) в доверительное управление ${ }^{1}$.

Аналогичные требования к назначению (избранию) на соответствующую должность, и требования к осуществлению публичной властной деятельности установлены в статье 6 Федерального закона «О статусе члена Совета Федерации и статусе депутата Государственной Думы Федерального Собрания Российской Федерации», статье 11 Федерального конституционного закона «О Правительстве Российской Федерации», статьях 12 и 18 Федерального закона «Об общих принципах организации законодательных (представительных) и исполнительных органов государственной власти субъектов Российской Федерации», статье 40 Федерального закона «Об общих принципах организации местного самоуправления в Российской Федерации», статье 16 Федерального закона «О государственной гражданской службе Российской Федерации», статье 13 Федерального закона «О муниципальной службе в Российской Федерации», статье 40.2 Закона Российской Федерации «О прокуратуре Российской Федерации», статье 3 Закона Российской Федерации «О статусе судей в Российской Федерации», статье 17 Федерального закона «О Следственном комитете Российской Федерации», статье 29 Федерального закона «О полиции», статье 10 Федерального закона «О статусе военнослужащих», статье 51 Федерального закона «О воинской обязанности и военной службе».

Федеральный закон «О противодействии коррупции» устанавливает обязанность граждан, претендующих на замещение должностей государственной или муниципальной службы, должностей в государственных корпорациях, должностей руководителей государственных

1 Под конфликтом интересов понимается ситуация, при которой личная заинтересованность должностного лица влияет или может повлиять на объективное исполнение им должностных обязанностей и при которой возникает или может возникнуть противоречие между личной заинтересованностью данного лица и законными интересами граждан, организаций, общества, государства, субъекта Российской Федерации, муниципального образования, способное привести к причинению вреда этим законным интересам. 
(муниципальных) учреждений, предоставлять работодателю сведения о своих доходах, об имуществе и обязательствах имущественного характера, а также о доходах, имуществе и обязательствах имущественного характера своих супруги (супруга) и несовершеннолетних детей.

В соответствии с Федеральным законом от 3 декабря 2012 г. № 230-Ф3 «О контроле за соответствием расходов лиц, замещающих государственные должности, и иных лиц, их расходам» установлена процедура контроля за расходами Президента Российской Федерации, членов Правительства Российской Федерации, членов Совета Федерации и депутатов Государственной Думы Федерального Собрания Российской Федерации, иных лиц, замещающих государственные должности Российской Федерации, судей, депутатов законодательных органов государственной власти субъектов Российской Федерации, иных лиц, замещающих государственные должности субъектов Российской Федерации, муниципальные должности на постоянной основе, должности федеральной государственной службы и государственной гражданской службы субъектов Российской Федерации, должности муниципальной службы. Контрольные мероприятия также проводятся в отношении их супругов и несовершеннолетних детей.

Указанные в законе лица обязаны отчитываться по каждой сделке, связанной с приобретением земельного участка, другого объекта недвижимости, транспортного средства, ценных бумаг, акций, долей участия, паев в уставных капиталах организаций, а также об источниках, за счет которых они были куплены. При этом сведения предоставляются, если расходы превысят общий доход лица и его супруги (супруга) по основному месту их службы (работы) за три года, предшествующих сделке. На период контрольных мероприятий проверяемое лицо может быть отстранено от должности. 
Данные антикоррупционные требования нашли свое отражение и в отраслевом законодательстве ${ }^{1}$.

Проверка достоверности сведений о доходах, расходах, имуществе и обязательствах имущественного характера осуществляется кадровыми службами государственных органов и должностными лицами кадровых служб, ответственными за работу по профилактике коррупционных и иных правонарушений. В некоторых государственных органах данные функции осуществляются специализированным подразделением.

По решению Президента Российской Федерации, Руководителя Администрации Президента Российской Федерации либо специально уполномоченного ими должностного лица Администрации Президента Российской Федерации Управление Президента Российской Федерации по вопросам государственной службы и кадров может в установленном порядке осуществлять проверку достоверности и полноты сведений о доходах, расходах, об имуществе и обязательствах имущественного характера, представляемых гражданами, претендующими на замещение любых должностей, осуществление полномочий по которым влечет за собой обязанность представлять сведения о доходах, об имуществе и обязательствах имущественного характера, а также достоверности и полноты иных сведений, представляемых указанными гражданами.

В качестве примера можно привести проверку достоверности и полноты сведений о гражданах, претендующих на замещение должности высшего должностного лица субъекта Российской Федерации.

${ }^{1}$ Статья 10 Федерального закона «О статусе члена Совета Федерации и статусе депутата Государственной Думы Федерального Собрания Российской Федерации», статья 10 Федерального конституционного закона «О Правительстве Российской Федерации», статья 12 Федерального закона «Об общих принципах организации законодательных (представительных) и исполнительных органов государственной власти субъектов Российской Федерации», статья 20 Федерального закона «О государственной гражданской службе Российской Федерации», статья 15 Федерального закона «О муниципальной службе в Российской Федерации», статья 40.2 Закона Российской Федерации «О прокуратуре Российской Федерации», статья 8.1 Закона Российской Федерации «О статусе судей в Российской Федерации», статья 29 Федерального закона «О полиции», статья 27.1 Федерального закона «О статусе военнослужащих». 
Так, в связи с изменением порядка наделения полномочиями высшего должностного лица субъекта Российской Федерации Федеральный закон «О политических партиях» был дополнен статьей 26.3. В соответствии с данной статьей политические партии, списки кандидатов которых были допущены к распределению депутатских мандатов, вправе вносить Президенту Российской Федерации предложения о кандидатурах на должность высшего должностного лица субъекта Российской Федерации. Вместе с предложениями политические партии представляют Президенту Российской Федерации по каждой кандидатуре:

- заявление выдвигаемого лица о согласии на выдвижение его кандидатом ${ }^{1}$;

- копию паспорта или документа, заменяющего паспорт гражданина;

- копии документов, подтверждающих указанные в заявлении сведения об образовании, основном месте работы или службы, о занимаемой должности (роде занятий), а также о том, что выдвинутое лицо является депутатом;

- сведения о размере и об источниках доходов выдвинутого лица, а также об имуществе, принадлежащем выдвинутому лицу на праве собственности (в том числе совместной собственности), о вкладах в банках, ценных бумагах;

- сведения о размере и об источниках доходов, об имуществе, о вкладах в банках, ценных бумагах супруга (супруги) и несовершеннолетних детей выдвинутого лица;

- сведения о принадлежащем выдвинутому лицу, его супругу (супруге) и несовершеннолетним детям недвижимом имуществе, находящемся за

${ }^{1}$ В заявлении указываются фамилия, имя, отчество, дата и место рождения, адрес места жительства, серия, номер и дата выдачи паспорта или документа, заменяющего паспорт гражданина, наименование или код органа, выдавшего паспорт или документ, заменяющий паспорт гражданина, гражданство, образование, основное место работы или службы, занимаемая должность (в случае отсутствия основного места работы или службы - род занятий) выдвинутого лица. 
пределами территории Российской Федерации, об источниках получения средств, за счет которых приобретено указанное имущество, об обязательствах имущественного характера за пределами территории Российской Федерации выдвинутого лица, а также сведения о таких обязательствах его супруга (супруги) и несовершеннолетних детей ${ }^{1}$;

- сведения о расходах выдвинутого лица, его супруга (супруги) и несовершеннолетних детей по каждой сделке по приобретению земельного участка, другого объекта недвижимости, транспортного средства, ценных бумаг, акций (долей участия, паев в уставных (складочных) капиталах организаций), совершенной в течение последних трех лет, если сумма сделки превышает общий доход выдвинутого лица и его супруга (супруги) за три последних года, предшествующих совершению сделки, и об источниках получения средств, за счет которых совершена сделка.

Выдвинутое лицо обязано к моменту внесения его кандидатуры Президенту Российской Федерации закрыть счета (вклады), прекратить хранение наличных денежных средств и ценностей в иностранных банках, расположенных за пределами территории Российской Федерации, и (или) осуществить отчуждение иностранных финансовых инструментов.

В случае наличия у выдвинутого лица судимости в заявлении также указываются сведения о судимости ${ }^{2}$.

1 Указ Президента Российской Федерации от 6 июня 2013 г. № 546 «О проверке достоверности сведений об имуществе и обязательствах имущественного характера за пределами территории Российской Федерации, о расходах по каждой сделке по приобретению объектов недвижимости, транспортных средств, ценных бумаг и акций, представляемых кандидатами на выборах в органы государственной власти, выборах глав муниципальных районов и глав городских округов, а также политическими партиями в связи с внесением Президенту Российской Федерации предложений о кандидатурах на должность высшего должностного лица (руководителя высшего исполнительного органа государственной власти) субъекта Российской Федерации» // Рос. газ. 2013. 11 июня.

${ }^{2}$ Как указал Конституционный Суд Российской Федерации в Постановлении от 19 марта 2003 г. № 3-П «По делу о проверке конституционности положений Уголовного кодекса Российской Федерации, регламентирующих правовые последствия судимости лица, неоднократности и рецидива преступлений, а также пунктов 1-8 постановления Государственной Думы Федерального Собрания Российской Федерации от 26 мая 2000 г. «Об объявлении амнистии в связи с 55-летием Победы в Великой Отечественной Войне 1941-1945 годов» в связи с запросом Останкинского межмуниципального (районного) суда города Москвы и жалобами ряда граждан», «судимость представляет собой правовое состояние лица, обусловленное фактом осуждения и назначения ему по приговору суда наказания за совершенное преступление» // Рос. Газ. 2003. 2 апреля. 
В Приказе МВД России от 7 ноября 2011 г. № 1121 «Об утверждении Административного регламента Министерства внутренних дел Российской Федерации по предоставлению государственной услуги по выдаче справок о наличии (отсутствии) судимости и (или) факта уголовного преследования либо о прекращении уголовного преследования» определен порядок получения справки о наличии (отсутствии) судимости и (или) факта уголовного преследования и перечень соответствующих сведений, содержащихся в данном документе.

При наличии имеющейся судимости, а также снятой и погашенной судимости - в графе «Имеются (не имеются) сведения о судимости (в том числе погашенной и снятой) на территории Российской Федерации» указывается дата осуждения, наименование суда, вынесшего приговор, пункт, часть, статья УК РФ, Уголовного кодекса РСФСР, республики Союза ССР, на основании которых лицо было осуждено, срок и вид наказания, дата освобождения, основания погашения или снятия судимости;

- при наличии факта уголовного преследования либо прекращения уголовного преследования по основаниям, предусмотренным п. 3,4 ч. 1 ст. 24 , ст. 25 , п. 3 ч. 1 ст. 27 , ст. 28 , ст. 28.1 , ч. 1 ст. 427 , ч. 1 ст. 443 , ч. 2 ст. 443 УПК РФ - в графе «Имеются (не имеются) сведения о факте уголовного преследования либо о прекращении уголовного преследования на территории Российской Федерации» указывается дата возбуждения уголовного дела, наименование органа, принявшего решение, пункт, часть, статья УК РФ, дата и основание прекращения уголовного дела (уголовного преследования);

- при установлении факта нахождения проверяемого лица в розыске за совершение преступления на территории Российской Федерации в графе «Дополнительная информация» указывается дата объявления в розыск, орган, принявший решение, а также пункт, часть, статья УК РФ, на основании которых проверяемое лицо привлекается к уголовной ответственности. 
Проверку достоверности и полноты соответствующих сведений о кандидатах на должность высшего должностного лица субъекта Российской Федерации также осуществляет Управление Президента Российской Федерации по вопросам государственной службы и кадров с использованием возможностей уполномоченных государственных органов.

Проверка достоверности и полноты сведений о доходах, об имуществе и обязательствах имущественного характера, представляемых гражданами, претендующими на замещение должностей федеральной государственной службы, назначение на которые и освобождение от которых осуществляются Правительством Российской Федерации, а также сведений, представляемых указанными гражданами; достоверности и полноты сведений о доходах, об имуществе и обязательствах имущественного характера, представляемых названными государственными служащими, замещающими должности федеральной государственной службы; соблюдения указанными государственными служащими требований к служебному поведению проводится по решению Руководителя Аппарата Правительства Российской Федерации, члена президиума Совета при Президенте Российской Федерации по противодействию коррупции специализированным подразделением Аппарата Правительства Российской Федераџии ${ }^{l}$.

В законодательных (представительных) органах государственной власти проверки достоверности и полноты сведений о доходах, расходах, имуществе и обязательствах имущественного характера проводят уполномоченные комиссии.

На основании статьи 10 Федерального закона «О статусе члена Совета Федерации и статусе депутата Государственной Думы Федерального Собрания Российской Федерации» член Совета Федерации и депутат Государственной Думы Федерального Собрания Российской Федерации

1 Указ Президента Российской Федерации от 18 мая 2009 г. № 559 «О представлении гражданами, претендующими на замещение должностей федеральной государственной службы, и федеральными государственными служащими сведений о доходах, об имуществе и обязательствах имущественного характера» // Рос. газ. 2009. 20 мая. 
должен ежегодно представлять в специализированную комиссию палаты Федерального Собрания Российской Федерации сведения о своих доходах, расходах, об имуществе и обязательствах имущественного характера, а также сведения о доходах, расходах, об имуществе и обязательствах имущественного характера своих супруги (супруга) и несовершеннолетних детей. Данная парламентская комиссия по информации правоохранительных органов, руководящих органов политических партий и общественных объединений, СМИ проводит проверку: достоверности и полноты сведений о доходах, расходах, об имуществе и обязательствах имущественного характера, представляемых депутатами; соблюдения депутатами ограничений и запретов, установленных действующим законодательством.

Независимо от парламентской комиссионной проверки по решению Президента Российской Федерации, Руководителя Администрации Президента Российской Федерации либо специально уполномоченного ими должностного лица Администрации Президента Российской Федерации аналогичные проверки может осуществлять Управление Президента Российской Федерации по вопросам государственной службы и кадров.

Информация о представлении депутатом заведомо недостоверных или неполных сведений о доходах, расходах, об имуществе и обязательствах имущественного характера, выявленных комиссией, подлежит опубликованию в официальном печатном издании Федерального Собрания Российской Федерации и размещению на официальном сайте соответственно Совета Федерации и Государственной Думы.

Похожий порядок представления сведений и проведения их проверки предусмотрен статьей 12 Федерального закона «Об общих принципах организации законодательных (представительных) и исполнительных органов государственной власти субъектов Российской Федерации».

На основании статьи 8.3 Закона Российской Федерации «О статусе судей в Российской Федерации» сведения о доходах, имуществе и обязательствах имущественного характера судьи представляют в суд, в 
котором они замещают свою должность. По решению Президента Российской Федерации, Руководителя Администрации Президента Российской Федерации либо специально уполномоченного ими должностного лица Администрации Президента Российской Федерации Управление Президента Российской Федерации по вопросам государственной службы и кадров может в установленном порядке осуществлять проверку достоверности и полноты сведений о доходах, расходах, об имуществе и обязательствах имущественного характера, представляемых судьями.

7 мая 2013 г. был принят Федеральный закон «О запрете отдельным категориям лиц открывать и иметь счета (вклады), хранить наличные денежные средства и ценности в иностранных банках, расположенных за пределами территории Российской Федерации, владеть и (или) пользоваться иностранными финансовыми инструментами». Данный закон направлен на обеспечение национальной безопасности и повышение эффективности противодействия коррупции путем установления запрета лицам, принимающим по долгу службы решения, затрагивающие вопросы суверенитета и национальной безопасности Российской Федерации, открывать и иметь счета (вклады), хранить наличные денежные средства и ценности в иностранных банках, расположенных за пределами территории Российской Федерации, владеть или пользоваться иностранными финансовыми инструментами. К указанной категории отнесены лица, замещающие государственные должности Российской Федерации, должности федеральной государственной службы, назначение на которые и освобождение от которых осуществляются Президентом Российской Федерации, Правительством Российской Федерации, должности заместителей руководителей федеральных органов исполнительной власти, глав городских округов, глав муниципальных районов и ряд других должностей. Кроме того, установлен порядок осуществления проверки 
соблюдения указанными лицами данного запрета и меры ответственности за его нарушение.

Антикоррупционные стандарты сформулированы в российском законодательстве и как правопрекращающий юридический факт, выступающий основанием для досрочного прекращения полномочий члена Совета Федерации, депутата Государственной Думы Федерального Собрания Российской Федерации, высшего должностного лица субъекта Российской Федерации, депутатских полномочий, прекращения полномочий судьи, расторжения служебного контракта, трудового договора с муниципальным служащим, увольнения с гражданской и военной службы.

Так, невыполнение должностным лицом обязанности предоставлять сведения о доходах, расходах, имуществе и обязательствах имущественного характера; предоставление заведомо недостоверных или неполных сведений; наличие счетов (вкладов) в иностранных банках за пределами территории Российской Федерации, владение или пользование иностранными финансовыми инструментами влекут освобождение от замещаемой (занимаемой должности), увольнение с гражданской, военной и муниципальной службы ${ }^{1}$.

Развивая данные положения, статья 4 Федерального закона «О статусе члена Совета Федерации и статусе депутата Государственной Думы Федерального Собрания Российской Федерации» предусматривает досрочное прекращение полномочий члена Совета Федерации и депутата Государственной Думы в случае открытия (наличия) счетов (вкладов), хранения наличных денежных средств и ценностей в иностранных банках,

1 Статьи 36 и 74.1 Федерального закона «Об общих принципах организации местного самоуправления в Российской Федерации», статьи 20, 20.1, 59.2 Федерального закона «О государственной гражданской службе Российской Федерации», статьи 15, 19, 27.1 Федерального закона «О муниципальной службе в Российской Федерации», статья 43 Закона Российской Федерации «О прокуратуре Российской Федерации», статья 14 Закона Российской Федерации «О статусе судей в Российской Федерации», статья 16 Федерального закона «О Следственном комитете Российской Федерации», статья 29 Федерального закона «О полиции», статья 51 Федерального закона «О воинской обязанности и военной службе», статья 27.1 Федерального закона «О статусе военнослужащих». 
расположенных за пределами территории Российской Федерации, владения и (или) пользования иностранными финансовыми инструментами членом Совета Федерации, депутатом Государственной Думы, их супругами и несовершеннолетними детьми.

В соответствии с п. 3.9 статьи 12 Федерального закона «Об общих принципах организации законодательных $\quad$ (представительных) и исполнительных органов государственной власти субъектов Российской Федерации» установление в отношении депутата, избранного по одномандатному или многомандатному избирательному округу, или депутата, избранного в составе списка кандидатов политической партии, фактов открытия или наличия счетов (вкладов), хранения наличных денежных средств и ценностей в иностранных банках, расположенных за пределами территории Российской Федерации, владения и (или) пользования иностранными финансовыми инструментами в период, когда он был зарегистрирован в качестве кандидата на соответствующих выборах, является основанием для досрочного прекращения депутатских полномочий.

Согласно п. 6.1 статьи 36 Федерального закона «Об общих принципах организации местного самоуправления в Российской Федерации» полномочия главы муниципального района, главы городского округа прекращаются досрочно в связи с утратой доверия Президента Российской Федерации в случаях:

1) несоблюдения главой муниципального района, главой городского округа, их супругами и несовершеннолетними детьми запрета, установленного Федеральным законом «О запрете отдельным категориям лиц открывать и иметь счета (вклады), хранить наличные денежные средства и ценности в иностранных банках, расположенных за пределами территории Российской Федерации, владеть и (или) пользоваться иностранными финансовыми инструментами»;

2) установления в отношении избранных на муниципальных выборах главы муниципального района, главы городского округа факта открытия или 
наличия счетов (вкладов), хранения наличных денежных средств и ценностей в иностранных банках, расположенных за пределами территории Российской Федерации, владения и (или) пользования иностранными финансовыми инструментами в период, когда указанные лица были зарегистрированы в качестве кандидатов на выборах соответственно главы муниципального района, главы городского округа.

Статья 74.1 Федерального закона «Об общих принципах организации местного самоуправления в Российской Федерации» устанавливает правовой режим удаления главы муниципального образования в отставку. Одним из оснований правореализации данного режима выступает несоблюдение ограничений и запретов и неисполнение обязанностей, предусмотренных Федеральным законом «О противодействии коррупции».

Рассмотрев антикоррупционные стандарты как правопрекращающий юридический факт, проанализируем коррупционные правонарушения в качестве основания для привлечения к дисциплинарной ответственности.

Согласно статье 59.3 Федерального закона «О государственной гражданской службе Российской Федерации» взыскания за коррупционные правонарушения налагаются на основании доклада специализированного подразделения кадровой службы государственного органа или на основании рекомендации комиссии по урегулированию конфликта интересов. Срок наложения взыскания не должен превышать 6 месяцев со дня поступления информации о совершении коррупционного правонарушения.

Законодателем предусмотрен административный (в комиссию по служебным спорам) или судебный порядок обжалования взыскания.

Аналогичный порядок привлечения к дисциплинарной ответственности закреплен в статье 51.1 Федерального закона «О воинской обязанности и военной службе», а также в статье 27.1 Федерального закона «О муниципальной службе в Российской Федерации».

Следует констатировать, что потенциал антикоррупционных стандартов не реализуется в полной мере, поскольку в законодательных 
актах Российской Федерации присутствуют некоторые полумеры и антикоррупционные «послабления» в отношении ряда должностных лиц.

Во-первых, сведения о доходах, расходах, имуществе и обязательствах имущественного характера обязаны представлять не все чиновники, а только граждане, претендующие на замещение должностей гражданской и муниципальной службы, включенных в перечень, установленный нормативными правовыми актами Российской Федерации, а также гражданские и муниципальные служащие, замещающие должности из данного перечня.

Во-вторых, требования Федерального закона от 3 декабря 2012 г. № 230-Ф3 по расходам должностных лиц о каждой сделке, связанной с приобретением земельного участка, другого объекта недвижимости, транспортного средства, ценных бумаг, акций, долей участия, паев в уставных капиталах организаций, а также об источниках, за счет которых они были куплены, предполагают возможность неограниченного количества сделок и непредставления должностным лицом отчетности, если расходы превысят общий доход лица и его супруги (супруга) по основному месту их службы (работы) за три года, предшествующих сделке ${ }^{1}$

Во-третьих, антикоррупционные ограничения в отношении вкладов должностных лиц в иностранных банках и иностранных финансовых инструментов распространяются только на лиц, замещающих государственные должности Российской Федерации, должности федеральной государственной службы, назначение на которые и освобождение от которых осуществляются Президентом Российской Федерации, Правительством Российской Федерации, должности заместителей руководителей федеральных органов исполнительной власти, глав городских округов, глав муниципальных районов и ряд других должностей из соответствующего перечня.

${ }^{1}$ Должностные лица в целях уклонения от контрольных мероприятий прибегают к различным ухищрениям: оформляют фиктивный развод, регистрируют имущественные права на других родственников (бабушек, дедушек) и т.д. 
При этом установленные законом ограничения никак не затрагивают финансовой основы коррупционной деятельности - возможности беспрепятственно выводить денежные средства за пределы территории Российской Федерации и вкладывать их в недвижимое имущество за рубежом.

В-четвертых, антикоррупционные стандарты содержат различные подходы к оценке материального положения, источников доходов, законности и прозрачности расходов отдельных должностных лиц и правовым последствиям конфликта интересов у данных лиц, непредставления этими должностными лицами сведений о доходах, расходах, имуществе и обязательствах имущественного характера в установленные сроки, а также представления заведомо недостоверных или неполных сведений.

Так, в статьях 9-11 Федерального конституционного закона «О Правительстве Российской Федерации» в перечне оснований освобождения от должности заместителей Председателя Правительства Российской Федерации и федеральных министров отсутствуют: выявление фактов коррупции, неурегулирование конфликта интересов, непредставление сведений о своих доходах, расходах, об имуществе и обязательствах имущественного характера, а также о доходах, расходах, имуществе и обязательствах имущественного характера своих супруги (супруга) и несовершеннолетних детей либо представление заведомо недостоверных или неполных сведений.

В статье 19 Федерального закона «Об общих принципах организации законодательных (представительных) и исполнительных органов государственной власти субъектов Российской Федерации» среди оснований досрочного прекращения полномочий высшего должностного лица субъекта Российской Федерации не предусмотрено непредставление сведений о своих доходах, расходах, об имуществе и обязательствах имущественного характера, а также о доходах, расходах, имуществе и обязательствах 
имущественного характера своих супруги (супруга) и несовершеннолетних детей либо представление заведомо недостоверных или неполных сведений.

В пункте 5 статьи 8.1 Закона Российской Федерации «О статусе судей в Российской Федерации» закреплено, что в случае непредставления сведений о доходах, расходах, имуществе и обязательствах имущественного характера в установленные сроки, а также представления заведомо недостоверных сведений судья может быть привлечен к дисциплинарной ответственности.

Получается, что сотрудники правоохранительных органов, военнослужащие, гражданские и муниципальные служащие подлежат в этом случае увольнению со службы, а названные должностные лица - продолжат исполнять свои обязанности и замещать должность. Более того, закон предполагает лишь возможность привлечения судей к ответственности, а ответственность за представление заведомо неполных сведений вовсе не предусмотрена. О неотвратимости применения юридических санкций также речи не идет.

Вопросы ответственности судей за коррупционные проступки и неурегулирование конфликта интересов актуализируют задачу пересмотра порядка привлечения судей к юридической ответственности. Однако в связи с тем, что квалификационные коллегии судей крайне редко реагирует на злоупотребления судейскими полномочиями, а оценка фактов неэтичного и противоправного использования судьями своего судейского статуса отдана на усмотрение квалификационных судейских коллегий, которые зачастую руководствуются корпоративными интересами, процесс очищения судейского сообщества от коррупционеров происходит крайне медленно1.

Представляется, что подобные формулировки необходимо привести в соответствие с едиными требованиями антикоррупционных стандартов. Ни для членов Правительства Российской Федерации, ни для высших должностных лиц субъектов Российской Федерации, ни для судей не должно

1 Дамаскин О.В. Коррупция: состояние, причины, противодействие. М.: Триумфальная арка, 2009. С. 42. 
быть исключений в вопросах прозрачности материального положения, источников их доходов, законности расходов и безупречной репутации.

Рассмотрим антикриминальные правовые механизмы, определяющие требования к назначению на соответствующую должность и осуществлению определенной властной деятельности (исполнительно-распорядительной, депутатской, судопроизводству, гражданской, военной, муниципальной службе, службе в органах прокуратуры и полиции).

Как правило, к числу обстоятельств, исключающих назначение на должность и прохождение гражданской, военной, правоохранительной и муниципальной службы, относятся:

- наличие судимости;

- осуждение лица к наказанию, исключающему возможность исполнения должностных обязанностей по приговору суда, вступившему в законную силу;

- представление подложных документов или заведомо ложных сведений при поступлении на службу, назначении на должность.

Речь может идти как о любой судимости, так и о неснятых и непогашенных судимостях.

Состояние судимости носит срочный характер. Судимость возникает при осуждении лица за совершение преступления со дня вступления обвинительного приговора суда в законную силу до момента погашения или снятия. Судимость учитывается при рецидиве преступлений и при назначении наказания.

Погашение судимости - автоматическое прекращение ее действия после истечения установленного законом срока.

В соответствии с ч.2 статьи 86 УК РФ судимость погашается:

а) в отношении лиц, условно осужденных, - по истечении испытательного срока; 
б) в отношении лиц, осужденных к более мягким видам наказания, чем лишение свободы, - по истечении одного года после отбытия или исполнения наказания;

в) в отношении лиц, осужденных к лишению свободы за преступления небольшой или средней тяжести, - по истечении трех лет после отбытия наказания;

г) в отношении лиц, осужденных к лишению свободы за тяжкие преступления, - по истечении восьми лет после отбытия наказания;

д) в отношении лиц, осужденных за особо тяжкие преступления, - по истечении десяти лет после отбытия наказания.

Если осужденный был досрочно освобожден от отбывания наказания или неотбытая часть наказания была заменена более мягким видом наказания, то срок погашения судимости исчисляется исходя из фактически отбытого срока наказания с момента освобождения от отбывания основного и дополнительного видов наказания.

При совершении лицом нескольких преступлений сроки погашения судимости исчисляются по каждому преступлению отдельно.

Погашение судимости не требует ходатайства лица и мотивированного постановления судьи.

Снятие судимости, в отличие от погашения, производится до истечения срока погашения судимости при условии безупречного поведения осужденного и с обязательным вынесением постановления судьи по данному вопросу.

Помимо снятия судимости по ходатайству лица Уголовный закон (ч.2 ст. 84 и ч.2 ст. 85 УК РФ) предусматривает снятие судимости с лиц, отбывших наказание, актом об амнистии или актом помилования.

Правовые последствия судимости позволяют предъявлять строгие требования к возможному криминальному прошлому лиц, претендующих на замещение должностей судей, прокуроров, полицейских и сотрудников спецслужб. 
Согласно пункту 1 статьи 4 Закона Российской Федерации «О статусе судей в Российской Федерации», пункту 2 статьи 40.1 Закона Российской Федерации «О прокуратуре Российской Федерации», пунктам 2 и 3 части 1 статьи 29 Федерального закона «О полиции», подпункту 4 пункта 5 статьи 18 Федерального закона «О государственной охране», пункту «в» части 3 статьи 16 Федерального закона «О федеральной службе безопасности», пункту 2 части 4 статьи 16 Федерального закона «О Следственном комитете Российской Федерации» гражданин, имеющий судимость (в том числе снятую или погашенную), а также в отношении которого уголовное преследование прекращено за истечением срока давности, в связи с примирением сторон, вследствие акта об амнистии или в связи с деятельным раскаянием, никогда не сможет поступить на службу или на работу в органы прокуратуры, полиции, органы государственной охраны, федеральной службы безопасности, следственные органы, не может быть назначен на должность судьи.

Данные требования представляются логичными.

Ведь ни у кого не вызывает возражений запрет на трудовую деятельность в сфере образования, воспитания, развития несовершеннолетних, организации их отдыха и оздоровления, медицинского обеспечения, социальной защиты и социального обслуживания, в сфере детско-юношеского спорта, культуры и искусства с участием несовершеннолетних граждан, имеющих или имевших судимость, подвергающихся или подвергавшихся уголовному преследованию (за исключением лиц, уголовное преследование в отношении которых прекращено по реабилитирующим основаниям) за преступления против жизни и здоровья, свободы, чести и достоинства личности (за исключением незаконного помещения в психиатрический стационар, клеветы и оскорбления), половой неприкосновенности и половой свободы личности, против семьи и несовершеннолетних, здоровья населения и общественной нравственности, основ конституционного строя и безопасности! 
В соответствии со статьей 351.1 Трудового кодекса Российской Федерации для всех перечисленных выше лиц наличие справки о наличии либо отсутствии судимости является обязательным документом для заключения трудового договора.

Вместе с тем отечественное законодательство формулирует более мягкие требования к гражданским служащим, членам избирательных комиссий, адвокатам и военнослужащим по призыву.

Согласно статье 16 Федерального закона «О государственной гражданской службе Российской Федерации» граждане со снятой или погашенной судимостью могут быть приняты на гражданскую службу и проходить ее.

Подпункт «н» пункта 1 статьи 29 Федерального закона «Об основных гарантиях избирательных прав и права на участие в референдуме граждан Российской Федерации» позволяет ранее судимым гражданам быть членами избирательных комиссий.

Лица с криминальным прошлым вправе претендовать на приобретение статуса адвоката и осуществление адвокатской деятельности (п.2 ч.2 ст.9 Федерального закона «Об адвокатской деятельности и адвокатуре в Российской Федерации»).

В соответствии с пунктом 3 статьи 23 Федерального закона «О воинской обязанности и военной службе» граждане, имеющие снятую или погашенную судимость, подлежат призыву на военную службу.

Граждане, лишенные воинского звания, после снятия или погашения судимости могут быть восстановлены в прежнем воинском звании должностным лицом, имеющим право присваивать это воинское звание. Федеральный закон от 28 марта 1998 г. № 53-Ф3 «О воинской обязанности и военной службе» прямо не указывает на возможность восстановления в воинских званиях, утраченных во внесудебном порядке. Пункт 2 его статьи 48 устанавливает, что гражданин, лишенный воинского звания, после снятия или погашения судимости может быть восстановлен в прежнем воинском 
звании должностным лицом, имеющим право присваивать это воинское звание, по просьбе гражданина при наличии положительного отзыва органа внутренних дел и решения комиссии военного комиссариата.

Интерпретация приведенных нормативных положений в взаимосвязи, при которой для лиц, лишенных за совершение проступка воинского звания во внесудебном порядке на основании действовавших до принятия названного Федерального закона норм, возможность быть восстановленными в воинском звании исключается, ставило бы их в худшее положение по сравнению с лицами, лишенными воинского звания по приговору суда за совершение тяжких и особо тяжких преступлений, для которых такая возможность предусмотрена. Подобный подход нарушал бы гарантированный статьей 19 Конституции Российской Федерации принцип равенства. Соответственно, невозможность для гражданина добиваться снятия ограничений в правах, идентичных тем, которые являются последствиями вынесенного судом приговора, на том только основании, что он был подвергнут им во внесудебном порядке, ставит его в заведомо худшее положение по сравнению с лицами, чьи права и свободы были ограничены по решению суда. Подобная дифференциация не имеет объективного и разумного оправдания и не преследует конституционно значимые цели ${ }^{1}$.

Исходя из изложенного, в своем Определении от 2 апреля 2009 г. № 483-О-П «По жалобе гражданина Цыганкова Бориса Викторовича на нарушение его конституционных прав пунктом 2 статьи 48 Федерального закона «О воинской обязанности и военной службе» и пунктом 1 статьи 25 Положения о порядке прохождения военной службы» Конституционный Суд Российской Федерации пришел к выводу, что «в системе действующего правового регулирования пункт 2 статьи 48 Федерального закона «О воинской обязанности и военной службе» и пункт 1 статьи 25 Положения о

${ }^{1}$ Определение Конституционного Суда Российской Федерации от 2 апреля 2009 г. № 483-О-П «По жалобе гражданина Цыганкова Бориса Викторовича на нарушение его конституционных прав пунктом 2 статьи 48 Федерального закона «О воинской обязанности и военной службе» и пунктом 1 статьи 25 Положения о порядке прохождения военной службы» // Вестник Конституционного Суда Российской Федерации. 2007. № 1. 
порядке прохождения военной службы не могут являться препятствием для восстановления в прежнем воинском звании лиц, лишенных воинского звания во внесудебном порядке» ${ }^{1}$.

Требования, исключающие назначение на должность и прохождение того или иного вида службы могут дифференцироваться в зависимости от осуждения лица к определенному виду наказания.

В конструкциях соответствующих статей федеральных законов встречаются различные формулировки: «осуждение лица к наказанию, исключающему возможность исполнения должностных обязанностей по должности государственной службы (гражданской службы), по приговору суда, вступившему в законную силу» (п.2 ч.1 ст. 16 Федерального закона «О государственной гражданской службе Российской Федерации»), «осуждение к наказанию, исключающему возможность исполнения должностных обязанностей по должности муниципальной службы, по приговору суда, вступившему в законную силу» (п.2 ч.1 ст. 13 Федерального закона «О муниципальной службе в Российской Федерации»), «осуждение к наказанию, исключающему возможность замещения должности гражданской службы, по приговору суда, вступившему в законную силу» (п.1 ч.2 ст. 37 Федерального закона «О государственной гражданской службе Российской Федерации»), «назначение наказания в виде лишения свободы» (п. 3 ст. 50, пп. «е» п. 1 ст. 51 Федерального закона «О воинской обязанности и военной службе»), «назначение наказания в виде лишения права занимать воинские должности в течение определенного срока» (пп. «з» п. 1 ст. 51 Федерального закона «О воинской обязанности и военной службе»), «назначение наказания в виде лишения лица права занимать определенные должности гражданской службы или заниматься определенной деятельностью» (п.1 ч.1 ст. 40 Федерального закона «О государственной гражданской службе Российской Федерации»), «лишение права занимать государственные должности государственной службы в течение определенного срока» (ч.2 ст. 40.1 Закона Российской

\footnotetext{
${ }^{1}$ Там же.
} 
Федерации «О прокуратуре Российской Федерации»), «назначение наказания в виде лишения свободы условно за преступление, совершенное умышленно» (пп «е1» П. 1 ст. 51 Федерального закона «О воинской обязанности и военной службе»), «назначение наказания в виде лишения свободы или лишения свободы условно» (пп «д» п.1 ст. 57.8 Федерального закона «О воинской обязанности и военной службе»), «назначение наказания в виде лишения воинского звания» (пп. «д» П.1 ст. 51, пп «г» п.1 ст. 57.8 Федерального закона «О воинской обязанности и военной службе»).

В статье 44 УК РФ перечислены виды наказания, анализ которых позволяет выделить наказания, которые исключают возможность исполнения должностных обязанностей по должности. К ним могут быть отнесены: лишение права занимать определенные должности или заниматься определенной деятельностью, ограничение свободы, принудительные работы, арест, лишение свободы на определенный срок, пожизненное лишение свободы, смертная казнь.

Таким образом, гражданские и муниципальные служащие могут замещать должности и проходить службу при осуждении к наказанию в виде штрафа, обязательных и исправительных работ.

Наиболее развернутый перечень наказаний подразумевается в пункте «д» ч.1 ст. 4 Федерального закона «О статусе члена Совета Федерации и статусе депутата Государственной Думы Федерального Собрания Российской Федерации», пп. «ж» п.1 ст. 19 Федерального закона «Об общих принципах организации законодательных (представительных) и исполнительных органов государственной власти субъектов Российской Федерации», п.6 ст. 36, п. 10 ст. 37, п. 10 ст. 40 Федерального закона «Об общих принципах организации местного самоуправления в Российской Федерации», п. 8 ч.1 ст. 14 Закона Российской Федерации «О статусе судей в Российской Федерации», п.2 ч.1 ст. 29 Федерального закона «О полиции», п.8 ст. 29 Федерального закона «Об основных гарантиях избирательных прав и права на участие в референдуме граждан Российской Федерации». 
В перечисленных законодательных актах в качестве основания для досрочного прекращения полномочий члена Совета Федерации, депутата Государственной Думы Федерального Собрания Российской Федерации, высшего должностного лица субъекта Российской Федерации, депутата, члена выборного органа местного самоуправления, выборного должностного лица местного самоуправления, главы местной администрации, главы муниципального образования, судьи, сотрудника полиции, члена избирательной комиссии с правом решающего голоса названо вступление в законную силу обвинительного приговора суда.

Конституционность прекращения депутатских полномочий в связи с вступлением в законную силу обвинительного приговора суда рассматривалась в Определении Конституционного Суда Российской Федерации от 12 мая 2003 г. № 168-О «Об отказе в принятии к рассмотрению жалобы гражданина Быкова А.П. на нарушение его конституционных прав положениями подпункта «в» пункта 3 статьи 35 Устава Красноярского края и подпункта «в» пункта 1 статьи 4 Закона Красноярского края «О статусе депутата Законодательного собрания Красноярского края» ${ }^{1}$.

По мнению Конституционного Суда Российской Федерации, досрочное прекращение депутатских полномочий не затрагивает право граждан избирать и быть избранными в органы публичной власти. Законоположения о досрочном прекращении депутатских полномочий не лишают условно осужденное лицо избирательных прав, не затрагивают его конституционный статус как гражданина и, следовательно, не противоречат статьям 32 и 55 Конституции Российской Федерации.

Для законодателя и правоприменителя в данной ситуации не имеет значения, какой обвинительный приговор был постановлен судом:

- связанный с назначением наказания осужденному;

- связанный с назначением наказания и освобождением от его отбывания;

\footnotetext{
${ }^{1}$ Вестник Конституционного Суда Российской Федерации. 2004. № 1.
} 
- без назначения наказания.

Если рассматривать обвинительный приговор с назначением наказания, то речь идет о любом обвинительном приговоре суда, вступившем в законную силу, в соответствии с которым лицу назначено наказание в виде штрафа, лишения права занимать определенные должности или заниматься определенной деятельностью, лишения специального, воинского или почетного звания, классного чина и государственных наград, обязательных работ, исправительных работ, ограничения по военной службе, ограничения свободы, принудительных работ, ареста, содержания в дисциплинарной воинской части, лишения свободы на определенный срок, пожизненного лишения свободы, смертной казни.

Согласно статье 311 УПК РФ в случае вынесения обвинительного приговора без назначения наказания; обвинительного приговора с назначением наказания и с освобождением от его отбывания; обвинительного приговора с назначением наказания, не связанного с лишением свободы, или наказания в виде лишения свободы условно подсудимый, находящийся под стражей, немедленно освобождается в зале суда.

В соответствии с ч.2 статьи 86 УК РФ лицо, освобожденное от наказания, считается несудимым.

Проблема связи судимости с фактом назначения наказания или с фактом его реального отбывания решена в п. 5 постановления Пленума Верховного Суда СССР от 18 марта 1970 г. № 4 (с изм. и доп., внесенными постановлениями Пленума Верховного Суда СССР от 21 сентября 1977 г. № 11; от 26 апреля 1984 г. № 7) «Об исчислении срока погашения судимости»: «При постановлении обвинительного приговора без назначения наказания, а также с освобождением осужденного от наказания в силу акта амнистии или в связи с истечением давностного срока виновный, как не отбывавший наказание, признается не имеющим судимости, независимо от продолжительности предварительного заключения». Таким образом, в 
судебной практике наличие судимости связывается с фактом отбывания (или неотбывания) наказания ${ }^{1}$.

Освобождение от отбывания наказания по приговору суда следует отличать от условно-досрочного освобождения от отбывания наказания.

Статьей 79 УК РФ устанавливается, что суд может освободить лицо, отбывшее указанную в законе часть назначенного по приговору наказания в виде лишения свободы, в том числе пожизненного, условно-досрочно, если признает, что для своего исправления данное лицо не нуждается в дальнейшем отбывании наказания. При этом суд призван, как вытекает из статей 19, 46 (часть 1), 50 (часть 3), 118 и 123 (часть 3) Конституции Российской Федерации в их взаимосвязи, обеспечить справедливую процедуру принятия решения об условно-досрочном освобождении осужденного от отбывания наказания, включая реальные судебные гарантии защиты его прав и законных интересов.

Конституционность статьи 79 УК РФ, устанавливающей основания применения условно-досрочного освобождения от отбывания наказания, и части третьей статьи 399 УПК РФ, регламентирующей порядок разрешения вопросов, связанных с исполнением приговора, оспаривалась в жалобе гражданина А.А. Груздева².

В Определении от 11 июля 2007 г. № 406-О «По жалобе гражданина Груздева А.А. на нарушение его конституционных прав статьей 79 УК РФ и частью 3 статьи 399 УПК РФ» Конституционный Суд Российской Федерации пришел к выводу о том, что положения статьи 79 УК РФ по своему конституционно-правовому смыслу не препятствуют применению условно-

1. ${ }^{1}$ Постановление Пленума Верховного Суда СССР от 18 марта 1970 г. № 4 «Об исчислении срока погашения судимости» // Сб. постановлений Пленума Верховного Суда СССР 1924-1977. Ч.2. М.: Известия, 1978; Постановление Пленума Верховного Суда СССР от 21 сентября 1977 г. № 11 «Об изменении и дополнении постановления Пленума Верховного Суда СССР от 18 марта 1970 г. № 4 «Об исчислении срока погашения судимости». [Текст не опубликован.]

${ }^{2}$ Определение Конституционного Суда Российской Федерации от 11 июля 2007 г. № 406-О «По жалобе гражданина Груздева А.А. на нарушение его конституционных прав статьей 79 УК РФ и частью 3 статьи 399 УПК РФ»// Вестник Конституционного Суда Российской Федерации. 2007. № 1. 
досрочного освобождения от наказания в отношении лиц, которым назначенное по приговору суда наказание в виде смертной казни было в порядке помилования заменено на лишение свободы. Порядок рассмотрения вопросов, связанных с исполнением приговора, определенный в ч.3 ст. 399 УПК РФ по своему конституционно-правовому смыслу предполагает предоставление осужденному возможности участвовать в рассмотрении судом вопроса об условно-досрочном освобождении, изложить свою позицию и представить в ее подтверждение необходимые доказательства. Удовлетворяя ходатайство осужденного об условно-досрочном освобождении либо отказывая в его удовлетворении, судья не просто соглашается с поступившими к нему заявлением осужденного и (или) материалами администрации учреждения, а принимает мотивированное решение, исходя из анализа всего комплекса вопросов, связанных с целесообразностью дальнейшего отбывания осужденным наказания и имеющих для осужденного не меньшее значение, чем вопросы, разрешаемые судом непосредственно в ходе рассмотрения уголовного дела по существу или при проверке законности и обоснованности приговора в кассационном и надзорном порядке ${ }^{1}$.

В диспозициях пункта «д» ч.1 ст. 4 Федерального закона «О статусе члена Совета Федерации и статусе депутата Государственной Думы Федерального Собрания Российской Федерации», пп. «ж» п.1 ст. 19 Федерального закона «Об общих принципах организации законодательных (представительных) и исполнительных органов государственной власти субъектов Российской Федерации», п.6 ст. 36, п. 10 ст. 37, п. 10 ст. 40 Федерального закона «Об общих принципах организации местного самоуправления в Российской Федерации», п. 8 ч.1 ст. 14 Закона Российской Федерации «О статусе судей в Российской Федерации», п.2 ч.1 ст. 29 Федерального закона «О полиции», закрепляющих основания для досрочного

\footnotetext{
${ }^{1}$ Там же.
} 
прекращения полномочий, внимание акцентируется на вступлении обвинительного приговора в законную силу.

Данное правовое положение в полной мере соответствует принципу презумпции невиновности, в соответствии с которым обвиняемый считается невиновным, пока его виновность в совершении преступления не будет доказана и установлена вступившим в законную силу приговором суда ${ }^{1}$.

Обвинительный приговор не может быть основан на предположениях и постановляется лишь при условии, что в ходе судебного разбирательства виновность подсудимого в совершении преступления подтверждена совокупностью исследованных судом доказательств ${ }^{2}$.

В случаях, если не установлено событие преступления, подсудимый не причастен к совершению преступления, в деянии подсудимого отсутствует состав преступления, в отношении подсудимого коллегией присяжных заседателей вынесен оправдательный вердикт, судом постановляется оправдательный приговор.

В соответствии со статьей 390 УПК РФ приговор суда первой инстанции вступает в законную силу по истечении срока его обжалования в апелляционном порядке, если он не был обжалован сторонами.

Приговор суда апелляционной инстанции вступает в законную силу с момента его провозглашения и может быть пересмотрен лишь в кассационном порядке, в порядке надзора, по новым или вновь открывшимся обстоятельствам. В случае подачи жалобы, представления в апелляционном порядке приговор вступает в законную силу в день вынесения решения судом апелляционной инстанции, если он не отменяется судом апелляционной инстанции с передачей дела на новое судебное разбирательство либо с возвращением уголовного дела прокурору.

Антикоррупционные стандарты и антикриминальные правовые механизмы могут быть реализованы в виде временного отстранения

1 Принцип презумпции невиновности закреплен в статье 49 Конституции Российской Федерации и статье 14 УПК РФ.

2 Часть 4 статьи 302 УПК РФ. 
должностного лица от замещения должности (исполнения должностных обязанностей), приостановления полномочий.

В пункте 1 статьи 32 Федерального закона «О государственной гражданской службе Российской Федерации» закреплена обязанность представителя нанимателя отстранить гражданского служащего от замещаемой должности гражданской службы, если данное лицо привлечено в качестве обвиняемого и судом вынесено постановление о его временном отстранении от должности.

При этом представитель нанимателя вправе отстранить от замещаемой должности гражданской службы (не допускать к исполнению должностных обязанностей) гражданского служащего на период: урегулирования конфликта интересов и проведения проверки сведений, представляемых государственным (муниципальным) служащим, соблюдения им ограничений и запретов.

В статье 42 Закона Российской Федерации «О прокуратуре Российской Федерации», части 2 статьи 29 Федерального закона «О Следственном комитете Российской Федерации» говорится об отстранении от должности на период расследования возбужденного в отношении прокурора (сотрудника Следственного комитета) уголовного дела. В статье 42 Федерального закона «О воинской обязанности и военной службе» предусмотрена возможность прохождения военной службы не на воинских должностях в случае нахождения в распоряжении командира (начальника) в связи с возбуждением в отношении военнослужащего уголовного дела - до вынесения решения по уголовному делу.

П.4. статьи 29.1 Федерального закона «Об общих принципах организации законодательных (представительных) и исполнительных органов государственной власти субъектов Российской Федерации» содержит норму о том, что Президент Российской Федерации в порядке, установленном уголовно-процессуальным законодательством, вправе по представлению Генерального прокурора Российской Федерации временно 
отстранить высшее должностное лицо субъекта Российской Федерации от исполнения обязанностей в случае предъявления указанному лицу обвинения в совершении преступления. Такое решение о временном отстранении высшего должностного лица субъекта Российской Федерации от исполнения обязанностей принимается в форме указа.

В соответствии со статьей 114 УПК РФ временное отстранение от должности относится к мерам процессуального принуждения.

При необходимости временного отстранения от должности подозреваемого или обвиняемого следователь с согласия руководителя следственного органа, а также дознаватель с согласия прокурора возбуждает перед судом по месту производства предварительного расследования соответствующее ходатайство. В течение 48 часов с момента поступления ходатайства судья выносит постановление о временном отстранении подозреваемого или обвиняемого от должности или об отказе в этом. Временное отстранение от должности отменяется на основании постановления дознавателя, следователя, когда в применении этой меры отпадает необходимость.

Приостановление судейских полномочий осуществляется по схожим основаниям. Но, в отличие от временного отстранения от должности, решение о приостановлении (возобновлении) полномочий принимает квалификационная коллегия судей.

Согласно статье 13 Закона Российской Федерации «О статусе судей в Российской Федерации» полномочия судьи и отставка судьи приостанавливаются решением квалификационной коллегии судей в случае возбуждения уголовного дела в отношении судьи либо привлечения его в качестве обвиняемого по другому уголовному делу.

Таким образом, анализ нормативных предписаний свидетельствует о наличии диспозитивных (возможных) и императивных (обязательных), общих и привилегированных оснований для временного отстранения 
должностного лица от замещения должности (исполнения должностных обязанностей), приостановления полномочий.

К диспозитивным основаниям отнесены: урегулирование конфликта интересов и проведение проверки сведений, представляемых государственным (муниципальным) служащим, соблюдения им ограничений и запретов.

Императивными основаниями являются: возбуждение уголовного дела в отношении лица, привлечение его в качестве обвиняемого по другому уголовному делу.

Общие основания касаются сходных обстоятельств и процедур отстранения от замещения должности (исполнения обязанностей), приостановления полномочий.

Привилегированные основания предусматривают особенную процедуру отстранения от исполнения обязанностей, приостановления полномочий отдельных должностных лиц.

Так, привилегированный порядок установлен в отношении процедуры временного отстранения высшего должностного лица субъекта Российской Федерации от исполнения обязанностей. В соответствии с ч.5 ст. 114 УПК РФ решение об отстранении высшего должностного лица субъекта Российской Федерации от исполнения обязанностей в случае предъявления обвинения в совершении тяжкого или особо тяжкого преступления принимается Президентом Российской Федерации, требует представления Генерального прокурора Российской Федерации и должно быть закреплено в форме указа Президента Российской Федерации. Привилегированные основания приостановления судейских полномочий требуют соответствующего решения квалификационной коллегии судей.

В ряде случаев законодатель определяет перечень сведений, имеющий непосредственное отношение к организации и функционированию антикриминальных правовых механизмов. 
Так, в статье 17 Федерального закона «О полиции» содержатся данные о гражданах, подлежащие включению в ведомственные специализированные банки данных и документы.

Внесению в банки данных подлежит информация:

- о лицах, подозреваемых или обвиняемых в совершении преступления;

- о лицах, осужденных за совершение преступления;

- о лицах, которые совершили преступление или общественно опасное деяние и в отношении которых судом применены принудительные меры медицинского характера;

- о лицах, в отношении которых вынесено постановление о прекращении уголовного преследования за истечением срока давности, в связи с примирением сторон, вследствие акта об амнистии, в связи с деятельным раскаянием;

- о несовершеннолетних, освобожденных от уголовной ответственности либо освобожденных судом от наказания с применением принудительных мер воспитательного воздействия; о несовершеннолетних, совершивших правонарушения и (или) антиобщественные действия, об их родителях или иных законных представителях, не исполняющих своих обязанностей по воспитанию, обучению и (или) содержанию детей и (или) отрицательно влияющих на их поведение либо жестоко обращающихся с ними;

- о лицах, в отношении которых до вступления приговора в законную силу был применен акт помилования или акт об амнистии, освобождающие от наказания;

- о лицах, в отношении которых совершено преступление;

- о лицах, совершивших административное правонарушение;

- о лицах, объявленных в розыск;

- о лицах, пропавших без вести;

- о лицах, состоящих на профилактическом учете;

- о лицах, в отношении которых заведены дела оперативного учета; 
- о лицах, прошедших государственную дактилоскопическую регистрацию.

Полиция обеспечивает защиту данной информации, содержащейся в банках данных, от неправомерного и случайного доступа, уничтожения, копирования, распространения и иных неправомерных действий

Самостоятельным фрагментом нормативного массива противодействия криминализации органов власти являются правовые акты, регламентирующие противодействие криминалитету в условиях выборных кампаний.

Правовой основой противодействия криминализации органов публичной власти в ходе выборов в Российской Федерации является Федеральный закон «Об основных гарантиях избирательных прав и права на участие в референдуме граждан Российской Федерации».

Требования к кандидатам на выборах в органы государственной власти и органы местного самоуправления устанавливаются Конституцией и Федеральными законами от 12 июня 2002 г. № 67-Ф3, от 10 января 2003 г. № 19-Ф3, от 18 мая 2005 г. № 51-Ф3.

Согласно части 3 статьи 32 Конституции Российской Федерации не обладают активным и пассивным избирательным правом граждане, признанные судом недееспособными или содержащиеся в местах лишения свободы по приговору суда.

В соответствии с пунктом 3.2 статьи 4 Федерального закона от 12 июня 2002 г. № 67-Ф3:

«Не имеют права быть избранными граждане Российской Федерации:

а) осужденные когда-либо к лишению свободы за совершение тяжких и (или) особо тяжких преступлений, за исключением случаев, когда в соответствии с новым уголовным законом эти деяния не признаются тяжкими или особо тяжкими преступлениями;

б) осужденные за совершение преступлений экстремистской направленности, предусмотренных Уголовным кодексом Российской 
Федерации, и имеющие на день голосования на выборах неснятую и непогашенную судимость за указанные преступления;

в) подвергнутые административному наказанию за совершение административных правонарушений, предусмотренных статьями 20.3 и 20.29 Кодекса Российской Федерации об административных правонарушениях, если голосование на выборах состоится до окончания срока, в течение которого лицо считается подвергнутым административному наказанию

г) в отношении которых вступившим в силу решением суда установлен факт нарушения ограничений, предусмотренных пунктом 1 статьи 56 настоящего Федерального закона, либо совершения действий, предусмотренных подпунктом «ж» пункта 7 и подпунктом «ж» пункта 8 статьи 76 настоящего Федерального закона, если указанные нарушения либо действия совершены до дня голосования на выборах в течение установленного законом срока полномочий органа государственной власти или органа местного самоуправления, в которые назначены выборы, либо должностного лица, для избрания которого назначены выборы».

Как отмечается в Постановлении Конституционного Суда Российской Федерации от 10 октября 2013 г. № 20-П «По делу о проверке конституционности подпункта «а» пункта 3.2 статьи 4 Федерального закона «об основных гарантиях избирательных прав и права на участие в референдуме граждан Российской Федерации», части первой статьи 10 и части 6 статьи 86 УК РФ в связи с жалобами граждан Г.Б.Егорова, А.Л.Казакова, И.Ю.Кравцова, А.В. Куприянова, А.С. Латыпова и В.Ю. Синькова», «ограничение пассивного избирательного права введено федеральным законодателем в качестве особого конституционно-правового дисквалифицирующего препятствия для занятия выборных публичных должностей, сопряженного с повышенными репутационными требованиями к носителям публичной (политической) власти, что обусловлено их прямым участием в принятии правовых актов (нормативных и индивидуальных) и 
ответственностью, с которой связано осуществление ими своих полномочий» ${ }^{1}$.

Особого внимания заслуживают конституционно-правовые ограничения, обусловленные особенностями правового статуса кандидатов.

Законодательство о выборах устанавливает две группы дополнительных ограничений пассивного избирательного права: ограничения, связанные с выдвижением кандидатов (списков кандидатов), и ограничения, связанные с регистрацичей кандидатов (списков кандидатов).

Ограничения, связанные с выдвижением кандидатов, установлены пунктами 4-7 статьи 32 Федерального закона от 12 июня 2002 г. № 67-Ф3. Гражданин Российской Федерации, замещавший должность Президента Российской Федерации и досрочно прекративший исполнение полномочий Президента Российской Федерации в случае отставки, стойкой неспособности по состоянию здоровья осуществлять принадлежащие ему полномочия или отрешения от должности, не может быть выдвинут кандидатом на выборах, назначенных в связи с указанными обстоятельствами.

Гражданин Российской Федерации, замещавший должность высшего должностного лица субъекта Российской Федерации (руководителя высшего исполнительного органа государственной власти субъекта Российской Федерации) и отрешенный от этой должности Президентом Российской Федерации, в течение двух лет, исчисляемых со дня вступления в силу указа Президента Российской Федерации об отрешении его от должности и до дня назначения выборов высшего должностного лица субъекта Российской Федерации (руководителя высшего исполнительного органа государственной власти субъекта Российской Федерации), не может быть выдвинут кандидатом на указанную должность ни в одном субъекте Российской Федерации.

\footnotetext{
${ }^{1}$ Рос. газ. 2013. 23 октября.
} 
Гражданин Российской Федерации, замещавший должность главы муниципального образования и ушедший с указанной должности в отставку по собственному желанию, в том числе в связи с избранием его депутатом либо на иную выборную должность, замещение которой несовместимо со статусом главы муниципального образования, либо отрешенный от должности главы муниципального образования высшим должностным лицом субъекта Российской Федерации (руководителем высшего исполнительного органа государственной власти субъекта Российской Федеращии), не может быть выдвинут кандидатом на выборах, назначенных в связи с указанными обстоятельствами. Комментируемые пункты устанавливают ограничения пассивного избирательного права для граждан, замещающих некоторые государственные и муниципальные должности, при проведении выборов на эти должности.

В пункте 7 статьи 4 Федерального закона от 12 июня 2002 г. № 67-Ф3 закреплено ограничение на регистрацию кандидатов: «При наличии в отношении гражданина Российской Федерации вступившего в силу решения суда о лишении его права занимать государственные и (или) муниципальные должности в течение определенного срока этот гражданин не может быть зарегистрирован в качестве кандидата, если голосование на выборах в органы государственной власти, органы местного самоуправления состоится до истечения указанного срока».

Кроме того, пунктом 6 статьи 3 Федерального закона от 10 января 2003 г. № 19-Ф3 установлено: «Гражданин Российской Федерации, в отношении которого вступил в силу приговор суда о лишении его права занимать государственные должности в течение определенного срока, если такое наказание предусмотрено федеральным законом, не может быть зарегистрирован в качестве кандидата на должность Президента Российской Федерации, если голосование на выборах Президента Российской Федерации состоится до истечения установленного судом срока». 
Аналогичным образом данное ограничение закреплено в пункте 5 статьи 5 Федерального закона от 18 мая 2005 г. № 51-Ф3: «Гражданин Российской Федерации, в отношении которого вступил в законную силу приговор суда о лишении его права занимать государственные должности в течение определенного срока, не может быть зарегистрирован в качестве кандидата на выборах депутатов Государственной Думы, если голосование на выборах состоится до истечения установленного судом срока».

В целях недопущения выдвижения и регистрации в качестве кандидатов на выборные должности лиц, находящихся в уголовном розыске, пункт 5 статьи 33 Федерального закона от 12 июня 2002 г. № 67-Ф3, пункт 10 статьи 34 Федерального закона от 10 января 2003 г. № 19-Ф3, предписывают кандидата лично подавать документы при его регистрации соответствующей избирательной комиссией.

В соответствии с подпунктами «а» пунктов 24 и 26 статьи статьи 38 Федерального закона от 12 июня 2002 г. № 67-Ф3 отсутствие у кандидата пассивного избирательного права является основанием для отказа в регистрации кандидата, исключения кандидата из заверенного списка кандидатов. При принятии решения о регистрации кандидата, списков кандидатов избирательная комиссия обязана удостовериться в наличии пассивного избирательного права у всех регистрируемых кандидатов ${ }^{1}$.

Пункт 2.1 статьи 33 Федерального закона от 12 июня 2002 г. № 67-Ф3 закрепляет обязанность кандидата указывать в заявлении о согласии баллотироваться сведения о наличии у него неснятой или непогашенной судимости. При этом требования об указании кандидатом сведений о бывших судимостях, в том числе за тяжкие и (или) особо тяжкие преступления, Федеральный закон не содержит.

Согласно пункту 4 статьи 61, пункту 7 статьи 63, пункту 9 статьи 37 Федерального закона от 12 июня 2002 г. № 67-Ф3; пункту 4 статьи 66, пункту

${ }^{1}$ Неронов И. К вопросу о проверке избирательной комиссией наличия у кандидатов пассивного избирательного права в свете изменения законодательства // О выборах. 2012 . № 5 . C 37 . 
6 статьи 67, подпункту 3 пункта 6 статьи 34 Федерального закона от 10 января 2003 г. № 19-Ф3; части 4 статьи 72, части 6 статьи 73, части 4 статьи 38 Федерального закона от 18 мая 2005 г. № 51-Ф3 сведения о неснятой и непогашенной судимости кандидата должны указываться в подписном листе, на информационных стендах и в избирательных бюллетенях. Подпункт «з» пункта 7 статьи 76 Федерального закона от 12 июня 2002 г. № 67-Ф3 отмечает, что регистрация кандидата может быть отменена судом в случае установления факта сокрытия кандидатом сведений о своей неснятой (непогашенной) судимости. Аналогичные санкции предусмотрены подпунктом 7 пункта 5 статьи 84 Федерального закона от 10 января 2003 г. № 19-Ф3 и подпунктом 4 части 9 статьи 91 Федерального закона от 18 мая 2005 г. № 51-Ф3. Данные правовые меры используются для предотвращения проникновения криминальных и экстремистских элементов в органы государственной власти и органы местного самоуправления в процессе выборов ${ }^{1}$.

Как уже отмечалось, пассивного избирательного права лишены граждане Российской Федерации, осужденные когда-либо к лишению свободы за совершение тяжких и (или) особо тяжких преступлений, за исключением случаев, когда в соответствии с новым уголовным законом эти преступления не признаются тяжкими или особо тяжкими преступлениями.

Из содержания данной нормы следует, что лицо, в отношении которого вступившим в законную силу приговором суда был установлен факт совершения тяжкого и (или) особо тяжкого преступления, за совершение которого ему назначено наказание в виде лишения свободы, не имеет права быть избранным. При этом наличие таких обстоятельств, как назначение наказания условно, освобождение от наказания, отсрочка отбывания

1 Франскевич М.П., Щедрин Н.В. Криминальное прошлое как основание ограничения пассивного избирательного права / Актуальные проблемы борьбы с преступностью в Сибирском регионе. Сб. материалов Международной научнопрактической конференции. Ч.1. Красноярск, 2005. С. 300-303; Дуксин П.А. Лишение пассивного избирательного права лиц, подвергнутых мерам юридической ответственности за совершение действий экстремистской направленности / Проблемы политической и правовой науки. Вып. 1. Саратов:Изд-во Сарат. ун-та, 2007. С. 190-194. 
наказания, амнистия, помилование, погашение или снятие судимости не влечет признания права данного гражданина быть избранным.

Постановлением Конституционного Суда Российской Федерации от 10 октября 2013 г. № 20-П «По делу о проверке конституционности подпункта «а» пункта 3.2 статьи 4 Федерального закона «об основных гарантиях избирательных прав и права на участие в референдуме граждан Российской Федерации», части первой статьи 10 и части 6 статьи 86 УК РФ в связи с жалобами граждан Г.Б.Егорова, А.Л.Казакова, И.Ю.Кравцова, А.В. Куприянова, А.С. Латыпова и В.Ю. Синькова» подпункт «а» пункта 3.2 статьи 4 комментируемого Федерального закона признан не соответствующим статьям 3 (части 2 и 3), 15 (часть 4), 17 (часть 3), 19 (части 1 и 2), 32 (части 1, 2 и 3) и 55 (части 2 и 3) Конституции Российской Федерации в той мере, в какой им установлено бессрочное и недифференцированное ограничение пассивного избирательного права в отношении граждан Российской Федерации, осужденных к лишению свободы за совершение тяжких и (или) особо тяжких преступлений ${ }^{1}$.

По мнению Конституционного Суда Российской Федерации, сроки вводимых федеральным законом ограничений пассивного избирательного права, по общему правилу, должны устанавливаться соответственно дифференциации сроков судимости, предусмотренной $У К \quad \Phi^{2}$. В исключительных случаях за отдельные тяжкие и особо тяжкие преступления, исходя из повышенной степени их общественной опасности, федеральным законом могут вводиться ограничения пассивного избирательного права и на

${ }^{1}$ Рос. газ. 2013. 23 октября.

${ }^{2}$ Согласно законопроекту, внесенному в Государственную Думу после принятия Конститушионным Сулом Российской Фелепашии Постановления от 10 октябия 2013 г. № 20-П. осvжденные когда-либо к лишению свободы за совершение тяжких престиплений. за исключением случаев. когда. в соответствии с новым уголовным законом. эти деяния не признаются тяжкими преступлениями. не смогут баллотиповаться в течение 10 лет со лня снятия или погашения судимости. а осvжденные когда-либо к лишению свободы за совершение особо тяжких преступлений - в течение 15 лет со дня снятия или погашения судимости. 
более продолжительные сроки с соблюдением конституционных критериев соразмерности и необходимости ${ }^{1}$.

Необходимо учитывать, что если впоследствии по делу в отношении гражданина вынесен оправдательный приговор и (или) у него возникло право на реабилитацию, то такое лицо является оправданным и (или) реабилитированным. В соответствии с частью 1 статьи 133 Уголовнопроцессуального кодекса Российской Федерации (УПК РФ) право на реабилитацию включает в себя, в том числе, восстановление в трудовых, пенсионных, жилищных и иных правах. Пунктом 4 части 2 статьи 133 УПК РФ установлено, что право на реабилитацию имеет осужденный в случае полной или частичной отмены вступившего в законную силу обвинительного приговора суда и прекращения уголовного дела по основаниям, предусмотренным пунктами 1 и 2 части 1 статьи 27 УПК РФ.

Согласно позиции Конституционного суда Российской Федерации, выраженной в Постановлении от 10 октября 2013 г. № 20-П, правовая демократия требует надежно защитить еe от злоупотреблений и криминализации публичной власти, легитимность которой во многом основывается на доверии общества, исходя из этого, запрет занимать выборные публичные должности для лиц, совершивших тяжкие и особо тяжкие преступления, преследует конституционно значимые цели.

Вместе с тем, Конституционный Суд Российской Федерации обязал федерального законодателя установить процессуальные гарантии, обеспечивающие возможность восстановления пассивного избирательного права граждан, судимость которых снята или погашена, в случае принятия нового уголовного закона, в соответствии с которым совершенное ими деяние более не признается тяжким или особо тяжким преступлением.

1 Постановление Конституционного Суда Российской Федерации от 10 октября 2013 г. № 20-П «По делу о проверке конституционности подпункта «а» пункта 3.2 статьи 4 Федерального закона «об основных гарантиях избирательных прав и права на участие в референдуме граждан Российской Федерации», части первой статьи 10 и части 6 статьи 86 УК РФ в связи с жалобами граждан Г.Б.Егорова, А.Л.Казакова, И.Ю.Кравцова, А.В. Куприянова, А.С. Латыпова и В.Ю. Синькова» // Рос. газ. 2013. 23 октября. 
Как уже отмечалось, головным субъектом противодействия криминализации органов публичной власти в условиях выборных кампаний являются избирательные комиссии.

Можно выделить ряд взаимосвязанных организационных форм антикриминальной деятельности избирательных комиссий в условиях избирательных кампаний:

- проверка достоверности представленных кандидатами сведений о неснятых (непогашенных) судимостях, судимостях за совершение тяжких и (или) особо тяжких преступлений;

- проверка достоверности представленных кандидатами сведений о доходах и имуществе, о вкладах в банках и ценных бумагах, сведений о счетах (вкладах), наличных денежных средствах и ценностях в иностранных банках, расположенных за пределами территории Российской Федерации;

- обращение в правоохранительные органы с запросами: о лицах, подозреваемых или обвиняемых в совершении преступления; о лицах, осужденных за совершение преступления; о лицах, в отношении которых вынесено постановление о прекращении уголовного преследования за истечением срока давности, в связи с примирением сторон, вследствие акта об амнистии, в связи с деятельным раскаянием; о лицах, в отношении которых до вступления приговора в законную силу был применен акт помилования или акт об амнистии, освобождающие от наказания; о лицах, совершивших административное правонарушение; о лицах, состоящих на профилактическом учете; о лицах, объявленных в розыск; о проверке связей кандидатов с представителями криминалитета, подконтрольными криминальным структурам организациями и кредитными учреждениями;

- исключение кандидата (группы кандидатов) из заверенных списков;

- отказ в регистрации кандидата (списков кандидатов);

- аннулирование регистрации кандидата (списка кандидатов) вышестоящей комиссией; 
- обращение в суд с представлением об отмене регистрации кандидата (списка кандидатов);

- контроль за источниками поступления, правильным учетом и использованием денежных средств избирательных фондов;

- проверка финансовых отчетов кандидатов;

- проведение антикоррупционной экспертизы нормативных актов избирательных комиссий;

- информирование правоохранительных органов и спецслужб для проверки сигналов, пресечения противоправной агитационной деятельности, производства по делам об административных правонарушениях или предварительного расследования;

- производство по делам об административных правонарушениях в сфере выборов, отнесенных к компетенции членов избирательных комиссий с правом решающего голоса.

Анализ результатов проверки сведений о наличии фактов осуждения за совершение тяжких и (или) особо тяжких преступлений кандидатов в депутаты законодательных (представительных) органов государственной власти субъектов Российской Федерации и представительных органов административных центров субъектов Российской Федерации по выборам 14 октября 2012 года показал, что среди членов избирательных комиссий и работников их аппаратов отсутствует единое понимание требований действующей редакции подпункта «а» пункта 3.2 статьи 4 Федерального закона. В комиссиях возникают также сложности с определением категорий (тяжести) преступлений с учетом осуждения лиц в период действия разных редакций уголовного закона. В значительной степени это связано с отсутствием практики правоприменения в указанных обстоятельствах ${ }^{1}$.

1 Справка Аппарата ЦИК России «О практике применения новой редакции подпункта «а» пункта 3.2 статьи 4 Федерального закона «Об основных гарантиях избирательных прав и права на участие в референдуме граждан Российской Федерации». C.2. 
Аппаратом ЦИК России было установлено, что по состоянию на 28 сентября 2012 г. в числе зарегистрированных кандидатов в депутаты законодательных (представительных) органов государственной власти субъектов Российской Федерации и представительных органов административных центров субъектов Российской Федерации оставалось около 20 человек, которые, исходя из данных ГИАЦ МВД России, по закону не имели права быть избранными ${ }^{1}$.

В результате принятых ЦИК России во взаимодействии с ГИАЦ МВД России мер, из числа зарегистрированных кандидатов в депутаты законодательных (представительных) органов государственной власти субъектов Российской Федерации и представительных органов административных центров субъектов Российской Федерации по выборам 14 октября 2012 года исключены (по личному заявлению, решениями избирательных комиссий либо судебными решениями) 17 лиц, в отношении которых имелись сведения об осуждении к лишению свободы за совершение тяжких и (или) особо тяжких преступлений.

В связи с уточнением степени тяжести преступлений с учетом периода действия разных редакций уголовного закона допущены к участию в выборах на законных основаниях 13 кандидатов, пассивное избирательное право которых подтверждено 2 .

Вместе с тем, один кандидат в депутаты Государственного Совета Удмуртской Республики пятого созыва, в отношении которого подтверждены сведения об осуждении к лишению свободы за тяжкое преступление, участвовал в выборах 14 октября 2012 года и был избран³. Информация о

${ }^{1}$ Всего ГИАЦ МИД России были представлены сведения о фактах осуждения за тяжкие и (или) особо тяжкие преступления в отношении 53 выдвинутых и зарегистрированных кандидатов по данным уровням выборов. Ранее, в результате персональных разъяснений позиций федерального законодательства несколько кандидатов утратили статус зарегистрированных.

2 В настоящее время совершенные данными лицами преступления не квалифицируются как тяжкие или особо тяжкие.

3 Справка Аппарата ЦИК России «О практике применения новой редакции подпункта «а» пункта 3.2 статьи 4 Федерального закона «Об основных гарантиях 
наличии у кандидата указанных выше ограничений была доведена руководству ЦИК Удмуртской Республики 27 сентября 2012 года, однако срок на подачу в суд заявления об отмене регистрации территориальной избирательной комиссией был пропущен и впоследствии судом не восстановлен.

Помимо участия избирательных комиссий и правоохранительных органов в реализации антикриминальной политики противодействие дальнейшему проникновению преступных организаций (сообществ) в органы власти и их сращиванию с другими институтами политической системы российского общества требует незамедлительной и планомерной работы как государственных органов, так и структур гражданского общества в рамках следующих основных направлений:

тесная координация деятельности правоохранительных органов, СМИ, политических партий и общественных организаций по недопущению партийной коррупции и избрания (назначения) представителей криминалитета в органы государственной власти и местного самоуправления;

подрыв экономической базы преступных сообществ, вытеснение представителей криминалитета из легального бизнеса;

формирование негативного отношения населения к деятельности преступных сообществ, криминальным лидерам и популяризация антикриминальных мер;

совершенствование законодательства о выборах, государственной и муниципальной службе путем установления правовых ограничений на избрание (назначение на должности) в органы государственной власти и местного самоуправления лиц, находящихся под следствием, в розыске, а также граждан, в отношении которых уголовное преследование было C.3-4. 
прекращено за истечением срока давности, в связи с примирением сторон, вследствие акта об амнистии, в связи с деятельным раскаянием;

усиление требований к замещению государственных должностей Российской Федерации, государственных должностей субъектов Российской Федерации, должностей гражданской, военной, правоохранительной и муниципальной службы;

введение обязательных антикриминальных проверок всех кандидатов, поступающих на гражданскую, военную, правоохранительную и муниципальную службу;

расширение перечня должностных лиц, представляющих сведения о своих доходах, расходах, об имуществе и обязательствах имущественного характера, а также о доходах, расходах, имуществе и обязательствах имущественного характера своих супруги (супруга) и несовершеннолетних детей; уточнение требований о расходах указанных должностных лиц; введение антикоррупционных ограничений в отношении запрета иметь зарегистрированное за пределами Российской Федерации право собственности на имущество;

регулярное проведение антикоррупционных (антикриминальных) расследований;

совершенствование методики антикоррупционной экспертизы нормативных правовых актов;

ликвидация (ограничение числа и содержания) иммунитетов выборных должностных лиц и депутатской неприкосновенности;

расширение перечня оснований исключения кандидатов из заверенного списка, а также отказа кандидату в регистрации и отмены регистрации кандидата судом в связи с представлением подложных документов или заведомо ложных сведений.

Формирование и последовательное осуществление перечисленных направлений противодействия криминализации органов публичной власти предполагает тщательным образом скоординированную деятельность всех 
правоохранительных органов и органов управления. Такой уровень работы должен в обязательном порядке замыкаться на Президента и Председателя Правительства Российской Федерации.

Наиболее важным направлением противодействия криминализации органов публичной власти представляется подрыв экономической базы преступных сообществ и вытеснение представителей криминалитета из легального бизнеса.

В целях противодействия легализации криминальных доходов уполномоченными органами в соответствии с Федеральным законом «О противодействии легализации (отмыванию) доходов, полученных преступным путем, и финансированию терроризма» уполномоченными органами могут осуществляться следующие меры:

- внутренний контроль (выявление операций, подлежащих обязательному контролю, и иных операций с денежными средствами или иным имуществом, связанных с легализацией преступных доходов);

- обязательный контроль (контроль за операциями с денежными средствами или иным имуществом, а также проверка соответствующей информации);

- приостановление операции;

- отказ в выполнении распоряжения клиента о совершении операции;

- отказ от заключения договора банковского счета (вклада) (при попытках открыть вклад на анонимного владельца; открыть вклад без личного присутствия лица, открывающего вклад; при непредставлении необходимых документов для идентификации клиента);

- блокирование (замораживание) безналичных денежных средств или бездокументарных ценных бумаг;

- блокирование (замораживание) имущества клиента;

- запрет на информирование клиентов и иных лиц о принимаемых мерах противодействия легализации (отмыванию) доходов, полученных преступным путем. 
Согласно ч.2 статьи 6 Федерального закона «О противодействии легализации (отмыванию) доходов, полученных преступным путем, и финансированию терроризма» операция с денежными средствами или иным имуществом подлежит обязательному контролю в случае, если хотя бы одной из сторон является организация или физическое лицо, в отношении которых имеются сведения об их причастности к экстремистской деятельности или терроризму, либо юридическое лицо, прямо или косвенно находящееся в собственности или под контролем таких организации или лица, либо физическое или юридическое лицо, действующее от имени или по указанию таких организации или лица.

Основаниями для включения организации или физического лица в перечень организаций и физических лиц, в отношении которых имеются сведения об их причастности к экстремистской деятельности или терроризму, являются:

1) вступившее в законную силу решение суда Российской Федерации о ликвидации или запрете деятельности организации в связи с eе причастностью к экстремистской деятельности или терроризму;

2) вступивший в законную силу приговор суда Российской Федерации о признании лица виновным в совершении хотя бы одного из преступлений, предусмотренных статьями 205, 205.1, 205.2, 206, 208, 211, 220, 221, 277, 278, $279,280,282,282.1,282.2$ и 360 УК РФ;

3) решение Генерального прокурора Российской Федерации, подчиненного ему прокурора или федерального органа исполнительной власти в области государственной регистрации (его соответствующего территориального органа) о приостановлении деятельности организации в связи с их обращением в суд с заявлением о привлечении организации к ответственности за экстремистскую деятельность;

4) процессуальное решение о признании лица подозреваемым в совершении хотя бы одного из преступлений, предусмотренных статьями 
$205,205.1,205.2,206,208,211,220,221,277,278,279,280,282,282.1,282.2$ и 360 УК РФ;

5) постановление следователя о привлечении лица в качестве обвиняемого в совершении хотя бы одного из преступлений, предусмотренных статьями 205, 205.1, 205.2, 206, 208, 211, 220, 221, 277, 278, $279,280,282,282.1,282.2$ и 360 УК РФ;

6) составляемые международными организациями, осуществляющими борьбу с терроризмом, или уполномоченными ими органами и признанные Российской Федерацией перечни организаций и физических лиц, связанных с террористическими организациями или террористами;

7) признаваемые в Российской Федерации в соответствии с международными договорами Российской Федерации и федеральными законами приговоры или решения судов и решения иных компетентных органов иностранных государств в отношении организаций или физических лиц, осуществляющих террористическую деятельность.

Часть 2.2 статьи 6 Федерального закона «О противодействии легализации (отмыванию) доходов, полученных преступным путем, и финансированию терроризма» содержит следующие основания для исключения организации или физического лица из перечня организаций и физических лиц, в отношении которых имеются сведения об их причастности к экстремистской деятельности или терроризму:

1) отмена вступившего в законную силу решения суда Российской Федерации о ликвидации или запрете деятельности организации в связи с еe причастностью к экстремистской деятельности или терроризму и прекращение производства по делу;

2) отмена вступившего в законную силу приговора суда Российской Федерации о признании лица виновным в совершении хотя бы одного из преступлений, предусмотренных статьями 205, 205.1, 205.2, 206, 208, 211, 220, 221, 277, 278, 279, 280, 282, 282.1, 282.2 и 360 УК РФ, и прекращение 
производства по уголовному делу в отношении данного лица по реабилитирующим основаниям;

3) отмена решения Генерального прокурора Российской Федерации, подчиненного ему прокурора или федерального органа исполнительной власти в области государственной регистрации (его соответствующего территориального органа) о приостановлении деятельности организации в связи с привлечением к ответственности за экстремистскую деятельность;

4) прекращение уголовного дела или уголовного преследования в отношении лица, подозреваемого или обвиняемого в совершении хотя бы одного из преступлений, предусмотренных статьями 205, 205.1, 205.2, 206, 208, 211, 220, 221, 277, 278, 279, 280, 282, 282.1, 282.2 и 360 УК РФ;

5) исключение организации или физического лица из составляемых международными организациями, осуществляющими борьбу с терроризмом, или уполномоченными ими органами и признанных Российской Федерацией перечней организаций и физических лиц, связанных с террористическими организациями или террористами;

6) отмена признаваемых в Российской Федерации в соответствии с международными договорами Российской Федерации и федеральными законами приговоров или решений судов и решений иных компетентных органов иностранных государств в отношении организаций или физических лиц, осуществляющих террористическую деятельность;

7) наличие документально подтвержденных данных о смерти лица, включенного в перечень организаций и физических лиц, в отношении которых имеются сведения об их причастности к экстремистской деятельности или терроризму;

8) наличие документально подтвержденных данных о погашении или снятии судимости с лица, осужденного за совершение хотя бы одного из преступлений, предусмотренных статьями 205, 205.1, 205.2, 206, 208, 211 , 220, 221, 277, 278, 279, 280, 282, 282.1, 282.2 и 360 УК РФ. 
В пункте 2 статьи 7 комментируемого Федерального закона перечислены основания для документального фиксирования сведений об операциях с денежными средствами или иным имуществом, клиентах и иных лицах. В соответствии с правилами внутреннего контроля к числу таких оснований относятся:

запутанный или необычный характер сделки, не имеющей очевидного экономического смысла или очевидной законной цели;

несоответствие сделки целям деятельности организации, установленным учредительными документами этой организации;

выявление неоднократного совершения операций или сделок, характер которых дает основание полагать, что целью их осуществления является уклонение от процедур обязательного контроля;

совершение операции, сделки клиентом, в отношении которого уполномоченным органом в организацию направлен либо ранее направлялся запрос;

отказ клиента от совершения разовой операции, в отношении которой у работников организации возникают подозрения, что указанная операция осуществляется в целях легализации (отмывания) доходов, полученных преступным путем, или финансирования терроризма;

иные обстоятельства, дающие основания полагать, что сделки осуществляются в целях легализации (отмывания) доходов, полученных преступным путем, или финансирования терроризма.

Статья 7.4 Федерального закона «О противодействии легализации (отмыванию) доходов, полученных преступным путем, и финансированию терроризма» устанавливает специальный правовой режим дополнительных мер противодействия финансированию терроризма - блокирования (замораживания) денежных средств или иного имущества организаций и физических лиц. При наличии достаточных оснований подозревать причастность организации или физического лица к террористической деятельности (в том числе к финансированию терроризма), если при этом 
отсутствуют основания для включения таких организации или физического лица в перечень организаций и физических лиц, в отношении которых имеются сведения об их причастности к экстремистской деятельности или терроризму, межведомственным координационным органом, осуществляющим функции по противодействию финансированию терроризма, может быть принято решение о замораживании (блокировании) денежных средств или иного имущества указанных организации или физического лица.

На наш взгляд, Федеральный закон «О противодействии легализации (отмыванию) доходов, полученных преступным путем, и финансированию терроризма» необоснованно ограничивает возможность блокирования (замораживания) преступно нажитого имущества причастностью к террористической и иной экстремистской деятельности.

Правовой режим блокирования (замораживания) денежных средств или иного имущества организаций и физических лиц должен быть распространен на любые доходы, полученные преступным путем, а не только на имущество организаций и граждан, подозреваемых в причастности к экстремистской деятельности или терроризму.

Одной из эффективных мер противодействия организованной преступной деятельности и коррупции выступает конфискация имущества.

В связи с либерализацией уголовного законодательства в Российской Федерации конфискация как вид наказания, связанный с применением экономических санкций к преступникам, была изъята из Уголовного кодекса. Федеральным законом от 27 июля 2006 г. № 153-Ф3 конфискация восстановлена, но отнесена законодателем к иным мерам уголовно-правового характера.

Как представляется, существующая нормативная форма института конфискации требует серьёзной модернизации в силу ряда обстоятельств:

- она позволяет преступникам сохранить большую часть имущества, добытого преступным путем; 
- она не подрывает материальную базу совершения преступлений;

- она не устраняет имущественный вред, причиненный преступлением.

По мнению специалистов, в УК РФ установлен ограничительный перечень конфискуемого имущества, полученного в результате совершения преступлений ${ }^{1}$. Возникают вопросы: на каких основаниях выбран тот круг преступлений, за совершение которых применение конфискации возможно? Почему в него не вошли другие деяния, результатом совершения которых становится имущественная выгода? В особенности это касается корыстных преступлений против собственности: то, что их не оказалось в перечне, вызывает, по крайней мере, недоумение ${ }^{2}$.

Статьей 104.1 УК РФ предусмотрено изъятие имущества, используемого или предназначенного для финансирования преступной деятельности, а именно: терроризма, создания и деятельности организованной группы, незаконного вооруженного формирования, преступного сообщества (преступной организации). Это обусловлено положениями международных конвенций о противодействии преступности, ратифицированных Россией.

Эксперты справедливо задаются вопросом, почему среди данной группы преступлений не названы посягательства, тесно связанные с терроризмом, а также легализацией преступно нажитого имущества? Такие, как ст. 211 «Угон судна воздушного или водного транспорта либо железнодорожного подвижного состава», ст. 221 «Хищение либо вымогательство ядерных материалов или радиоактивных веществ», ст. 226 «Хищение либо вымогательство оружия, боеприпасов, взрывчатых веществ и взрывных устройств», ст. 174 «Легализация (отмывание) денежных средств или иного имущества, приобретенных другими лицами преступным путем»,

1 Лужбин А.В., Волков К.А. Конфискация имущества - «новая» мера уголовноправового характера и новые проблемы // Рос. юстиция. 2006, № 9. С. 34; Зацепин М.Н. Конфискация имущества как мера противодействия коррупции // Рос. юрид. журнал. 2012. № 5.

2 Зацепин М.Н. Конфискация имущества как мера противодействия коррупции // Рос. юрид. журнал. 2012. № 5. 
ст. 174.1 «Легализация (отмывание) денежных средств или иного имущества, приобретенных лицом в результате совершения им преступления» ${ }^{1}$. Между тем во многих странах конфискация распространяется на имущество, используемое или предназначенное для финансирования любых, а не только указанных в российском Уголовном законе преступлений.

С целью действительного подрыва экономической базы преступных сообществ, а не имитации борьбы с преступностью, конфискация имущества должна быть возвращена в разряд видов уголовного наказания. При этом перечень преступлений, за совершение которых возможно применение конфискации, нуждается в дополнении составами, результатом совершения которых становится получение имущественной выгоды.

Важнейшим направлением противодействия криминализации органов публичной власти в Российской Федерации выступает формирование негативного отношения населения к деятельности преступных сообществ, криминальным лидерам и популяризация антикриминальных мер.

Необходима системная пропаганда правовых знаний, информирование широких слоев населения о юридических последствиях участия в преступной деятельности и оказания пособнической помощи криминальным структурам.

В современных условиях востребована активная разъяснительная и профилактическая работа в молодежной среде, повышение общеобразовательного и культурного уровня подростков, особенно из «неблагополучных» семей.

При муниципальных образовательных и культурно-просветительских учреждениях целесообразно создание общественных центров профилактики преступности. В состав этих центров помимо должностных лиц муниципалитетов и региональных органов власти должны входить деятели науки, образования, культуры, авторитетные представители религиозных объединений и общественных организаций, руководители землячеств и

1 Лужбин А.В., Волков К.А. Конфискация имущества - «новая» мера уголовноправового характера и новые проблемы // Рос. юстиция. 2006, № 9. 
национально-культурных автономий. Одной из задач таких центров должно стать глубокое изучение современной криминальной идеологии и уголовной субкультуры, а также противодействие им.

В целях подрыва социальной базы криминалитета требуется дискредитация положительного имиджа «героев-бандитов» в литературе, СМИ, Интернете, «деромантизация» криминальных лидеров, популяризация в СМИ и сетевых изданиях успешных операций правоохранительных органов и спецслужб по разработке криминальных структур и коррумпированных чиновников органов власти и управления.

Самостоятельной задачей является идеологическое обеспечение уголовного преследования организаторов, активных участников преступных сообществ и их пособников.

Следует учитывать, что информационно-пропагандистская работа по противодействию криминализации органов публичной власти в Российской Федерации должна носить не абстрактный теоретический характер, а быть практически ориентированной на целевые аудитории.

Серьезную помощь в реализации антикриминальной политики могут оказать органы прокуратуры и Следственного комитета. Ключевое положение прокуратуры обусловлено координирующей ролью в деятельности правоохранительных органов по борьбе с преступностью, спецификой сферы правового регулирования прокурорского надзора за исполнением законодательства о выборах, а также установленными законодательством полномочиями прокурора по осуществлению надзорной деятельности.

Органы Следственного комитета сообщают избирательным комиссиям (соответственно уровню проводимых выборов) о даче согласия на привлечение к уголовной ответственности или об избрании в качестве меры пресечения заключения под стражу зарегистрированных кандидатов на выборную должность. 
Решение о возбуждении уголовного дела либо о привлечении в качестве обвиняемого в отношении кандидата в Президенты Российской Федерации, зарегистрированного кандидата в депутаты Государственной Думы Федерального Собрания Российской Федерации принимается Председателем Следственного комитета Российской Федерации, в отношении зарегистрированного кандидата в депутаты законодательного органа государственной власти субъекта Российской Федерации руководителем следственного органа Следственного комитета Российской Федерации по субъекту Российской Федерации.

Ходатайство перед судом об избрании в качестве меры пресечения заключения под стражу может быть возбуждено следователем или дознавателем в отношении зарегистрированного кандидата в депутаты Государственной Думы Федерального Собрания Российской Федерации, кандидата в Президенты Российской Федерации с согласия Председателя Следственного комитета Российской Федерации, а в отношении зарегистрированного кандидата в депутаты законодательного органа государственной власти субъекта Российской Федерации - с согласия руководителя следственного органа Следственного комитета Российской Федерации по субъекту Российской Федерации.

Анализ УПК РФ свидетельствует о привилегированном процессуальном статусе кандидата в Президенты Российской Федерации. Изъятия из общего порядка уголовного судопроизводства на кандидата в Президенты Российской Федерации распространяются с момента его выдвижения в качестве кандидата, а на кандидатов в депутаты Государственной Думы Федерального Собрания Российской Федерации, в депутаты законодательного органа государственной власти субъекта Российской Федерации - с момента регистрации в качестве кандидата.

Органы Следственного комитета участвуют в осуществлении процессуальных и следственных действий в отношении депутатов, судей и членов избирательных комиссий различного уровня. 
Возбуждение уголовного дела и привлечение в качестве обвиняемого члена Совета Федерации и депутата Государственной Думы Федерального Собрания Российской Федерации осуществляется с санкции Председателя Следственного комитета Российской Федерации с согласия соответственно Совета Федерации и Государственной Думы, полученного на основании представления Генерального прокурора Российской Федерации.

Решение о возбуждении уголовных дел в отношении депутатов законодательного органа государственной власти субъекта Российской Федерации, депутатов, членов выборных органов местного самоуправления, выборных должностных лиц органа местного самоуправления и привлечение данной категории граждан в качестве обвиняемых осуществляются с санкции руководителя следственного органа Следственного комитета Российской Федерации по субъекту Российской Федерации.

10 апреля 2001 г. Законодательное Собрание Красноярского края на основании статей 13 и 14 действовавшей редакции Федерального закона «Об общих принципах организации законодательных (представительных) и исполнительных органов государственной власти субъектов Российской Федерации» отказалось дать согласие на передачу в суд уголовного дела в отношении депутата А.П. Быкова.

В связи с этим вопрос о неприкосновенности депутатов законодательных (представительных) органов государственной власти субъектов Российской Федерации и обусловленном статусом депутата особом порядке привлечения к уголовной или административной ответственности стал предметом рассмотрения Конституционного Суда Российской Федерации ${ }^{1}$.

${ }^{1}$ См. также Постановления Конституционного Суда Российской Федерации от 30 ноября 1995 года по делу о проверке конституционности статей 23 и 24 Временного положения об обеспечении деятельности депутатов Калининградской областной Думы, от 20 февраля 1996 года по делу о проверке конституционности положений статей 18, 19 и 20 Федерального закона «О статусе депутата Совета Федерации и статусе депутата Государственной Думы Федерального Собрания Российской Федерации», от 10 декабря 1997 года по делу о проверке конституционности ряда положений Устава (Основного закона) Тамбовской области, а также Определения по запросам о проверке 
В Постановлении от 12 апреля 2002 года № 9-П «По делу о проверке конституционности положений статей 13 и 14 Федерального закона «Об общих принципах организации законодательных (представительных) и исполнительных органов государственной власти субъектов Российской Федерации» в связи с жалобой гражданина А.П. Быкова, а также запросами Верховного Суда Российской Федерации и Законодательного Собрания Красноярского края» Конституционный Суд Российской Федерации пришел к выводу, что законодатель субъекта Российской Федерации, регулируя в пределах своей компетенции вопросы статуса депутата, не может предусматривать освобождение его от уголовной и административной ответственности, установленной федеральным законом, поскольку это было бы вторжением в сферу ведения и полномочий Российской Федерации ${ }^{1}$. Вопрос о неприкосновенности депутатов в той мере, в какой он затрагивает сферу действия уголовного и уголовно-процессуального законодательства и основные принципы административной ответственности, относится к ведению Российской Федерации. Поэтому для депутатов законодательных (представительных) органов субъектов Российской Федерации особые условия привлечения к уголовной и административной ответственности законами субъектов Российской Федерации устанавливаться не могут.

По мнению Конституционного Суда Российской Федерации, институт парламентской неприкосновенности призван оградить депутата от неправомерного вмешательства в его деятельность по осуществлению мандата, от попыток оказать на него давление, в том числе со стороны органов исполнительной власти путем привлечения или угрозы привлечения к уголовной или административной ответственности. Вместе с тем

конституционности статей 37 и 39 Закона СССР «О статусе народных депутатов в СССР» (от 8 января 1998 года N 3-O), статей 19 и 20 Закона Воронежской области «О статусе депутата Воронежской областной Думы» (от 4 июня 1998 года N 96-O), ряда положений Закона Иркутской области «О статусе депутата Законодательного собрания Иркутской области» (от 5 ноября 1998 года N 147-O).

${ }^{1}$ Рос. газ. 2002. 25 апреля. 


\section{неприкосновенность не может рассматриваться как личная привилегия} депутата, освобождающая его от ответственности за совершенные уголовные и административные правонарушения. Конкретный объем неприкосновенности, обеспечивающий недопустимость преследования депутата в связи с его депутатской деятельностью и в целях оказания влияния на нее, определяется федеральным законом.

Исходя из предназначения института парламентской неприкосновенности, участие законодательного (представительного) органа государственной власти субъекта Российской Федерации в процедуре лишения депутата неприкосновенности возможно только в отношении действий, совершаемых им при осуществлении депутатских полномочий. Предоставление же парламенту, не являющемуся ни органом уголовного преследования, ни судебным органом, права освобождать от законного привлечения к уголовной или административной ответственности несовместимо с целями института парламентской неприкосновенности. Это тем более недопустимо, когда дознание, предварительное следствие или производство по административному правонарушению уже завершено и, следовательно, речь, по существу, идет о необходимости получения согласия на передачу дела в суд, т.е. фактически о том, позволить ли суду рассматривать дело ${ }^{1}$.

C учетом сформулированной позиции Конституционный Суд Российской Федерации признал положения пунктов 1, 2 и 3 статьи 13 и пунктов 1, 2 и 4 статьи 14 Федерального закона «Об общих принципах организации законодательных (представительных) и исполнительных органов государственной власти субъектов Российской Федерации» - в той мере, в какой ими устанавливался запрет на привлечение депутата к

1 Постановление Конституционного Суда Российской Федерации от 12 апреля 2002 года № 9-П «По делу о проверке конституционности положений статей 13 и 14 Федерального закона «Об общих принципах организации законодательных (представительных) и исполнительных органов государственной власти субъектов Российской Федерации» в связи с жалобой гражданина А.П. Быкова, а также запросами Верховного Суда Российской Федерации и Законодательного Собрания Красноярского края» // Рос. газ. 2002. 25 апреля. 
уголовной и к административной ответственности, налагаемой в судебном порядке, и на осуществление обусловленных этим мер уголовнопроцессуального и административно-процессуального характера без согласия законодательного (представительного) органа государственной власти субъекта Российской Федерации, - не соответствующими Конституции Российской Федерации, ее статьям 10, 19 (часть 1), 46 (часть 1), 118 и 126.

Положение пункта 4 статьи 13 Федерального закона «Об общих принципах организации законодательных $\quad$ (представительных) и исполнительных органов государственной власти субъектов Российской Федерации», согласно которому в случае возбуждения дела, предусматривающего уголовную или административную ответственность, налагаемую в судебном порядке, в отношении действий депутата, не связанных с осуществлением им своих полномочий, по завершении дознания, предварительного следствия или производства по административным правонарушениям такое дело не может быть передано в суд без согласия законодательного (представительного) органа государственной власти субъекта Российской Федерации, а также положение пункта 3 статьи 14 данного Федерального закона, на основании которого для получения такого согласия прокурор субъекта Российской Федерации вносит представление в законодательный (представительный) орган государственной власти субъекта Российской Федерации, также были признаны не соответствующими Конституции Российской Федерации, ее статьям 10, 19 (часть 1), 46 (часть 1), 118 и 126.

Возбуждение уголовного дела в отношении судьи Конституционного Суда Российской Федерации и привлечение указанного лица в качестве обвиняемого осуществляется решением Председателя Следственного комитета Российской Федерации с согласия Конституционного Суда Российской Федерации; - в отношении судьи Верховного Суда Российской Федерации, Высшего Арбитражного Суда Российской Федерации, верховного суда республики, краевого или областного суда, суда города 
федерального значения, суда автономной области и суда автономного округа, федерального арбитражного суда, военного суда - решением Председателя Следственного комитета Российской Федерации с согласия Высшей квалификационной коллегии судей Российской Федерации; - в отношении иных судей - решением Председателя Следственного комитета Российской Федерации с согласия соответствующей квалификационной коллегии судей.

Согласно пункту 7 статьи 16 Закона Российской Федерации от 26 июня 1992 года № 3132-I «О статусе судей в Российской Федерации» осуществление в отношении судьи оперативно-розыскных мероприятий, а также следственных действий (если в отношении судьи не возбуждено уголовное дело либо он не привлечен в качестве обвиняемого по уголовному делу), связанных с ограничением его гражданских прав либо с нарушением его неприкосновенности, допускается не иначе как на основании решения, принимаемого соответствующей судебной коллегией.

Федеральный закон от 12 августа 1995 года № 144-Ф3 «Об оперативнорозыскной деятельности» предусматривает в части первой статьи 9, что рассмотрение материалов об ограничении конституционных прав граждан на тайну переписки, телефонных переговоров, почтовых, телеграфных и иных сообщений, передаваемых по сетям электрической и почтовой связи, на неприкосновенность жилища при проведении оперативно-розыскных мероприятий осуществляется судом, как правило, по месту проведения таких мероприятий или по месту нахождения органа, ходатайствующего об их проведении; указанные материалы рассматриваются уполномоченным на то судьей единолично и незамедлительно; судья не вправе отказать в рассмотрении таких материалов в случае их представления.

Территориальная подсудность вопроса о даче разрешения на проведение в отношении лица, занимающего должность судьи районного суда, оперативно-розыскных мероприятий, связанных с ограничением его гражданских прав либо с нарушением его неприкосновенности рассматривалась в Постановлении Конституционного Суда Российской 
Федерации от 9 июня 2011 г. № $12-П$ «По делу о проверке конституционности положений пункта 7 статьи 16 Закона Российской Федерации «О статусе судей в Российской Федерации» и части 1 статьи 9 Федерального закона «Об оперативно-розыскной деятельности» в связи с жалобой гражданина И.В Аносова»${ }^{1}$.

Постановлением судебной коллегии в составе трех судей Краснодарского краевого суда от 9 июля 2009 года Управлению ФСБ России по Ростовской области было дано разрешение на ограничение прав судьи районного суда города Ростова-на-Дону И.В. Аносова на тайну телефонных и иных переговоров, на неприкосновенность занимаемых им служебных и жилых помещений, служебного и личного автотранспорта и проведение в отношении него соответствующих оперативно-розыскных мероприятий, целью которых являлась проверка информации о действиях И.В. Аносова, содержащих признаки особо тяжкого преступления. Свое обращение в Краснодарский краевой суд Управление ФСБ России по Ростовской области мотивировало тем, что у И.В. Аносова имеются обширные связи в судебных органах Ростовской области, где он работает длительное время, а потому получение в Ростовском областном суде санкции на проведение оперативнорозыскных мероприятий может привести к нарушению режима секретности. 28 июня 2010 года с учетом результатов проведенных оперативно-розыскных мероприятий в отношении И.В. Аносова было возбуждено уголовное дело по признакам преступления, предусмотренного частью третьей статьи 290 УК РФ «Получение взятки».

В своем Постановлении от 9 июня 2011 г. № 12-П Конституционный Суд Российской Федерации отметил, что на процедуру, в которой испрашивается судебное разрешение на проведение оперативно-розыскных мероприятий, связанных с ограничением конституционных прав граждан, не распространяются в полной мере правила, действующие в судебном разбирательстве по уголовному делу и даже в подготовительных действиях к

\footnotetext{
${ }^{1}$ Рос. газ. 2011. 22 июня.
} 
судебному заседанию: в данных правоотношениях еще нет сторон, что характерно для уголовного процесса и в тех случаях, когда, например, уголовное дело возбуждено по факту и лицо, которое совершило преступление, не установлено; в этой процедуре не может быть открытости, гласности и состязательности сторон, проверяемое лицо ее участником не является и знать о ней не должно (определения от 14 июля 1998 года № 86-О, от 24 ноября 2005 года № 448-О, от 8 февраля 2007 года № 1-О и № 128-О-П и др.).

Конституционный Суд Российской Федерации признал положения пункта 7 статьи 16 Закона Российской Федерации «О статусе судей в Российской Федерации» и части первой статьи 9 Федерального закона «Об оперативно-розыскной деятельности», как допускающие рассмотрение материалов о проведении в отношении судьи районного суда оперативнорозыскных мероприятий, связанных с ограничением его гражданских прав или нарушением его неприкосновенности, судебной коллегией в составе трех судей верховного суда республики, краевого, областного суда, суда города федерального значения, суда автономной области, суда автономного округа не по месту проведения оперативно-розыскных мероприятий и не по месту нахождения компетентного органа, ходатайствующего об их проведении, не противоречащими Конституции Российской Федерации, поскольку предполагается, что при наличии обоснованных опасений относительно возможности рассекречивания планируемых оперативно-розыскных мероприятий соответствующие материалы подлежат направлению для рассмотрения в равнозначный суд, который определяется решением Председателя Верховного Суда Российской Федерации или его заместителя, принятым по ходатайству органа, осуществляющего оперативно-розыскную деятельность.

Решение о возбуждении уголовного дела и о привлечении в качестве обвиняемого в отношении члена ЦИК России с правом решающего голоса, председателя избирательной комиссии субъекта Российской Федерации 
принимается Председателем Следственного комитета Российской Федерации, в отношении члена избирательной комиссии, комиссии референдума с правом решающего голоса - руководителем следственного органа Следственного комитета Российской Федерации по субъекту Российской Федерации.

Как представляется, наличие существующих иммунитетов и изъятий из общего порядка уголовного судопроизводства существенно затрудняет принятие решений об осуществлении оперативно-розыскной и следственной деятельности в отношении лиц с особым процессуальным статусом, затягивает производство оперативно-розыскных мероприятий, розыскных и следственных действий, обеспечивает утечку значимой информации, что нередко приводит к сокрытию и уничтожению следов преступлений.

По поручению прокуратуры в период организации и проведения выборов может быть организована проверка законности прекращения производства и отказа в возбуждении уголовных дел в отношении претендующих на власть представителей организованных преступных сообществ и групп.

Должностным лицам правоохранительных органов следует учитывать реальную возможность как обещания материальных и иных благ, так и давление, вплоть до угроз физического уничтожения со стороны отдельных кандидатов.

Как свидетельствует практика, криминальные структуры предоставляют следствию «подставных» свидетелей, оказывают давление на следователей и оперативный состав с помощью коррумпированных связей в органах власти и правоохранительных органах, нанимают высококвалифицированных адвокатов, подкупают и запугивают участников уголовного процесса. С учетом этого усилия необходимо сосредоточить на обеспечении безопасности лиц, ведущих производство по делу, близких и членов семьи сотрудников, судей, используя комплекс мер безопасности, предусмотренный Федеральным законом от 20 апреля 1995 года № 45-Ф3 (с 
изм. и доп.) «О государственной защите судей, должностных лиц правоохранительных и контролирующих органов» ${ }^{1}$.

В соответствии со ст. 5 данного Федерального закона для обеспечения защиты жизни и здоровья защищаемых лиц, сохранности их имущества могут применяться следующие меры безопасности:

1) личная охрана, охрана жилища и имущества;

2) выдача оружия, специальных средств индивидуальной защиты и оповещения об опасности;

3) временное помещение в безопасное место;

4) обеспечение конфиденциальности сведений о защищаемых лицах;

5) перевод на другую работу (службу), изменение места работы (службы) или учебы;

6) переселение на другое место жительства;

7) замена документов, изменение внешности.

При необходимости обеспечить безопасность подозреваемого или обвиняемого, с которым заключено досудебное соглашение о сотрудничестве, его близких родственников и близких лиц применяются меры безопасности, предусмотренные ст. 11 и п.4 ч.2 ст. 241 УПК РФ. На подозреваемого или обвиняемого, с которым заключено досудебное соглашение о сотрудничестве, распространяются все меры государственной защиты потерпевших, свидетелей и иных участников уголовного судопроизводства ${ }^{2}$.

Федеральный закон от 20 августа 2004 года № 119-Ф3 «О государственной защите потерпевших, свидетелей и иных участников уголовного судопроизводства» регламентирует систему мер безопасности и социальной защиты потерпевших, свидетелей и иных участников уголовного процесса (подозреваемых, обвиняемых, подсудимых, их защитников и законных представителей, осужденных, оправданных, лиц, в отношении

\footnotetext{
1 Рос. газ. 1995. 26 апреля.

${ }^{2}$ СТ. 317.9 УПК РФ.
} 
которых уголовное дело либо уголовное преследование было прекращено, частных обвинителей, экспертов, специалистов, переводчиков, понятых, гражданских истцов и ответчиков, их представителей $)^{1}$.

В отношении защищаемого лица могут применяться одновременно несколько либо одна из следующих мер безопасности:

- личная охрана, охрана жилища и имущества;

- выдача специальных средств индивидуальной защиты, связи и оповещения об опасности;

- обеспечение конфиденциальности сведений о защищаемом лице;

- переселение на другое место жительства;

- замена документов;

- изменение внешности;

- изменение места работы (службы) или учебы;

- временное помещение в безопасное место;

- применение дополнительных мер безопасности в отношении защищаемого лица, содержащегося под стражей или находящегося в месте отбывания наказания.

Статья 14 комментируемого Закона устанавливает, что в целях обеспечения безопасности защищаемых лиц, содержащихся под стражей или находящихся в местах отбывания наказания, могут применяться такие меры, как замена документов, изменение внешности, временное помещение в безопасное место, раздельное содержание защищаемого лица, перевод из одного места содержания под стражей или отбывания наказания в другое, изменение меры пресечения или меры наказания.

Необходимость применения мер безопасности можно проиллюстрировать на примере уголовного процесса по факту нападения бандформирований на г. Нальчик 13-14 октября 2005 г. В рамках данного уголовного дела проходит судебное разбирательство по 12 эпизодам вооруженного нападения на г. Нальчик в следующей очередности - СО

\footnotetext{
${ }^{1}$ Рос. газ. 2004. 25 августа.
} 
«Ландыш», МВД по КБР, ОВД №1 г. Нальчика, ОВД № 2 г. Нальчика, Центр «Э» ГУ МВД России по СКФО, магазин «Охотник», УФСБ России по КБР и магазин «Подарки», ОВД № 3 г. Нальчика, УФСИН России по КБР, ОМОН, ПУ ФСБ России по КБР, аэропорт «Нальчик», ППСМ МВД по КБР. С 2009 по 2012 гг. убито 6 свидетелей и сотрудников правоохранительных органов, осуществлявших сопровождение этого уголовного процесса. Факты гибели свидетелей обвинения также отмечались в ходе уголовного процесса в отношении лидера организованного преступного сообщества, депутата Челябинской областной Думы А.Морозова ${ }^{1}$.

Сравнительный анализ мер безопасности, предусмотренных Федеральным законом от 20 апреля 1995 года № 45-Ф3 «О государственной защите судей, должностных лиц правоохранительных и контролирующих органов», и мер безопасности, установленных Федеральным законом от 20 августа 2004 года № 119-Ф3 «О государственной защите потерпевших, свидетелей и иных участников уголовного судопроизводства», свидетельствует о различных правовых режимах применяемых мер государственной защиты.

Во-первых, данные меры безопасности распространяются на различных субъектов.

Во-вторых, в отношении потерпевших, свидетелей и иных участников уголовного судопроизводства применяется ограниченный перечень мер безопасности. Так, переселение на другое место жительства, замена документов, изменение внешности, изменение места работы (службы) или учебы используются в качестве мер безопасности только по уголовным делам о тяжких и особо тяжких преступлениях. Потерпевшим, свидетелям и иным участникам уголовного судопроизводства не выдается оружие. В отличие от судей, должностных лиц правоохранительных и контролирующих органов, конфиденциальные сведения о защищаемых потерпевших, свидетелях и иных

1 «Смелый, решительный, достойный» Александр Морозов получил 20 лет / URL: http://www.kommersant.ru /doc/251939 
участниках уголовного судопроизводства могут предоставляться в органы предварительного расследования, прокуратуру или суд не только в связи с производством по уголовному, но и по гражданскому делу.

В-третьих, реализация предусмотренных для судей, должностных лиц правоохранительных и контролирующих органов мер безопасности обеспечивается проведением оперативно-розыскных мероприятий.

Серьезной проблемой является обеспечение безопасности оперативных источников правоохранительных органов, участвующих в разработке преступных организаций (сообществ).

В силу различных обстоятельств (нарушение конспирации, предательство коррумпированных сотрудников правоохранительных органов и др.) преступникам могут стать известны лица, негласно участвовавшие в оперативно-розыскных мероприятиях. Если «расшифрованный» преступниками источник является штатным сотрудником органа, осуществляющего оперативно-розыскную деятельность, его безопасность должна быть обеспечена в соответствии с Федеральным законом от 20 апреля 1995 г. № 45-Ф3 «О государственной защите судей, должностных лиц правоохранительных и контролирующих органов». На оперативных источников (конфидентов), не являющихся штатными сотрудниками правоохранительных органов, действие данного закона не распространяется.

Если оперативно-розыскная деятельность завершилась возбуждением уголовного дела, возникает необходимость допроса конфидента в качестве свидетеля для применения к нему мер безопасности, предусмотренных Федеральным законом от 20 августа 2004 г. № 119-Ф3 «О государственной защите потерпевших, свидетелей и иных лиц, содействующих уголовному судопроизводству».

Действующее законодательство не регламентирует применение мер безопасности в отношении оперативного источника, когда результаты оперативно-розыскной деятельности не позволили начать уголовное 
преследование преступников, а раскрытый преступниками конфидент не является сотрудником правоохранительных органов.

В теории оперативно-розыскной деятельности предложено следующее решение данной ситуации ${ }^{1}$.

1. Расшифрованный преступниками оперативный источник должен с учетом подследственности заявить в следственный орган об угрозе совершения в отношении него преступных действий из мести за сотрудничество с правоохранительными органами. Такое заявление является поводом для возбуждения уголовного дела и подлежит доследственной провеке.

В этом заявлении или обращении на имя следователя конфидент ходатайствует о применении к нему мер безопасности, предусмотренных Федеральным законом от 20 августа 2004 г. № 119-Ф3 «О государственной защите потерпевших, свидетелей и иных лиц, содействующих уголовному судопроизводству».

2. Следователь на основании заявления конфидента выносит постановление о применении мер безопасности и направляет его для исполнения в соответствующее территориальное подразделение Управления по обеспечению безопасности лиц, подлежащих государственной защите.

В целях совершенствования нормативно-правовой защиты лиц, оказывающих содействие правоохранительным органам, предлагается наделить полномочиями по применению мер безопасности, предусмотренных Федеральным законом от 20 августа 2004 г. № 119-Ф3 «О государственной защите потерпевших, свидетелей и иных лиц, содействующих уголовному судопроизводству», не только следователя и иных лиц, в производстве которых находятся сообщения о преступлениях и уголовные дела, но и руководителей подразделений, осуществляющих

${ }^{1}$ Брусницын Л.В. Как защитить конфидента при провале оперативно-разыскного мероприятия? // Оперативник (сыщик). 2013. № 3 (36). С. 15-16. См. также Брусницыьн Л.В. Об отсутствии гарантий безопасности граждан, сотрудничающих с правоохранительными органами // Оперативник (сыщик). 2010. № 1. С. 10. 
оперативно-розыскную деятельность, подобно тому, как это сделано, например, в Австралии, Австрии, Великобритании, Канаде, Латвии, Нидерландах, Норвегии и Украине. Данное изменение законодательства является необходимым условием для защиты граждан, оказывающих содействие в осуществлении оперативно-розыскной деятельности по линии разработки преступных организаций (сообществ) ${ }^{1}$.

Важную роль в реализации антикриминальной политики в процессе организации и проведения выборов играют контрольно-ревизионные службы избирательных комиссий. Откомандированные в них сотрудники правоохранительных и иных государственных органов оказывают содействие избирательным комиссиям в установленных законодательством формах (контроль за целевым расходованием денежных средств, выделенных комиссиям на проведение выборов; контроль за источниками поступления, правильным учетом и использованием денежных средств избирательных фондов; проверка финансовых отчетов кандидатов, избирательных объединений; проверка достоверности представленных кандидатами сведений; пресечение противоправной агитационной деятельности; контроль за возвратом бюджетных средств, выделенных в избирательные фонды зарегистрированных кандидатов, избирательных объединений).

Значимость работы контрольно-ревизионных служб избирательных комиссий по проверке достоверности представленных кандидатами сведений о доходах и имуществе можно показать на примере федеральных выборов депутатов Государственной Думы Федерального Собрания Российской Федерации пятого и шестого созывов.

В рамках данного исследования автором проведен анализ имеющихся в федеральных партийных списках и документах избирательных комиссий сведений об источниках доходах и имуществе кандидатов, выдвинутых политическими партиями, принимавшими участие в выборах депутатов

${ }_{1}^{1}$ Бруснищьл Л.В. Как защитить конфидента при провале оперативно-разыскного мероприятия? // Оперативник (сыщик). 2013. № 3 (36). С. 15-16. 
Государственной Думы Федерального Собрания Российской Федерации пятого и шестого созывов ${ }^{1}$.

$\mathrm{B}$ списке Коммунистической партии Российской Федерации на выборах депутатов Государственной Думы Федерального Собрания Российской Федерации пятого созыва отсутствовали сведения об источниках доходов, вкладах в банках, ценных бумагах и имуществе на праве собственности в отношении 2 кандидатов ${ }^{2}$.

3 кандидата СПРАВЕДЛИВОЙ РОССИИ не представили никаких сведений о доходах и имуществе 3 .

В зарегистрированном федеральном списке Либеральнодемократической партии России отсутствовали сведения о доходах и имуществе 4 кандидатов ${ }^{4}$.

Вызывает вопрос достоверность сведений об источниках доходов, вкладах в банках, ценных бумагах и имуществе на праве собственности ректора АНО ВПО «Институт мировых цивилизаций» Б., который при общем доходе в 440 тысяч рублей приобрел в собственность жилые дома во Владимирской, Курской и Челябинской областях, квартиры в Республике Саха, Ставропольском и Камчатском краях, Архангельской, Белгородской, Владимирской, Вологодской, Ивановской, Иркутской, Кемеровской, Курганской, Московской, Новосибирской, Томской, Тульской, Челябинской, Читинской областях и городе Москве 5

${ }^{1}$ В двух электоральных циклах федеральных выборов 2007 и 2011 гг. участвовали «Коммунистическая партия Российской Федерации», «СПРАВЕДЛИВАЯ РОССИЯ», «Либерально-демократическая партия России», «ЕДИНАЯ РОССИЯ», Российская объединенная демократическая партия «ЯБЛОКО» и «ПАТРИОТЫ РОССИИ». Списки этих партий, главным образом, и являлись предметом сравнительного исследования.

2 Сведения о размере и об источниках доходов, имуществе, принадлежащем кандидатам на праве собственности, о вкладах в банках, ценных бумагах (на основании данных, представленных кандидатами) // Рос. газ. 2007. 2 декабря. С. 120.

\footnotetext{
${ }^{3}$ Там же. С. $151,154$.

${ }^{4}$ Там же. C. $139,140,142$.

5 Там же. С. 138.
} 
В списке «ЕДИНОЙ РОССИИ» отсутствовали сведения о доходах и имуществе 1 кандидата ${ }^{1}$.

На федеральных выборах 2007 года список партии «ПАТРИОТЫ РОССИИ» имел максимальное количество кандидатов, не предоставивших сведения об источниках доходов, вкладах в банках, ценных бумагах и имуществе на праве собственности - 13. В их числе: третье лицо в федеральной части списка и 3 депутата муниципальных и региональных представительных органов власти ${ }^{2}$.

В списке партии «ЯБЛОКО» на выборах депутатов Государственной Думы Федерального Собрания Российской Федерации пятого созыва отсутствовали сведения об источниках доходов, вкладах в банках, ценных бумагах и имуществе на праве собственности в отношении 2 кандидатов ${ }^{3}$.

Кандидат X. утаил сведения или забыл о двух магазинах в Ярославской области, земельных участках в Ярославской области размером 1259 кв.м и 732 кв.м, торговых площадях в здании торгового комплекса размером 202, 2 кв.м и 225 кв.м4. К. не сообщил о 18 земельных участках в Псковской области общей площадью 1 млн. 31 тыс. 395 кв.м5.

Сравним данные 2007 года со сведениями об источниках доходов, вкладах в банках, ценных бумагах и имуществе на праве собственности, представленными кандидатами на федеральных выборах 2011 года.

Ряд кандидатов из федерального списка политической партии СПРАВЕДЛИВАЯ РОССИЯ на выборах депутатов Государственной Думы Федерального Собрания Российской Федерации шестого созыва не имел никаких источников доходов, вкладов в банках, ценных бумаг и имущества на праве собственности. В качестве примера можно привести депутата, Заместителя Председателя комитета Народного Собрания Республики Дагестан по делам молодежи, спорту и туризму П., заместителя генерального

\footnotetext{
${ }^{1}$ Там же. С. 174.

${ }^{2}$ Там же. С. $155,156,157,160,161$.

${ }^{3}$ Там же. С. $175,177$.

${ }^{4}$ Там же. С. 208.

${ }^{5}$ Там же. С. 208.
} 
директора ООО «Регионгазлизинг», депутата Законодательного Собрания Пермского края на непостоянной основе Л., Секретаря Бюро Совета регионального отделения в Пермском крае Б., генерального директора ООО «Корпорация «Гринвич», депутата Законодательного Собрания Пермского края на непостоянной основе М. ${ }^{1}$.

У Либерально-демократической партии России также присутствовали «малоимущие» и «бездомные» кандидаты. 6 из них не имели никаких источников доходов, вкладов в банках, ценных бумаг и имущества на праве собственности ${ }^{2}$.

По сравнению с зарегистрированным списком на федеральных выборах 2007 года, в списке партии «ПАТРИОТЫ РОССИИ» 2011 г. заметно сократилось число кандидатов, не предоставивших сведения об источниках доходов, вкладах в банках, ценных бумагах и имуществе на праве собственности. У 3 кандидатов не было никакого имущества на праве собственности, кроме автомобиля ${ }^{3}$. Никаких сведений о размере и об источниках доходов не указал только 1 кандидат ${ }^{4}$.

В тоже время кандидат А. не упомянул о благоустроенной промплощади 1 295,20 кв.м (по наружному обмеру) и тепловых сетях (544, 4 кв.м) в г. Омске, а также о транспортных средствах: ГАЗ 3302 (2005), ГАЗ 3302 (2006), ЗИЛ 431412 (2006), ЗИЛ 431410 (2006), ГАЗ 3302 (2006), ГАЗ 3302 (2006), Mitsubishi Canter (2009), ГАЗ 330210 (2003), KAMA3 5320 (2004), АФ 47821А (2011), ЗИЛ 431410 (2006), ГАЗ 3302 (2004), ЗИЛ ММЗ 554 (2011), КАМАЗ 53212 (2011), ГАЗ 3302 (2004), ЗИЛ 433360 (2010), ЗИЛ 433360 (2010), 2775-01 (2009), 270710 (2009), 270701 (2009), ГАЗ 3302 (2007), ЗИЛ 433362 (2004), ЗИЛ 433362 (2007), ЗИЛ 5301Б0 (2007), ЗИЛ 5301Б0

1 Сведения о размере и об источниках доходов, имуществе, принадлежащем кандидатам на праве собственности, о вкладах в банках, ценных бумагах (на основании данных, представленных кандидатами) // Рос. газ. 2011. 4 декабря. С. 94, 97, 110.

${ }^{2}$ Там же. С. $111,114,115,116$.

${ }^{3}$ Там же. С. $118,119,120,123$.

${ }^{4}$ Там же. С. 118. 
(2007), 27901-000010-21 (2009), ЗИЛ 130 (2009), КАМАЗ 5320 (2008), ЗИЛ 431412 (2010) и ГАЗ $3302(2006)^{1}$.

В отличие от федеральных выборов 2007 года, в федеральном списке кандидатов на выборах депутатов Государственной Думы Федерального Собрания Российской Федерации шестого созыва Коммунистической партии Российской Федерации кандидаты, не указавшие никаких сведений о размере и об источниках доходов, отсутствовали.

Однако кандидат А. «забыл» о четырех земельных участках в Карачаево-Черкесской Республике (10 000 кв.м; 648000 кв.м; 60000 кв.м; 1540 кв.м), земельном участке в Ставропольском крае (600 кв.м) и жилом объекте (33,8 кв.м) в Карачаево-Черкесской Республике ${ }^{2}$.

В. не указал три земельных участка в Ханты-Мансийском автономном округе (1 231 кв.м; 900 кв.м; 28 кв.м), две квартиры в Тюменской области (167 кв.м и 76,9 кв.м), часть жилого дома (83,9 кв.м), жилое помещение (42,7 кв.м), три здания (строения) в Ханты-Мансийском автономном округе (26 кв.м; 48 кв.м; 28 кв.м) и три здания в Тюменской области (48,3 кв.м; 192,7 кв.м; 31,2 кв.м $)^{3}$.

Г. не указал нежилые помещения в Краснодарском крае (5 кв.м; 109, 7 кв.м; 38 кв.м; 53,4 кв.м; 681,6 кв.м; 15,8 кв.м; 241, 7 кв.м; 37, 6 кв.м; 39, 7 кв.м; 99,1 кв.м; 38, 5 кв.м; 107,9 кв.м; 31, 7 кв.м; 83, 6 кв.м; 101, 5 кв.м; 38, 2 кв.м; 38, 8 кв.м; 105, 3 кв.м; 101, 9 кв.м; 36, 5 кв.м; 298, 5 кв.м; 36, 4 кв.м; 38, 2 кв.м; 102, 5 кв.м; 36, 6 кв.м; 155, 7 кв.м; 36.9 кв.м; 102, 1 кв.м; 37, 4 кв.м; 36, 7 кв.м; 37, 1 кв.м; 365, 5 кв.м; 684, 8 кв.м; 209, 6 кв.м; 106, 2 кв.м ${ }^{4}$

1 Сведения о размере и об источниках доходов, имуществе, принадлежащем кандидатам на праве собственности, о вкладах в банках, ценных бумагах (на основании данных, представленных кандидатами) // Рос. газ. 2011. 4 декабря. С. 192.

${ }^{2}$ Там же. С. 195.

${ }^{3}$ Там же. С. 195.

4 Сведения о размере и об источниках доходов, имуществе, принадлежащем кандидатам на праве собственности, о вкладах в банках, ценных бумагах (на основании данных, представленных кандидатами) // Рос. газ. 2011. 4 декабря. С. 195. 
В списке Российской объединенной демократической партии «ЯБЛОКО» не было сведений об имуществе, вкладах, ценных бумагах и источниках доходов 3 кандидатов ${ }^{1}$.

В списке Всероссийской политической партии «ЕДИНАЯ РОССИЯ», как и у Коммунистической партии Российской Федерации, кандидатов, не указавших никаких сведений о размере и об источниках доходов, не было.

Вызывает сомнение достоверность сведений об источниках доходов, вкладах в банках, ценных бумагах и имуществе на праве собственности президента ООО «Новые технологии» Н., которая при общем доходе в 408 тысяч рублей имеет в собственности земельные участки в Московской области (1221 кв.м - совместная собственность), жилой дом в Московской области (284,9 кв.м - совместная собственность), квартиру в г. Москва (92,9 кв.м - совместная собственность), легковые автомобили «Ламборгини диабло» (1994 г.), БМВ 540 (1998 г.), вклады в банках: ОАО «АКБ «Росевробанк» - 679 тыс. 195 рублей 12 копеек; акции ООО «Ка-Фур» - 80\%, ООО «Компания Каскад-Виа» - 100\%, ООО «Каскад ВИА-М» - 100\%, ЗАО «Брэйн и К» - 1320 акций, ООО «Кирпичный завод «Понежукайский» (Адыгея) - 60\%, ООО «Недра Кубани»- 50\%, ООО «Твой Новый Дом» $51 \%$, ООО «Золотой крендель» - 100\%, ООО «Логистическая компания» 100\%, ООО «ЕвроИндустрия» - 100\%, ООО «Профессиональная Информация» - 100\%, ООО «Комбинат нерудных материалов «Теучежский» - 50\%, 3АО «Компания Пластика» - 80 акций, ООО «К-Финанс» - 100\%, ООО «ЛонгЛайф» - 70\%, ООО «ТехРечФлот» - 2\%, ЗАО «Хоббит» - 450 тыс. акций, ЗАО «Профиль-Сервис» - 75 акций, ЗАО «Лэми» - 325 акций, ООО «Астер-М» - 100\%, ООО «Диамант» - 50\%, ООО «Новые Технологии» - 70\%, ООО «К-Фикс Консалт» - 100\%, ООО «ТST- групп» - 100\%, ООО «Профпласт-Екатеринбург»- $100 \% .^{2}$

${ }^{1}$ Там же. С. 139, 144, 145.

2 Сведения о размере и об источниках доходов, имуществе, принадлежащем кандидатам на праве собственности, о вкладах в банках, ценных бумагах (на основании данных, представленных кандидатами) // Рос. газ. 2011. 4 декабря. С. 161. 
У Всероссийской политической партии «ПРАВОЕ ДЕЛО» сведения о размере и об источниках доходов, вкладах в банках, ценных бумагах и имуществе на праве собственности не представили 6 кандидатов ${ }^{1}$.

Кандидат партии «ПРАВОЕ ДЕЛО» Б. не сообщил о принадлежащем ему жилом помещении в г. Краснодар площадью 64,4 кв.м, а также о нежилых помещениях в г. Сочи площадью 938,9 кв.м (доля в праве 1/3), 362,5 кв.м (доля в праве 1/3), 2854 кв.м (доля в праве 1/3) и 1320,6 кв.м (доля в праве $1 / 3)^{2}$.

Г. не упомянула о 3-х комнатной квартире (67,27 кв.м), 2-х комнатной (42,7 кв.м) и 1-комнатной (40,5 кв.м) квартирах в г. Кострома 3 .

Кандидат И. «забыл» о принадлежащем ему подъезде к г. Элиста от автодороги М-6 «Каспий», жилых помещениях в г. Элиста площадью 89 кв.м и 151,2 кв.м, производственных помещениях в г. Элиста (224,63 кв.м, 292,49 кв.м и 365,3 кв.м), нежилых помещениях в г. Элиста (318,39 кв.м, 292,75 кв.м, 24,24 кв.м, 1711,7 кв.м, 19,5 кв.м), землях населенных пунктов в г. Элиста (3384 кв.м, 4428 кв.м, 4024 кв.м, 1828 кв.м, 946 кв.м, 18456 кв.м, 421 кв.м, 2306 кв.м $)^{4}$.

П. не сообщил о земельных участках в д. Крупшево Калининского района Тверской области площадью 24000 кв.м, 41000 кв.м, 75000 кв.м, 66000 кв.м, 60390 кв.м и 61935 кв.м.

М. не упомянул о принадлежащей ему барже 3985 ББ 2004 года 6 .

На выборах депутатов Государственной Думы Федерального Собрания Российской Федерации 2011 г. максимальное количество кандидатов, подавших недостоверные сведения о размере и об источниках доходов, было в федеральном списке политической партии СПРАВЕДЛИВАЯ РОССИЯ -

${ }^{1}$ Там же. С. $172,175,176,178$.

${ }^{2}$ Там же. С. 200.

${ }^{3}$ Там же. С. 200.

${ }^{4}$ Там же. С. 200.

5 Сведения о размере и об источниках доходов, имуществе, принадлежащем кандидатам на праве собственности, о вкладах в банках, ценных бумагах (на основании данных, представленных кандидатами) // Рос. газ. 2011. 4 декабря. С. 200.

${ }^{6}$ Там же. С. 200. 
134. 15 кандидатов Справедливой России представили недостоверные сведения о недвижимом имуществе, 2 - о транспортных средствах ${ }^{1}$.

38 кандидатов Либерально-демократической партии России указали недостоверные сведения о доходах, 3 - о недвижимом имуществе, 3 - о транспортных средствах ${ }^{2}$.

57 кандидатов политической партии «ПАТРИОТЫ РОССИИ» предоставили недостоверные сведения о доходах, 20 - о недвижимом имуществе, 10 - о транспортных средствах 3 .

94 кандидата политической партии «Коммунистическая партия Российской Федерации» указали недостоверные сведения о доходах, 22 - о недвижимом имуществе, 13 - о транспортных средствах ${ }^{4}$.

Недостоверные сведения о доходах предоставили 74 кандидата Российской Объединенной демократической партии «ЯБЛОКО», 18 кандидатов указали неверные сведения о недвижимом имуществе, 6 - о транспортных средствах 5 .

52 кандидата Всероссийской политической партии «ПРАВОЕ ДЕЛО» указали недостоверные сведения о доходах, 27 - о недвижимом имуществе, 1 - о транспортных средствах 6 .

Минимальное количество кандидатов, указавших недостоверные сведения о своих доходах и недвижимом имуществе, было в федеральном списке Всероссийской политической партии «ЕДИНАЯ РОССИЯ» (3 и 6 соответственно). Недостоверных сведений о транспортных средствах кандидатами Единой России представлено не было 7

1 Там же. С. 187-190.

${ }^{2}$ Там же. С. С. 190.

${ }^{3}$ Там же. С. 191-192.

${ }^{4}$ Там же. С. 193-196.

${ }^{5}$ Там же. С. 196-198.

6 Сведения о размере и об источниках доходов, имуществе, принадлежащем кандидатам на праве собственности, о вкладах в банках, ценных бумагах (на основании данных, представленных кандидатами) // Рос. газ. 2011. 4 декабря. С. 199-200.

7 Там же. С. 198. 
Следует подчеркнуть, что непредоставление кандидатами сведений о своих доходах и имуществе либо предоставление недостоверных сведений могут не иметь никакого отношения к криминальному прошлому (настоящему) кандидатов и нарушению ими порядка финансирования избирательной кампании. Причинами подобной небрежности могут являться как забывчивость и технические ошибки кандидатов, так и необходимость сознательного введения организаторов выборов и избирателей в заблуждение. В любом случае, выявленные контрольно-ревизионными службами избирательных комиссий факты недостоверных сведений о кандидатах, свидетельствуют о «качестве» депутатского корпуса, юридической «чистоте» народных представителей и отношении будущих депутатов к своему электорату. В связи с этим недопустим формальный подход руководства избирательных комиссий и должностных лиц правоохранительных органов к проверке материального положения кандидатов, источникам происхождения их доходов, произведенным в период избирательной кампании расходам, а также связям кандидатов с представителями преступного мира, подконтрольными криминальным структурам организациями и кредитными учреждениями.

Думается, что повысить ответственность политических партий, кандидатов в депутаты и улучшить качество народного представительства можно было бы, вернувшись к практике исключения кандидатов из партийных списков за предоставление ими недостоверных сведений и подложных документов. Представление кандидатом подложных документов или заведомо ложных сведений следовало бы закрепить в качестве основания отказа в регистрации и отмены регистрации кандидата судом.

Усиление требований к замещению государственных должностей Российской Федерации, государственных должностей субъектов Российской Федерации, должностей гражданской, военной, правоохранительной и муниципальной службы в т.ч. в части представления сведений о доходах, расходах, об имуществе и обязательствах имущественного характера должно 
системно дополняться правовыми механизмами регулярного проведения антикоррупционных (антикриминальных) расследований.

Антикоррупционные (антикриминальные) расследования связаны с изучением фактов и обстоятельств, имеющих негативные последствия для криминогенной обстановки и состояния законности в государстве.

В предмет антикоррупционных (антикриминальных) расследований должны входить:

1) факты коррупционных проявлений в органах государственной власти и местного самоуправления, правоохранительных и контрольноревизионных органах, государственных корпорациях, государственных и муниципальных учреждениях;

2) обстоятельства, связанные с избранием лиц, причастных к организованной преступной деятельности, в законодательные органы власти, выборные органы местного самоуправления, представительные органы муниципальных образований, на выборные должности;

3) обстоятельства, связанные с назначением лиц, причастных к организованной преступной деятельности, на государственные должности Российской Федерации, государственные должности субъектов Российской Федерации, муниципальные должности, должности правоохранительной и военной службы, должности в государственных корпорациях, государственных и муниципальных учреждениях;

4) факты лоббирования должностными лицами органов государственной власти и местного самоуправления, правоохранительных и контрольно-ревизионных органов, государственных корпораций, государственных и муниципальных учреждений интересов предприятий, организаций, учреждений и бизнес-структур, принадлежащих или аффилированных с лицами, причастными к организованной преступной деятельности;

5) факты нелегального финансирования избирательных кампаний кандидатов, избирательных объединений, легализации преступных доходов, 
грубого нарушения финансовой дисциплины, выразившиеся в нецелевом расходовании бюджетных средств и средств государственных внебюджетных фондов, неправомерного получения кредитов, управления и распоряжения федеральной, региональной и муниципальной собственностью.

Данные расследования не подменяют собой дознание, предварительное следствие и судопроизводство.

Антикоррупционные (антикриминальные) расследования могут осуществляться Общественной палатой Российской Федерации, Общественными палатами субъектов Российской Федерации, Уполномоченным по правам человека в Российской Федерации, Уполномоченными по правам человека в субъектах Российской Федерации, антикоррупционными общественными организациями.

Несовершенство существующей процедуры антикоррупционных (антикриминальных) расследований связано с неурегулированностью правового статуса участников расследования, вопросов финансового, материально-технического и иного обеспечения расследования, порядка организации взаимодействия общественных институтов с государственными (муниципальными) органами, привлекаемыми к расследованию, а также рекомендательным характером проведенного расследования.

На наш взгляд, организационной формой подобных расследований должна стать деятельность комиссии, созданной инициаторами антикоррупционного (антикриминального) расследования. Данную комиссию предлагается наделить правами: запрашивать у государственных и муниципальных органов, учреждений и организаций документы и информацию, необходимые для расследования; приглашать для дачи объяснений по расследуемым фактам и обстоятельствам должностных лиц, экспертов, специалистов; выезжать на место расследуемых событий. Финансовое и материально-техническое обеспечение может осуществляться за счет бюджетных средств, выделяемых на обеспечение деятельности общественных палат, уполномоченных по правам человека. 
По результатам антикоррупционного (антикриминального) расследования комиссия готовит доклад, который публикуется в установленном порядке, размещается в сети Интернет и направляется Президенту Российской Федерации (высшему должностному лицу субъекта Российской Федерации), в палаты Федерального Собрания Российской Федерации (законодательный орган государственной власти субъекта Российской Федерации), Правительство Российской Федерации, Председателю Следственного комитета Российской Федерации (руководителю следственного органа Следственного комитета по субъекту Российской Федерации), Генеральному прокурору Российской Федерации (прокурору субъекта Российской Федерации). В итоговом докладе комиссии могут содержаться предложения Президенту Российской Федерации (высшему должностному лицу субъекта Российской Федерации) об освобождении должностных лиц от замещаемых должностей, предложения о совершенствовании нормативных правовых актов, организационнопрактические меры оптимизации деятельности органов государственной власти и местного самоуправления, правоохранительных и контрольноревизионных органов, государственных корпораций, государственных и муниципальных учреждений в части устранения причин и условий, способствующих коррупционным проявлениям, вытеснения представителей криминалитета из данных структур. О принятом по докладу решении Президент Российской Федерации (высшее должностное лицо субъекта Российской Федерации) в месячный срок уведомляет инициатора антикоррупционного (антикриминального) расследования.

В соответствии с Федеральным законом от 17 июля 2009 г. № 172-Ф3 «Об антикоррупционной экспертизе нормативных правовых актов и проектов нормативных правовых актов» составной частью общегосударственного механизма противодействия коррупции является антикоррупционная экспертиза нормативных правовых актов и проектов нормативных правовых 
актов $^{1}$. Федеральный закон от 17 июля 2009 г. № 172-Ф3 закрепил обязательность проведения антикоррупционной экспертизы проектов нормативных правовых актов; необходимость оценки нормативного правового акта во взаимосвязи с другими нормативными правовыми актами; принципы обоснованности, объективности и проверяемости результатов антикоррупционной экспертизы нормативных правовых актов; требования к компетентности лиц, проводящих антикоррупционную экспертизу нормативных правовых актов (проектов нормативных правовых актов); приоритет сотрудничества разработчиков нормативных правовых актов с институтами гражданского общества при проведении антикоррупционной экспертизы нормативных правовых актов.

Процедуры антикоррупционной экспертизы нормативных правовых актов детализированы в Постановлении Правительства Российской Федерации от 26 февраля 2010 года № 96 «Об антикоррупционной экспертизе нормативных правовых актов и проектов нормативных правовых актов», в котором предусмотрены четыре правовых режима антикоррупционной экспертизы².

Первый режим антикоррупционной экспертизы распространяется на проекты федеральных законов и подзаконных актов федеральных органов исполнительной власти, иных государственных органов и организаций. Коррупциогенные нормы правовых актов проверяются и устраняются в ходе их правовой экспертизы.

Второй правовой режим включает проекты концепций и технических заданий на разработку проектов федеральных законов, проекты поправок Правительства Российской Федерации к проектам федеральных законов, подготовленным федеральными органами исполнительной власти, иными государственными органами и организациями. Коррупциогенные нормы проверяются и устраняются в ходе их правовой экспертизы.

\footnotetext{
${ }^{1}$ Рос. газ. 2009. 22 июля.

2 Рос. газ. 2010. 5 марта.
} 
Третий правовой режим касается нормативных правовых актов федеральных органов исполнительной власти, иных государственных органов и организаций, затрагивающих права, свободы и обязанности человека и гражданина, устанавливающих правовой статус организаций или имеющих межведомственный характер, а также уставов муниципальных образований и муниципальных правовых актов о внесении изменений в уставы муниципальных образований. Антикоррупционная экспертиза правовых актов осуществляется при их государственной регистрации.

Четвертый правовой режим антикоррупционной экспертизы охватывает нормативные правовые акты субъектов Российской Федерации и реализуется при мониторинге их применения.

Потребности совершенствования правовых норм в контексте противодействия коррупции существуют в большинстве отраслей. Не является исключением и избирательное законодательство. Законодательные и подзаконные акты о выборах, как и другие нормативные регуляторы российской правовой системы, нуждаются в антикоррупционной экспертизе, что обусловливает актуальность изучения коррупциогенных факторов нормативных правовых актов о выборах ${ }^{1}$.

24 ноября 2010 года ЦИК России утвердила Порядок проведения антикоррупционной экспертизы нормативных правовых актов и проектов нормативных правовых актов в Центральной избирательной комиссии Российской Федерации, которая будет осуществляться в соответствии с Постановлением Правительства Российской Федерации от 26 февраля 2010 года № 96. В принятом документе регламентированы действия по

${ }^{1}$ Бородин С.В., Лунеев В.В. О криминологической экспертизе законов и иных нормативных актов // Государство и право. 2002. № 6. С. 41; Постников А.Е. Избирательное законодательство: необходимо четкое разделение полномочий между различными уровнями власти при проведении выборов // Журнал российского права. 2002. № 5. С. 21-22; Кабанов П.А., Райков Г.И., Чирков Д.К. Политическая коррупция в условиях реформирования российской государственности на рубеже веков: Монография. М.: Дружба народов, 2008. С. 107; Мальиеев Г.В., Носов С.И. Коррупциогенные факторы в юридических нормах: природа, формы проявления, проблемы устранения // Право и образование. 2009. № 1. С. 4-12. 
проведению мониторинга применения правовых актов на предмет выявления в них коррупциогенных факторов ${ }^{1}$.

В качестве коррупциогенных факторов ЦИК России рассматривает правовые пробелы, положения нормативных правовых актов (проектов нормативных правовых актов), устанавливающие для правоприменителя необоснованно широкие пределы усмотрения или возможность необоснованного применения исключений из общих правил, а также положения, содержащие неопределенные, трудновыполнимые и (или) обременительные требования к гражданам и организациям и тем самым создающие условия для проявления коррупции.

В отличие от ранее действовавшей Методики проведения экспертизы проектов нормативных правовых актов и иных документов в целях выявления в них положений, способствующих созданию условий для проявления коррупции, утвержденной Постановлением Правительства Российской Федерации от 5 марта 2009 г. № 196, Постановлением Правительства Российской Федерации от 26 февраля 2010 года № 96 из числа коррупциогенных факторов устранены: отсутствие в акте положений о раскрытии информации о деятельности органов власти; отсутствие запретов, ограничений и мер ответственности для госслужащих; отсутствие возможности контроля, в том числе общественного, за действиями госорганов и должностных лиц; нормативные коллизии ${ }^{2}$ Такое решение законодателя представляется ошибочным. Логически очень сложно обосновать, что противоречия в правовых положениях, отсутствие ограничений и мер ответственности госслужащих, отсутствие контроля за деятельностью госорганов и должностных лиц не затрагивают

${ }^{1}$ Постановление ЦИК России от 24 ноября 2010 г. № 228/1503-5 «Об утверждении Порядка проведения антикоррупционной экспертизы нормативных правовых актов и проектов нормативных правовых актов в Центральной избирательной комиссии Российской Федерации» // Вестник Центральной избирательной комиссии Российской Федерации. 2010. № 11.

${ }^{2}$ СЗ РФ. 2009. № 10. Ст. 1241. 
коррупционных проявлений. Любая правореализация доказывает как раз обратное.

В Порядке проведения антикоррупционной экспертизы нормативных правовых актов и проектов нормативных правовых актов в Центральной избирательной комиссии Российской Федерации урегулирована ситуация, связанная с истребованием правовых актов у организаций, созданных при ЦИК России (Федеральный центр информатизации при ЦИК России и Российский центр обучения избирательным технологиям при ЦИК России). При проведении антикоррупционной экспертизы документов предусмотрено сотрудничество ЦИК России с Генеральной прокуратурой Российской Федерации и с институтами гражданского общества. В случаях выявления коррупциогенных факторов в нормативных правовых актах соответствующие вопросы подлежат вынесению на заседание ЦИК России. Для проведения независимой антикоррупционной экспертизы проект нормативного правового акта должен размещаться на официальном сайте ЦИК России с указанием дат начала и окончания приема заключений по результатам независимой антикоррупционной экспертизы.

Необходимость работы по дальнейшему повышению качества нормативной правовой базы определяется тем, что в законодательстве Российской Федерации до настоящего времени не предусмотрена юридическая ответственность за разработку и принятие должностными лицами органов государственной власти субъектов Российской Федерации, органов местного самоуправления нормативных правовых актов, противоречащих Конституции Российской Федерации, федеральным конституционным и федеральным законам, содержащих коррупционные нормы, повлекших за собой нарушения прав и свобод граждан, угрозу единству и территориальной целостности, обороноспособности государства, единству правового и экономического пространства. В связи с изложенным, представляется важным закрепление соответствующих уголовно-правовых 
норм и продолжение работы по восполнению пробелов в правовом регулировании и устранению коррупционных факторов.

Представляется, что данное направление противодействия криминализации органов публичной власти обладает существенным потенциалом. Проведение антикоррупционной экспертизы нормативных правовых актов о выборах и проектов таких актов позволит повысить уровень доверия избирателей, кандидатов и политических партий к органам власти, будет способствовать укреплению законности федеральных, региональных и муниципальных выборов в Российской Федерации.

Условием успешного проведения антикоррупционной (антикриминальной) работы является четкая организация взаимодействия общественных институтов с налоговыми органами, органами федеральной службы безопасности, Счетной Палаты, федеральной службы по финансовому мониторингу, надзорными органами, кредитными организациями и органами, осуществляющими государственную регистрацию прав на недвижимое имущество и сделок с ним.

В равной мере это относится к проверке контрольно-ревизионными службами достоверности предоставляемых кандидатами сведений, противодействию нелегальному финансированию избирательных кампаний кандидатов, избирательных объединений, попыткам легализации преступных доходов.

Контрольно-ревизионные службы также рассматривают представления избирательных комиссий о нарушениях законодательства, проверяют наличие у кандидатов неснятых (непогашенных) судимостей, запрашивают материалы оперативно-справочных учетов ФГБУ ГИАЦ МВД России, информационных центров МВД, ГУВД, УВД субъектов Российской Федерации в отношении обвиняемых в совершении преступлений, осужденных, разыскиваемых.

При осуществлении мероприятий по противодействию криминализации органов публичной власти обязателен тесный контакт со СМИ, предоставление журналистам имеющейся информации о наличии у 
кандидатов криминального прошлого или тесных связей с организованной преступностью, широкое освещение доказанных фактов противоправной деятельности ${ }^{1}$. В то же время организаторам выборов и правоохранительным органам нельзя допускать ведения «войны компроматов», использования в период выборов «грязных» избирательных технологий.

В формате правоприменительной практики противодействия криминалитету необходимо отметить наличие в российском законодательстве конституционно-правовых антикриминальных механизмов.

Так, для отрешения от должности высшего должностного лица субъекта Российской Федерации можно использовать существующую в федеральном законодательстве и законодательстве субъекта Федерации возможность досрочного прекращения полномочий в связи с утратой доверия Президента Российской Федерации.

Согласно статье 19 Федерального Закона «Об общих принципах организации законодательных (представительных) и исполнительных органов государственной власти субъектов Российской Федерации» основанием для утраты доверия Президента Российской Федерации является:

- выявление в отношении высшего должностного лица субъекта Российской Федерации (руководителя высшего исполнительного органа государственной власти субъекта Российской Федерации) фактов коррупции; - неурегулирование конфликта интересов как правонарушений, предусмотренных Федеральным законом от 25 декабря 2008 года N 273-Ф3 «О противодействии коррупции»;

- установление в отношении высшего должностного лица субъекта Российской Федерации фактов открытия или наличия счетов (вкладов), хранения наличных денежных средств и ценностей в иностранных банках, расположенных за пределами территории Российской Федерации, владения и

1 Эффективным примером взаимодействия правоохранительных органов со СМИ является публикация 17, 18 и 19 сентября 1997 года в газете «Известия» статьи «Время Быков», в которой приводились факты участия мэра г. Ленинска-Кузнецкого Кемеровской области Коняхина Г.В. и членов его организованной преступной группы в убийствах и других криминальных эпизодах. 
(или) пользования иностранными финансовыми инструментами в период, когда такое лицо являлось зарегистрированным кандидатом на данную должность.

Полномочия высшего должностного лица субъекта Российской Федерации также могут быть прекращены досрочно в результате инициирования его отзыва избирателями, зарегистрированными на территории субъекта Российской Федерации.

Отзыв высшего должностного лица субъекта Российской Федерации возможен по одному из следующих оснований:

a) нарушение высшим должностным лицом субъекта Российской Федерации законодательства Российской Федерации и (или) законодательства субъекта Российской Федерации, факт совершения которого установлен соответствующим судом. Отзыв по данному основанию не освобождает высшее должностное лицо субъекта Российской Федерации от иной ответственности;

б) неоднократное грубое без уважительных причин неисполнение высшим должностным лицом субъекта Российской Федерации своих обязанностей, установленное соответствующим судом.

Процедура отзыва высшего должностного лица субъекта Российской Федерации включает:

перечень субъектов, которые вправе обратиться в верховный суд республики, краевой, областной суд, суд города федерального значения, суд автономной области и суд автономного округа с заявлением об установлении оснований отзыва (политические партии, их региональные отделения, иные общественные объединения, а также группа граждан Российской Федерации в количестве не менее 100 человек, проживающих на территории соответствующего субъекта Федерации и обладающих активным избирательным правом);

сбор подписей в поддержку инициативы голосования по отзыву; 
проверку комиссией по отзыву соблюдения порядка сбора подписей в поддержку инициативы голосования по отзыву;

принятие комиссией по отзыву решения о соблюдении (несоблюдении) установленного порядка поддержки инициативы и передача документов в законодательный орган государственной власти субъекта Российской Федерации;

рассмотрение законодательным органом государственной власти субъекта Российской Федерации указанной инициативы и принятия им решения о назначении голосования по отзыву либо об отказе в назначении такого голосования;

опубликование решения о назначении голосовании по отзыву;

голосование по отзыву и подведение его итогов.

Процедура отзыва высшего должностного лица субъекта Российской Федерации предусматривает ряд процессуальных гарантий:

- она должна обеспечивать гражданам Российской Федерации, проживающим на территории субъекта Федерации и обладающим активным избирательным правом, возможность проведения агитации за его отзыв и против его отзыва, а также гарантировать участникам голосования всеобщее равное и прямое участие в тайном голосовании по отзыву;

- отзываемое лицо должно иметь возможность дать объяснения по поводу обстоятельств, выдвигаемых в качестве основания отзыва;

- на всех этапах осуществления отзыва отзываемым лицом может быть использовано право на защиту чести и достоинства, гражданских прав и свобод в суде.

Законом определены сроки осуществления соответствующих процедур по отзыву.

Как уже отмечалось, в случае предъявления обвинения высшему должностному лицу субъекта Российской Федерации в совершении преступления Президент Российской Федерации может своим указом 
временно отстранить высшее должностное лицо субъекта Российской Федерации от исполнения обязанностей.

При решении вопроса о применении Президентом Российской Федерации в отношении высшего должностного лица субъекта Российской Федерации такой меры, как временное отстранение от исполнения обязанностей, необходимо учитывать правовую позицию Конституционного Суда Российской Федерации, сформулированную в Постановлении по делу о проверке конституционности ряда положений Устава (Основного Закона) Алтайского края от 18 января 1996 года. В соответствии с данным Решением Конституционного Суда Российской Федерации нормы Устава Алтайского края, предусматривающие временное освобождение главы администрации края от должности до вынесения приговора по обвинению в совершении преступления, были признаны соответствующими Конституции Российской Федерации ${ }^{1}$. Примером использования Президентом Российской Федерации рассматриваемой меры может служить временное отстранение в марте 1996 г. главы администрации Саратовской области за «нецелевое использование финансовых средств».

Необходимо отметить, что практика реализации существующих антикоррупционных и конституционно-правовых антикриминальных механизмов свидетельствует об их недостаточной эффективности. Несмотря на принимаемые государством и общественностью меры по противодействию криминализации органов публичной власти, антикриминальная политика в Российской Федерации является несовершенной.

В действующем законодательстве присутствуют некоторые полумеры и антикоррупционные «послабления» в отношении ряда должностных лиц.

1 Постановление Конституционного Суда Российской Федерации по делу о проверке конституционности ряда положений Устава (Основного Закона) Алтайского края от 18 января 1996 года // Вестник Конституционного Суда Российской Федерации. 1996. № 1 . 
Во-первых, сведения о доходах, расходах, имуществе и обязательствах имущественного характера обязаны представлять не все чиновники, а только граждане, претендующие на замещение должностей гражданской и муниципальной службы, включенных в перечень, установленный нормативными правовыми актами Российской Федерации, а также гражданские и муниципальные служащие, замещающие должности из данного перечня.

Во-вторых, требования Федерального закона от 3 декабря 2012 г. № 230-Ф3 по расходам должностных лиц о каждой сделке, связанной с приобретением земельного участка, другого объекта недвижимости, транспортного средства, ценных бумаг, акций, долей участия, паев в уставных капиталах организаций, а также об источниках, за счет которых они были куплены, предполагают возможность неограниченного количества сделок и непредставления должностным лицом отчетности, если расходы превысят общий доход лица и его супруги (супруга) по основному месту их службы (работы) за три года, предшествующих сделке.

Во-третьих, антикоррупционные ограничения в отношении вкладов должностных лиц в иностранных банках и иностранных финансовых инструментов распространяются только на лиц, замещающих государственные должности Российской Федерации, должности федеральной государственной службы, назначение на которые и освобождение от которых осуществляются Президентом Российской Федерации, Правительством Российской Федерации, должности заместителей руководителей федеральных органов исполнительной власти, глав городских округов, глав муниципальных районов и ряд других должностей из соответствующего перечня. При этом установленные законом ограничения никак не затрагивают финансовой основы коррупционной деятельности возможности беспрепятственно выводить денежные средства за пределы территории Российской Федерации и вкладывать их в недвижимое имущество за рубежом. 
В-четвертых, антикоррупционные стандарты содержат различные подходы к оценке материального положения, источников доходов, законности и прозрачности расходов отдельных должностных лиц и правовым последствиям конфликта интересов у данных лиц, непредставления этими должностными лицами сведений о доходах, расходах, имуществе и обязательствах имущественного характера в установленные сроки, а также представления заведомо недостоверных или неполных сведений.

В-пятых, в соответствии с действующим законодательством возможно избрание в органы государственной власти и органы местного самоуправления лиц, находящихся в федеральном розыске, содержащихся под стражей, привлеченных в качестве обвиняемых по уголовным делам, неоднократно судимых, в том числе по тяжким составам преступлений. Для замещения депутатского мандата или выборной должности не является препятствием наличие у граждан уголовного прошлого и связей с организованной преступностью. Кандидаты в депутаты представительных органов муниципальных образований могут не представлять в избирательные комиссии сведения о размере и об источниках доходов, а также об имуществе на праве собственности, о вкладах в банках и ценных бумагах.

В связи с изложенным требуется изучение международно-правового регулирования и зарубежного опыта противодействия криминализации органов публичной власти с целью возможной последующей модернизации законодательства Российской Федерации. 


\section{5. МЕЖДУНАРОДНО-ПРАВОВЫЕ ОСНОВЫ И ЗАРУБЕЖНЫЙ ОПЫТ ПРОТИВОДЕЙСТВИЯ КРИМИНАЛИЗАЦИИ ОРГАНОВ ПУБЛИЧНОЙ ВЛАСТИ}

Основные направления противодействия криминализации органов публичной власти в Российской Федерации необходимо выстраивать с учетом существующих международно-правовых основ и зарубежного опыта. Государственная стратегия борьбы с организованной преступностью в органах публичной власти, как представляется, носит многоаспектный характер и в числе первоочередных мер предусматривает противодействие партийной и электоральной коррупции, обусловленной попытками криминалитета проникнуть в политические партии и органы власти.

Успешному внедрению криминалитета в политическую сферу во многом способствует коррупция в партийных структурах и государственном аппарате. Как справедливо отмечает Е.А. Мохов, «коррупция целенаправленно стимулируется и провоцируется организованной преступностью. .. Организованная преступность пытается фактически подменить собой систему государственных органов, а коррупция создает для этого необходимые предпосылки, ослабляя политическую волю государства, его способность реально влиять на процессы в обществе и экономике» ${ }^{1}$.

Учитывая криминологические взаимосвязи, схожую методологию уголовного расследования, судебного разбирательства, применения мер государственной защиты участников судопроизводства по делам о коррупции и организованной преступности, вопросы противодействия криминалитету в данном разделе рассматриваются в комплексе с вопросами противодействия коррупции в партийных структурах и органах публичной власти.

В связи с возросшими масштабами коррупционной пораженности государственного аппарата, значимостью антикриминальной политики,

${ }^{1}$ Мохов Е.A. Организованная преступность и национальная безопасность России. М.: Вузовская книга, 2006. С. 47. 
противодействие криминализации органов публичной власти, партийной и электоральной коррупции в современных условиях осуществляется не только на национальном, но и на международном уровне.

Первостепенное значение в структуре международно-правовых основ противодействия криминализации органов публичной власти, партийной и электоральной коррупции имеют универсальные акты ООН.

Антикриминальные и антикоррупционные стандарты ООН закреплены в Международном кодексе поведения государственных должностных лиц (Резолюция ГА ООН № 51/59 «Борьба с коррупцией» от 12 декабря 1996 года), Конвенции ООН против транснациональной организованной преступности (г. Палермо, 15 декабря 2000 года) и Конвенции ООН против коррупции (58 сессия ГА ООН, 21 ноября 2003 года).

В Международном кодексе поведения государственных должностных лиц сформулировано определение государственной должности, общие принципы осуществления официальных функций государственными должностными лицами, положение о недопустимости коллизии между обязанностями и частными интересами государственных должностных лиц, закреплены требования о сообщении государственными должностными лицами сведений о личных активах и обязательствах, а также об активах и обязательствах супруга (супруги) и иждивенцев.

В ст. 8 Конвенции ООН против транснациональной организованной преступности дан перечень уголовно-наказуемых форм коррупции, а в ст. 9 указаны меры выявления и предупреждения коррупции среди публичных должностных лиц и наказания за нее.

Приоритетное внимание уделено мерам государственной защиты свидетелей по делам, связанным с коррупцией и организованной преступностью. В соответствии со статьей 24 Конвенции ООН против транснациональной организованной преступности государства-участники должны принимать надлежащие меры для обеспечения эффективной защиты от мести или запугивания в отношении свидетелей, которые дают показания 
по делам, касающимся транснациональной организованной преступности. Предусматриваемые меры включают физическую защиту, переселение и полное или частичное неразглашение информации о личности и местонахождении свидетеля, a также принятие правил доказывания, позволяющих давать свидетельские показания таким образом, чтобы была обеспечена безопасность свидетеля.

Государства-участники Конвенции обязуются принимать такие законодательные и иные меры, которые могут потребоваться для того, чтобы наделить себя правом конфисковывать или иным образом изымать орудия совершения и доходы от уголовных правонарушений или имущество, стоимость которого эквивалентна таким доходам.

Важнейшим международным документом в сфере противодействия партийной и электоральной коррупции является Конвенция ООН против коррупции. В ст. 7 данного документа закреплена возможность государств устанавливать критерии к кандидатам и выборам на публичные должности, принимать законодательные и административные меры, чтобы усилить прозрачность в финансировании кандидатур на избираемые должности и финансировании политических партий.

В Конвенции также рассмотрены вопросы государственной защиты участников судопроизводства по делам о коррупции и организованной преступности. В статьях 32, 33 и 37 к государствам - участникам обращен призыв принимать надлежащие меры для защиты свидетелей от мести или запугивания в связи с дачей показаний. Согласно Конвенции защита должна предоставляться не только свидетелям, сотрудничающим со следствием, но и потерпевшим, которые стали свидетелями, и она может распространяться на родственников свидетелей и близких им лиц. Предусмотренные в Конвенции меры включают: установление процедур физической защиты, включая переселение в другое место и неразглашение информации о личности и местонахождении свидетеля; принятие правил доказывания, обеспечивающих безопасность свидетелей при даче показаний в суде; 
заключение между государствами-участниками соглашений, облегчающих процедуру переселения свидетелей за рубеж.

На региональном уровне существенный вклад в противодействие криминализации органов публичной власти, партийной и электоральной коррупции вносит Совет Европы.

Основополагающим документом, заложившим фундамент общеевропейского регулирования борьбы с коррупцией стала Резолюция Комитета Министров Совета Европы от 6 ноября 1997 года (1997) 24 «О двадцати Руководящих принципах борьбы с коррупцией» ${ }^{1}$. Руководящие принципы предполагали реализацию системы антикоррупционных мер, среди которых: разработка профилактических мер предотвращения коррупции; криминализация национальной и международной коррупции; установление ответственности должностных лиц за коррупционные деяния; обеспечение мер конфискации и лишения доходов от коррупции; ограничение иммунитетов от предварительного расследования и судебного преследования по делам о коррупции; проведение антикоррупционных расследований; принятие кодексов поведения выборных должностных лиц и антикоррупционных правил при финансировании политических партий и избирательных кампаний; специализация должностных лиц и органов, ответственных за борьбу с коррупцией; международное сотрудничество в борьбе с коррупцией.

Очередным шагом Совета Европы на пути борьбы с коррупцией явилась Резолюция Комитета Министров Совета Европы от 1 мая 1999 года (1999) 5 «О создании ГРЕКО». С ее принятием был создан не только механизм мониторинга соблюдения Руководящих принципов борьбы с коррупцией, но и контроля за выполнением международных договоров в сфере борьбы с коррупцией.

Ведущая роль Совета Европы в европейском антикоррупционном правотворчестве проявилась при разработке и принятии Конвенции Совета

\footnotetext{
${ }^{1}$ URL: //http://www.coe.int/t/dghl/monitoring/greco/documents/Resolution(97)24_EN.pdf
} 
Европы об уголовной ответственности за коррупцию (Страсбург, 27 января 1999 года) $^{1}$ и Конвенции Совета Европы о гражданско-правовой ответственности за коррупцию (Страсбург, 4 ноября 1999 года) $)^{2}$ В Втих международно-правовых договорах нашли отражение меры, принимаемые на национальном уровне, для установления уголовной и гражданско-правовой ответственности за коррупцию (создание специализированных органов по борьбе с коррупцией, санкции физическим и юридическим лицам, меры защиты свидетелей, содействия сбору доказательств и конфискации доходов, возмещение ущерба от коррупции, сроки исковой давности по возмещению ущерба и др.). Как отмечают О.И. Тиунов, А.А. Каширкина и А.Н. Морозов, «ратификация Российской Федерацией антикоррупционных конвенций повлекла за собой совершенствование целого ряда законодательных актов Российской Федерации, относящихся к таким отраслям законодательства, как конституционное, уголовное, административное, финансовое, трудовое и т.д. ${ }^{3} »$.

Договорная база Совета Европы в сфере противодействия криминализации органов публичной власти, партийной и электоральной коррупции тесно связана с кодексами поведения местных и региональных выборных представителей, а также государственных служащих. В развитие антикоррупционных положений Международного кодекса поведения государственных должностных лиц (Резолюция ГА ООН № 51/59 «Борьба с коррупцией» от 12 декабря 1996 года) Советом Европы 17 июня 1999 года и 11 мая 2000 года были приняты Европейский кодекс поведения для местных и региональных выборных представителей и Модельный кодекс поведения

1 Конвенции Совета Европы и Российской Федерации: Сб. док. М.: Юрид. лит., 2000. С. 281-289. Ратифицирована Федеральным законом от 25 июля 2006 года № 125-Ф3 «О ратификации Конвенции Совета Европы об уголовной ответственности за коррупцию». 4

${ }^{2}$ URL://http://conventions.coe.int/Treaty/Commun/QueVoulezVous.asp?CL=RUS\&NT=17

${ }^{3}$ Тиунов О.И., Каширкина А.А, Морозов А.Н. Влияние норм международного права на развитие национального законодательства // Журнал российского права. 2010. № 6. 
государственных служащих ${ }^{1}$. Согласно ст.13 Европейского кодекса поведения для местных и региональных выборных представителей выборные представители при вступлении в должность тщательно соблюдают любые требования законодательства в отношении обнародования источников и сумм доходов, которые были предназначены для финансирования избирательных кампаний, а также характера и сумм расходов. В Модельном кодексе поведения государственных служащих Совета Европы установлены антикоррупционные ограничения, обязанности и ответственность госслужащих.

Среди актов Совета Европы, посвященных противодействию криминализации органов публичной власти, партийной и электоральной коррупции, видное место занимают Рекомендация ПАСЕ 1516 (2001) «О финансировании политических партий» и Руководящие принципы финансирования политических партий Венецианской комиссии (2001).

В Рекомендации ПАСЕ 1516 (2001) закреплены правовые меры, направленные на предотвращение нарушений порядка финансирования избирательных кампаний и деятельности политических партий: запрет на пожертвования от государственных предприятий или организаций в сфере государственного управления; запрет на пожертвования от организаций, зарегистрированных в оффшорах; ограничения на пожертвования от юридических лиц; ограничения максимального размера пожертвования; запрет на пожертвования от религиозных организаций. При нарушении установленного порядка финансирования партии должны подвергаться санкциям, в том числе полной или частичной потере государственного финансирования, обязательному возмещению государственных расходов. В случае персональной ответственности санкции предполагают лишение избранного лица депутатского мандата или временную дисквалификацию².

\footnotetext{
${ }^{1}$ URL:// http://www.coe.int/t/dghl/monitoring/greco/documents/Rec(2000)10_EN.pdf

${ }^{2} \mathrm{URL}: / /$ http://assembly.coe.int/Mainf.asp?link=/Documents/AdoptedText/ta01/EREC1516.h tm (дата обращения: 20 марта 2012 г.)
} 
В соответствии с Руководящими принципами финансирования политических партий Венецианской комиссии (2001) (Страсбург, 9-10 марта 2001 г.) государственное финансирование должны получать все парламентские партии. Финансирование партий должно контролироваться специально уполномоченными государственными органами (например, Счетной палатой). В разделе «b» указаны возможные ограничения частного финансирования: максимальный размер пожертвования в избирательный фонд; запрет на прием пожертвований от промышленных предприятий, коммерческих и религиозных организаций; первостепенный контроль пожертвований членов партии, баллотирующихся на выборах. Каждая партия должна публиковать ежегодный финансовый отчет за предыдущий год, который должен содержать перечень всех пожертвований, кроме членских взносов ${ }^{1}$.

В отличие от Рекомендации ПАСЕ 1516 (2001), Руководящие принципы финансирования политических партий Венецианской комиссии (2001) в качестве санкций за нарушения порядка финансирования избирательных кампаний и деятельности политических партий наряду с возможностью полной или частичной потери государственного финансирования на следующий год предусматривают отмену результатов выборов. В то же время в данном документе отсутствует прямое упоминание об обязательном возмещении государственных расходов на финансирование избирательной кампании.

Специализированным нормативным правовым актом в сфере противодействия криминализации органов публичной власти, партийной и электоральной коррупции стали принятые 8 апреля 2003 года Комитетом Министров Совета Европы Рекомендации «Об общих принципах борьбы с коррупцией при финансировании политических партий и избирательных кампаний».

\footnotetext{
${ }^{1}$ URL: // http://www.venice.coe.int/docs/2001/CDL-INF(2001)008-e.pdf (дата обращения: 20 марта 2012 г.)
} 
В соответствии со ст. 9 указанных Рекомендаций государства должны предотвращать чрезмерные финансовые расходы политических партий и устанавливать общий размер расходов на ведение избирательной кампании. «Хотя юридическое обеспечение и должно разрешать избирающимся претендентам расходовать достаточные ресурсы, чтобы довести свои политические идеи до избирателей, нет никаких минимальных стандартов, которые предполагали бы возможность «купить» выборы» ${ }^{1}$.

Каждая политическая партия и каждый кандидат должны вести отчетность по всем расходам на избирательную кампанию. В отчетах политических партий должны быть сведения о всех пожертвованиях, полученных партией, включая вид и объем пожертвования (статьи 10 и 12 Рекомендации Rec (2003) 4 Комитета Министров Совета Европы) ${ }^{2}$.

В статье 14 Рекомендации Rec (2003) 4 Комитета Министров Совета Европы закрепляется необходимость государства обеспечить независимый мониторинг финансирования политических партий и избирательных кампаний.

В целях борьбы с коррупцией в избирательном процессе статья 15 Рекомендации Rec (2003) 4 Комитета Министров Совета Европы содержит обязанность государств-участников Совета Европы осуществлять подготовку и «поддерживать специализацию судебного, милицейского и иного персонала на борьбе против незаконного финансирования политических партий и избирательных кампаний» ${ }^{3}$.

Следующим элементом структуры международно-правовых основ противодействия криминализации органов публичной власти, партийной и электоральной коррупции являются акты ОБСЕ.

${ }^{1}$ Международные избирательные стандарты. Сб. документов // Отв. ред.: кандидат юрид. наук А.А. Вешняков; науч. ред.: доктор юрид. наук В.И. Лысенко. М.: Издательство Весь Мир, 2004. С. 451.

2 Международные избирательные стандарты. Сб. документов // Отв. ред. доктор юрид. наук В.И. Лысенко. М.: ЦИК России, 2009. С. 382-383.

3 Международные избирательные стандарты. Сб. документов // Отв. ред. доктор юрид. наук В.И. Лысенко. М.: ЦИК России, 2009. С. 383. 
Хартия европейской безопасности ОБСЕ (Стамбул, 19 ноября 1999 года) закрепила обязательства государств-участников вести борьбу с коррупцией во всех измерениях ОБСЕ. В Бухарестской декларации Парламентской Ассамблеи ОБСЕ (Бухарест, 10 июля 2000 года) сформулировано требование принять законы, запрещающие тайное финансирование политических партий и кандидатов.

При подписании Парижской декларации Парламентской Ассамблеи ОБСЕ (Париж, 10 июля 2001 года) была принята Резолюция «О борьбе с коррупцией и международной преступностью в регионе ОБСЕ». В Резолюции содержится призыв: к поощрению обнародования государственными официальными лицами, политическими партиями и кандидатами на выборные должности сведений о своем финансовом положении; к содействию в проведении свободных и честных общенациональных, региональных и местных выборов, предоставлению общественности доступа к информации о деятельности государственных учреждений, а также взаимодействию с институтами гражданского общества в борьбе с коррупцией; к принятию решительных мер для проведения в зонах конфликтов свободных и равноправных выборов при необходимом условии участия в выборах всего населения, проживавшего в этих местах до конфликта, как предпосылки для борьбы с коррупцией и организованной преступностью; к возможной ратификации и применению существующих международных соглашений по вопросам борьбы с коррупцией.

В части финансирования политических партий и избирательных кампаний необходимо обратить внимание на Рекомендации БДИПЧ/ОБСЕ по анализу законодательной базы выборов (Варшава, январь 2001 года) и Обязательства по проведению демократических выборов в государствахучастниках ОБСЕ (Варшава, 30 июня 2003 года).

В соответствии с Рекомендациями БДИПЧ/ОБСЕ государственное финансирование предоставляется политическим партиям и кандидатам на основе их равенства перед законом. Эксперты ОБСЕ считают несовершенной 
законодательную базу, которая предусматривает исключительно государственное финансирование избирательной кампании. Любые запреты или ограничения частного финансирования могут являться нарушением права личности на свободу ассоциаций и свободу выражения.

Данное положение Рекомендаций, рассматривающее любые ограничения частного финансирования как ущемление прав личности, противоречит другой части Рекомендаций, в которой признается допустимость разумных ограничений размера частных пожертвований и общего размера расходов кандидатов ${ }^{1}$.

В Обязательствах по проведению демократических выборов в государствах-участниках ОБСЕ 2003 года, в отличие от Рекомендаций БДИПЧ/ОБСЕ 2001 года позиция ОБСЕ об ограничениях частного финансирования смягчена. В пункте В раздела VII указано, что «государства могут устанавливать разумные ограничения на объемы частного финансирования политических партий и кандидатов, чтобы обеспечить честное соревнование в ходе выборов и понизить стимулы для коррупции и оказания излишнего влияния на политику». В Обязательствах расширен перечень недопустимых источников финансирования политических партий и кандидатов: государства могут запрещать или ограничивать оказание финансовой или иной материальной и другой поддержки политическим партиям и кандидатам от иностранных граждан и организаций, государственных органов и государственных предприятий.

Самостоятельный блок международно-правовых основ противодействия криминализации органов публичной власти, партийной и электоральной коррупции в формате СНГ образуют акты Содружества.

В состав правовой базы государств-участников СНГ в сфере противодействия криминализации органов публичной власти, партийной и

${ }^{1}$ Раздел Х Рекомендаций БДИПЧ/ОБСЕ по анализу законодательной базы выборов / Международные избирательные стандарты. Сб. документов // Отв. ред. доктор юрид. наук В.И. Лысенко. М.: ЦИК России, 2009. С. 230-232. 
электоральной коррупции входят как нормативные договоры обязывающего характера, так и рекомендательные международные правовые акты.

В 2001 году Российская Федерация выступила с инициативой разработки Конвенции о стандартах демократических выборов, избирательных прав и свобод в государствах - участниках СНГ (далее Конвенции), подписанной 7 октября 2002 года в Кишиневе президентами Армении, Грузии, Кыргызстана, Молдовы, России, Таджикистана и Украины и вступившей в силу 11 ноября 2003 года. Этот документ имеет обязательный характер для участников Конвенции. В Конвенции даны стандарты демократических выборов и механизмы их реализации, закреплены положения, связанные с финансированием и информационной поддержкой выборов. Согласно ст. 12 Конвенции запрещаются иностранные пожертвования кандидатам, политическим партиям, участвующим в выборах, общественным объединениям, которые находятся под влиянием кандидатов (политических партий) либо содействуют реализации их целей. Кандидаты и политические партии должны с установленной периодичностью представлять в избирательные органы сведения и отчеты о поступлении пожертвований в избирательные фонды, о вкладчиках, а также о всех расходах из этих фондов на финансирование избирательной кампании.

Среди актов Содружества выделяется группа модельных законов в сфере противодействия коррупции (в том числе партийной и электоральной).

В соответствии с ч. 1 ст. 8 Модельного закона СНГ от 25 ноября 2008 года «О противодействии коррупции», ч. 1 ст. 5 Модельного закона СНГ от 15 ноября 2003 года «Основы законодательства об антикоррупционной политике», реализация избирательных прав и деятельность политических партий относятся к числу приоритетных направлений правового регулирования в сфере противодействия коррупции.

Модельное законотворчество государств-участников СНГ в сфере противодействия коррупции является одной из форм правовой интеграции в формате Содружества. Согласно пп. «в», «г» ст. 4 Конвенции о 
Межпарламентской Ассамблеи государств-участников СНГ от 26 мая 1995 г., ст. 15 Регламента Межпарламентской Ассамблеи государств-участников СНГ (принят 15 сентября 1992 г., дополнен 18 марта 1994 г.), пп. 1.2 и 1.4 Положения о разработке модельных законодательных актов и Рекомендаций Межпарламентской Ассамблеи государств-участников СНГ (принято 14 апреля 2005 г., дополнено 25 ноября 2008 г.) модельные законы являются международными правовыми актами рекомендательного характера. Они принимаются Межпарламентской Ассамблеей для ориентации согласованной законодательной деятельности и сближения законодательства государствучастников Содружества.

Наличие ориентирующих норм, регулирующих финансирование избирательных кампаний на пространстве СНГ, крайне важно для борьбы государств-участников Содружества с партийной и электоральной коррупцией, легализацией денежных средств в условиях выборов, обеспечения целевого характера финансирования субъектов избирательного процесса и их публичной отчетности.

В Модельном законе СНГ «Основы законодательства об антикоррупционной политике» в качестве одной из задач антикоррупционной политики предусмотрено создание правового механизма, препятствующего подкупу граждан при проведении выборов и референдума. Элементами подобного механизма являются установление ответственности за электоральные правонарушения и преступления, а также разработка антикоррупционных и антикриминальных стандартов в сфере реализации избирательных прав и деятельности политических партий.

На основании ч. 4 ст. 8 Основ законодательства об антикоррупционной политике, к административным коррупционным правонарушениям электоральной направленности отнесены: вмешательство в работу избирательной комиссии; подкуп избирателей; непредоставление или неопубликование отчета, сведений о поступлении и расходовании средств на подготовку и проведение выборов; незаконное использование денежных 
средств кандидатом, зарегистрированным кандидатом, избирательным объединением, избирательным блоком, инициативной группой по проведению референдума; использование незаконной материальной поддержки кандидатом, зарегистрированным кандидатом, избирательным объединением, избирательным блоком, инициативной группой по проведению референдума; финансирование избирательной кампании помимо избирательных фондов и оказание иной запрещенной законом материальной поддержки; нецелевое использование бюджетных средств.

Перечень указанных в Основах законодательства составов административных правонарушений электоральной направленности представляется целесообразным дополнить за счет включения следующих противоправных деяний: «осуществление в период избирательной кампании рекламы и (или) благотворительной деятельности с нарушением законодательства о выборах и референдумах», «нарушение запрета на проведение в период избирательной кампании, кампании референдума лотерей и других основанных на риске игр, связанных с выборами и референдумами», «получение избирателем (участником референдума) выгоды материального и (или) нематериального характера за осуществление волеизъявления» .

В соответствии с ч.5 ст.8 к коррупционным преступлениям электоральной направленности в форме подкупа относятся воспрепятствование осуществлению избирательных прав или работе избирательных комиссий, запрещенные под угрозой наказания Уголовным кодексом, в случае совершения соответствующего деяния путем подкупа. На взгляд автора, эффективность законодательного противодействия коррупции в избирательном процессе можно было бы повысить путем введения в Основы законодательства об антикоррупционной политике уголовной ответственности за фальсификацию избирательных документов (документов референдума), связанную с подкупом. 
Правовые запреты, сформулированные в диспозициях административно-правовых и уголовно-правовых норм, дополняются системой антикоррупционных и антикриминальных стандартов в сфере реализации избирательных прав и деятельности политических партий.

Антикоррупционные стандарты представлены едиными гарантиями, ограничениями и запретами, обеспечивающими уменьшение воздействия коррупции на функционирование данной сферы. Система антикоррупционных и антикриминальных стандартов в сфере реализации избирательных прав и деятельности политических партий закреплена в ст.18 Основ законодательства об антикоррупционной политике.

В целях противодействия криминализации органов публичной власти, партийной и электоральной коррупции при проведении выборов на должности органов государственной власти и местного самоуправления национальным законодательством устанавливаются:

1) гарантии на: равное участие в составе избирательных комиссий представителей кандидатов на соответствующие должности с момента выдвижения таких кандидатов; возврат в бюджет кандидатами, не избранными на соответствующие должности, денежных средств, выделенных на проведение избирательной кампании;

2) запреть на: предоставление кандидатами или от их имени имущества, прав на него, услуг или льгот имущественного характера избирателям; использование кандидатами финансовой и иной поддержки юридических и физических лиц за исключением случаев, предусмотренных законодательством; использование в случаях и порядке, прямо предусмотренных законодательством, во время избирательной кампании кандидатами на соответствующие должности своего публичного статуса и связанных с ним возможностей для достижения целей избирательной кампании; отнесение к конфиденциальной информации данных об имуществе, обязательствах имущественного характера, доходах и расходах кандидатов, их супругов и близких родственников; участие в составе 
избирательных комиссий (комиссий референдума) лиц, имеющих или когдалибо имевших судимость за коррупционные преступления, либо подвергавшихся административным или дисциплинарным взысканиям за совершение коррупционных правонарушений; регистрацию в качестве кандидатов на соответствующие должности лиц, имеющих или когда-либо имевших судимость за коррупционные преступления.

Как мы видим, данная система антикоррупционных и антикриминальных стандартов выстроена по модели «гарантии - запреты». Третий элемент антикоррупционных и антикриминальных стандартов в сфере реализации избирательных прав и деятельности партий при проведении выборов - «ограничения» - предусмотрен в Модельном законе «О противодействии коррупции».

Согласно ст.12 Модельного закона «О противодействии коррупции» для лиц, претендующих на занятие должностей депутатов законодательных органов власти, органов местного самоуправления, а также лиц, занимающих указанные должности, могут устанавливаться определенные ограничения и запреты, связанные с выполнением ими своих служебных обязанностей. При этом они должны ставиться в известность о необходимости соблюдения этих ограничений и запретов, а также о мерах ответственности в случае их невыполнения.

Пропорциональность, допустимость и правомерность установления государствами ряда ограничений пассивного избирательного права граждан неоднократно рассматривалась в прецедентной практике Европейского Суда по правам человека.

Статья 25 Международного пакта о гражданских и политических правах допускает введение обоснованных ограничений права и возможности каждого гражданина быть избранным на периодических выборах, производимых на основе всеобщего равного избирательного права при тайном голосовании и обеспечивающих свободное волеизъявление избирателей. Как отмечается в постановлениях Европейского Суда по 
правам человека по делам «Матье-Моэн и Клерфейт против Бельгии», «Дойл против Соединенного Королевства», право лица выдвигать свою кандидатуру на выборах не носит абсолютного характера ${ }^{1}$. Поскольку статья 3 Протокола № 1 к Конвенции о защите прав человека и основных свобод, признавая это право, не конкретизирует его и тем более не дает ему юридического определения, появляются возможности для введения так называемых имплицитных или подразумеваемых ограничений (постановление по делу «Матье-Моэн (Mathieu-Mohin) и Клерфейт (Clerfayt) против Бельгии»); государства достаточно свободны в рамках своего конституционного строя устанавливать статус парламентариев, включая критерии избираемости (постановление по делу «Гитонас (Gitonas) и другие против Греции», «Подколзина против Латвии», «Дойл против Соединенного Королевства»). Эти критерии различаются в зависимости от исторических и политических особенностей каждого государства.

Легальная конструкция антикоррупционных и антикриминальных стандартов в сфере реализации избирательных прав и деятельности политических партий предполагает выделение двух фрагментов: а) стандартов, касающихся правового статуса субъектов избирательного процесса (в первую очередь, организаторов выборов и кандидатов); б) стандартов финансирования избирательной кампании.

В Модельном законе определены условия несовместимости статуса членов избирательных комиссий и зарегистрированных кандидатов. Лица, имеющие или когда-либо имевшие судимость за коррупционные преступления, а также за преступления, связанные с коррупционными, не могут быть членами избирательных комиссий и зарегистрированными кандидатами на выборные должности в органах власти. Кандидаты не могут использовать свой публичный статус (т.н. «административный ресурс») для

\footnotetext{
${ }^{1}$ Решение Европейского Суда по правам человека от 2 марта 1987 г. по делу «Матье-Моэн (Mathieu-Mohin) и Клерфейт (Clerfayt) против Бельгии» // Европейский Суд по правам человека. Избранные решения: в 2 т. М.: Норма, 2000; Решение Европейского Суда по правам человека от 6 февраля 2007 г. по делу «Дойл (Doyle) против Соединенного Королевства» // Бюллетень Европейского Суда по правам человека. Российское издание. 2007. № 8 .
} 
достижения целей избирательной кампании. Данная группа стандартов касается правового статуса субъектов избирательного процесса.

Вторая группа антикоррупционных стандартов связана с финансированием избирательной кампании. Сюда следует отнести: возврат неизбранными кандидатами бюджетных средств, выделенных на проведение избирательной кампании; запрет на предоставление кандидатами или от их имени имущества, прав на него, услуг или льгот имущественного характера избирателям; запрет на использование кандидатами финансовой и иной поддержки юридических и физических лиц, прямо не предусмотренной законодательством; запрет на отнесение к конфиденциальной информации данных об имуществе, обязательствах имущественного характера, доходах и расходах кандидатов на замещение соответствующих должностей в органах власти, их супругов и близких родственников.

Рассмотрев систему международных актов в сфере противодействия криминализации органов публичной власти, партийной и электоральной коррупции, следует уделить внимание тенденциям и перспективам развития международных антикоррупционных правовых основ в данной сфере.

Исходя из разработанности массива антикоррупционных (антикриминальных) международных актов и содержания правовых мер противодействия коррупции, можно выделить несколько основных этапов эволюции международно-правовых основ противодействия коррупции (в том числе, партийной и электоральной):

1. Конец 70-х гг. XX в. - начало 90-х гг. XX в.

2. Середина 90-х гг. ХХ в. - конец 90-х гг. ХХ в.

3. Начало XXI в. - н.в.

В рамках первого этапа (конец 70-х гг. ХХ в. - начало 90-х гг. ХХ в.) Организацией Объединенных Наций были предприняты попытки сформулировать определение коррупции, а также закрепить позицию мирового сообщества и международных организаций по отношению к коррупционным деяниям. 
На втором этапе (середина 90-х гг. XX в. - конец 90-х гг. XX в.) Советом Европы была создана общеевропейская правовая система противодействия коррупции, установлены приоритетные сферы предупреждения коррупции, разработаны программы борьбы с коррупцией и учреждена специализированная антикоррупционная организация ГРЕКО. В Хартии европейской безопасности ОБСЕ были закреплены обязательства государств-участников вести борьбу с коррупцией во всех измерениях ОБСЕ.

Tретий этап (начало XXI в. - н.в.) связан с присоединением большинства государств СНГ к ГРЕКО, участием государств Содружества в формировании международной антикоррупционной (антикриминальной) правовой базы и разработкой специализированных актов Совета Европы и СНГ по противодействию партийной и электоральной коррупции.

В этот период международные соглашения Совета Европы о противодействии криминализации органов публичной власти и коррупции были дополнены модельным кодексом поведения государственных служащих, специализированными рекомендациями о финансировании политических партий, об общих принципах борьбы с коррупцией при финансировании политических партий и избирательных кампаний, мерами государственной защиты свидетелей и иных участников судопроизводства по делам, связанным с коррупцией и организованной преступностью. По инициативе России некоторыми государствами-участниками СНГ был подписан и ратифицирован первый юридически-обязывающий международный документ, закрепивший комплекс стандартов демократических выборов (в том числе вопросы финансирования выборов, избирательных кампаний политических партий и кандидатов) - Конвенция о стандартах демократических выборов, избирательных прав и свобод в государствах - участниках СНГ. МПА СНГ были приняты Основы законодательства об антикоррупционной политике и Модельный закон «О противодействии коррупции», содержащие антикоррупционные и 
антикриминальные стандарты в сфере реализации избирательных прав и деятельности политических партий.

В качестве перспективных направлений эволюции международноправовых основ противодействия криминализации органов публичной власти, партийной и электоральной коррупции на пространстве СНГ можно выделить: дальнейшую ратификацию конвенционных соглашений в сфере противодействия коррупции; международное регулирование порядка финансирования использования информационных технологий в избирательном процессе, регламентацию расходов на предвыборную агитацию в сети Интернет; заключение соглашений о правовой помощи по уголовным и гражданским делам о коррупционных правонарушениях и организованной преступности; правовое регулирование двусторонних и многосторонних антикоррупционных (антикриминальных) расследований; приведение законодательства государств - участников СНГ о выборах и политических партиях в соответствие с антикоррупционными (антикриминальными) стандартами модельных законов Межпарламентской Ассамблеи СНГ.

Проведя анализ международно-правовой базы, остановимся на зарубежном опыте противодействия криминализации органов публичной власти. Как и в Российской Федерации, антикриминальная политика большинства зарубежных стран осуществляется в условиях избирательного процесса и при назначении претендентов на должности.

В рамках избирательного процесса на этапе составления списков избирателей, а также при выдвижении и регистрации кандидатов на выборные должности в зарубежных странах в интересах противодействия криминализации органов власти, партийной и электоральной коррупции активно используется лишение избирательного права отдельных категорий граждан ${ }^{1}$.

1 Игнатов А.В. Ограничения всеобщего избирательного права в отношении права быть избранным в национальные парламенты государств-участников СНГ / Научные 
В теории избирательного права и конституционно-правовой практике «лишение избирательного права» следует рассматривать как меру предупреждения девиантного поведения граждан или меру наказания, применяемую к правонарушителям.

Лишение избирательного права заключается во временной или бессрочной утрате субъектом права субъективного избирательного права, являющейся мерой превентивного или карательного характера. Лишение избирательного права может быть связано как с правомерным (недееспособность), так и с противоправным поведением субъектов права. Лишение избирательного права кроме ограничения правосубъектности недееспособных лиц означает основное или дополнительное уголовное наказание, которое закреплено в санкции нормы права, носит личный характер и назначается судом с учетом общественной опасности правонарушения. Во многих зарубежных странах лица, отбывающие наказание в местах лишения свободы по приговору суда ограничены в избирательном праве или лишены его1. В Австрии, Бельгии, Франции, Германии, Греции, Италии, Люксембурге, Мальте, Нидерландах, Норвегии, Польше, Румынии и Турции существуют ограничения избирательного права заключенных. В Армении, Азербайджане, Болгарии, Эстонии, Грузии, Ирландии, Латвии, Лихтенштейне, Молдавии, Российской Федерации, Словакии и Великобритании заключенные лишены права голоса.

труды РАЮН. Вып. 9. Т.1. М.: Юрист, 2009. С. 965-969; Куракина С.И, Цыбисова А.С. Ограничения в избирательном праве: международная практика / IV Державинские чтения в Республике Мордовия. Материалы науч.-практ. конф. Саранск, 2008. С. 199-200; Сафаров P.A. Проблема неправомерного ограничения избирательных прав граждан в зарубежных странах / Проблемы защиты прав: история и современность. Материалы Международной науч.-практ. конф. СПб, 2007. С. 88-93; Страшун Б.А. Избирательное право социалистических государств. М.: ИМО, 1963. С. 41, 42, 44-84, 87-93.

Дуксин П.А. Лишение избирательных прав лиц, признанных судом недееспособными, и лиц, содержащихся в местах лишения свободы по приговору суда: справедливость и целесообразность / Сборник конкурсных работ в области избирательного права, избирательного процесса и законодательства о референдуме, выполненных студентами и аспирантами высших юридических учебных заведений Российской Федерации в 2004-2005 году. М.: РЦОИТ, 2005. С. 125-138. 
В этой связи представляет интерес практика Европейского Суда по правам человека, связанная с защитой избирательного права осужденных лиц. 6 октября 2005 г. Большая палата Европейского Суда по правам человека вынесла окончательное решение по делу «Хирст против Соединенного Королевства» (Hirst v. United Kingdom) (жалоба № 74025/01)1. Заявитель, Джон Хирст, приговоренный к пожизненному лишению свободы за убийство, обжаловал положения ст. 3 Акта о народном представительстве 1983 г. о запрете принимать участие в голосовании на выборах в Парламент или местные органы власти. Европейский Суд признал несоответствие ст.3 Закона о народном представительстве Протоколу № 1 Конвенции о защите прав человека. По мнению Суда, запрет на участие заключенных в выборах не должен распространяться на всех осужденных, кроме того, данное ограничение должно применяться в зависимости от срока назначенного наказания и тяжести правонарушения. Европейский Суд предоставил Великобритании право самостоятельно избрать способ обеспечения избирательных прав заключенных².

Конституционно значимыми целями лишения избирательного права являются: поддержание авторитета закона, исключение возможности криминального влияния на формирование органов народного представительства, недопущение правонарушителей в выборные органы власти. В отличие от ограничения избирательного права, лишение избирательного права в зарубежных странах может носить как устранимый (истечение срока наказания, помилование, амнистия), так и неустранимый характер (пожизненное тюремное заключение с бессрочным лишением, недееспособность вследствие неизлечимого психического заболевания).

${ }^{1}$ Постановление Европейского Суда по правам человека от 6 октября 2005 г. по делу «Хирст против Соединенного Королевства» (Hirst v. United Kingdom) (жалоба № 74025/01) // Бюллетень Европейского Суда по правам человека. Российское издание. 2006, № 4.

2 В государствах, где заключенные имеют право голоса (Албания, Босния и Герцеговина, Кипр, Хорватия, Чехия, Дания, Финляндия, бывшая югославская республика Македония, Исландия, Литва, Португалия, Словения, Испания, Швеция, Швейцария и Украина), она реализуют свое избирательное право путем голосования по почте, по доверенности и другими предусмотренными законом способами. 
Конкретные основания, сфера и продолжительность действия, механизм реализации лишения избирательного права устанавливаются конституционным, выборным и уголовным законодательством.

По времени действия различают пожизненное лишение избирательного права и лишение избирательного права на определенный срок. Согласно статьям L 5-8 Избирательного кодекса Франции лица, осужденные за преступления, лишаются избирательных прав пожизненно. В отношении осужденных за проступки в сфере избирательного права лишение избирательного права может носить временный характер ${ }^{1}$.

В соответствии с § 45 УК ФРГ лишение пассивного избирательного права осуществляется на срок от 2 до 5 лет. § 22 разд. 2 Положения о порядке проведения выборов в Национальный Совет Австрии (Nationalratswahlordnung 1992) предусматривает лишение осужденных избирательного права на 6 месяцев $^{2}$. В Китае политических (в том числе и избирательных) прав пожизненно лишаются лица, совершившие контрреволюционные преступления, а также осужденные к смертной казни и бессрочному лишению свободы ${ }^{3}$.

По сфере действия лишение избирательного права может распространяться на выборы в конкретном избирательном округе (локальное лишение) или на все виды выборов на всей территории государства (универсальное лишение права). Лицо, совершившее коррупционное правонарушение в сфере избирательного права Великобритании (мошенничество, неправомерное давление на избирателей, превышение предельных размеров предвыборных расходов, подкуп, фальсификацию документов о выдвижении кандидата), лишается пассивного избирательного права на 10 лет на территории всей страны. За осуществление незаконной практики (нарушение различных законодательных требований о доверенных

\footnotetext{
${ }^{1}$ Избирательный кодекс Франции // Journal Officiel de la Republique Franзaise, 26 janvier 1985. № 21 .

${ }^{2}$ Bundesgesetz BGB1. Nr. 47/ 1992; BGB1. I Nr. 28/2007.

3 Зарубежное избирательное право: Учебное пособие. М.: Норма, 2003. С. 168.
} 
лицах, использования помещений, рекламы, освещения предвыборной кампании, голосование более одного раза, голосование, несмотря на лишение права голоса и др.) к правонарушителю применяется лишение пассивного избирательного права на 5 лет на территории конкретного избирательного округа ${ }^{1}$.

По содержанию изъятий объема правосубъектности лишение избирательного права делится на лишение активного избирательного права и лишение пассивного избирательного права. Решением Государственного трибунала Польской Республики лицо, совершившее преступление, связанное с нарушением Конституции или законов, может быть лишено как активного, так и пассивного избирательного права на всех видах выборов (п.1 ст. 23 Закона «О государственном трибунале» от 26 марта 1982 г.) $)^{2}$ В Канаде пассивного избирательного права лишены лица, отбывающие наказание в местах лишения свободы на срок свыше двух лет ${ }^{3}$.

По свободе усмотрения правоприменителя необходимо различать императивное и дискреционное лишение избирательного права. В случае императивного лишения избирательного права все основания лишения субъективного права четко предусмотрены действующим законодательством, и правоприменитель обязан ими руководствоваться (Мексика) ${ }^{4}$. Дискреционное лишение избирательного права осуществляется по усмотрению суда с учетом общественной опасности правонарушения, личности правонарушителя и других юридически значимых обстоятельств $(\text { Франция })^{5}$.

${ }^{1}$ В соответствии с Актом о народном представительстве 1983 г. (the Representation of the People Act 1983) в избирательном праве Великобритании все правонарушения подразделяются на 2 вида - на коррупцию и незаконную практику (corrupt or illegal practices), что влечет для правонарушителя ограничение пассивного избирательного права. Аналогичная классификация правонарушений в сфере избирательного права принята и в Канаде. См. Зарубежное избирательное право: Учебное пособие. М.: Норма, 2003. С. 86.

${ }^{2}$ Современные избирательные системы. Вып. 1: Великобритания, Канада, Мексика, Польша. М.: Норма, 2006. С. 370.

${ }^{3}$ Там же. С. 207.

${ }^{4}$ Современные избирательные системы. Вып. 1: Великобритания, Канада, Мексика, Польша. М.: Норма, 2006. С. 292.

5 Зарубежное избирательное право: Учебное пособие. М.: Норма, 2003. С. 93. 
К числу особых видов лишения избирательного права в зарубежных странах можно отнести: приостановление избирательного права (Мексика); запрет регистрации в качестве кандидата от определенной политической партии (Мексика); объявление неизбираемости на определенный срок (Франция). Особые виды лишения избирательного права имеют ряд общих черт, определяющих их правовую природу: устранимость (субъект права сохраняет возможность восстановления избирательного права), превентивный или карательный характер (карательные элементы лишения права направлены на прекращение субъектом права антиобщественного или противоправного поведения).

Современная штрафная политика большинства зарубежных стран сочетает ориентацию на предупреждение девиантного и противоправного поведения граждан; экономию репрессивных мер, применяемых к правонарушителям, подвергнутым лишению избирательного права; рациональное дополнение различных видов наказаний, учитывающее степень общественной опасности допущенных нарушений закона.

Изучив основные «антикриминальные» (антикоррупционные) меры в избирательном процессе, рассмотрим зарубежный опыт противодействия криминализации органов публичной власти в формате правотворческой и правоприменительной деятельности государства.

Отдельного внимания заслуживает «антикриминальный» опыт США в начале 30-х и в 60-х годах XX в.

В 30-х гг. на фоне «сухого закона» в ряде крупнейших городов США (наиболее яркий пример - Чикаго) стремительно выросло количество преступных группировок. Ответом на эту криминальную волну стало создание в США двух специальных органов по борьбе с организованной преступностью - так называемого «Бюро по табаку, алкоголю и огнестрельному оружию» при министерстве финансов и «Бюро расследований» при ведомстве Генерального прокурора (позднее - ФБР). В эти органы, которые получили очень большие полномочия, набирались 
наиболее квалифицированные специалисты по борьбе с криминалом, причем все они проходили жесткий отбор по личным качествам, исключавший попадание в них случайных или тем более криминализованных фигур. И уже через два-три года большинство преступных группировок в стране были если не разгромлены, то резко подавлены. При этом главным оружием в борьбе с организованной преступностью стали законодательные меры, обеспечивавшие «антикоррупционное» и «антикриминальное» наполнение органов власти и правоохранительных органов. Так, в США в системе полиции не только были созданы специальные подразделения внутренней безопасности. Помимо этого, ФБР получило право и обязанность контроля за назначениями на «чувствительные» должности в правоохранительной системе. И, главное, - через ФБР был усилен федеральный контроль над всеми местными правоохранительными органами.

Кроме того, было принято законодательство, которое требует обязательной проверки ФБР всех лиц, поступающих на государственную службу. И эта проверка вовсе не формальная. Проверяется биография и послужной список человека, проверяются его семейные и при необходимости дружеские связи, проверяется он сам на полиграфе. И не то что криминальные события в его прошлом, но даже не слишком обоснованные подозрения о наличии такого рода событий являются непреодолимым препятствием для продвижения даже на низовые, местные уровни государственной власти.

Эта практика уже много лет является предметом критики со стороны американских правозащитников. Однако американское общество ее в целом поддерживает, считая, что такое ущемление прав соискателей государственной службы есть допустимая и оправданная плата за некоррумпированные и некриминальные органы власти ${ }^{1}$.

В 60-х годах XX в. Америка столкнулась с новой, еще более мощной по масштабам волной организованной преступности, которая начала

\footnotetext{
${ }^{1}$ Зорькин В. Конституция против криминала // Рос. газ. 2010. 10 декабря.
} 
приобретать все более отчетливый транснациональный характер, а также активно вторгаться в сферы деятельности легального бизнеса. Попытка ответить на этот вызов принятием отдельных законов по конкретным составам преступлений организованных преступных групп давала половинчатые результаты. И тогда, после длительного обсуждения в юридической и политической среде, конгресс США принял так называемый «акт RICO» (the Racketeer Influenced and Corrupt Organizations Act) 1970 года, который очень существенно расширил сферу подсудности преступных сообществ (организаций), включив в нее не только рэкет и коррупцию, но и несколько десятков других составов «оргпреступных» деяний. Кроме того, акт RICO очень существенно ужесточил наказания за преступления, совершенные в составе организованных преступных групп.

Конгресс сформулировал цель закона следующим образом: «Наряду с привлечением к ответственности физических лиц, основная цель закона RICO - уничтожение криминальной организации как таковой». Основными правовыми инструментами для этого стали институт конфискации и ответственности юридических лиц.

В результате применения акта RICO большинство уголовных дел в отношении преступных сообществ, возбуждаемых прокурорами, завершалось осуждением виновных, а организованная преступность в США существенно снизилась ${ }^{1}$.

В акт RICO 1970 г. также были включены процессуальные меры безопасности потерпевших и свидетелей. Согласно акту RICO министр юстиции США уполномочен обеспечивать безопасность свидетелей, согласившихся дать правдивые показания по делам, касающимся организованной преступности и иных серьезных преступлений. Находящаяся в ведении министра юстиции США Федеральная программа по обеспечению безопасности свидетелей (ВИТСЕК) предусматривает защиту подвергающихся угрозе свидетелей от физической опасности, в основном, 
путем их переселения на новое, неразглашаемое место жительства с изменением имени и других личных данных ${ }^{1}$.

Успешным является японский опыт борьбы с организованной преступностью и противодействия криминализации органов власти.

Так, в 80-х гг. японскими специалистами были выделены следующие стратегические направления в борьбе с конкретными преступными сообществами ${ }^{2}$ :

- нарушение организационных структур преступных группировок путем привлечения к уголовной ответственности их лидеров, что позволяет более эффективно проводить разложенческую работу среди рядовых членов организованных преступных групп, добиваться ее распада и, в конечном счете, ликвидации преступного формирования;

- подрыв финансовой базы преступной организации путем перекрытия каналов еe преступных доходов, а также изъятия незаконно добытых капиталов, в частности, при активном использовании налогового законодательства;

- устранение причин и условий, способствующих существованию и функционированию преступной организации, в том числе путем проведения социально-экономических мероприятий по сокращению резервной армии организованной преступности и «сдерживания политиков, прибегающих к услугам преступных формирований».

Во многих зарубежных странах важнейшим инструментом подрыва экономической базы преступных сообществ выступает конфискация имущества. В уголовном законодательстве Японии, Франции, Азербайджана конфискация закреплена в качестве дополнительного наказания. В Дании,

${ }^{1}$ Рекомендуемые виды практики в области защиты свидетелей при производстве по уголовным делам, касающимся организованной преступности. Управление ООН по наркотикам и преступности. Нью-Йорк, 2008. C.7 // URL: http://sartraccc.ru/Pub_inter/protwitn.pdf (дата обращения: 4 сентября 2013 г.).

2 Организованная преступность в Японии: Научно-аналитический обзор. М., 1990. C. 39-40. Цит. по Мохов Е.А. Организованная преступность и национальная безопасность России. М., 2006. С. 73. 
Испании, Португалии, Боснии и Герцеговине, Македонии и ряде др. европейских стран конфискация рассматривается как иная мера уголовноправового воздействия за совершение преступлений.

В уголовных кодексах зарубежных государств закреплены различные подходы к определению перечня имущества, подлежащего конфискации. В одних странах к нему относятся: предметы, включенные законом или регламентом в число вредных; предметы и доходы, полученные в результате преступления; доходы, полученные от использования такого имущества. В других государствах (в Австрии, Германии, Нидерландах, Польше и др.) конфискация названных предметов в случае их сокрытия или израсходования может заменяться взысканием с преступников денежной суммы, соответствующей их стоимости ${ }^{1}$. В Англии Закон о полномочиях уголовных судов 1973 г. предоставляет судам право издавать приказы о конфискации любого имущества, находящегося во владении или под контролем преступника, которое было использовано в целях совершения любого преступления, способствовало его совершению или предназначалось для такого использования ${ }^{2}$.

При изучении зарубежного опыта противодействия криминализации органов власти значимой представляется финская антикоррупционная и антикриминальная модель. В ее основе лежит концепция Good Governance («хорошее управление») - осуществление действенной экономической, политической и административной власти на всех уровнях. Предполагается, что такое управление строится на основе демократических принципов разделения властей, народовластия, выборности и сменяемости должностных лиц, подотчетности институтов исполнительной власти законодательным органам, верховенства закона, политического плюрализма и независимости СМИ. Одновременно эффективность управления понимается и как

1 Цит. по Защепин М.Н. Конфискация имущества как мера противодействия коррупции // Рос. юрид. журнал. 2012. № 5.

2 Капинус Н.И., Капинус О.С. Конфискация имущества в уголовном праве современных стран // Закон. 2004. № 6. С. 64. 
достижение целей в установленные сроки и с минимальными затратами общественных ресурсов. Сочетание демократичности и эффективности взаимно предполагает и обусловливает друг друга.

Важнейшей составляющей эффективного государственного управления является доверие. Доверие к государству находится на высоком уровне и ставится во главу угла в процессе построения и функционирования развитого гражданского общества.

В Финляндии высока общественная уверенность в объективности, беспристрастности и законности правительства и государственных институтов. Демократизм, неполитизированный доступ к ключевым должностям государственной службы, а также прозрачность в процессе подготовки и принятия решений государственных и муниципальных органов вызывает у общества доверие к власти. Все это способствует поддержанию в гражданском сознании высокого уровня отторжения коррупции.

Основной принцип финской антикоррупционной политики заключается в понимании того, что коррупция не является изолированным феноменом. Поэтому она не требует отдельных законов, специальных органов, отдельной стратегии или плана действий. Напротив, эта политика интегрирована в общую политику государства, поскольку коррупция рассматривается и как часть преступного мира, и как результат неудовлетворительной работы органов власти, в том числе правоохранительных структур ${ }^{1}$.

Необходимо отметить, что противодействие криминализации органов публичной власти в зарубежных странах осуществляется с использованием гласных и негласных средств, форм и методов работы.

Основным источником информации для подразделений полиции, занимающихся разработкой преступных организаций (сообществ) являются лица, привлекаемые к негласному сотрудничеству.

1 Устойчивый иммунитет к коррупции: финская модель борьбы со взятками. По материалам Института Европы РАН. Президентский контроль. 2013. № 7. С. 42-46. 
«Использование секретных осведомителей или тайных агентов,говорится в одном из решений Верховного Суда США, - есть законная и правильная практика правоприменительных органов, которая оправдана интересами граждан. Без использования осведомителей многие преступления остались бы без возмездия, и правонарушители избежали бы привлечения к ответственности» ${ }^{1}$. Порядок использования специальных агентов при проведении оперативно-розыскных мероприятий регламентируется руководством для специальных агентов, утвержденным Конгрессом США в 1960 г. и Инструктивным письмом Генерального атторнея от 15 декабря 1976 $\Gamma$.

Важнейшим аспектом использования негласных источников по линии противодействия криминалитету является обеспечение их безопасности.

В п.6.1 - 6.4 Циркуляра по использованию осведомителей и других информаторов от 30 марта 1982 г. (ФРГ) закреплено:

«6.1. В интересах полиции при работе с осведомителями необходимо постоянно использовать все возможности для сохранения конфиденциальности, что полностью соответствует интересам этого малочисленного, подвергающегося особому риску, контингента.

6.2. В целях обеспечения конфиденциальности (конспиративности) сведения о личности информатора (осведомителя), неправомочное раскрытие которых угрожает важным общественным интересам, признаются служебной тайной.

6.3. Сотрудничество информаторов (осведомителей), содержание их информации и оценка их активности фиксируются в материалах расследования лишь в объеме, необходимом для уяснения его результатов. При этом необходимо тщательно следить, чтобы из этих записей нельзя было прийти к выводу о личности информаторов, их местопребывании и связях с полицией.

1 Противодействие преступлениям террористической и экстремистской направленности. Вопросы теории и практики оперативно-розыскной деятельности /Под ред. В.В. Волченкова, Б.П. Михайлова. М.: ЮНИТИ-ДАНА: Закон и право, 2013. С. 229. 
6.4. В соответствии с формулировкой разрешения на дачу показаний служащими полиции (параграф 54 раздела 6 УПК ФРГ 1950 г. (в ред. от 7 апреля 1987 г.); параграф 37 Закона ФРГ 2008 г. о регулировании правового положения служащих федеральных земель) определено, что на вопросы о конспиративных действиях в судебном процессе отвечать не разрешается» ${ }^{1}$.

Ключевое значение в борьбе с организованной преступностью имеет участие информаторов (осведомителей) в программах защиты свидетелей.

В Австралии, Австрии, Канаде, Латвии, Нидерландах, Норвегии и Соединенном Королевстве Великобритании и Северной Ирландии осведомители принимают полноправное участие в программах защиты свидетелей. Иначе обстоит дело в Германии, Словакии и Соединенных Штатах, где право на государственную защиту имеют только те свидетели, которые участвуют в уголовном процессе и дают показания. Сотрудники полиции, использующие осведомителей в качестве источников информации, сохраняют в тайне их имена и сведения об их личности и при определенных условиях и на эпизодической основе обеспечивают им физическую защиту.

При этом осведомители, включенные в программу защиты, должны прекратить свои отношения со следственными органами и органами, занимающимися сбором оперативной информации ${ }^{2}$.

Сегодня защита свидетелей рассматривается как важнейший инструмент противодействия организованной преступности.

Рассмотрим опыт некоторых зарубежных стран, в которых реализуются программы защиты свидетелей.

${ }^{1}$ Gesetz zur Regelung des Statusrechts der Beamtinnen und Beamten in den Laendern (Beamtenstatusgesetz vom 17. Juni 2008 (BGBl. I S. 1010)); Strafprozessordnung (StPO) in der Fassung der Bekanntmachung vom 7. April 1987 (BGBl. I S. 1074, 1319). См. также Противодействие преступлениям террористической и экстремистской направленности. Вопросы теории и практики оперативно-розыскной деятельности /Под ред. В.В. Волченкова, Б.П. Михайлова. М.: ЮНИТИ-ДАНА: Закон и право, 2013. С. 236.

${ }^{2}$ Рекомендуемые виды практики в области защиты свидетелей при производстве по уголовным делам, касающимся организованной преступности. Управление ООН по наркотикам и преступности. Нью-Йорк, 2008. С.22 // URL: http://sartraccc.ru/Pub_inter/protwitn.pdf (дата обращения: 4 сентября 2013 г.) 
Правовой основой колумбийской программы защиты свидетелей является Конституция 1991 года, согласно которой к числу основных обязанностей генеральной прокуратуры отнесена защита свидетелей, потерпевших и других участников уголовного процесса. Законом № 418 от 1997 года было учреждено три отдельных программы защиты свидетелей, доступ к которым предоставляется при обращении в генеральную прокуратуру. Первая программа предусматривает снабжение свидетелей информацией и рекомендациями по обеспечению их собственной безопасности, вторая предполагает наблюдение за свидетелями, а третья включает изменение личных данных и охватывает потерпевших, свидетелей, участников процесса и сотрудников генеральной прокуратуры. В соответствии с законом участники могут быть исключены из программы защиты на любом из следующих оснований:

а) необоснованный отказ подчиниться судебной процедуре;

b) несогласие с планами или программами переселения;

с) совершение противоправных действий, серьезно затрагивающих процедуру защиты;

d) отказ от участия по собственному желанию ${ }^{1}$.

В 2001 г. в Германии был принят Закон об унификации мер защиты свидетелей, подвергающихся риску (Gesetz zur Harmonisierung des Schutzes gefaehrdeter Zeugen (Zeugenschutz-Harmonisierungsgesetz - ZSHG)) ${ }^{2}$. В данном Законе регламентируются следующие вопросы:

а) категории свидетелей, которые могут рассматриваться в качестве потенциальных участников программы, и соответствующие критерии их включения и исключения из нее. В соответствии с Законом к участию в программе могут допускаться лица, подвергающиеся угрозе из-за своей

${ }^{1}$ Там же. C.12 // URL: http://sartraccc.ru/Pub_inter/protwitn.pdf (дата обращения: 10 сентября 2013 г.).

${ }^{2}$ BGBl. I S. 3510. 
готовности дать свидетельские показания по делам, касающимся серьезных преступлений или организованных преступных группировок ${ }^{1}$;

b) полномочия по принятию решений и осуществлению мер защиты. Вопросы включения в программу решаются подразделением по защите совместно с прокурором². Подразделения по защите вправе принимать самостоятельные решения о необходимых мерах, руководствуясь тяжестью совершенного преступления, степенью риска, правами обвиняемого и вероятными последствиями принимаемых мер ${ }^{3}$;

c) сохранение конфиденциальности персональных данных защищаемых свидетелей. Личные дела защищаемых свидетелей ведутся подразделениями по защите и не приобщаются к материалам следствия. Сведения о защищаемых лицах могут предоставляться только по запросу обвинения ${ }^{4}$;

d) условия снабжения конспиративными личными данными и удостоверяющими их персональными документами, а также пособия, предоставляемые на время защиты ${ }^{5}$.

Программа защиты свидетелей в Германии осуществляется силами бюро по защите свидетелей, учрежденных на федеральном уровне и на уровне каждой из земель. Федеральный департамент уголовной полиции несет ответственность за защиту свидетелей по делам федерального значения и за координацию работы на национальном и международном уровнях.

Заслуживает внимания итальянский опыт защиты свидетелей по уголовным делам, связанным с преступной деятельностью мафии.

${ }^{1}$ Абзацы 1 и 2 параграфа 1 Закона ФРГ от 11 декабря 2001 г. об унификации мер защиты свидетелей, подвергающихся риску.

2 Абзац 4 параграфа 2 Закона об унификации мер защиты свидетелей, подвергающихся риску.

3 Абзац 2 параграфа 2 Закона об унификации мер защиты свидетелей, подвергающихся риску.

${ }^{4}$ В соответствии с абзацем 1 параграфа 4 Закона ФРГ 2001 г. об унификации мер защиты свидетелей, подвергающихся риску, бюро по защите свидетелей в целях обеспечения безопасности вправе отказать в доступе к персональным данным о защищаемом лице. риску.

Параграф 5 Закона об унификации мер защиты свидетелей, подвергающихся 
В соответствии с Итальянским Законодательным декретом № 82 от 15 марта 1991 года с поправками, внесенными в 2001 году, определены категории защищаемых лиц, используемые виды защиты, порядок принятия решений о включении в программу защиты ${ }^{1}$. К числу лиц, которым может предоставляться защита, относятся:

- свидетели и осведомители по делам, касающимся наркотиков, деятельности мафии или умышленных убийств;

- свидетели любого преступления, наказываемого лишением свободы на срок от 5 до 20 лет;

- находящиеся в опасности близкие лиц, сотрудничающих с органами юстиции.

Если защита предоставляется осужденным к лишению свободы, такие лица должны до их включения в программу защиты свидетелей отбыть не менее одной четверти назначенного срока наказания или, если они приговорены к пожизненному заключению, не менее 10 лет лишения свободы.

Защита может осуществляться в рамках «временного плана», «особых мер» и «специальной программы защиты». «Временный план» предусматривает переселение и выплату пособия в течение 180 дней. «Особые меры» включают защиту и социальную реинтеграцию переселенных лиц. «Специальная программа защиты» предусматривает переселение, выдачу временных удостоверений личности, финансовую поддержку и (в качестве крайней меры) юридическое оформление новых личных данных. Изменения личных данных подлежат утверждению Центральной службой защиты, несущей ответственность за осуществление мер защиты и обеспечение их соблюдения.

Решения о включении в программу принимаются центральной комиссией в составе:

${ }^{1}$ Рекомендуемые виды практики в области защиты свидетелей при производстве по уголовным делам, касающимся организованной преступности. Управление ООН по наркотикам и преступности. Нью-Йорк, 2008. С.13-14 // URL: http://sartraccc.ru/Pub_inter/protwitn.pdf (дата обращения: 4 сентября 2013 г.). 
- заместителя государственного секретаря Министерства внутренних дел;

- двух судей или прокуроров;

- пяти экспертов по проблемам организованной преступности.

Защита свидетелей может также осуществляться по линии постоянных и специальных международных уголовных судов (Международного уголовного суда, Международного уголовного трибунала для бывшей Югославии и Международного уголовного трибунала для Руанды).

Элементом обеспечения безопасности оперативных источников правоохранительных органов является обеспечение конфиденциальности сведений об их персональных данных. Так, в 1982 г. конгресс США принял поправку к Закону о национальной безопасности 1947 г., которая предусматривает уголовную ответственность за разглашение фамилий негласных сотрудников и осведомителей ФБР, внедренных в преступные организации. Лица, допустившие раскрытие такой информации, подлежат штрафу в сумме до 50 тыс. долларов, либо тюремному заключению на срок до 10 лет, либо совокупности этих наказаний.

Сведения о личности негласных сотрудников и осведомителей разведки и контрразведки в ФРГ признаются государственной тайной. Их умышленное или неосторожное разглашение наказываются лишением свободы на срок от 6 месяцев до 5 лет (параграфы 95 и 97 УК ФРГ 1871 г. (в ред. от 13 ноября 1998 г.)) ${ }^{1}$. Те же данные, но относящиеся к сотрудникам и информаторам полиции, составляют ведомственную тайну, за разглашение которой в соответствии с пунктом 353-В УК ФРГ налагается денежный штраф или назначается наказание в виде лишения свободы на срок до 5 лет².

В борьбе с наиболее опасными видами преступлений зарубежная криминальная полиция практикует проведение тайных операций в отношении преступных сообществ (организаций).

\footnotetext{
${ }^{1}$ Strafgesetzbuch (StGB) in der Fassung der Bekanntmachung vom 13. November 1998 (BGBl. I S. 3322)

2 Ebenda.
} 
Данный вид деятельности регламентируется инструкциями Генерального атторнея, изданными в январе 1981 г., и признан Федеральным Конгрессом исключительно эффективным оружием в борьбе с коррупцией и организованной преступностью.

Тайная операция обычно заканчивается судебным процессом, на котором в качестве главного свидетеля обвинения выступает секретный агент ${ }^{1}$.

В Постановлении Европейского Суда по правам человека по делу «Быков (Bykov) против Российской Федерации» (жалоба № 4378/02) оспаривалась допустимость доказательств, полученных следственными органами в ходе тайной операции (негласных оперативно-розыскных мероприятий), и толкование судом вещественных доказательств и свидетельских показаний ${ }^{2}$.

В сентябре 2000 г. Быков предположительно поручил В., представителю своего окружения, убить своего бывшего делового партнера $\mathrm{C}^{3}$. В. не выполнил поручение, сообщил о нем в ФСБ России и выдал пистолет, предположительно полученный от Быкова.

После возбуждения уголовного дела в отношении Быкова по подозрению в подготовке убийства органы внутренних дел и федеральной службы безопасности разработали замысел тайной операции для получения доказательств умысла Быкова.

1 Противодействие преступлениям террористической и экстремистской направленности. Вопросы теории и практики оперативно-розыскной деятельности / Под ред. В.В. Волченкова, Б.П. Михайлова. М.: ЮНИТИ-ДАНА: Закон и право, 2013. С. 243.

2 Постановление Европейского Суда по правам человека по делу «Быков (Bykov) против Российской Федерации» (жалоба № 4378/02) // Бюллетень Европейского Суда по правам человека. Российское издание. 2009. № 6.

${ }_{3}$ С 1997 по 1999 год Быков был председателем совета директоров Красноярского алюминиевого завода (КрАЗ). До своего задержания в октябре 2000 года он являлся крупным акционером и должностным лицом корпорации ОАО «КрасэнергомашХолдинг», учредителем ряда аффилированных организаций, депутатом Законодательного собрания Красноярского края. 
29 сентября 2000 г. милиция инсценировала обнаружение двух трупов в доме С. Через СМИ была официально распространена информация о том, что в одном из убитых опознан С. Другим был его партнер по бизнесу И.

3 октября 2000 г. В., действуя по указанию милиции, посетил заявителя по месту его жительства. На его теле был скрыт радиопередатчик, разговор негласно записывался находившимся на улице сотрудником милиции. В. был принят Быковым в «гостевом доме». В соответствии с указаниями В. завязал с Быковым разговор, сообщив ему, что совершил убийство. В доказательство его совершения он передал Быкову несколько предметов, взятых у С. и И.: заверенную копию технико-экономического обоснования горнодобывающего проекта, помеченную специальным химическим веществом, двое часов, принадлежащих С. и И., и 20 тыс. долларов США. В конце разговора В. забрал деньги по предложению Быкова.

4 октября 2000 г. жилище Быкова было подвергнуто обыску. Были изъяты несколько часов, включая принадлежащие С. и И. Проведенный химический анализ выявил наличие на руках Быкова химического вещества, которым было помечено технико-экономическое обоснование. Он был задержан.

27 февраля 2001 г. Быков подал жалобу прокурору Северо-Западного округа г. Москвы, указав, что его преследование является незаконным из-за обилия процессуальных нарушений его прав, включая несанкционированное вторжение в его жилище и применение радиопередатчика. 2 марта 2001 г. прокурор отклонил его жалобу, в частности, установив, что Быков впустил В. в свое жилище добровольно, следовательно, вторжение не имело места. Он также пришел к выводу о том, что судебное разрешение на использование радиопередатчика не требовалось, поскольку в соответствии с Федеральным законом «Об оперативно-розыскной деятельности» оно необходимо при контроле сообщений, передаваемых по сетям электрической и почтовой связи, которые при данной негласной операции не использовались. 
19 июня 2002 г. Мещанский районный суд г. Москвы вынес приговор, признав Быкова виновным в сговоре с целью убийства и сговоре с целью приобретения, хранения и ношения огнестрельного оружия. Суд приговорил Быкова к шести с половиной годам лишения свободы, но, засчитав срок предварительного содержания под стражей, признал наказание условным с пятилетним испытательным сроком.

1 октября 2002 г. Московский городской суд оставил вынесенный Быкову приговор без изменения.

22 июня 2004 г. Верховный Суд Российской Федерации рассмотрел дело заявителя в порядке надзора. Он изменил приговор от 19 июня 2002 г. и определение суда кассационной инстанции от 1 октября 2002 г., уточнив правовую квалификацию одного из преступлений, совершенных заявителем. Он признал заявителя виновным в «подстрекательстве к совершению преступления, включающего убийство».

Обращаясь к обстоятельствам настоящего дела, Европейский Суд отметил, что Быков содержался под стражей до и во время суда 1 год, 8 месяцев и 15 дней. В этот период суды рассматривали ходатайства заявителя об освобождении не менее 10 раз, всякий раз отказывая на основании тяжести обвинений и вероятности того, что он скроется, воспрепятствует производству по уголовному делу и окажет давление на свидетелей. Кроме того, начиная с 7 сентября 2001 г. в решениях о продлении срока содержания заявителя под стражей не указывался срок, что означало, что он должен содержаться под стражей до окончания судебного разбирательства.

Европейский Суд пришел к выводу, что власти не смогли указать относимых и достаточных причин, оправдывающих продление срока содержания заявителя под стражей. Соответственно, имело место нарушение пункта 3 статьи 5 Конвенции (права на судебное разбирательство в течение разумного срока или на освобождение до суда).

Рассматривая жалобу заявителя на незаконное вторжение в его жилище и нарушение права на уважение личной жизни прослушиванием и записью 
его разговора с В., Европейский Суд пришел к выводу, что заявитель пользовался весьма незначительными гарантиями в процедуре организации и реализации прослушивания его разговора с В. Соответственно, по мнению Европейского Суда, имело место нарушение статьи 8 Конвенции (право на уважение частной и семейной жизни).

Заявитель также жаловался на то, что органы внутренних дел вынудили его с помощью обмана свидетельствовать против себя в разговоре с В. и что суд принял запись этого разговора в качестве доказательства при рассмотрении дела. Он указывал, что его разговор с В. фактически представлял собой скрытый допрос, не сопровождавшийся какими-либо процессуальными гарантиями.

Европейский Суд отметил, что в настоящем деле Быков в отсутствие какого-либо давления принял В. в своем «гостевом доме», беседовал с ним и делал конкретные замечания по вопросам, затронутым В. В отличие от заявителя по делу «Аллан против Соединенного Королевства» он не содержался под стражей, но находился на свободе в своем помещении, в котором присутствовали охрана и другой персонал ${ }^{1}$. Природа его отношений c B. - подчиненное положение последнего по отношению к заявителю - не предписывала ему какой-либо особой формы поведения. Иными словами, Быков мог по собственной воле встретиться с В. и беседовать с ним или отказаться сделать это. Как представляется, он проявлял готовность продолжать разговор, начатый В., поскольку тема представляла для него личный интерес. Таким образом, Европейский Суд не убежден, что получение доказательств было опорочено элементом принуждения или подавления. Европейский Суд также придал значение тому обстоятельству, что, оценивая факты, национальные суды прямо не опирались на запись разговора заявителя с В. Кроме того, негласная запись играла ограниченную роль в сложной системе доказательств, которые подверглись оценке суда.

${ }^{1}$ Постановление Европейского Суда по правам человека от 5 ноября 2002 г. по делу «Алан против Соединенного Королевства» (Allan-United Kingdom) (№ 48539/99) // Бюллетень Европейского Суда по правам человека. Российское издание. 2003. № 4. 
Исследовав гарантии, сопровождавшие оценку допустимости и достоверности указанных доказательств, природу и степень предполагаемого принуждения и характер использования материала, полученного при тайной операции (негласных оперативно-розыскных мероприятиях), Европейский Суд пришел к выводу, что в целом разбирательство по делу заявителя не противоречило требованиям справедливого судебного разбирательства.

Многолетний зарубежный опыт показывает, что внедрение оперативного работника в преступную группу требует решения таких важных вопросов, как:

- наличие правовой основы внедрения в преступную организацию (сообщество);

- подбор кандидата на оперативное внедрение;

- подготовка сотрудника к внедрению;

- оперативное прикрытие сотрудника и осуществление руководства его деятельностью;

- материальное и техническое обеспечение оперативного внедрения;

- адаптация сотрудника (после его вывода из разработки преступной организации) к деятельности в обычных условиях.

В США решение о внедрении оперативного сотрудника, проблемы процессуального или материально-правового характера, возникающие при использовании этих сотрудников, должны обязательно согласовываться с прокуратурой. Если такое соглашение своевременно не могло быть осуществлено по каким-либо причинам, то прокуратура должна быть сразу проинформирована об этом. Ей предоставлено право решения вопроса о допустимости дальнейшего использования данного оперативного работника. Это решение выносит руководитель соответствующего органа прокуратуры или непосредственно ему подчиненный прокурор ${ }^{1}$.

Внедрение в преступные сообщества сотрудников и осведомителей широко практикуют и правоохранительные органы ФРГ. Однако

\footnotetext{
${ }^{1}$ Там же. С. 248.
} 
осуществление подобных операций значительно затрудняется их правовой неурегулированностью ${ }^{1}$.

Проведенный анализ международно-правовых основ и зарубежного опыта противодействия криминализации органов публичной власти свидетельствует о наличии эффективных правовых и организационных механизмов, позволяющих предотвращать назначение и избрание на «ответственные» должности представителей криминалитета, раскрывать и расследовать коррупционные схемы в партийных структурах и государственном аппарате, привлекать лидеров и участников преступных организаций (сообществ) к уголовной ответственности. С учетом российской специфики те или иные элементы международной и зарубежной правотворческой и правоприменительной практики могут быть использованы отечественным законодателем при совершенствовании правовой базы противодействия криминализации органов публичной власти.

1 Так, использование документов оперативного прикрытия, создания соответствующих легендированных организаций и учреждений требует специального разрешения министра внутренних дел ФРГ. В соответствии с абзацем 1 параграфа 5 Закона ФРГ от 11 декабря 2001 г. об унификации мер защиты свидетелей, подвергающихся риску, удостоверения личности и паспорта прикрытия не могут выдаваться лицам, не являющимся немцами (гражданами ФРГ) / Gesetz zur Harmonisierung des Schutzes gefaehrdeter Zeugen (Zeugenschutz-Harmonisierungsgesetz - ZSHG)) // BGB1. I S. 3510 . 


\section{6. ПРЕДЛОЖЕНИЯ ПО СОВЕРШЕНСТВОВАНИЮ ОТДЕЛЬНЫХ ЗАКОНОДАТЕЛЬНЫХ АКТОВ РОССИЙСКОЙ ФЕДЕРАЦИИ В РАМКАХ ПРОТИВОДЕЙСТВИЯ КРИМИНАЛИЗАЦИИ ОРГАНОВ ПУБЛИЧНОЙ ВЛАСТИ}

Практическое осуществление перечисленных в работе направлений противодействия криминализации органов публичной власти базируется на совершенствовании законодательных

актов, регулирующих соответствующие общественные отношения.

В целях модернизации действующего законодательства необходимо усиление требований к замещению государственных должностей Российской Федерации, государственных должностей субъектов Российской Федерации, должностей гражданской, военной, правоохранительной и муниципальной службы.

По «странному» стечению обстоятельств в российском законодательстве требования к народным представителям - депутатам и выборным должностным лицам всех уровней - существенно мягче, чем, например, требования к судьям, прокурорам, сотрудникам правоохранительных органов и спецслужб.

Согласно пункту 1 статьи 4 Закона Российской Федерации «О статусе судей в Российской Федерации», пункту 2 статьи 40.1 Закона Российской Федерации «О прокуратуре Российской Федерации», пунктам 2 и 3 части 1 статьи 29 Федерального закона «О полиции», подпункту 4 пункта 5 статьи 18 Федерального закона «О государственной охране», пункту «в» части 3 статьи 16 Федерального закона «О федеральной службе безопасности», пункту 2 части 4 статьи 16 Федерального закона «О Следственном комитете Российской Федерации» гражданин, имеющий судимость (в том числе снятую или погашенную), а также в отношении которого уголовное преследование прекращено за истечением срока давности, в связи с примирением сторон, вследствие акта об амнистии или в связи с деятельным раскаянием, никогда не сможет поступить на службу или на работу в органы 
прокуратуры, полиции, органы государственной охраны, федеральной службы безопасности, следственные органы, не может быть назначен на должность судьи. Однако тот же самый гражданин беспрепятственно изберется в Государственную Думу Федерального Собрания Российской Федерации, законодательный орган государственной власти субъекта Российской Федерации, в представительный орган муниципального образования, на любую выборную должность!

В Федеральный закон «Об основных гарантиях избирательных прав и права на участие в референдуме граждан Российской Федерации» было бы целесообразно внести следующие изменения. Подпункты «а» и «б» пункта 3.2 статьи 4 комментируемого Федерального закона изложить в редакции: «Не имеют права быть избранными граждане Российской Федерации: а) имеющие судимость, в том числе снятую или погашенную ${ }^{1}$; б) в отношении которых уголовное преследование было прекращено за истечением срока давности, в связи с примирением сторон, вследствие акта об амнистии, в связи с деятельным раскаянием».

Если данные предложения о внесении изменений в Федеральный закон «О статусе члена Совета Федерации и статусе депутата Государственной Думы Федерального Собрания Российской Федерации», Федеральный закон «Об общих принципах организации законодательных (представительных) и исполнительных органов государственной власти субъектов Российской Федерации» и Федеральный закон «Об основных гарантиях избирательных прав и права на участие в референдуме граждан Российской Федерации» не получат полноценное развитие в законодательных актах Российской Федерации, то минимально необходимым средством борьбы с криминализацией органов публичной власти представляется сделать хотя бы обязательность указания кандидатами в депутаты и (или) на выборные должности всех имеющихся судимостей (в т.ч. снятых и погашенных).

1 Лицо должно быть осуждено за деяния, признаваемые преступными действующим Уголовным кодексом Российской Федерации. 
Пункт 58 статьи 2 Федерального закона «Об основных гарантиях избирательных прав и права на участие в референдуме граждан Российской Федерации» предлагается изложить в следующей редакции: «Сведения о судимостях кандидата - сведения о судимостях с указанием номера (номеров) и наименования (наименований) статьи (статей) Уголовного кодекса Российской Федерации, на основании которой (которых) был осужден кандидат, наименования суда, вынесшего приговор, срока и вида наказания, даты освобождения, а также статьи (статей) уголовного кодекса, принятого в соответствии с Основами уголовного законодательства Союза ССР и союзных республик, статьи (статей) закона иностранного государства, если кандидат был осужден в соответствии с указанными законодательными актами за деяния, признаваемые преступлением действующим Уголовным кодексом Российской Федерации».

Эффективность законодательного противодействия криминализации выборных органов власти можно было бы повысить путем дополнения пункта 3.2 статьи 4 Федерального закона «Об основных гарантиях избирательных прав и права на участие в референдуме граждан Российской Федерации» подпунктом «д» - «осужденные за совершение преступлений, предусмотренных статьями 141, 141.1, 142, 142.1 Уголовного кодекса Российской Федерации» ${ }^{1}$. Аналогичные правовые положения следует включить в часть 4.2 статьи 5 Федерального закона «О выборах депутатов Государственной Думы Федерального Собрания Российской Федерации» и пункт 5.2 статьи 3 Федерального закона «О выборах Президента Российской Федерации». Таким образом, лица, имеющие судимость по делам, связанным с нарушением законодательства о выборах и референдумах, не смогут избираться в органы государственной власти и органы местного самоуправления.

1 Данное предложение приобретет актуальность, если не будут реализованы сформулированные автором меры по ограничению пассивного избирательного права в связи с прекращением уголовного преследования за истечением срока давности, в связи с примирением сторон, вследствие акта об амнистии, в связи с деятельным раскаянием. 
Претенденты на замещение государственных должностей Российской Федерации, государственных должностей субъектов Российской Федерации, должностей гражданской, военной, правоохранительной и муниципальной службы должны, как представляется, проходить обязательную антикриминальную проверку по оперативно-справочным учетам и автоматизированным информационным системам органов внутренних дел и безопасности.

С учетом данной инициативы потребуется внесение изменений в п.31 ч.1 ст. 12 Федерального закона «О полиции» после фразы «принятых в связи с этим мерах» в следующей редакции:

«предоставлять по запросам избирательных комиссий, комиссий референдума, органов федеральной службы безопасности сведения: о наличии судимости; о фактах уголовного преследования или о прекращении уголовного преследования за истечением срока давности, в связи с примирением сторон, вследствие акта об амнистии, в связи с деятельным раскаянием; о факте нахождения в розыске; о заведении дел оперативного учета у лиц, являющихся кандидатами на должность Президента Российской Федерации, кандидатами в депутаты законодательных (представительных) органов государственной власти, кандидатами на выборные должности местного самоуправления, кандидатами на замещение государственных должностей Российской Федерации, государственных должностей субъектов Российской Федерации, должностей гражданской, военной, правоохранительной и муниципальной службы; далее - без изменений»

Статью 10 Федерального закона «О федеральной службе безопасности» следовало бы дополнить следующей нормой:

«Органы федеральной службы безопасности осуществляют проверку претендентов на замещение государственных должностей Российской Федерации, государственных должностей субъектов Российской Федерации, должностей гражданской, военной, правоохранительной и муниципальной службы». 
Усиление требований к замещению государственных должностей Российской Федерации, государственных должностей субъектов Российской Федерации, должностей гражданской, военной, правоохранительной и муниципальной службы должно быть неразрывно связано с расширением перечня должностных лиц, представляющих сведения о своих доходах, расходах, об имуществе и обязательствах имущественного характера, а также о доходах, расходах, имуществе и обязательствах имущественного характера своих супруги (супруга) и несовершеннолетних детей; уточнением требований о расходах указанных должностных лиц; введением антикоррупционных ограничений в отношении запрета иметь зарегистрированное за пределами Российской Федерации право собственности на имущество.

На наш взгляд, коррупциогенный фактор действующей редакции законодательства о противодействии коррупции будет устранен, если в ч.1 ст.3 Федерального закона от 3 декабря 2012 г. № 230-Ф3 «О контроле за соответствием расходов лиц, замещающих государственные должности, и иных лиц, их расходам» и смежное антикоррупционное законодательство будет включена формулировка: Лицо, замещающее (занимающее) одну из должностей, указанных в пункте 1 части 1 статьи 2 настоящего Федерального закона, обязано представлять сведения о своих расходах, а также о расходах своих супруги (супруга) и несовершеннолетних детей по каждой сделке по приобретению земельного участка, другого объекта недвижимости, транспортного средства, ценных бумаг, акций (долей участия, паев в уставных (складочных) капиталах организаций), если суммарные расходы превысят общий доход лица и его супруги (супруга) по основному месту их службы (работы) за год, предшествующий сделке, и об источниках получения средств, за счет которых совершена сделка.

В настоящее время антикоррупционные ограничения в отношении вкладов должностных лиц в иностранных банках и иностранных финансовых инструментов распространяются только на лиц, замещающих государственные должности Российской Федерации, должности федеральной государственной службы, назначение на которые и освобождение от которых 
осуществляются Президентом Российской Федерации, Правительством Российской Федерации, должности заместителей руководителей федеральных органов исполнительной власти, глав городских округов, глав муниципальных районов и ряд других должностей из соответствующего перечня. При этом установленные законом ограничения никак не затрагивают финансовой основы коррупционной деятельности возможности беспрепятственно выводить денежные средства за пределы территории Российской Федерации и вкладывать их в недвижимое имущество за рубежом.

Гражданин, зарегистрировавший за пределами Российской Федерации право собственности на имущество, в соответствии с пунктом «д» части 3 статьи 16 Федерального закона «О федеральной службе безопасности», подпунктом 6 пункта 5 статьи 18 Федерального закона «О государственной охране» подлежит увольнению из органов федеральной службы безопасности или органов государственной охраны. Но если этот гражданин избирается или уже избран депутатом Государственной Думы Федерального Собрания Российской Федерации, депутатом законодательного органа субъекта Российской Федерации, депутатом представительного органа муниципального образования, высшим должностным лицом субъекта Российской Федерации, назначен Председателем Счетной палаты Российской Федерации, заместителем Председателя или аудитором Счетной палаты Российской Федерации, членом избирательной комиссии с правом решающего голоса, то никаких проблем для него не возникает!

При этом полномочия депутатов, выборных должностных лиц, лиц, замещающих государственные должности, и характер принимаемых ими политико-правовых решений непосредственно затрагивают права и свободы граждан. Противоправное использование властных полномочий может представлять угрозу единству и территориальной целостности, обороноспособности государства, единству правового и экономического пространства Российской Федерации. Наличие же имущества на праве собственности за пределами Российской Федерации влияет на объективное исполнение должностных обязанностей и депутатских полномочий, способно 
привести к причинению вреда законным интересам граждан, организаций и государства.

В целях устранения названных «двойных стандартов» часть 1 статьи 4 Федерального закона «О статусе члена Совета Федерации и статусе депутата Государственной Думы Федерального Собрания Российской Федерации» предлагается дополнить пунктом «к», в котором в качестве самостоятельного основания досрочного прекращения полномочий члена Совета Федерации, депутата Государственной Думы будет закреплено приобретение зарегистрированного за пределами Российской Федерации права собственности на имущество.

Установление фактов открытия или наличия счетов (вкладов), хранения наличных денежных средств и ценностей в иностранных банках, расположенных за пределами территории Российской Федерации, владения и (или) пользования иностранными финансовыми инструментами, приобретение зарегистрированного за пределами Российской Федерации права собственности на имущество следовало бы закрепить в качестве оснований досрочного освобождения от должности Председателя Счетной палаты Российской Федерации, заместителя Председателя и аудиторов Счетной палаты Российской Федерации в ч.8 ст.7, ч.8 ст.8 и ч.10 ст.9 Федерального закона «О Счетной палате Российской Федерации».

Пункт 4 статьи 12 Федерального закона «Об общих принципах организации законодательных (представительных) и исполнительных органов государственной власти субъектов Российской Федерации» необходимо изложить в следующей редакции: «Утрата депутатом гражданства Российской Федерации, приобретение им гражданства иностранного государства либо получение им вида на жительство или иного документа, подтверждающего право на постоянное проживание гражданина Российской Федерации на территории иностранного государства, приобретение зарегистрированного за пределами Российской Федерации права собственности на имущество, является основанием для досрочного прекращения депутатских полномочий». 
Аналогичную норму можно было бы включить в подпункт «ж» пункта 8 статьи 29 Федерального закона «Об основных гарантиях избирательных прав и права на участие в референдуме граждан Российской Федерации» (основания прекращения полномочий члена комиссии с правом решающего голоса):

установление фактов открытия или наличия счетов (вкладов), хранения наличных денежных средств и ценностей в иностранных банках, расположенных за пределами территории Российской Федерации, владения и (или) пользования иностранными финансовыми инструментами, приобретение зарегистрированного за пределами Российской Федерации права собственности на имущество.

Антикоррупционные законы содержат различные подходы к оценке материального положения, источников доходов, законности и прозрачности расходов отдельных должностных лиц и правовым последствиям конфликта интересов у данных лиц, непредставления этими должностными лицами сведений о доходах, расходах, имуществе и обязательствах имущественного характера в установленные сроки, а также представления заведомо недостоверных или неполных сведений.

Так, в случае непредставления сведений о доходах, расходах, имуществе и обязательствах имущественного характера в установленные сроки, а также представления заведомо недостоверных сведений сотрудники правоохранительных органов, военнослужащие, гражданские и муниципальные служащие подлежат увольнению со службы, а члены Правительства Российской Федерации, высшие должностные лица субъектов Российской Федерации, члены избирательных комиссий, судьи продолжают исполнять свои обязанности и замещать должность.

Поэтому перечень оснований освобождения от должности заместителей Председателя Правительства Российской Федерации и федеральных министров в статьях 9-11 Федерального конституционного закона «О Правительстве Российской Федерации» предлагается дополнить следующим образом: 
выявление фактов коррупции, неурегулирование конфликта интересов, непредставление сведений о своих доходах, расходах, об имуществе и обязательствах имущественного характера, а также о доходах, расходах, имуществе и обязательствах имущественного характера своих супруги (супруга) и несовершеннолетних детей либо представление заведомо недостоверных или неполных сведений.

В число оснований досрочного прекращения полномочий высшего должностного лица субъекта Российской Федерации, закрепленных в статье 19 Федерального закона «Об общих принципах организации законодательных (представительных) и исполнительных органов государственной власти субъектов Российской Федерации», целесообразно включить непредставление сведений о своих доходах, расходах, об имуществе и обязательствах имущественного характера, а также о доходах, расходах, имуществе и обязательствах имущественного характера своих супруги (супруга) и несовершеннолетних детей либо представление заведомо недостоверных или неполных сведений.

В пункт 8 статьи 29 Федерального закона «Об основных гарантиях избирательных прав и права на участие в референдуме граждан Российской Федерации» логично добавить подпункт «з» следующего содержания: полномочия члена комиссии с правом решающего голоса прекращаются в случае ... «непредставления сведений о своих доходах, расходах, об имуществе и обязательствах имущественного характера, а также о доходах, расходах, имуществе и обязательствах имущественного характера своих супруги (супруга) и несовершеннолетних детей либо представления заведомо недостоверных или неполных сведений».

Пункт 5 статьи 8.1 Закона Российской Федерации «О статусе судей в Российской Федерации» предлагается изложить в редакции:

«В случае непредставления сведений о доходах, расходах, имуществе и обязательствах имущественного характера в установленные сроки, а также представления заведомо недостоверных сведений полномочия судьи прекращаются». 
Данной норме должен коррелировать пункт 1 ст. 14 Закона Российской Федерации «О статусе судей в Российской Федерации», в который необходимо добавить «непредставление сведений о своих доходах, расходах, об имуществе и обязательствах имущественного характера, а также о доходах, расходах, имуществе и обязательствах имущественного характера своих супруги (супруга) и несовершеннолетних детей либо представление заведомо недостоверных или неполных сведений».

Таким образом, курсу на проведение единой политики противодействия коррупции в Российской Федерации будет соответствовать унификация ограничений, запретов и обязанностей государственных и муниципальных служащих, лиц, замещающих государственные должности Российской Федерации, государственные должности субъектов Российской Федерации, должности глав муниципальных образований, муниципальные должности.

Усиление требований к замещению государственных должностей Российской Федерации, государственных должностей субъектов Российской Федерации, должностей гражданской, военной, правоохранительной и муниципальной службы в т.ч. в части представления сведений о доходах, расходах, об имуществе и обязательствах имущественного характера должно системно дополняться правовыми механизмами регулярного проведения антикоррупционных (антикриминальных) расследований.

Предлагается инициировать разработку и принятие Федерального закона «Об антикоррупционных (антикриминальных) расследованиях».

В предмет антикоррупционных (антикриминальных) расследований должны входить:

1) факты коррупционных проявлений в органах государственной власти и местного самоуправления, правоохранительных и контрольноревизионных органах, государственных корпорациях, государственных и муниципальных учреждениях;

2) обстоятельства, связанные с избранием лиц, причастных к организованной преступной деятельности, в законодательные органы власти, 
выборные органы местного самоуправления, представительные органы муниципальных образований, на выборные должности;

3) обстоятельства, связанные с назначением лиц, причастных к организованной преступной деятельности, на государственные должности Российской Федерации, государственные должности субъектов Российской Федерации, муниципальные должности, должности правоохранительной и военной службы, должности в государственных корпорациях, государственных и муниципальных учреждениях;

4) факты лоббирования должностными лицами органов государственной власти и местного самоуправления, правоохранительных и контрольно-ревизионных органов, государственных корпораций, государственных и муниципальных учреждений интересов предприятий, организаций, учреждений и бизнес-структур, принадлежащих или аффилированных с лицами, причастными к организованной преступной деятельности;

5) факты грубого нарушения финансовой дисциплины, выразившиеся в нецелевом расходовании бюджетных средств и средств государственных внебюджетных фондов, неправомерного получения кредитов, управления и распоряжения федеральной, региональной и муниципальной собственностью.

В данном Федеральном законе следует закрепить перечень субъектов, обладающих правом инициировать и проводить антикоррупционные (антикриминальные) расследования, гарантии организационного, финансового и материально-технического обеспечения проводимых расследований, права и обязанности лиц, привлеченных к расследованию.

Антикоррупционные (антикриминальные) расследования могут осуществляться Общественной палатой Российской Федерации, Общественными палатами субъектов Российской Федерации, Уполномоченным по правам человека в Российской Федерации, Уполномоченными по правам человека в субъектах Российской Федерации, антикоррупционными общественными организациями. Организационной формой подобных расследований может являться деятельность комиссии, 
созданной инициаторами антикоррупционного (антикриминального) расследования. Данную комиссию предлагается наделить правами: запрашивать у государственных и муниципальных органов, учреждений и организаций документы и информацию, необходимые для расследования; приглашать для дачи объяснений по расследуемым фактам и обстоятельствам должностных лиц, экспертов, специалистов; выезжать на место расследуемых событий. Финансовое и материально-техническое обеспечение может осуществляться за счет бюджетных средств, выделяемых на обеспечение деятельности общественных палат, уполномоченных по правам человека.

Составной частью общегосударственного механизма противодействия коррупции и криминализации органов власти является антикоррупционная экспертиза нормативных правовых актов и проектов нормативных правовых актов.

В рамках совершенствования методики антикоррупционной экспертизы нормативных правовых актов ряд федеральных законов и подзаконных актов нуждается в определенной корректировке.

Формулировки частей 7-10 статьи 91 Федерального закона «О выборах депутатов Государственной Думы Федерального Собрания Российской Федерации», связанные с возможностью отмены решения Центральной избирательной комиссии Российской Федерации о регистрации списка кандидатов, об отказе в его регистрации, об исключении группы кандидатов из списка кандидатов, с отменой регистрации федерального списка кандидатов, отменой регистрации кандидатов, включенных в зарегистрированный федеральный список кандидатов, с исключением региональной группы кандидатов из федерального списка, допускают возможность выборочного правоприменения и нарушения равного статуса субъектов избирательного процесса. Диспозитивное установление возможности совершения органом государственной власти действий в отношении граждан и организаций является коррупционным фактором. Поэтому словосочетание «может быть» в частях 7-10 статьи 91 Федерального 
закона «О выборах депутатов Государственной Думы Федерального Собрания Российской Федерации» предлагается заменить словосочетанием «должна быть».

Коррупционная возможность закреплена в пункте 7 статьи 70 Федерального закона от 12 июня 2002 г. № 67-Ф3 «Об основных гарантиях избирательных прав и права на участие в референдуме граждан Российской Федерации». Законодателем предусмотрено, что если кандидат без вынуждающих к тому обстоятельств не сложил с себя полномочия, несовместимые со статусом депутата, выборного должностного лица, в результате чего назначены повторные выборы, этот кандидат должен полностью или частично возместить соответствующей избирательной комиссии произведенные ею расходы, связанные с проведением повторных выборов. Объем возмещения расходов зависит от усмотрения избирательной комиссии, что указывает на наличие коррупционного фактора. В целях устранения возможности выборочного правоприменения из комментируемой статьи предлагается исключить словосочетание «полностью или частично».

В Постановлении Правительства Российской Федерации от 26 февраля 2010 года № 96 следовало бы восстановить изъятые из прежней Методики антикоррупционной экспертизы коррупциогенные факторы, подлежащие учету в экспертной работе (отсутствие в акте положений о раскрытии информации о деятельности органов власти; отсутствие запретов, ограничений и мер ответственности для госслужащих; отсутствие возможности контроля, в том числе общественного, за действиями госорганов и должностных лиц; нормативные коллизии). Подобное дополнение порядка проведения антикоррупционной экспертизы нормативных правовых актов и их проектов, как представляется, послужит интересам реальной и действенной борьбы с коррупцией, в том числе и в электоральной сфере.

Необходимо предусмотреть юридическую ответственность за разработку и принятие должностными лицами органов государственной власти субъектов Российской Федерации, органов местного самоуправления 
нормативных правовых актов, противоречащих Конституции Российской Федерации, федеральным конституционным и федеральным законам, содержащих коррупционные нормы, повлекших за собой нарушения прав и свобод граждан, угрозу единству и территориальной целостности, обороноспособности государства, единству правового и экономического пространства. В связи с изложенным главу 30 УК РФ предлагается дополнить статьей 287.1 следующего содержания:

«Разработка и принятие нормативных правовых актов, противоречащих Конституции Российской Федерации, федеральным конституционным и федеральным законам, содержащих коррупционные нормы, повлекших установленные судом нарушения прав и свобод граждан, угрозу единству и территориальной целостности, обороноспособности государства, единству правового и экономического пространства

1. Разработка органами государственной власти, органами местного самоуправления, их должностными лицами проектов нормативных правовых актов, противоречащих Конституции Российской Федерации, федеральным конституционным и федеральным законам, содержащих коррупционные нормы,

наказывается штрафом в размере заработной платы или иного дохода осужденного за период от 6 месяцев до 1 года.

2. Принятие нормативных правовых актов, в отношении которых была проведена антикоррупционная экспертиза с заключением о наличии коррупционных норм, и повлекших установленные судом злоупотребление служебным положением, злоупотребление полномочиями, либо иное незаконное использование должностными лицами органов государственной власти или органов местного самоуправления своего должностного положения вопреки законным интересам общества и государства в целях получения выгоды в виде денег, ценностей, иного имущества или услуг 
имущественного характера, иных имущественных прав для себя или для третьих лиц,

наказывается лишением свободы на срок до двух лет с лишением права занимать определенные должности или заниматься определенной деятельностью на срок до трех лет.

3. Принятие нормативных правовых актов, в отношении которых была проведена правовая экспертиза с заключением о несоответствии Конституции Российской Федерации, федеральным конституционным и федеральным законам, и повлекших установленные судом нарушения прав и свобод граждан, угрозу единству и территориальной целостности, обороноспособности государства, единству правового и экономического пространства,

наказывается лишением свободы на срок до пяти лет с лишением права занимать определенные должности или заниматься определенной деятельностью на срок до трех лет».

Закрепление уголовно-правовой ответственности за разработку и принятие нормативных правовых актов, содержащих коррупционные нормы, проведение антикоррупционной экспертизы нормативных правовых актов и проектов таких актов позволит повысить качество законодательства и укрепить доверие населения к представительным органам власти и местного самоуправления.

Усилить ответственность политических партий, кандидатов в депутаты и изменить в лучшую сторону характер народного представительства можно было бы, вернувшись к практике исключения кандидатов из партийных списков за предоставление ими недостоверных сведений и подложных документов.

Часть 4 статьи 44 Федерального закона «О выборах депутатов Государственной Думы Федерального Собрания Российской Федерации» следовало бы дополнить пунктом 10 следующего содержания: «Центральная 
избирательная комиссия Российской Федерации исключает кандидата из федерального списка кандидатов в случае представления кандидатом подложных документов или заведомо ложных сведений при его включении в состав федерального списка кандидатов». Часть 9 статьи 91 данного Федерального закона нуждается в дополнении пунктом 6: «Регистрация кандидата, включенного в зарегистрированный федеральный список кандидатов, выдвинутый политической партией, может быть отменена Верховным Судом Российской Федерации по заявлению Центральной избирательной комиссии Российской Федерации, иной политической партии, федеральный список кандидатов которой зарегистрирован, в случаях: ... установления факта представления кандидатом подложных документов или заведомо ложных сведений».

В пункт 24 статьи 38 Федерального закона «Об основных гарантиях избирательных прав и права на участие в референдуме граждан Российской Федерации» представляется целесообразным включить подпункт «п», в котором в качестве основания отказа в регистрации кандидата предусмотреть представление кандидатом подложных документов или заведомо ложных сведений.

Аналогичное основание для исключения кандидата из заверенного списка кандидатов, а также для отмены регистрации кандидата судом по заявлению зарегистрировавшей кандидата избирательной комиссии, кандидата, зарегистрированного по тому же избирательному округу, можно было бы закрепить в подпункте «к» пункта 26 статьи 38 и подпункте «и» пункта 7 статьи 76 комментируемого Федерального закона.

Было бы логично исключить пункт 4 статьи 33 Федерального закона «Об основных гарантиях избирательных прав и права на участие в референдуме граждан Российской Федерации», который предусматривает возможность не представления кандидатами в депутаты представительных органов муниципальных образований в избирательные комиссии сведений о 
размере и об источниках доходов, а также об имуществе, принадлежащем кандидату на праве собственности, о вкладах в банках и ценных бумагах.

Правоохранительным органам должно быть предоставлено право осуществлять оперативно-розыскные мероприятия, следственные действия и привлекать к уголовной ответственности зарегистрированных кандидатов и должностных лиц, обоснованно подозреваемых в организованной преступной деятельности или в связях с преступными сообществами, независимо от их должностного положения и процессуального статуса. Для этого целесообразно ликвидировать существующие в УПК РФ и конституционно-правовом законодательстве иммунитеты от уголовного преследования (ч.8, 9 ст. 40 Федерального закона «Об общих принципах организации местного самоуправления в Российской Федерации», ч. 3, 6 и 7 ст. 16 Закона Российской Федерации «О статусе судей в Российской Федерации», ст. 39 Федерального закона «О Счетной палате Российской Федерации», п. 18 ст. 29 Федерального закона «Об основных гарантиях избирательных прав и права на участие в референдуме граждан Российской Федерации»).

Следует особо подчеркнуть потребность в модернизации оперативнорозыскного законодательства. Учитывая важность решаемых с помощью конфиденциальных источников задач по противодействию криминализации органов власти, в качестве дополнительной правовой гарантии их деятельности представляется необходимым дополнить 4.4 ст. 18 Федерального закона «Об оперативно-розыскной деятельности» положением следующего содержания: «Лицо, привлеченное к конфиденциальному сотрудничеству правоохранительным органом, освобождается от уголовной ответственности за деяние по поручению такого органа, если это деяние совершено с целью выявления, предупреждения и пресечения тяжких преступлений, при условии, что причиненный охраняемым интересам вред менее значителен, чем вред, который мог быть причинен в случае совершения предотвращенных преступлений, а также при условии, что 
выявление, предупреждение и пресечение преступной деятельности не могли быть осуществлены иным способом». В связи с этим предлагается дополнить главу 11 УК РФ «Освобождение от уголовной ответственности» статьей 77 в следующей редакции: «лицо, признанное в ходе следствия членом преступной организации (сообщества), и таким образом совершившее преступление средней тяжести или тяжкое преступление, может быть освобождено от уголовной ответственности, если оно до совершения преступного деяния заключило договор с правоохранительными органами и было внедрено в преступную организацию (сообщество), после чего всячески способствовало разоблачению членов преступной организации (сообщества), и в его действиях отсутствуют признаки совершения другого преступления».

Необходимо отменить положения ч.1 ст. 42 Закона Российской Федерации «О прокуратуре Российской Федерации», ч.1 ст. 29 Федерального закона «О Следственном комитете Российской Федерации», в соответствии с которыми проверка сообщения о факте правонарушения, совершенного прокурором (сотрудником Следственного комитета), является исключительной компетенцией органов прокуратуры (Следственного комитета). Данная норма устанавливает необоснованное исключение из общего порядка проверки правоохранительными органами сообщений о правонарушениях и дает потенциальные дискреционные полномочия должностным лицам органов прокуратуры (Следственного комитета) в интересах корпоративной солидарности и «защиты чести мундира».

Ликвидация (ограничение числа и содержания) иммунитетов зарегистрированных кандидатов, выборных должностных лиц и депутатской неприкосновенности потребует радикальной переработки главы 52 УПК РФ «Особенности производства по уголовным делам в отношении отдельных категорий лиц». В частности, из числа лиц, в отношении которых применяется особый порядок производства по уголовным делам, необходимо исключить: аудиторов Счетной палаты Российской Федерации; депутатов местного самоуправления; членов выборных органов местного 
самоуправления; выборных должностных лиц органов местного самоуправления; мировых судей; следователя; адвоката; зарегистрированного кандидата в депутаты законодательного (представительного) органа государственной власти субъекта Российской Федерации.

Формулировку «прокурор» в статье 447 УПК РФ предлагается заменить на «Генеральный прокурор Российской Федерации, его заместители, прокуроры субъектов Российской Федерации», формулировку «члены избирательных комиссий, комиссий референдума с правом решающего голоса» - на «Председатель ЦИК России, его заместители, председатели избирательных комиссий субъектов Российской Федерации».

Представляется, что реализация комплекса предложенных правовых мер является важной задачей государственного строительства и обеспечения преемственности антикриминальной политики в Российской Федерации. 


\section{ЗАКЛЮЧЕНИЕ}

1. В последние годы криминальные структуры занимают все более значимое место в российской политической системе. Представители организованной преступности стремятся контролировать прибыльные сектора экономики, управлять бюджетными средствами, участвовать в принятии решений органами власти, влиять на законотворческий процесс.

Решение криминалитетом данных задач осуществляется путем участия представителей организованной преступности в выборах с последующим избранием в органы власти и путем назначения своих ставленников на ключевые должности коррумпированными чиновниками государственного и муниципального аппаратов.

Приоритетным направлением является участие представителей криминалитета в избирательных кампаниях. Рост активности организованных преступных организаций (сообществ), связанный с попытками избрания в органы государственной власти и органы местного самоуправления, обусловлен заинтересованностью преступных организаций в постоянном наращивании своих доходов, прямой зависимостью официальной и теневой экономической деятельности от политической конъюнктуры в Российской Федерации, желанием руководителей и участников криминальных структур обеспечить личную безопасность.

Для представителей криминалитета избрание на выборную должность и получение депутатского мандата представляются исключительно значимыми.

Во-первых, факт наделения бандитов властными полномочиями легализует их криминальное прошлое и ставит под сомнение связи с преступными сообществами (организациями). 
Во-вторых, замещение выборных публичных должностей и принадлежность к органам народного представительства создают видимость реализации бандитами властных полномочий от имени и по поручению народа.

В-третьих, официальное задействование материальных, финансовых, информационных, юридических и иных ресурсов государства заметно расширяет сферы и силу воздействия преступных сообществ (организаций) на общественные процессы внутри страны и за ее пределами.

В настоящее время лидеры криминальных структур практически повсеместно легализовали свои преступные сообщества и аффилированные организации, что позволяет им объективно претендовать на роль самостоятельного элемента российской политической системы.

Роль преступных организаций (сообществ) в политической системе выражается в их функциях, к числу которых относятся:

а) представительство социально-политических интересов определенной части общества;

б) фактическое осуществление отдельных государственно-властных полномочий («теневая» юстиция, воспитание и трудоустройство подростков из неблагополучных семей и др.);

в) разработка и реализация политической стратегии и тактики борьбы за государственную власть в ходе выборов.

Проведенный в работе анализ места и роли преступных организаций (сообществ) в политической системе российского общества свидетельствует об институционализации и легализации криминальных структур в политической системе и исключительной общественной опасности подобного явления.

2. Стремление криминалитета к расширению сфер своего влияния отмечается как на федеральном, так и на региональном уровнях. Общественно-политическая значимость выборов депутатов Государственной Думы Федерального Собрания Российской Федерации подтверждается 
правоприменительной практикой избирательных комиссий и правоохранительных органов, которая демонстрирует активные попытки использования представителями организованной преступности данной избирательной кампании для проникновения в федеральный орган законодательной власти Российской Федерации.

Анализ биографических данных кандидатов, выдвинутых политическими партиями, принимавшими участие в выборах депутатов Государственной Думы Федерального Собрания Российской Федерации пятого и шестого созыва, сведений об их доходах и имуществе, неснятых и непогашенных судимостях, о привлечении к уголовной ответственности, об избрании в отношении некоторых из выдвинутых кандидатов меры пресечения в виде заключения под стражу, основаниях прекращения уголовного преследования данных лиц, указывает на следующие обстоятельства:

- в выдвинутых и зарегистрированных списках всех политических партий, принимавших участие в выборах депутатов Государственной Думы Федерального Собрания Российской Федерации, присутствовали кандидаты, привлекавшиеся к уголовной ответственности;

- среди лиц, имеющих погашенную судимость, на выборы в Государственную Думу Федерального Собрания Российской Федерации выдвигались и были зарегистрированы депутаты Государственной Думы Федерального Собрания Российской Федерации, депутаты законодательных органов государственной власти субъектов Российской Федерации, представительных органов муниципальных образований, председатели региональных и местных отделений партий, члены федеральных и региональных руководящих органов политических партий;

- некоторые кандидаты были осуждены по совокупности составов преступлений, отдельные лица имели неоднократные судимости, в т.ч. по тяжким составам; 
- в отношении ряда кандидатов проводилось предварительное следствие и избиралась мера пресечения в виде заключения под стражу;

- отдельные кандидаты находились в федеральном розыске.

Следует констатировать, что, несмотря на принимаемые избирательными комиссиями и правоохранительными органами меры, часть граждан, привлекавшихся к уголовной ответственности и имеющих погашенные судимости, была избрана депутатами Государственной Думы Федерального Собрания Российской Федерации.

3. Широкое информационное освещение федеральных избирательных кампаний, существенные материальные затраты политических партий и кандидатов, более строгий контроль за соблюдением законности и прозрачности избирательного процесса со стороны федеральных контролирующих и надзорных органов приводят к тому, что в современных условиях наиболее массовым каналом криминализации российской политической системы выступает участие представителей преступных организаций (сообществ) в муниципальных и региональных выборах.

Практика региональных и муниципальных выборов, прошедших в 20062013 гг,, свидетельствует о некоторых тенденциях участия организованных преступных групп в избирательных кампаниях.

Во-первых, в настоящее время заметно снизилось число представителей организованных преступных групп, непосредственно баллотирующихся в депутаты или на выборные должности. Лидеры уголовной среды предлагают перспективным кандидатам свое участие в финансировании избирательной кампании либо самостоятельно заблаговременно готовят для внедрения в органы государственной власти и местного самоуправления своих «незасвеченных» ставленников (нередко близких родственников), не имеющих судимостей, не скомпрометировавших себя выявленными связями с организованными преступными группами.

Во-вторых, несмотря на легализацию статуса и доходов, никто из депутатов или выборных должностных лиц, являющихся лидерами уголовной 
среды, не распустил свои боевые группировки («боевиков»). Как правило, эти структуры действуют под прикрытием частных охранных предприятий или служб безопасности. Таким образом, в ходе организации и проведения выборов у представителей организованных преступных групп сохраняется возможность использовать силовое воздействие на избирательный процесс для оказания влияния на принятие политических решений, дестабилизации обстановки и устрашения населения. Кроме того, лидеры этнических преступных групп, действующих на территории Российской Федерации, могут использовать свои боевые подразделения в ходе межнациональных столкновений, периодически возникающих в отдельных субъектах Российской Федерации.

В-третьих, с учетом повышения роли политических партий в избирательном процессе важнейшей задачей уголовной разведки и контрразведки стало установление контроля организованных преступных групп над ведущими политическими партиями (региональными отделениями политических партий) и продвижение своих представителей в органы государственной власти, местного самоуправления и избирательные комиссии с использованием партийных структур.

B-четвертых, представителями организованных преступных групп практически перестало осуществляться отмывание денежных средств в ходе выборов. Данное обстоятельство обусловлено наличием у организованных преступных групп многообразных законных источников финансирования избирательных кампаний и ужесточением юридической ответственности за нарушение порядка финансирования выборов.

Указанные тенденции участия организованных преступных групп в избирательных кампаниях затрудняют целенаправленную деятельность правоохранительных органов по недопущению представителей криминалитета в органы государственной власти и местного самоуправления в ходе выборов и усиливают общественную опасность подобных процессов.

Проведенный анализ списков зарегистрированных кандидатов на муниципальных и региональных выборах, состоявшихся в период с 2006 по 
2013 гг., свидетельствует о том, что среди ранее судимых кандидатов на выборах значительную долю составляют лица, осужденные за преступления против собственности. Данная категория граждан баллотируется как в порядке самовыдвижения, так и в составе партийных списков.

В списках кандидатов от партий также наблюдается существенное криминальное представительство граждан, имеющих судимость за преступления против общественной безопасности, преступления против жизни и здоровья, преступления против государственной власти, интересов государственной службы и службы в органах местного самоуправления, преступления в сфере экономической деятельности и за преступления против порядка управления.

Некоторые кандидаты были осуждены по совокупности составов преступлений, отдельные лица находились в федеральном розыске.

В ряде случаев кандидаты в депутаты и на выборные должности имели неоднократные судимости.

Для проникновения в органы государственной власти субъектов Российской Федерации и органы местного самоуправления представители криминалитета используют разнообразные ухищрения.

С целью получения депутатских мандатов в федеральном и региональных органах законодательной власти криминальные элементы сознательно искажают свои установочные данные (отчество, дату рождения), удаляют сведения о себе из региональных баз правоохранительных органов, а также стремятся продвигать «незасвеченных» ставленников (нередко близких родственников), не имеющих судимостей и выявленных связей с организованной преступностью. Это затрудняет проверки указанных граждан по учетам ФГБУ «ГИАЦ МВД России» и информационных центров территориальных органов МВД России и дает им возможность избираться в органы государственной власти.

Некоторые ранее судимые кандидаты баллотируются в составе региональных групп субъектов Российской Федерации, где они не проживали 
и к которым не имеют никакого отношения. Часть кандидатов меняет партийную принадлежность и баллотируется в списках другой партии. Указание в качестве рода занятий «временно неработающий» в ряде случаев используется кандидатами, в отношении которых избрана мера пресечения в виде заключения под стражу (ст. 98 УПК РФ).

4. Головным субъектом противодействия криминализации органов публичной власти в условиях выборных кампаний являются избирательные комиссии.

Можно выделить ряд взаимосвязанных организационных форм антикриминальной деятельности избирательных комиссий в условиях избирательных кампаний:

- проверка достоверности представленных кандидатами сведений о неснятых (непогашенных) судимостях, судимостях за совершение тяжких и (или) особо тяжких преступлений;

- проверка достоверности представленных кандидатами сведений о доходах и имуществе, о вкладах в банках и ценных бумагах, сведений о счетах (вкладах), наличных денежных средствах и ценностях в иностранных банках, расположенных за пределами территории Российской Федерации;

- обращение в правоохранительные органы с запросами: о лицах, подозреваемых или обвиняемых в совершении преступления; о лицах, осужденных за совершение преступления; о лицах, в отношении которых вынесено постановление о прекращении уголовного преследования за истечением срока давности, в связи с примирением сторон, вследствие акта об амнистии, в связи с деятельным раскаянием; о лицах, в отношении которых до вступления приговора в законную силу был применен акт помилования или акт об амнистии, освобождающие от наказания; о лицах, совершивших административное правонарушение; о лицах, состоящих на профилактическом учете; о лицах, объявленных в розыск; о проверке связей кандидатов с представителями криминалитета, подконтрольными криминальным структурам организациями и кредитными учреждениями; 
- исключение кандидата (группы кандидатов) из заверенных списков;

- отказ в регистрации кандидата (списков кандидатов);

- аннулирование регистрации кандидата (списка кандидатов) вышестоящей комиссией;

- обращение в суд с представлением об отмене регистрации кандидата (списка кандидатов);

- контроль за источниками поступления, правильным учетом и использованием денежных средств избирательных фондов;

- проверка финансовых отчетов кандидатов;

- проведение антикоррупционной экспертизы нормативных актов избирательных комиссий;

- информирование правоохранительных органов и спецслужб для проверки сигналов, пресечения противоправной агитационной деятельности, производства по делам об административных правонарушениях или предварительного расследования;

- производство по делам об административных правонарушениях в сфере выборов, отнесенных к компетенции членов избирательных комиссий с правом решающего голоса.

Антикриминальная деятельность избирательных комиссий является элементом общегосударственной стратегии противодействия криминализации органов власти, которую осуществляют не только спецслужбы и правоохранительные органы, но и органы власти, управления, СМИ, политические партии, муниципальные и правозащитные структуры гражданского общества.

Сложившаяся в политической и социально-экономической системах криминогенная ситуация требует реагирования со стороны руководства государства, формирования и последовательной реализации более жесткой антикриминальной политики в Российской Федерации.

Противодействие дальнейшему проникновению преступных организаций (сообществ) в органы власти и их сращиванию с другими 
институтами политической системы российского общества предполагает незамедлительную и планомерную работу в рамках следующих основных направлений:

тесная координация деятельности правоохранительных органов, СМИ, политических партий и общественных организаций по недопущению партийной коррупции и избрания (назначения) представителей криминалитета в органы государственной власти и местного самоуправления;

подрыв экономической базы преступных сообществ, вытеснение представителей криминалитета из легального бизнеса;

формирование негативного отношения населения к деятельности преступных сообществ, криминальным лидерам и популяризация антикриминальных мер;

совершенствование законодательства о выборах, государственной и муниципальной службе путем установления правовых ограничений на избрание (назначение на должности) в органы государственной власти и местного самоуправления лиц, находящихся под следствием, в розыске, имеющих судимость за совершение тяжких или особо тяжких преступлений ${ }^{1}$, а также граждан, в отношении которых уголовное преследование прекращено за истечением срока давности, в связи с примирением сторон, вследствие акта об амнистии или в связи с деятельным раскаянием;

усиление требований к замещению государственных должностей Российской Федерации, государственных должностей субъектов Российской Федерации, должностей гражданской, военной, правоохранительной и муниципальной службы;

введение обязательных антикриминальных проверок всех кандидатов, поступающих на гражданскую, военную, правоохранительную и муниципальную службу;

1 Данное требование реализовано в отношении кандидатов в депутаты и на выборные должности. 
расширение перечня должностных лиц, представляющих сведения о своих доходах, расходах, об имуществе и обязательствах имущественного характера, а также о доходах, расходах, имуществе и обязательствах имущественного характера своих супруги (супруга) и несовершеннолетних детей; уточнение требований о расходах указанных должностных лиц;

регулярное проведение антикоррупционных (антикриминальных) расследований;

совершенствование методики антикоррупционной экспертизы нормативных правовых актов;

ликвидация (ограничение числа и содержания) иммунитетов выборных должностных лиц и депутатской неприкосновенности;

расширение перечня оснований исключения кандидатов из заверенного списка, а также отказа кандидату в регистрации и отмены регистрации кандидата судом в связи с представлением подложных документов или заведомо ложных сведений.

5. Перечисленные направления противодействия криминализации органов публичной власти в Российской Федерации необходимо выстраивать с учетом существующих международно-правовых основ и зарубежного опыта.

Противодействие криминализации органов публичной власти в зарубежных странах осуществляется с использованием гласных и негласных средств, форм и методов работы.

Стратегическими направлениями противодействия криминализации органов публичной власти в зарубежных странах, как правило, выступают:

- антикриминальные проверки кандидатов на государственную службу и работу в правоохранительных органах (в т.ч. с использованием полиграфа $)^{1}$;

${ }^{1}$ К сожалению, в последние годы в правоохранительных органах и спецслужбах Российской Федерации следует констатировать распространение негативной практики т.н. «заказного полиграфа». В ходе такого обследования при поступлении на службу и назначении на руководящие должности неугодные руководству кандидаты (сотрудники) 
- контроль контрразведывательных органов за процедурами назначения на «ответственные» должности в государственном аппарате и правоохранительных структурах;

- ужесточение наказаний за преступления, совершенные в составе преступных организаций (сообществ);

- нарушение организационных структур преступных группировок путем привлечения к уголовной ответственности их лидеров, что позволяет более эффективно проводить разложенческую работу среди рядовых членов организованных преступных групп, добиваться их распада и, в конечном счете, ликвидации преступного формирования;

- подрыв финансовой базы преступной организации путем перекрытия каналов ее преступных доходов, а также изъятия незаконно добытых капиталов, в частности, при активном использовании конфискационных мер и налогового законодательства;

- реализация программ защиты свидетелей по делам о коррупции и организованной преступности;

- проведение специализированных тайных операций в отношении преступных сообществ (организаций);

- устранение причин и условий, способствующих существованию и функционированию преступной организации, в том числе путем проведения социально-экономических мероприятий по сокращению резервной армии организованной преступности и «сдерживания политиков, прибегающих к услугам преступных формирований».

Проведенный в работе анализ международно-правовых основ и зарубежного опыта противодействия криминализации органов публичной власти свидетельствует о наличии эффективных правовых и

отстраняются от назначения, а «проплаченные» и зависимые (контролируемые подразделениями кадров или собственной безопасности) соискатели назначаются на должности. Инквизиционный обвинительный уклон, отсутствие каких-либо гарантий защиты чести и доброго имени, непрозрачность процедуры проведения, невозможность ознакомления и оспаривания результатов в значительной степени снижают антикриминальный потенциал и значимость данного мероприятия. 
организационных механизмов, позволяющих предотвращать назначение и избрание на «ответственные» должности представителей криминалитета, раскрывать и расследовать коррупционные схемы в партийных структурах и государственном аппарате, привлекать лидеров и участников преступных организаций (сообществ) к уголовной ответственности. С учетом российской специфики те или иные элементы международной и зарубежной правотворческой и правоприменительной практики могут быть использованы отечественным законодателем при совершенствовании правовой базы противодействия криминализации органов публичной власти.

6. Эффективность реализации антикриминальных мероприятий непосредственно связана с качеством законодательных актов, регулирующих соответствующие общественные отношения.

В контексте модернизации правовой базы минимально необходимым средством борьбы с криминализацией органов публичной власти представляется сделать обязательность указания кандидатами в депутаты и (или) на выборные должности всех имеющихся судимостей (в т.ч. снятых и погашенных).

Качество законодательного противодействия криминализации выборных органов власти можно было бы повысить путем дополнения пункта 3.2 статьи 4 Федерального закона «Об основных гарантиях избирательных прав и права на участие в референдуме граждан Российской Федерации» подпунктом «д» - «осужденные за совершение преступлений, предусмотренных статьями 141, 141.1, 142, 142.1 Уголовного кодекса Российской Федерации» ${ }^{1}$. Аналогичные правовые положения следует включить в часть 4.2 статьи 5 Федерального закона «О выборах депутатов Государственной Думы Федерального Собрания Российской Федерации» и пункт 5.2 статьи 3 Федерального закона «О выборах Президента Российской

1 Данное предложение приобретет актуальность, если не будут реализованы сформулированные автором меры по ограничению пассивного избирательного права в связи с прекращением уголовного преследования за истечением срока давности, в связи с примирением сторон, вследствие акта об амнистии, в связи с деятельным раскаянием. 
Федерации». Таким образом, лица, имеющие судимость по делам, связанным с нарушением законодательства о выборах и референдумах, не смогут избираться в органы государственной власти и органы местного самоуправления.

Учитывая взаимосвязанные положения пункта 1 статьи 4 Закона Российской Федерации «О статусе судей в Российской Федерации», пункта 2 статьи 40.1 Закона Российской Федерации «О прокуратуре Российской Федерации», пунктов 2 и 3 части 1 статьи 29 Федерального закона «О полиции», подпункта 4 пункта 5 статьи 18 Федерального закона «О государственной охране», пункта «в» части 3 статьи 16 Федерального закона «О федеральной службе безопасности», пункта 2 части 4 статьи 16 Федерального закона «О Следственном комитете Российской Федерации», устанавливающие ограничения на службу или на работу в судейском корпусе, органах прокуратуры, полиции, органах государственной охраны, федеральной службы безопасности, следственных органах лиц, в отношении которых уголовное преследование прекращено за истечением срока давности, в связи с примирением сторон, вследствие акта об амнистии или в связи с деятельным раскаянием, данные правовые нормы об ограничении правосубъектности граждан (в нашем случае - пассивного избирательного права) представляется логичным закрепить и в федеральных законах о выборах.

Действующие антикоррупционные законы содержат различные подходы к оценке материального положения, источников доходов, законности и прозрачности расходов отдельных должностных лиц и правовым последствиям конфликта интересов у данных лиц, непредставления этими должностными лицами сведений о доходах, расходах, имуществе и обязательствах имущественного характера в установленные сроки, а также представления заведомо недостоверных или неполных сведений. 
Для того, чтобы антикоррупционная и антикриминальная политика проводилась эффективно, необходимо установить единые правовые ограничения и запреты в отношении государственных и муниципальных служащих, лиц, замещающих государственные должности Российской Федерации, государственные должности субъектов Российской Федерации, должности глав муниципальных образований, муниципальные должности.

В этой связи в перечень оснований освобождения от должности (досрочного прекращения полномочий) в статьях 9-11 Федерального конституционного закона «О Правительстве Российской Федерации», части 1 статьи 4 Федерального закона «О статусе члена Совета Федерации и статусе депутата Государственной Думы Федерального Собрания Российской Федерации», части 8 статьи 7, части 8 статьи 8 и части 10 статьи 9 Федерального закона «О Счетной палате Российской Федерации», статье 19 Федерального закона «Об общих принципах организации законодательных (представительных) и исполнительных органов государственной власти субъектов Российской Федерации», пункте 8 статьи 29 Федерального закона «Об основных гарантиях избирательных прав и права на участие в референдуме граждан Российской Федерации», пункте 5 статьи 8.1 Закона Российской Федерации «О статусе судей в Российской Федерации» предлагается включить:

- непредставление сведений о своих доходах, расходах, об имуществе и обязательствах имущественного характера, а также о доходах, расходах, имуществе и обязательствах имущественного характера своих супруги (супруга) и несовершеннолетних детей либо представление заведомо недостоверных или неполных сведений;

- приобретение зарегистрированного за пределами Российской Федерации права собственности на имущество.

Таким образом, курсу на проведение единой политики противодействия коррупции в Российской Федерации будет соответствовать унификация ограничений, запретов и обязанностей государственных и 
муниципальных служащих, лиц, замещающих государственные должности Российской Федерации, государственные должности субъектов Российской Федерации, должности глав муниципальных образований, муниципальные должности.

Претенденты на замещение государственных должностей Российской Федерации, государственных должностей субъектов Российской Федерации, должностей гражданской, военной, правоохранительной и муниципальной службы должны, как представляется, проходить обязательную антикриминальную проверку по оперативно-справочным учетам и автоматизированным информационным системам органов внутренних дел и безопасности.

С целью действительного подрыва экономической базы преступных сообществ, а не имитации борьбы с преступностью, конфискация имущества должна быть возвращена в разряд видов уголовного наказания. При этом перечень преступлений, за совершение которых возможно применение конфискации, нуждается в дополнении составами, результатом совершения которых становится получение имущественной выгоды.

Правовой режим блокирования (замораживания) денежных средств или иного имущества организаций и физических лиц должен быть распространен на любые доходы, полученные преступным путем, а не только на имущество организаций и граждан, подозреваемых в причастности к экстремистской деятельности или терроризму.

Необходимо отменить положения ч.1 ст. 42 Закона Российской Федерации «О прокуратуре Российской Федерации», ч.1 ст. 29 Федерального закона «О Следственном комитете Российской Федерации», в соответствии с которыми проверка сообщения о факте правонарушения, совершенного прокурором (сотрудником Следственного комитета), является исключительной компетенцией органов прокуратуры (Следственного комитета). Данная норма устанавливает необоснованное исключение из общего порядка проверки правоохранительными органами сообщений о 
правонарушениях и дает потенциальные дискреционные полномочия должностным лицам органов прокуратуры (Следственного комитета) в интересах корпоративной солидарности и «защиты чести мундира».

Повысить ответственность политических партий, кандидатов в депутаты и улучшить качество народного представительства можно было бы, вернувшись к практике исключения кандидатов из партийных списков за предоставление ими недостоверных сведений и подложных документов. Представление кандидатом подложных документов или заведомо ложных сведений следовало бы закрепить в качестве основания отказа в регистрации.

Нуждается в отмене коррупциогенное положение избирательного законодательства, предусматривающее возможность непредставления кандидатами в депутаты представительных органов муниципальных образований в избирательные комиссии сведений о размере и об источниках доходов, а также об имуществе, принадлежащем кандидату на праве собственности, о вкладах в банках и ценных бумагах.

Правоохранительным органам должно быть предоставлено право осуществлять оперативно-розыскные мероприятия, следственные действия и привлекать к уголовной ответственности зарегистрированных кандидатов и должностных лиц, обоснованно подозреваемых в организованной преступной деятельности или в связях с преступными сообществами, независимо от их должностного положения и процессуального статуса. Для этого целесообразно ликвидировать существующие в главе 52 УПК РФ и конституционно-правовом законодательстве иммунитеты от уголовного преследования (ч.8, 9 ст. 40 Федерального закона «Об общих принципах организации местного самоуправления в Российской Федерации», ч. 3, 6 и 7 ст. 16 Закона Российской Федерации «О статусе судей в Российской Федерации», ст. 39 Федерального закона «О Счетной палате Российской Федерации», п. 18 ст. 29 Федерального закона «Об основных гарантиях избирательных прав и права на участие в референдуме граждан Российской Федерации»). В частности, из числа лиц, в отношении которых применяется 
особый порядок производства по уголовным делам, необходимо исключить: аудиторов Счетной палаты Российской Федерации; депутатов местного самоуправления; членов выборных органов местного самоуправления; выборных должностных лиц органов местного самоуправления; мировых судей; следователя; адвоката; зарегистрированного кандидата в депутаты законодательного (представительного) органа государственной власти субъекта Российской Федерации.

Представляется, что реализация комплекса предложенных правовых мер является важной задачей государственного строительства и обеспечения последовательности антикриминальной политики в Российской Федерации. 


\section{СПИСОК ИСПОЛЬЗОВАННЫХ ИСТОЧНИКОВ И ЛИТЕРАТУРЫ}

1. Конституция Российской Федерации (с учетом поправок, внесенных законами Российской Федерации о поправках к Конституции Российской Федерации от 30 декабря 2008 г. № 6-ФКЗ и от 30 декабря 2008 г. № 7-ФКЗ) // Рос. газ. 1993. 25 декабря; 2009. 21 января.

\section{Постановления и Определения Конституционного Суда Российской Федерачии}

2. Постановление Конституционного Суда Российской Федерации от 12 апреля 2002 года № 9-П «По делу о проверке конституционности положений статей 13 и 14 Федерального закона «Об общих принципах организации законодательных (представительных) и исполнительных органов государственной власти субъектов Российской Федерации» в связи с жалобой гражданина А.П. Быкова, а также запросами Верховного Суда Российской Федерации и Законодательного Собрания Красноярского края» // Рос. газ. 2002. 25 апреля.

3. Постановление Конституционного Суда Российской Федерации от 19 марта 2003 г. № 3-П «По делу о проверке конституционности положений Уголовного кодекса Российской Федерации, регламентирующих правовые последствия судимости лица, неоднократности и рецидива преступлений, а также пунктов 1-8 постановления Государственной Думы Федерального Собрания Российской Федерации от 26 мая 2000 г. «Об объявлении амнистии в связи с 55-летием Победы в Великой Отечественной Войне 1941-1945 годов» в связи с запросом Останкинского межмуниципального (районного) суда города Москвы и жалобами ряда граждан» // Рос. Газ. 2003. 2 апреля.

4. Постановление Конституционного Суда Российской Федерации от 9 июня 2011 г. № 12-П «По делу о проверке конституционности положений пункта 7 статьи 16 Закона Российской Федерации «О статусе судей в Российской Федерации» и части 1 статьи 9 Федерального закона «Об оперативно-розыскной деятельности» в связи с жалобой гражданина И.В Аносова» // Рос. газ. 2011. 22 июня.

5. Постановление Конституционного Суда Российской Федерации от 27 июня 2013 г. № 15-П «По делу о проверке конституционности положений частей 3 и 10 статьи 40 Федерального закона «Об общих принципах организации местного самоуправления в Российской Федерации» и пункта 3 части первой статьи 83 Трудового кодекса Российской Федерации в связи с жалобой гражданина А.В. Дубкова» // Рос. газ. 2013. 12 июля.

6. Постановление Конституционного Суда Российской Федерации от 10 октября 2013 г. № 20-П «По делу о проверке конституционности подпункта «а» пункта 3.2 статьи 4 Федерального закона «об основных гарантиях избирательных прав и права на участие в референдуме граждан Российской Федерации», части первой статьи 10 и части 6 статьи 86 УК РФ в связи с жалобами граждан Г.Б.ЕГорова, А.Л.Казакова, И.Ю.Кравцова, А.В. Куприянова, А.С. Латыпова и В.Ю. Синькова» // Рос. газ. 2013. 23 октября.

7. Определение Конституционного Суда Российской Федерации от 12 мая 2003 г. № 168-О «Об отказе в принятии к рассмотрению жалобы гражданина Быкова А.П. на нарушение его конституционных прав положениями подпункта «в» пункта 3 статьи 35 Устава Красноярского края и 
подпункта «в» пункта 1 статьи 4 Закона Красноярского края «О статусе депутата Законодательного собрания Красноярского края» / Избирательное право и избирательный процесс в решениях Конституционного Суда Российской Федерации. 2000-2007. Т. 1. М.: ЦИК России, 2008. С. 380-383.

8. Определение Конституционного Суда Российской Федерации от 6 июня 2003 г. № 185-О «Об отказе в принятии к рассмотрению жалобы гражданина Климентьева А.А. на нарушение его конституционных прав положениями пункта 10 статьи 32 и пункта 1 статьи 64 Федерального закона от 19 сентября 1997 г. «Об основных гарантиях избирательных прав и права на участие в референдуме граждан Российской Федерации», пункта 2 статьи 67 Закона Нижегородской области от 4 июня 2002 г. «О выборах глав местного самоуправления в Нижегородской области» и статьи 211 Гражданского процессуального кодекса РСФСР»/ Избирательное право и избирательный процесс в решениях Конституционного Суда Российской Федерации. 2000-2007. Т. 1. М.: ЦИК России, 2008. С. 394-398.

9. Определение Конституционного Суда Российской Федерации от 11 июля 2007 г. № 406-О «По жалобе гражданина Груздева А.А. на нарушение его конституционных прав статьей 79 Уголовного кодекса Российской Федерации и частью 3 статьи 399 Уголовно-процессуального кодекса Российской Федерации» // Вестник Конституционного Суда Российской Федерации. 2007. № 1.

10. Определение Конституционного Суда Российской Федерации от 2 апреля 2009 г. № 483-О-П «По жалобе гражданина Цыганкова Бориса Викторовича на нарушение его конституционных прав пунктом 2 статьи 48 Федерального закона «О воинской обязанности и военной службе» и пунктом 1 статьи 25 Положения о порядке прохождения военной службы» // Вестник Конституционного Суда Российской Федерации. 2007. № 1.

11. Определение Конституционного Суда Российской Федерации от 1 октября 2009 г. № 1053-О-О «Об отказе в принятии к рассмотрению жалобы гражданина Байкова А.А. на нарушение его конституционных прав статьей 395 Уголовно-процессуального кодекса Российской Федерации, статьей 18 Федерального закона «О содержании под стражей подозреваемых и обвиняемых в совершении преступлений», статьей 4 Федерального закона «Об основных гарантиях избирательных прав и права на участие в референдуме граждан Российской Федерации», статьей 5 Федерального закона «О выборах депутатов Государственной Думы Федерального Собрания Российской Федерации» и пунктом 4 статьи 3 Федерального закона «О выборах Президента Российской Федерации».

\section{Международные акты}

12. Декларация о критериях свободных и справедливых выборов (Париж, 26 марта 1994 г.) (По документам Межпарламентского Союза) М.: Известия, 1994. $11 \mathrm{c}$.

13. Резолюция 1264 (2001) Парламентской Ассамблеи Совета Европы «О кодексе надлежащей практики в избирательных вопросах» (Страсбург, 8 ноября 2001 г.) // Международные избирательные стандарты. Сб. документов // Отв. ред.: кандидат юрид. наук А.А. Вешняков; науч. ред.: доктор юрид. наук В.И. Лысенко. М.: Издательство Весь Мир, 2004. С. 593-594.

14. Рекомендация от 8 апреля 2003 г. № Rec (2003) 4 Комитета Министров Совета Европы «Об общих принципах борьбы с коррупцией при финансировании политических партий и избирательных кампаний» // Международные избирательные стандарты. Сб. документов // Отв. ред.: доктор юрид. наук В.И. Лысенко. М.: ЦИК России, 2009. С. 380-384.

15. Рекомендация 1595 (2003) Парламентской Ассамблеи Совета Европы «О Своде рекомендуемых норм при проведении выборов» (Страсбург, 30 января 
2003 г.) // Международные избирательные стандарты. Сб. документов // Отв. ред.: доктор юрид. наук В.И. Лысенко. М.: ЦИК России, 2009. С. 320.

16. Конвенция о стандартах демократических выборов, избирательных прав и свобод в государствах-участниках Содружества Независимых Государств // Вестник ЦИК Российской Федерации. 2002. № 11. С. 218-231.

\section{Нормативные правовые акты федеральных органов государственной власти}

\section{Федеральные законьл}

17. Федеральный закон от 3 апреля 1995 г. № 40-Ф3 «О федеральной службе безопасности» // Рос. газ. 1995. 12 апреля.

18. Федеральный закон от 20 апреля 1995 года № 45-Ф3 (с изм. и доп.) «О государственной защите судей, должностных лиц правоохранительных и контролирующих органов» // Рос. газ. 1995. 26 апреля.

19. Федеральный закон от 13 июня 1996 г. (в ред. от 4 мая 2011 г.) № 63Ф3 «Уголовный кодекс Российской Федерации» // С3 РФ. 1996. № 25. СТ. 2954.

20. Федеральный закон от 28 марта 1998 г. № 53-Ф3 «О воинской обязанности и военной службе» // СЗ РФ. 1998. № 13. Ст. 1475.

21. Федеральный закон от 27 мая 1998 г. № 76-Ф3 «О статусе военнослужащих» // СЗ РФ. 1998. № 22. Ст. 2331.

22. Федеральный закон от 6 октября 1999 г. (в ред. от 28 декабря 2010 г.) № 184-Ф3 «Об общих принципах организации законодательных (представительных) и исполнительных органов государственной власти субъектов Российской Федерации» // СЗ РФ. 1999. № 42. Ст. 5005.

23. Федеральный закон от 11 июля 2001 г. (в ред. от 5 апреля 2011 г.) № 95-Ф3 «О политических партиях» // СЗ РФ. 2001. № 29. Ст. 2950.

24. Федеральный закон от 7 августа 2001 г. № 115-Ф3 «О противодействии легализации (отмыванию) доходов, полученных преступным путем, и финансированию терроризма // Рос. газ. 2001. 9 августа.

25. Федеральный закон от 30 декабря 2001 г. (в ред. от 4 мая 2011 г.) № 195-Ф3 «Кодекс Российской Федерации об административных правонарушениях» // Рос. газ. 2001. 31 декабря.

26. Федеральный закон от 12 июня 2002 г. (в ред. от 20 марта 2011 г.) № 67-Ф3 «Об основных гарантиях избирательных прав и права на участие в референдуме граждан Российской Федерации» // Рос. газ. 2002. 15 июня.

27. Федеральный закон от 10 января 2003 г. (в ред. от 28 декабря 2010 г.) № 19-Ф3 «О выборах Президента Российской Федерации»// Рос. газ. 2003. 16 января.

28. Федеральный закон от 6 октября 2003 г. № 131-Ф3 «Об общих принципах организации местного самоуправления в Российской Федерации».

29. Федеральный закон от 27 июля 2004 г. № 79-Ф3 «О государственной гражданской службе Российской Федерации» // С3 РФ. 2004. № 31 . Ст. 3215.

30. Федеральный закон от 20 августа 2004 года № 119-Ф3 «О государственной защите потерпевших, свидетелей и иных участников уголовного судопроизводства» // Рос. газ. 2004. 25 августа. 
31. Федеральный закон от 18 мая 2005 г. (в ред. от 23 февраля 2011 г.) № 51-Ф3 «О выборах депутатов Государственной Думы Федерального Собрания Российской Федерации» // Рос. газ. 2005. 24 мая.

32. Федеральный закон от 2 марта 2007 г. № 25-Ф3 «О муниципальной службе в Российской Федерации» // СЗ РФ. 2007. № 10. Ст. 1152.

33. Федеральный закон от 25 декабря 2008 г. № 273-Ф3 «О противодействии коррупции» // Рос. газ. 2008. 30 декабря.

34. Федеральный закон от 28 декабря 2010 г. № 403-Ф3 «О Следственном комитете Российской Федерации» // Рос. газ. 2010. 30 декабря.

35. Федеральный закон от 7 февраля 2011 г. № 3-Ф3 «О полиции» // С3 РФ. 2011. № 7. Ст. 900.

36. Федеральный закон от 3 декабря 2012 г. № 230-Ф3 «О контроле за соответствием расходов лиц, замещающих государственные должности, и иных лиц их доходам» // Рос. газ. 2012. 5 декабря.

37. Федеральный закон от 25 декабря 2012 г. № 244-Ф3 «О ратификации Договора о противодействии легализации (отмыванию) доходов, полученных преступным путем, и финансированию терроризма при перемещении наличных денежных средств и (или) денежных инструментов через таможенную границу Таможенного союза» // Рос. газ. 2012. 28 декабря.

38. Федеральный закон от 5 апреля 2013 г. № 41-Ф3 «О Счетной палате Российской Федерации» // Рос. газ. 2013. 10 апреля.

39. Федеральный закон от 7 мая 2013 г. № 79-Ф3 «О запрете отдельным категориям лиц открывать и иметь счета (вклады), хранить наличные денежные средства и ценности в иностранных банках, расположенных за пределами территории Российской Федерации, владеть и (или) пользоваться иностранными финансовыми институтами» // СЗ РФ. 2013. № 19, ст. 2306.

\section{Законь Российской Федеращии}

40. Закон Российской Федерации от 17 января 1992 г. (в ред. от 7 февраля 2011 г.) № 2202-1 «О прокуратуре Российской Федерации» // Рос. газ. 1992. 18 февраля.

41. Закон Российской Федерации от 26 июня 1992 г. № 3132-1 «О статусе судей в Российской Федерации» // Рос. газ. 1992. 29 июля.

\section{Постановления Государственной Думь Федерального Собрания Российской Федерачии}

42. Постановление Государственной Думы Федерального Собрания Российской Федерации от 16 апреля 1998 г. № 2394-II ГД «О создании Комиссии Государственной Думы Федерального Собрания Российской Федерации по проверке соблюдения избирательного законодательства в ходе подготовки и проведения выборов мэра города Нижнего Новгорода» // С3 РФ. 1998. № 17. Ст. 1897.

43. Постановление Государственной Думы Федерального Собрания Российской Федерации от 23 октября 2002 г. № 33170-ІІІ ГД «О комиссии Государственной Думы Федерального Собрания Российской Федерации по изучению подготовки и проведения выборов депутатов Законодательного Собрания города Санкт-Петербурга» // С3 РФ. 2002. № 44. Ст. 4334. 


\section{Указы Президента Российской Федерачии и Постановления Правительства Российской Федерачии}

44. Указ Президента Российской Федерации от 12 мая 2009 г. № 537 «Об утверждении Стратегии национальной безопасности Российской Федерации до 2020 года» // Рос. газ. 2009. 19 мая.

45. Указ Президента Российской Федерации от 18 мая 2009 г. № 558 «О представлении гражданами, претендующими на замещение государственных должностей Российской Федерации, и лицами, замещающими государственные должности Российской Федерации, сведений о доходах, об имуществе и обязательствах имущественного характера» // Рос. газ. 2009. 20 мая.

46. Указ Президента Российской Федерации от 18 мая 2009 г. № 559 «О представлении гражданами, претендующими на замещение должностей федеральной государственной службы, и федеральными государственными служащими сведений о доходах, об имуществе и обязательствах имущественного характера» // Рос. газ. 2009. 20 мая.

47. Указ Президента Российской Федерации от 13 апреля 2010 г. № 460 «О Национальной стратегии противодействия коррупции и Национальном плане противодействия коррупции на 2010-2011 годы»// Рос. газ. 2010. 15 апреля.

48. Указ Президента Российской Федерации от 13 марта 2012 г. № 297 «О Национальном плане противодействия коррупции на 2012-2013 годы и внесении изменений в некоторые акты Президента Российской Федерации по вопросам противодействия коррупции» // СЗ РФ. 2012. № 12. Ст. 1391.

49. Указ Президента Российской Федерации от 2 апреля 2013 г. № 309 «О мерах по реализации отдельных положений Федерального закона «О противодействии коррупции»"» // Рос. газ. 2013. 4 апреля.

50. Указ Президента Российской Федерации от 6 июня 2013 г. № 546 «O проверке достоверности сведений об имуществе и обязательствах имущественного характера за пределами территории Российской Федерации, o расходах по каждой сделке по приобретению объектов недвижимости, транспортных средств, ценных бумаг и акций, представляемых кандидатами на выборах в органы государственной власти, выборах глав муниципальных районов и глав городских округов, а также политическими партиями в связи с внесением Президенту Российской Федерации предложений о кандидатурах на должность высшего должностного лица (руководителя высшего исполнительного органа государственной власти) субъекта Российской Федерации» // Рос. газ. 2013. 11 июня.

51. Постановление Правительства Российской Федерации от 25 августа 1999 г. № 937 «О содействии избирательным комиссиям в организации подготовки и проведения выборов депутатов Государственной Думы Федерального Собрания Российской Федерации» // Ведомости Федерального Собрания. 1999. № 26. 11 сентября.

52. Постановление Правительства Российской Федерации от 13 января 2000 года № 32 «О содействии избирательным комиссиям в организации подготовки и проведения выборов Президента Российской Федерации» // Рос. газ. 2000. 13 января.

53. Постановление Правительства Российской Федерации от 2 июля 2003 г. № 391 «О порядке выдачи гражданам Россииской Федерации, находящимся в местах содержания под стражей подозреваемых и обвиняемых, справки для участия в выборах или в референдуме» // СЗ РФ. 2003. № 27 (ч. 2). Ст. 2812. 
54. Постановление Правительства Российской Федерации от 5 сентября 2003 года № 555 «О мерах по содействию избирательным комиссиям в организации подготовки и проведения выборов депутатов Государственной Думы Федерального Собрания Российской Федерации и Президента Российской Федерации» // С3 РФ. 2003. № 37. Ст. 3596.

55. Постановление Правительства Российской Федерации от 17 сентября 2007 года № 589 «О мерах по оказанию содействия избирательным комиссиям в реализации их полномочий при подготовке и проведении выборов депутатов Государственной Думы Федерального Собрания Российской Федерации и Президента Российской Федерации» // Рос. газ. 2007. 26 сентября.

56. Постановление Правительства Российской Федерации от 29 июня 2011 года № 511 «О мерах по оказанию содействия избирательным комиссиям в реализации их полномочий при подготовке и проведении выборов депутатов Государственной Думы Федерального Собрания Российской Федерации шестого созыва и выборов Президента Россииской Федерации» // С3 РФ. 2011. № 28. Ст. 4209.

\section{Постановления Центральной избирательной комиссии Российской Федераичии}

57. Постановление Центральной избирательной комиссии Российской Федерации от 30 ноября 2001 г. № 144/1320-3 «О содействии Центральной избирательной комиссии, органов исполнительной власти, правоохранительных органов избирательным комиссиям субъектов Российской Федерации в организации проведения выборов» // Вестник ЦИК Российской Федерации. 2001. № 10. C. 10-12.

58. Постановление Центральной избирательной комиссии Российской Федерации от 25 апреля 2007 г. (в ред. от 19 ноября 2008 г.) № 5/45-5 «О Положении о Контрольно-ревизионной службе при Центральной избирательной комиссии Российской Федерации» // Вестник ЦИК Российской Федерации. 2007. № 5; 2008. № 12 .

59. Постановление ЦИК России от 24 ноября 2010 г. № 228/1503-5 «Об утверждении Порядка проведения антикоррупционной экспертизы нормативных правовых актов и проектов нормативных правовых актов в Центральной избирательной комиссии Россииской Федерации» // Вестник Центральной избирательной комиссии Российской Федерации. 2010. № 11.

\section{Нормативные правовые акты министерств и ведомств Российской Федераичии}

60. Приказ Генеральной прокуратуры Российской Федерации, МВД России, ФСБ России, ДНП России от 22 мая 1995 г. № 32/199/73/278 «Об утверждении Положения о совместных следственно-оперативных группах (бригадах) органов прокуратуры, внутренних дел, безопасности и налоговой полиции для пресечения и расследования деятельности организованных преступных групп» [Текст приказа не опубликован.]

61. Приказ Министра внутренних дел Российской Федерации от 21 февраля 2005 г. № 108 «Об объявлении Соглашения о взаимодействии Центральной избирательной комиссии Российской Федерации и Министерства внутренних дел Российской Федерации». [Текст приказа не опубликован.] 
62. Приказ Министра внутренних дел Российской Федерации от 26 сентября 2007 г. № 835 «О порядке исполнения органами внутренних дел Россииской Федерации представлений избирательных комиссий» [Текст приказа не опубликован.]

63. Приказ Федеральной налоговой службы от 10 августа 2007 г. № ММ-3-04/474 «Об организации работы по оказанию содействия Центральной избирательной комиссии Российской Федерации в проверке достоверности сведений о размере и об источниках доходов, имуществе, принадлежащем кандидату на праве собственности, о вкладах в банках, ценных бумагах, представляемых кандидатами в депутаты Государственной Думы Федерального Собрания Российской Федерации пятого созыва». [Текст приказа не опубликован.]

64. Приказ МВД России от 7 ноября 2011 г. № 1121 «Об утверждении Административного регламента Министерства внутренних дел Российской Федерации по предоставлению государственной услуги по выдаче справок о наличии (отсутствии) судимости и (или) факта уголовного преследования либо о прекращении уголовного преследования» [Текст приказа не опубликован.]

\section{Нормативные правовые акты иностранных государств}

65. Strafgesetzbuch (StGB) in der Fassung der Bekanntmachung vom 13. November 1998 // BGB1. I S. 3322.

66. Strafprozessordnung (StPO) in der Fassung der Bekanntmachung vom 7. April 1987 // BGBl. I S. 1074, 1319.

67. Gesetz zur Harmonisierung des Schutzes gefaehrdeter Zeugen (Zeugenschutz-Harmonisierungsgesetz vom 11. December 2001 - ZSHG // BGB1. I S. 3510 .

68. Gesetz zur Regelung des Statusrechts der Beamtinnen und Beamten in den Laendern (Beamtenstatusgesetz vom 17. Juni 2008) // BGBl. I S. 1010.

\section{Судебная практика}

Постановления Европейского суда по правам человека

69. Постановление Европейского Суда по правам человека от 2 марта 1987 г. по делу «Матье-Моэн (Mathieu-Mohin) и Клерфейт (Clerfayt) против Бельгии» // Европейский Суд по правам человека. Избранные решения: в 2 т. М.: Норма, 2000 .

70. Постановление Европейского Суда по правам человека от 5 ноября 2002 г. по делу «Алан против Соединенного Королевства» (Allan-United Kingdom) (№ 48539/99) // Бюллетень Европейского Суда по правам человека. Российское издание. 2003. № 4.

71. Постановление Европейского суда по правам человека от 30 марта 2004 г. «Дело Херст (Hirst) против Соединенного Королевства» // Международные избирательные стандарты. Сб. документов. М.: Издательство Весь Мир, 2004. С. 738-741.

72. Постановление Европейского Суда по правам человека от 6 февраля 2007 г. по делу «Дойл (Doyle) против Соединенного Королевства» // Бюллетень Европейского Суда по правам человека. Российское издание. 2007. № 8. 
73. Постановление Европейского суда по правам человека от 10 марта 2009 г. «Дело Быков (Bykov) против Российской Федерации» (жалоба № 4378/02) // Бюллетень Европейского Суда по правам человека. Российское издание. 2009. № 6.

\section{Судебные постановления судов общей юрисдикиии Российской Федеращии (CСCP)}

74. Постановление Пленума Верховного Суда СССР от 18 марта 1970 г. № 4 «Об исчислении срока погашения судимости» // Сб. постановлений Пленума Верховного Суда СССР 1924-1977. Ч.2. М.: Известия, 1978.

75. Постановление Пленума Верховного Суда СССР от 21 сентября 1977 г. № 11 «Об изменении и дополнении постановления Пленума Верховного Суда СССР от 18 марта 1970 г. № 4 «Об исчислении срока погашения судимости». [Текст не опубликован.]

76. Определение Судебной коллегии по гражданским делам Верховного Суда Российской Федерации от 9 марта 2006 г. № 1-ГО6-9 по кассационной жалобе Тутова А.Н. на решение Архангельского областного суда от 22 февраля 2006 года, которым отказано в удовлетворении его заявления об отмене постановления окружной избирательной комиссии по одномандатному избирательному округу N 3 об отказе в его регистрации кандидатом в депутаты Архангельского областного Собрания депутатов.

77. Постановление Пленума Верховного Суда Российской Федерации от 10 июня 2010 г. № 2 «О судебной практике рассмотрения уголовных дел об организации преступного сообщества (преступной организации) или участии в нем (ней)» // Рос. газ. 2010. 17 июня.

78. Постановление Пленума Верховного Суда Российской Федерации от 31 марта 2011 г. № 5 «О практике рассмотрения судами дел о защите избирательных прав и права на участие в референдуме граждан Российской Федерации» // Рос. газ. 2011.8 апреля.

\section{Литература}

79. Волков В.П., Дамаскин О.В., Шапиев С.М. Некоторые проблемы и пути их решения для обеспечения законности избирательного процесса в Российской Федерации. М.: РЦОИТ, 2009. 288 с.

80. Выборы в Российской Федерации. 2007. Электоральная статистика / Центральная избирательная комиссия Российской Федерации. М.: СитиПрессСервис, 2008. 200 с.

81. Выборы Президента Российской Федерации. 2008: Сборник информационно-аналитических материалов / Центральная избирательная комиссия Российской Федерации. М.: СитиПрессСервис, 2008. 328 с.

82. Выборы в субъектах Российской Федерации 2 марта 2008 года и в единые дни голосования 12 октября 2008 года, 1 марта 2009 года: Электоральная статистика. М.: ЦИК России, 2009. 228 с.

83. Выборы в субъектах Российской Федерации в единый день голосования 14 марта 2010 года: Электоральная статистика. М.: ЦИК России, 2010. $152 \mathrm{c}$.

84. Выборы в субъектах Российской Федерации в единый день голосования 10 октября 2010 года: Электоральная статистика. М.: ЦИК России, 2011. 148 c. 
85. Галактионов E.A. Уголовно-правовые средства борьбы с организованной преступностью : Дис. ... канд. юрид. наук. М., 1993.

86. Дамаскин О.В., Красинский В.В., Сеченова Р.Р., Фахретдинова А.И. Прокуратура в системе обеспечения конституционной законности избирательного процесса в интересах безопасности государственного строительства. Научно-методическое пособие. М.: НИИ проблем укрепления законности и правопорядка при Генеральной прокуратуре РФ, 2005. 82 с.

87. Дамаскин О.В. Российская Армия в современном обществе: проблемы и перспективы. М.: Юрлитинформ, 2011.

88. Дамаскин О.В. Коррупция: состояние, причины, противодействие. М.: Триумфальная арка, 2009. 321 с.

89. Дамм И.А. Коррупция в российском избирательном процессе: понятие и противодействие. Автореф. дис. ... канд. юрид. наук. Красноярск, 2006. C. 15.

90. Доклад Уполномоченного по правам человека в Российской Федерации за 2012 год. М., 2013. 180 с.

91. Жбанков B.A. К вопросу изучения личности руководителей организованных преступных формирований / Проблемы техникокриминалистического раскрытия и расследования преступлений: Мат. науч.практ. конф. М.: МЮИ МВД России, 1997. С. 137-139.

92. Злотникова E.B. Влияние организованной преступности на политическую безопасность Российской Федерации. Автореф. ...канд. полит. наук. М., 2011.

93. Зорькин В.Д. Угрозы международной и национальной безопасности и ограничение прав человека в практике конституционного правосудия // Российское правосудие. 2006. № 2. С. 3-13.

94. Зорькин В.Д. Об угрозах конституционного строя в XXI веке и необходимости проведения правовой реформы в России // Журнал российского права. 2004. № 6. С. 3-17. декабря.

95. Зорькин В.Д. Конституция против криминала // Рос. газ. 2010. 10

96. Избирательное законодательство и выборы в современном мире / В.И. Лысенко, А.Г. Головин. М.: МедиаПресс, 2009. 528 с.

97. Избирательное законодательство и выборы в современном мире / В.И. Лысенко. М.: МедиаПресс, 2010. 863 с.

98. Кабанов П.А., Райков Г.И., Чирков Д.К. Политическая коррупция в условиях реформирования российской государственности на рубеже веков: Монография. М.: Дружба народов, 2008.

99. Комментарий к Конституции Российской Федерации / Под ред. В.Д. Зорькина, Л.В. Лазарева. М.: Эксмо, 2009. 1056 с.

100. Красинский B.B. Проблемы борьбы с криминалитетом в ходе избирательных кампаний // Юридический мир. 2003. № 9. С. 4-8.

101. Красинский B.B. Участие организованных преступных групп в избирательных кампаниях // Политика и общество. 2008. № 4. С. 7-13.

102. Красинский В.В. Правовое обеспечение защиты конституционного строя России в избирательном процессе. Монография. М.: Новый индекс, 2010. 340 с.

103. Красинский B.B. Преступные организации (сообщества) как элемент политической системы российского общества // Человеческий капитал. 2011. № 1. 
104. Куфельд В. Вхождение криминала во власть // Независимая газета. 1998. 14 ноября.

105. Мохов E.A. Организованная преступность и национальная безопасность России. М.: Вузовская книга, 2006.

106. Мохов E.A. ФСБ: борьба с организованной преступностью. М.: Вузовская книга, 2006. 316 с.

107. Научно-практический комментарий к Федеральному закону «Об основных гарантиях избирательных прав и права на участие в референдуме граждан Российской Федерации» / Отв. ред. канд. юрид. наук А.А. Вешняков; науч. ред. доктор юрид. наук В.И. Лысенко. М.: Объединенная редакция МВД России, 2007. 861 с.

108. Научно-практический комментарий к Федеральному закону «О выборах депутатов Государственной Думы Федерального Собрания Российской Федерации»/// Отв. ред. канд. юрид. наук А.А. Вешняков; науч. ред. доктор юрид. наук В.И. Лысенко. М., 2007. 784 с.

109. Неронов И. К вопросу о проверке избирательной комиссией наличия у кандидатов пассивного избирательного права в свете изменения законодательства // О выборах. 2012 . № 5. С 37.

110. Никитина М. Коррупционная дюжина // Рос. газ. 2007. 7 декабря.

111. Полунин $A$. «Братки» собрались во власть // Труд. 2004. 10 августа.

112. Рекомендуемые виды практики в области защиты свидетелей при производстве по уголовным делам, касающимся организованной преступности. Управление ООН по наркотикам и преступности. Нью-Иорк, 2008. C.22 // URL: http://sartraccc.ru/Pub inter/protwitn.pdf (дата обращения: 4 сентября 2013 г.).

113. Сведения о размере и об источниках доходов, имуществе, принадлежащем кандидатам на праве собственности, о вкладах в банках, ценных бумагах (на основании данных, представленных кандидатами) // Рос. газ. 2007. 2 декабря.

114. Сведения о размере и об источниках доходов, имуществе, принадлежащем кандидатам на праве собственности, о вкладах в банках, ценных бумагах (на основании данных, представленных кандидатами) // Рос. газ. 2011. 4 декабря.

115. Современные избирательные системы. Вып. 1: Великобритания, Канада, Мексика, Польша. М.: Норма, 2006. 495 с.

116. Современные избирательные системы. Вып. 2: Аргентина, Германия, Швеция. М.: РЦОИТ: Норма, 2007. 319 с.

117. Современные избирательные системы. Вып. 3: Испания, США, Финляндия, Япония. М.: РЦОИТ: Новости, 2009. 448 с.

118. Современные избирательные системы. Вып. 4: Австралия, Венесуэла, Дания, Сербия. М.: РЦОИТ: Ин-октаво, 2009. 480 с.

119. Современные избирательные системы. Вып. 5: Индия, Ирак, Уругвай, ЮАР. М.: РЦОИТ, 2010. 496 с.

120. Состояние законности и правопорядка в Российской Федерации и работа органов прокуратуры. 2012 год: информационно-аналитическая записка под общ. ред. ректора Академии Генеральной прокуратуры Российской Федерации д-ра юрид. наук, проф. О.С. Капинус. М., 2013. 343 с.

121. Copых B.M. Теория государства и права: Учебник. М.: Юридический Дом «Юстицинформ», 2001.

122. Теория государства и права: Учебник / Под ред. О.В. Мартышина. М.: Норма, 2007. С. 183. 
123. Федеральные списки кандидатов в депутаты Государственной Думы Федерального Собрания Российской Федерации шестого созыва, выдвинутые политическими партиями и зарегистрированные Центральной избирательной комиссией Российской Федерации. Специальный информационный выпуск ЦИК РФ // Рос. газ. 2011. 4 декабря. 200 с.

124. Франскевич М.П., Щедрин Н.В. Криминальное прошлое как основание ограничения пассивного избирательного права / Актуальные проблемы борьбы с преступностью в Сибирском регионе. Сб. материалов Международной научно-практической конференции. Ч.1. Красноярск, 2005. C. 300-303. $5(2135)$.

125. Ходки политика Климентьева // Коммерсантъ. 2001. 16 января. № 
ПРИЛОЖЕНИЯ

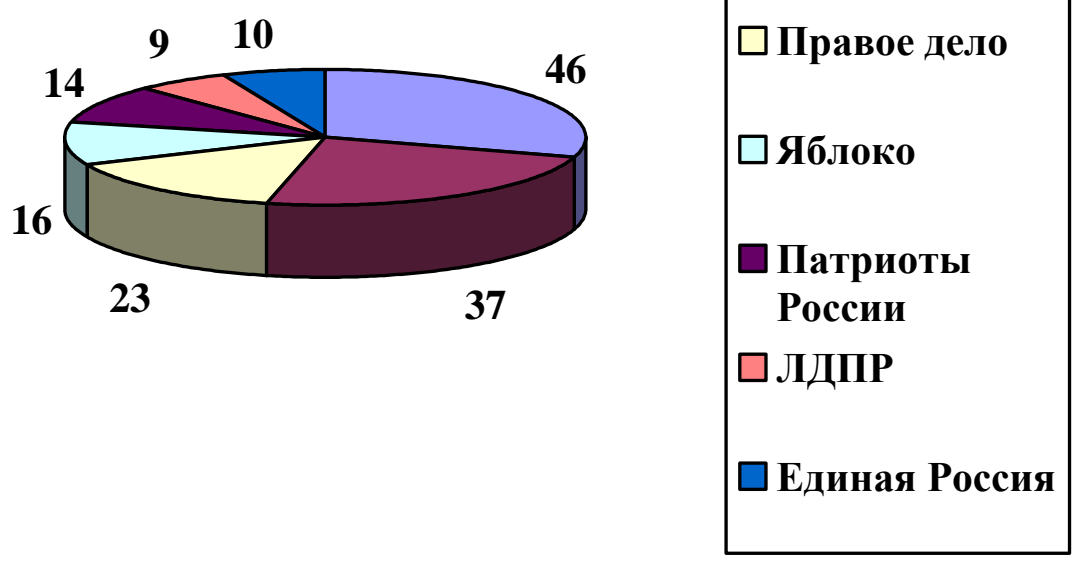

$\square$ Справедливая Россия

$\square$ КПРФ

$\square$ Правое дело

$\square$ Яблоко

Патриоты

России

$\square$ ЛДПР

$\square$ Единая Россия

Приложение 1. Количество кандидатов, привлекавшихся к уголовной ответственности, в зарегистрированных списках кандидатов в депутаты Государственной Думы Федерального Собрания Российской Федерации шестого созыва 


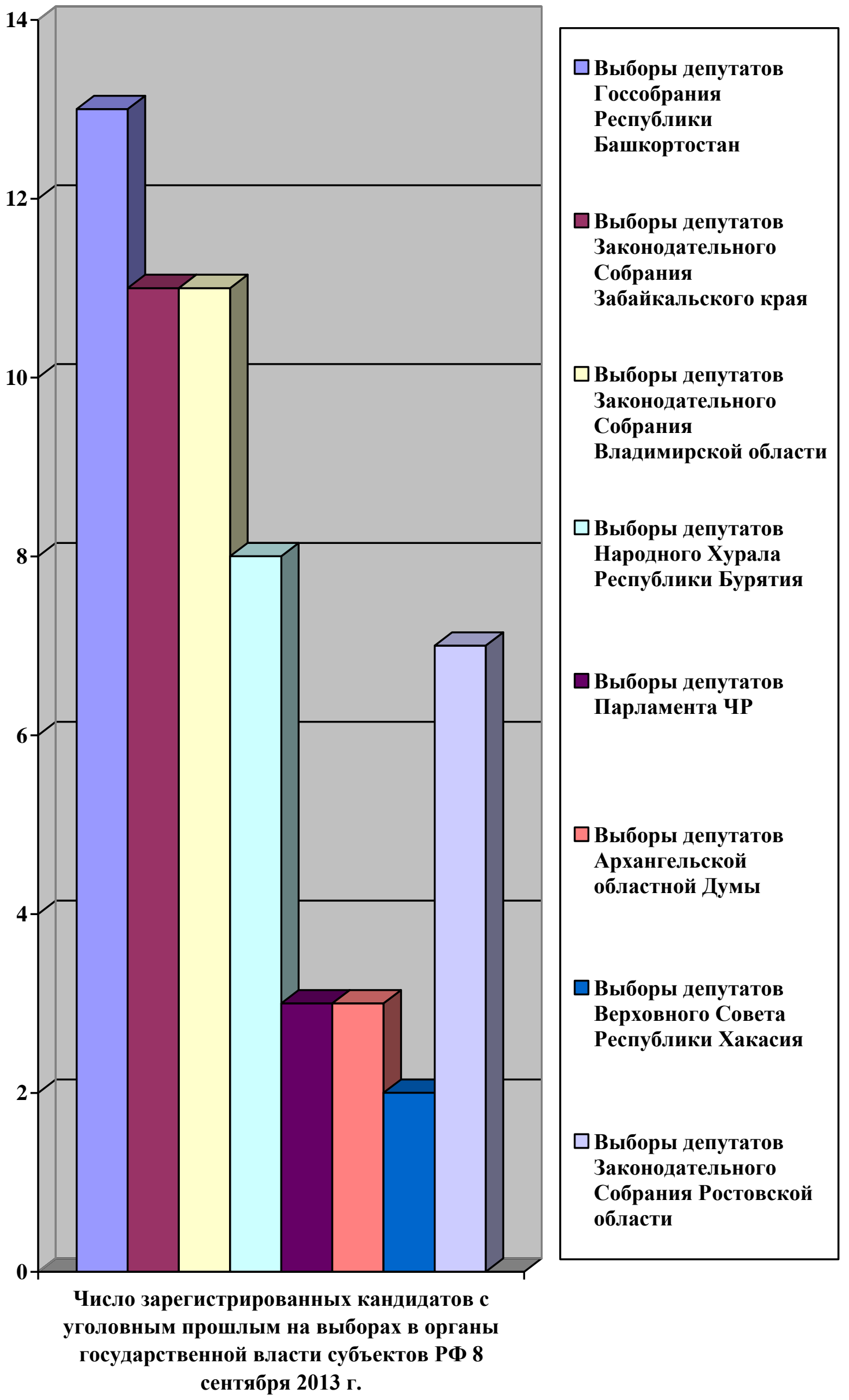




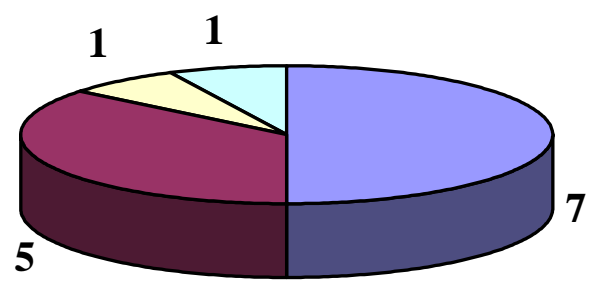

\begin{tabular}{|l|}
\hline$\square$ Выборы \\
депутатов \\
Екатеринбургск \\
ой городской \\
Думы \\
$\square$ Выборы \\
депутатов \\
Волгоградской \\
городской Думы \\
\\
$\square$ Выборы \\
депутатов \\
Архангелькой \\
городской Думы \\
\\
$\square$ Выборы \\
депутатов \\
Красноярского \\
городского \\
Совета
\end{tabular}

Приложение 3. Количество зарегистрированных кандидатов, привлекавшихся к уголовной ответственности, на выборах в органы местного самоуправления административных центров субъектов Российской Федерации 8 сентября 2013 г. 


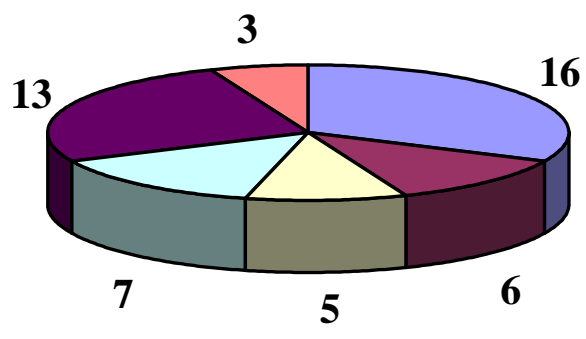

\begin{tabular}{|l|}
\hline Справедливая \\
Россия \\
$\square$ КПРФ \\
$\square$ Яблоко \\
$\square$ Патриоты \\
России \\
ЛДПР \\
$\square$ Единая Россия
\end{tabular}

Приложение 4. Количество кандидатов - представителей парламентских партий, привлекавшихся к уголовной ответственности, на выборах в органы государственной власти субъектов Российской Федерации и органы местного самоуправления административных центров субъектов Российской Федерации 8 сентября 2013 г. 


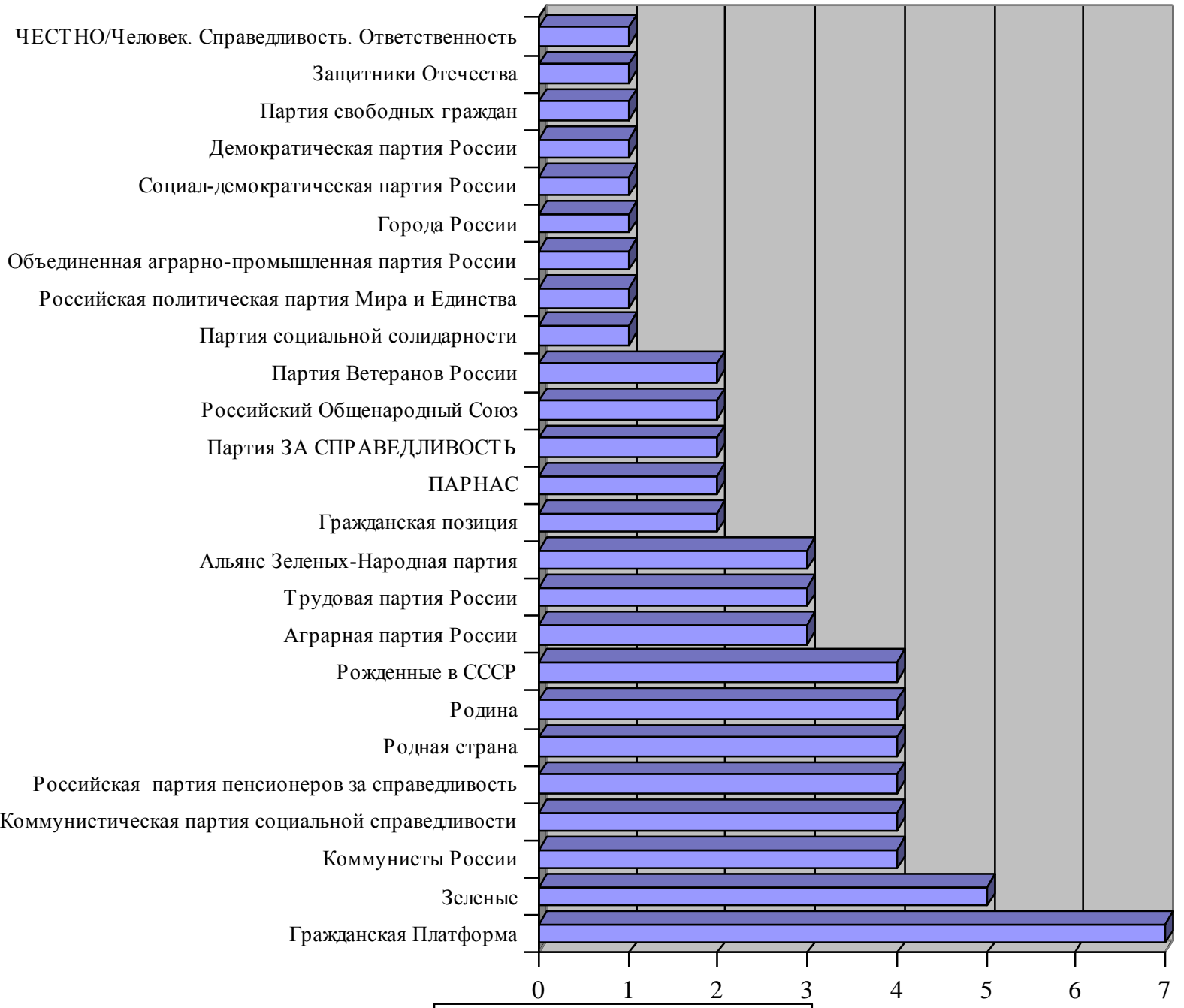

$\square$ Приложение 5. Количество кандидатов - представителей непарламентских партий, привлекавшихся к уголовной ответственности, на выборах 8 сентября 2013 г. 
Преступления против интересов службы в коммерческих и иных организациях

Преступления против семьи и несовершеннолетних

Преступления против безопасности движения и эксплуатации транспорта

Преступления против здоровья населения и общественной нравственности

Преступления против порядка управления

Преступления в сфере экономической деятельности

Преступления против государственной власти

Преступления против жизни и здоровья

Преступления против общественной безопасности

Преступления против собственности

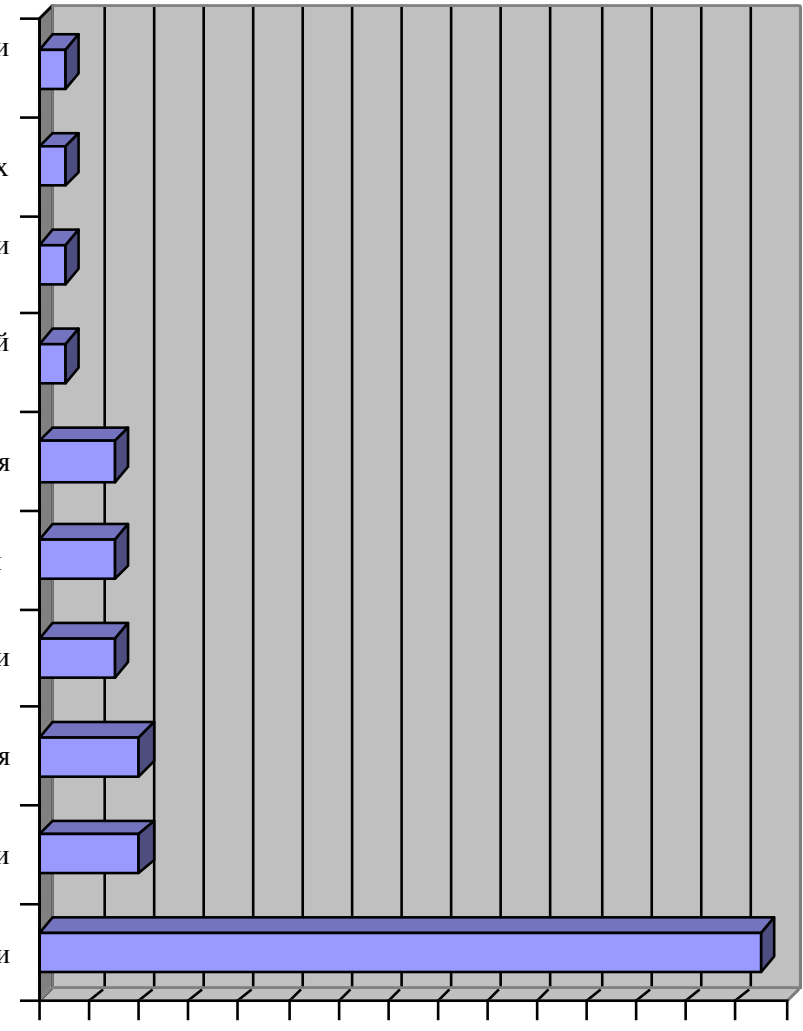

024681012141618202224262830

$\square$ Приложение 6. Распределение осужденных по составам преступлений в зарегистрированных списках парламентских партий на выборах 8 сентября 2013 г. 


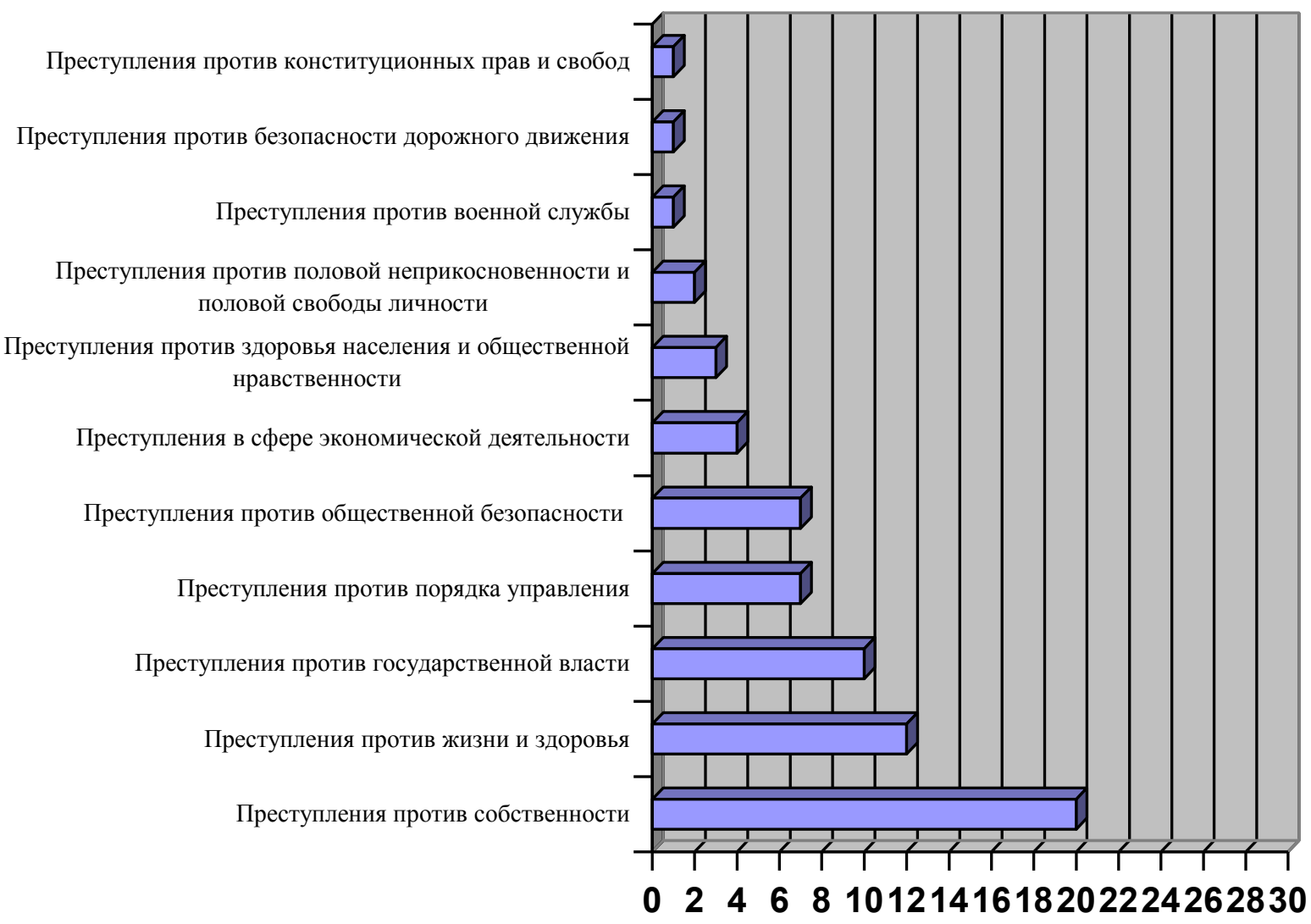

Приложение 7. Распределение осужденных по составам преступлений в зарегистрированных списках непарламентских партий на выборах 8 сентября 2013 г. 


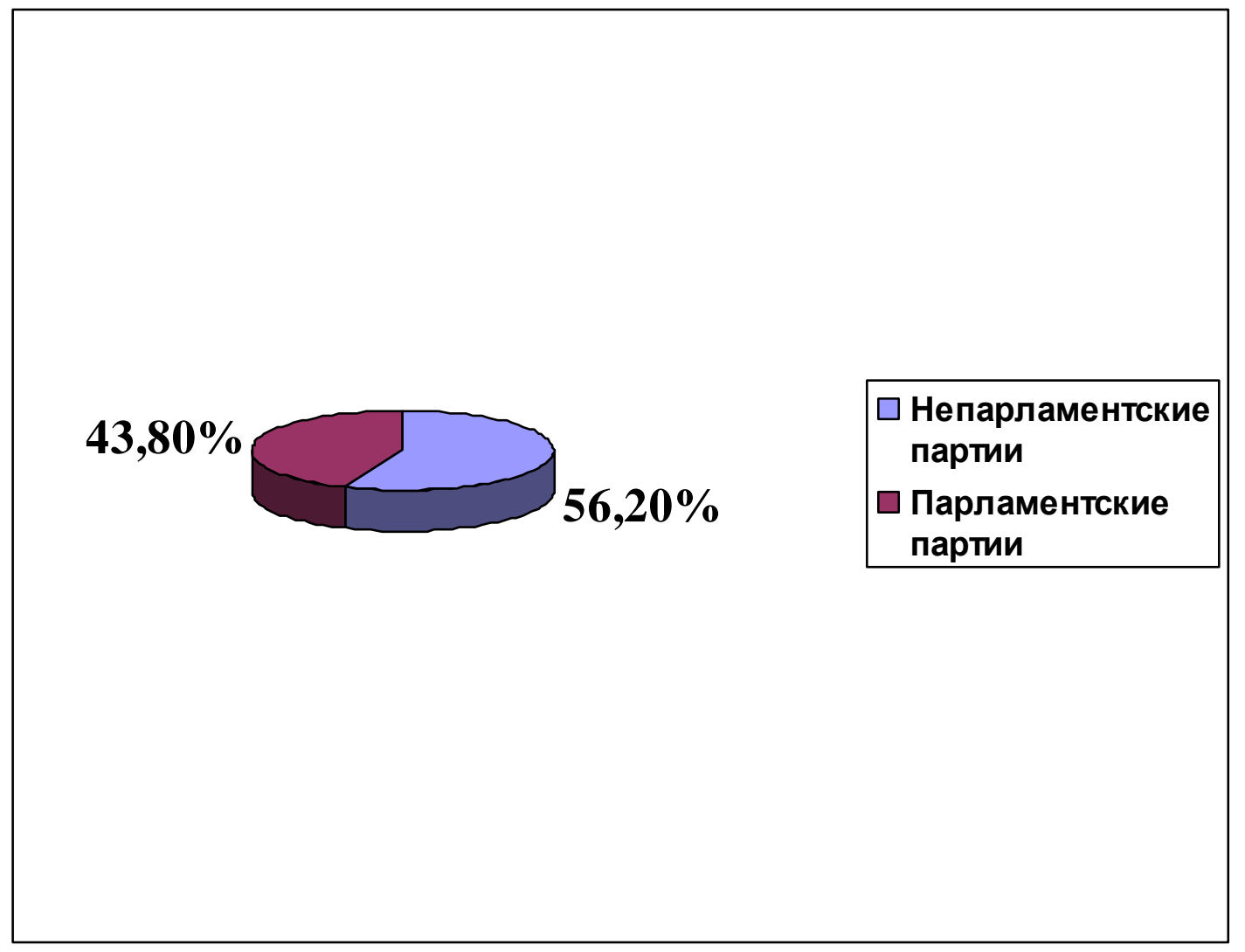

Приложение 8. Процентное соотношение кандидатов - представителей парламентских и непарламентских партий, привлекавшихся к уголовной ответственности, на выборах в органы государственной власти субъектов Российской Федерации и органы местного самоуправления административных центров субъектов Российской Федерации 8 сентября 2013 г. 